DEPARTMENT OF THE INTERIOR UNITED STATES GEOLOGICAL SURVEY

\author{
MAJOR RESULTS OF GEOPHYSICAL INVESTIGATIONS \\ AT YUCCA MOUNTAIN AND VICINITY, SOUTHERN NEVADA
}
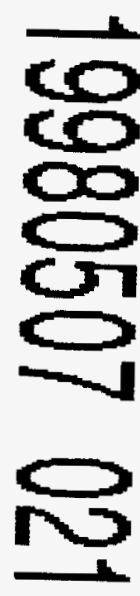

H.W. Oliver, D.A. Ponce, and W. Clay Hunter, Editors

1995

RECEIVED

APR 221998

OSTI

Open-File Report 95-74

\author{
Prepared in cooperation with the \\ Nevada Operations Office \\ U.S. Department of Energy \\ (Interagency Agreement DE-AI08-92NV10874)
}

This report is preliminary and has not been reviewed for conformity with U.S. Geological Survey editorial standards or with the North American Stratigraphic Code. Any use of trade, firm, or product names is for descriptive purposes only and does not imply endorsement by the U.S. Government.

Menlo Park, California

EMTAIBUTION OF THIS DOCUMENT IS UNLIMTTED

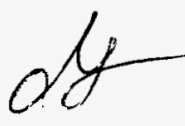


DEPARTMENT OF THE INTERIOR

U.S. GEOLOGICAL SURVEY

\title{
MAJOR RESULTS OF GEOPHYSICAL INVESTIGATIONS AT YUCCA MOUNTAIN AND VICINITY, SOUTHERN NEVADA
}

\author{
H.W. Oliver ${ }^{1}$, D.A. Ponce ${ }^{1}$, and W. Clay Hunter ${ }^{2}$ \\ Editors
}

U.S. Geological Survey Open-File Report 95-74

lUSGS, 345 Middlefield Road, M/S 977, Menlo Park, CA 94025

2USGS, Yucca Mountain Project Branch, Box 25046, M/S 421, Denver Federal Center, Denver, CO 80225

This report is preliminary and has not been edited for conformity with U.S. Geological Survey editorial standards and stratigraphic nomenclature. Any use of brand names is for descriptive purposes only and does not imply endorsement by the U.S. Geological Survey.

Menlo Park, California 1995 


\section{U.S. DEPARTMENT OF THE INTERIOR BRUCE BABBITT, Secretary \\ U.S. Geological Survey \\ Gordon P. Eaton, Director}

The use of trade, product, industry, or firm names is for descriptive purposes only and does not imply endorsement by the U.S. Government.

For additional information, write to:

Chief, Earth Sciences Investigation Program

Yucca Mountain Project Branch

U.S. Geological Survey

Box 25046, Mail Stop 42I

Denver Federal Center

Denver, CO 80225
Copies of this report can be purchased from:

U.S. Geological Survey

Earth Science Information Center

Open-File Reports Section

Box 25286, Mail Stop 517

Denver Federal Center

Denver, CO 80225 


\section{CONTENTS}

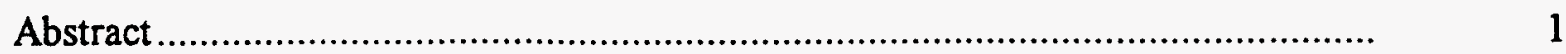

Chapter 1. Introduction and geologic setting ...................................... Oliver

Chapter 2. Gravity investigations.

D.A. Ponce and H.W. Oliver

Chapter 3. Magnetic investigations. H.W. Oliver, D.A. Ponce, and H.R. Blank

Chapter 4. Regional magnetotelluric investigations Douglas P. Klein

Chapter 5. Seismic refraction investigations. Walter D. Mooney and Scott Schapper

Chapter 6. Seismic reflection investigations. Thomas M. Brocher

Chapter 7. Teleseismic investigations John R. Evans and Moses Smith III

Chapter 8. Regional thermal setting. J.H. Sass W.W. Dudley, Jr. and Arthur H. Lachenbruch

Chapter 9. Stress measurements John H. Healy

Chapter 10. Integration of methods and conclusions H.W. Oliver and E.L. Hardin

\section{TABLES}

Table 1.1. Physical Properties of Rocks in the Vicinity of Yucca Mountain.

Table 9.1. Stress Measurements and Calculated Parameters in Drill Hole USW G-1 


\section{ILLUSTRATIONS}

Figure 1.1. Location map showing the Yucca Mountain site, southern Nevada.......... 10

Figure 1.2. Terrain map showing elevations in the southern Great Basin................... 11

Figure 1.3. Location map showing weapons-testing and potential storage areas on the Nevada Test Site

Figure 1.4. Location map showing the potential repository site at Yucca Mountain.... 13

Figure 1.5. Generalized geologic map of the southern Great Basin........................... 15

Figure 1.6. Location map showing Quaternary faults and earthquake epicenters near Yucca Mountain....................................................................... 16

Figure 1.7. Generalized geologic map of the Crater Flat-Yucca Mountain area.......... 18

Figure 1.8. Schematic geologic cross sections across Crater Flat.............................. 22

Figure 2.1. Map showing complete Bouguer gravity of the southern Great Basin...... 37

Figure 2.2. Map showing isostatic residual gravity of the southern Great Basin......... 39

Figure 2.3. Location map of the Yucca Mountain area showing gravity stations........ 40

Figure 2.4. Simplified geologic map of the Beatty, Nevada, quadrangle showing gravity profile A-A'.

Figure 2.5. Schematic diagram showing isostatic gravity residuals and a detachment model of structure beneath Yucca Mountain....................................... 43

Figure 2.6. Index map showing gravity profiles across Fortymile Wash..................... 45

Figure 2.7. Gravity and topographic profiles across Fortymile Wash....................... 46

Figure 3.1. Map showing residual total magnetic anomalies of the southern Great Basin.

Figure 3.2. Aeromagnetic index map of the Yucca Mountain region showing flight-line spacing of available data................................................... 58

Figure 3.3. Total intensity aeromagnetic map of Yucca Mountain and vicinity........... 59

Figure 3.4. Aeromagnetic map of the Crater Flat area................................................... 62

Figure 3.5. Aeromagnetic map of the Lathrop Wells area......................................... 63

Figure 3.6. Schematic cross section showing theoretical magnetic anomalies for total effect of fault-offset volcanic rocks............................................ 64

Figure 3.7. Index map showing locations of gravity and magnetic profiles................. 66

Figure 4.1. Location map showing magnetotelluric traverses near the Nevada Test Site 74

Figure 4.2. Examples of magnetotelluric sounding curves...................................... $\quad 76$

Figure 4.3. Location map showing magnetotelluric soundings in southern Nevada...... 81

Figure 4.4. Location map showing magnetotelluric soundings acquired in 1986 in the Yucca Mountain region........................................................... 83

Figure 4.5(a). Location map showing deep electrical soundings across the Walker Lane structural belt of southern Nevada.

Figure 4.5(b). Comparison of composite one-dimensional models of deep electrical soundings across the Walker Lane structural belt

Figure 4.6. Preliminary two-dimensional resistivity model across the Yucca Mountain vicinity... 
Figure 5.1. Location map showing seismic refraction profiles in the Yucca Mountain

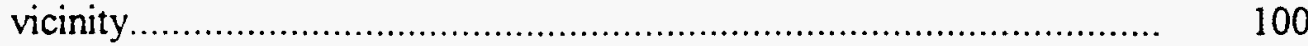

Figure 5.2. Isostatic residual gravity map of the Yucca Mountain area showing locations of refraction profiles........................................................ 102

Figure 5.3. Crustal velocity section along the Yucca Mountain profile........................ 103

Figure 5.4. Crustal velocity section along the Crater Flat profile................................ 107

Figure 5.5. Crustal velocity section along the Beatty profile....................................... 108

Figure 5.6. Crustal velocity section along the Fortymile Wash profile......................... 110

Figure 5.7. Crustal velocity section along the Amargosa profile................................ 112

Figure 5.8. Velocity section along the Beatty profile showing the inferred location of Tertiary detachment faults....................................................... $\quad 115$

Figure 6.1. Location map showing existing and proposed deep seismic reflection surveys in the Yucca Mountain vicinity ........................................... 124

Figure 6.2. Comparison of seismic reflection records using explosive and vibrator

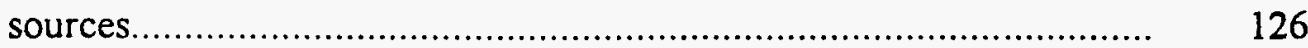

Figure 6.3. Relative-amplification seismic reflection section along part of line AV-1... 127

Figure 6.4. Unmigrated explosive-source reflection section along part of line AV-1... 128

Figure 6.5 Map of the vicinity of Yucca Mountain showing location of regional seismic lines 2 and 3

Figure 7.1(a). Location map showing geographic setting, cross section lines, and seismograph stations in the southern Great Basin..

Figure 7.1(b). Location map showing geographic setting, cross section lines, and seismograph stations in the Nevada Test Site and vicinity.................. 137

Figure 7.2. Histogram showing phase pick accuracy............................................... 141

Figure 7.3(a). Tomographic inversion results for a part of the southern Great Basin... 142

Figure 7.3(b). Tomographic inversion results for cross section B-B'........................ 143

Figure 7.3(c). Tomographic inversion results for cross section C-C'........................ 144

Figure 7.4(a). Unstripped and inverted velocity model from the surface layer in the vicinity of the Nevada Test Site............................................................ 145

Figure 7.4(b). Unstripped cross section showing velocity results for section A-A'...... 146

Figure 7.4(c). Stripped cross section showing velocity results for section A-A'.......... 147

Figure 7.4(d). Unstripped cross section showing velocity results for section C-C'...... 148

Figure 7.4(e). Stripped cross section showing velocity results for section C-C'.......... 149

Figure 8.1. Distribution of heat flow in the western United States............................. 158

Figure 8.2. Configuration of the $60 \mathrm{~mW} \mathrm{~m}^{-2}$ heat-flow contour in the vicinity of the Nevada Test Site.

Figure 8.3. Conductive heat flow from the unsaturated zone in the vicinity of Yucca Mountain

Figure 8.4. Temperature of the water table in the vicinity of Yucca Mountain............ 163

Figure 8.5. Temperature profiles from the saturated zone in drill holes UE-25 p\#1

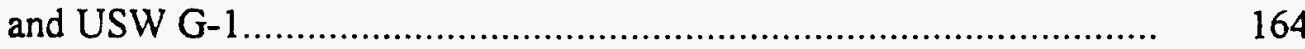

Figure 8.6. Temperature profiles in the vicinity of Crater Flat.................................... 168

Figure 9.1. Stress data from borehole USW G-1................................................. 176 


\title{
MAJOR RESULTS OF GEOPHYSICAL INVESTIGATIONS AT YUCCA \\ MOUNTAIN AND VICINITY, SOUTHERN NEVADA
}

\author{
H.W. Oliver, D.A. Ponce, and W. Clay Hunter, Editors
}

\begin{abstract}
On December 17, 1987, Congress named Yucca Mountain in southern Nevada as the only site in the United States to be characterized for long-term underground storage of high-level nuclear waste from nuclear power plants. Yucca Mountain is located about $110 \mathrm{~km}$ north of Las Vegas and is near the southwest corner of the Nevada Test Site. The potential storage area itself is located under the east-central part of Yucca Mountain. The so-called site area is a large area (12 by $18 \mathrm{~km}$ ) which includes hydrologic, geologic, and environmental study areas. In the consideration of Yucca Mountain as a possible site for storing high-level nuclear waste, a number of geologic concerns have been suggested for study by the National Academy of Sciences which include (1) natural geologic and geochemical barriers, (2) possible future fluctuations in the water table that might flood a mined underground repository, (3) tectonic stability, and (4) considerations of shaking such as might be caused by nearby earthquakes or possible volcanic eruptions.

This volume represents the third part of an overall plan of geophysical investigation of Yucca Mountain, preceded by the Site Characterization Plan (SCP; dated 1988) and the report referred to as the "Geophysical White Paper, Phase I," entitled Status of Data, Major Results, and Plans for Geophysical Activities, Yucca Mountain Project (Oliver and others, 1990). The SCP necessarily contained uncertainty about applicability and accuracy of methods then untried in the Yucca Mountain volcano-tectonic setting, and the White Paper, Phase I, focused on summarization of survey coverage, data quality, and applicability of results. For the most part, it did not present data or interpretation. The important distinction of the current volume ("Geophysical White Paper, Phase II") lies in presentation of data, results, and interpretations of selected geophysical methods used in characterization activities at Yucca Mountain, largely through 1990. Constraints of funding, scheduling, and applicability or availability of methods resulted in unavoidable variability of time frame of individual investigations. Separate chapters combined here were completed at various times over several years.
\end{abstract}

Yucca Mountain consists of a series of north-trending, eastward-tilted structural blocks bounded by steeply westward-dipping Cenozoic faults. These blocks consist of terrigenous volcanic and sedimentary rocks of Miocene age. The configuration of the base of the Tertiary section is poorly known as only one drill hole in the site area has reached the pre-Tertiary basement rocks. That hole (UE-25 p\#1) was intentionally drilled near a regional gravity high near the eastern edge of central Yucca Mountain and intersected Paleozoic dolomite at a depth of about $1.2 \mathrm{~km}$. Several other drill 
holes to the north and west within Yucca Mountain have penetrated up to $1.8 \mathrm{~km}$ of Tertiary rocks without reaching the Paleozoic basement rocks.

Some of the most important geologic questions that need to be answered are (1) the depth to, and nature of, the contact between the Cenozoic and Paleozoic rocks, (2) the origin and possible activity of the Quaternary faults, (3) the origin and stability of a rise of about $300 \mathrm{~m}$ in the potentiometric surface to the north of an approximate boundary of a potential repository, and (4) the possibility of future nearby volcanic activity. As the surface of Yucca Mountain is largely covered with Miocene volcanic flows assigned to the Tiva Canyon Tuff of the Paintbrush Group, geophysical methods and drilling are required to determine the subsurface structure and to answer these questions.

Gravity investigations began about 1979 at Yucca Mountain and immediately showed that Yucca Mountain does not have a basement core like so many ranges in Nevada. Rather, it is characterized by a gravity high at its east edge and a westward gravity decrease of about $20 \mathrm{mGal}$ (milligals) across Yucca Mountain to about $7 \mathrm{~km}$ inside Crater Flat. This gravity decrease has been modeled, and the models show a rather linear westward increase in the depth to Paleozoic basement rocks from about one to three or four $\mathrm{km}$ depending on the assumed density contrast between the Cenozoic volcanic rocks and the Paleozoic basement rocks. This westward drop-off in the basement rocks was initially interpreted as the edge of a caldera but has more recently been envisioned as a low-angle fault surface with a dip of about $10^{\circ}$ to the west. Farther west, gravity rises rapidly across Crater Flat by about $50 \mathrm{mGal}$ to the west edge of Bare Mountain where it levels out and stays rather flat across Bare Mountain. The curious observation is that the maximum gravity gradient occurs well out into Crater Flat and thus can't be modeled by a simple frontal fault at the edge of Bare Mountain. These data suggest the possibility of a significant basement downdrop to the east about $3 \mathrm{~km}$ west of the Bare Mountain front, although a significant facies change within the Cenozoic section could also explain the data.

Gravity investigations support additional conclusions about the setting of Yucca Mountain. North of Yucca Mountain, several circular gravity lows of up to $50 \mathrm{mGal}$ amplitude outline a series of calderas, the largest of which is the Timber Mountain Caldera. To the east, the gravity field drops only about $6 \mathrm{mGal}$ over Jackass Flats and stays rather constant for a distance of 15 to $20 \mathrm{~km}$. Thus, no significant structures apparently lie under Jackass Flats. More recently, the gravity method has become very helpful in locating and tracing north-striking concealed faults near the east side of Yucca Mountain and in Midway Valley where extensive surface facilities are planned.

Regional magnetic investigations of the Yucca Mountain area have been facilitated by the compilation of 39 aeromagnetic surveys in southern Nevada and 11 surveys in adjacent parts of California. The most important regional feature near Yucca Mountain is a magnetic high that extends from southeast to northwest over Wahmonie, the Calico Hills, and across the northern third of Yucca Mountain to the Prospector Pass caldera. This feature is associated with exposed Tertiary granitic rocks at Wahmonie and with altered magnetitebearing Paleozoic argillites in the Calico Hills. Thus, where the magnetic high crosses 
Yucca Mountain, it probably indicates a change in the basement rocks from the dolomite drilled under the east-central part of Yucca Mountain to some sort of granite, perhaps with some intervals enhanced by baked argillite. Depth analysis of the maximum gradient of the edge of the anomaly where it crosses Yucca Mountain indicates contact between magnetic and nonmagnetic basement at about $2.2 \mathrm{~km}$, and this is presently the only estimate of basement depth under the northern part of Yucca Mountain. This finding has important implications on structural and mineral assessment models of the area.

Several local dipolar magnetic anomalies have been found within Crater Flat and the nearby Amargosa Desert, and these may be caused by buried volcanic centers. The largest of these anomalies occurs just south of Lathrop Wells was drilled in 1991. Basalt was penetrated at a depth of $104 \mathrm{~m}$. Similarly, drilling near another nearby magnetic anomaly encountered basaltic cobbles at $183 \mathrm{~m}$. Thus, the magnetic method is apparently able to locate buried basaltic centers, and this information is making an important contribution to estimates of the probability of future volcanic activity in the region.

Both aeromagnetic and ground magnetic methods have also proven useful for locating concealed faults, because there are several layers within the tuffs that form the Paintbrush Group which have large remanent magnetizations, both normal and reversed. In the Yucca Mountain area, the expected signal from north-striking faults is a magnetic low to the west followed by a rise to the east of the fault of about double the magnitude of the western low. This model has been tested with airborne data which show that a 70-m-offset vertical fault displacement is required to produce a significant aeromagnetic anomaly. However, smaller displacements can be detected with ground magnetic data, and initial studies in Midway Valley and of the Ghost Dance fault indicate that the method can be very helpful for tracing concealed faults.

Another application of aeromagnetic data is the determination of the depth and structure of the Curie isotherm $\left(400^{\circ}\right.$ to $580^{\circ} \mathrm{C}$ depending on the amount of titanium in the magnetite). This temperature is reached at a depth of about $25 \mathrm{~km}$ under Yucca Mountain, but the isotherm structure is uncertain because of present limitations of data, particularly to the west in the Death Valley area. In southern Nevada, there is a good correlation between Curie isotherm depth greater than $25 \mathrm{~km}$ and low heat flow values north of Yucca Mountain.

Five magnetotelluric surveys were made from 1965 to 1986 in the region of Yucca Mountain. These surveys provide (1) comparative cross-sections across the Walker Lane (tectonic) belt southwest of Yucca Mountain (based on composited one-dimensional modeling), (2) a complementary cross section across the southern part of Yucca Mountain from Bare Mountain through part of Jackass Flats (based on 2-D modeling), and (3) tipper (vertical magnetic field) data that indicate a regional north-northwestern strike in electrically conductive faults, locally perturbed by conductive elements associated with caldera structures. Four main resistivity layers are found in the Yucca Mountain region, including (1) a ubiquitous, conductive, surface layer (10 to $30 \mathrm{ohm}-\mathrm{m}$ ) composed of alluvium or weathered rock outcrops; (2) variably shallow ( 2 to $12 \mathrm{~km}$ ), relatively conductive layers ( 30 
to $100 \mathrm{~m}$ in thickness) representing argillic sedimentary, or altered or thermally warmed, layers in more resistive rocks of diverse types; (3) a resistive basement (300 to $1000 \mathrm{ohm}-$ $\mathrm{m}$ ) of variable depth and thickness composed of plutonic and metamorphic rocks; and (4) a basal (deepest detected) low-resistivity zone (3 to $30 \mathrm{ohm}-\mathrm{m}$ ) of regional extent whose top appears roughly correlative with the base of the seismogenic zone at about 15 to $20 \mathrm{~km}$ depth. The resistivity and structure of supracrustal rocks (layer 2 above) at depths less than $12 \mathrm{~km}$ show considerable lateral variation. Magnetotelluric sections indicate that the Amargosa part of the Walker Lane belt appears to be a relatively resistive block that truncates elements of crustal layers found to the north. Magnetotelluric results also indicate a fault bounding the west side of Yucca Mountain that separates a thin ( 3 to $5 \mathrm{~km}$ ) section of supracrustal rocks (averaging $150 \mathrm{ohm}-\mathrm{m}$ ) on the east from a thicker (7 to $12 \mathrm{~km}$ ) section of similar-resistivity rocks to the west.

Interpretation of five seismic refraction profiles in the vicinity of Yucca Mountain defines the potential waste repository site as lying over complex extensional features manifested in the pre-Tertiary strata. Two of these seismic profiles were recorded, respectively, in 1983, in a north-south direction in Crater Flat; and in an east-west direction from northern Crater Flat to the Bullfrog Hills and Grapevine Mountains, west of Beatty, Nevada. Three additional profiles were recorded, in 1985, in an east-west direction across Yucca Mountain, in a north-south direction along Fortymile Wash, and in an east-west direction through the Amargosa Valley at the southern end of Yucca Mountain. The inferred preTertiary surface in the study area has a maximum depth of about $3.5 \mathrm{~km}$ beneath Crater Flat and forms an asymmetric, westward-deepening structure located between the east flank of Bare Mountain and as far east as eastern Yucca Mountain. The Tertiary volcanic section is $1.25 \mathrm{~km}$ thick beneath the eastern flank of Yucca Mountain at the latitude of the east-west seismic profile. It is unlikely that a single detachment surface has been active during the Cenozoic extension in this region. The modern detachment surface that accommodates fault movement observed at the surface on Yucca Mountain may coincide with the preTertiary contact beneath Crater Flat based on the geometry of some of the deep refracting horizons.

Several seismic reflection investigations have been conducted at Yucca Mountain, Mid Valley, and the Amargosa Desert. High-resolution seismic reflection profiles acquired across several faults in the vicinity of Yucca Mountain (including the Beatty scarp, Windy Wash fault, the Carpetbag fault, and the Ghost Dance fault) provide evidence that many of these faults are complex, contain multiple-strands, and form zones up to several hundred meters wide. Tests of the reflection method conducted in the Amargosa Desert indicate that vibrator methods can successfully map the crustal structure down to a depth of about 4 to $5 \mathrm{~s}$ two-way travel time (depths between 12 and $15 \mathrm{~km}$ ). These reflection data reveal the geometry and faulting of Tertiary sedimentary units within basins produced by Tertiary extension, as well as a nearly undeformed basaltic flow of late Miocene age near the top of the basins under the Amargosa Desert. In addition, the Amargosa reflection profile reveals discontinuous reflections from the pre-Tertiary basement rocks, which have been interpreted to represent potential Mesozoic thrust faults. Tests of explosion seismic sources in the Amargosa Desert provided clear images of the reflective lower crust beneath the 
Amargosa Desert and suggested that the top of this lower crustal sequence is shallower to the west, toward metamorphic core-complex exposures in the Funeral Mountains. Interpretations of the reflection data suggest that the crust is between 30 and $33 \mathrm{~km}$ thick under the Amargosa Desert. Reflection profiling in the vicinity of Yucca Mountain conducted in 1994 has helped to reveal the geometry of the pre-Tertiary/Tertiary contact under Crater Flat, Yucca Mountain and Jackass Flats, as well as the regional crustal structure in the Walker Lane belt.

Teleseismic tomography of compressional phases in the Yucca Mountain site area and region has been used to delineate any extant magma systems and to map tectonic structures that might affect a potential nuclear waste repository. An upper-mantle high-velocity anomaly has been interpreted beneath the Miocene Silent Canyon caldera. If this anomaly is related to volcanic activity in the Southwestern Nevada Volcanic Field, it may represent cooled residuum from the volume that once delivered heat to that system. Hence, the Southwestern Nevada Volcanic Field appears to be dead at its roots. A large volume of low-velocity upper mantle adjacent to this high may be any of several things, including partial melt. If it is the latter, it represents a large heat source for possible volcanism near the site area. The presence of large, mature, silicic magma chambers in the crust near Yucca Mountain can be ruled out, but a weak columnar low-velocity feature is present. This low-velocity object may be interpreted in various ways, one interpretation being local heating of the crust. Lastly, teleseismic tomography suggests that the eastern boundary of the Crater Flat depression falls very near or beneath the repository block and should be evaluated further.

Over most of the southwestern United States, heat flow is high, between 60 and $90 \mathrm{~mW}$ $\mathrm{m}^{-2}$ (milliwatt per square meter). There are significant areas of both higher and lower heat flow, however, and these heat-flow sources and sinks generally correspond to the tectonic history of the area under consideration. Yucca Mountain is located near the southern boundary of the "Eureka Low," a region of low heat flow ( $\left.<63 \mathrm{~mW} \mathrm{~m}^{-2}\right)$, which occupies much of east-central Nevada. From both deep temperature profiles and hydrologic studies, the primary cause of the low heat flow is thought to be interbasin water flow with a downward component of seepage velocity of a few millimeters per year. Measurements of heat flow near Yucca Mountain do not provide unambiguous indications of tectonic processes. In fact, within the area of the potential repository, the thermal regime appears to be dominated by water flow in the Paleozoic carbonate rocks underlying the Tertiary section. For this reason, the interpretation of existing shallow thermal data is more relevant to hydrologic characterization than to identification of tectonic hazards. Proposed deep holes at Yucca Mountain and Crater Flat might provide thermal data that bear on both tectonic and hydrologic investigations.

Stress measurements indicate that the present-day stress regime at Yucca Mountain is coupled to the extensional tectonics of the Basin and Range province. The present-day state of stress is consistent with recurrent movement on normal faults dipping about $60^{\circ}$ and striking about $\mathrm{N} 25^{\circ} \mathrm{E}$. The magnitude of shear stress on faults with this orientation is near the value required for faulting on preexisting faults. A modest increase in the shear stress or 
the fluid pressure therefore could cause movement on preexisting faults. The best set of stress data was obtained in drill hole USW G-1, where measurements between 646 meters and 1288 meters define a linear increase of the least horizontal stress with depth. This systematic linear increase of the magnitude of horizontal stress with depth suggests that this stress may reflect some failure mechanism. The dimensionless stress-parameters (vertical versus horizontal stress, shear versus normal stress, and orientation of the shear stress relation) associated with rock deformation and faulting are invariant with depth in drill hole USW G-1 and suggest that the stresses are limited by rock deformation in the present-day stress field. The ratio of shear to normal stress may be interpreted as a dimensionless coefficient of friction in a Mohr-Coulomb frictional faulting model. We explicitly avoid that association, however, to reach the more general conclusion that some failure mechanism is limiting the stresses observed on Yucca Mountain.

The ground water system at Yucca Mountain may be coupled to the tectonic stress field. In crystalline rocks, most of the permeability and connected porosity is contained in open fractures. When rocks in an extensional environment begin to fail, fractures open, the porosity and permeability increase, and the hydrologic system may be modified. A magnitude 5.6 earthquake occurred, however, at Little Skull Mountain, $23 \mathrm{~km}$ southeast of the potential repository, in June 1992. Temporary earthquake-induced fluctuations of water level were measured in instrumented boreholes. The maximum estimated short-term waterlevel fluctuation from the Little Skull Mountain earthquake was $40 \mathrm{~cm}$. 


\section{REFERENCES CITED}

Oliver, H.W., Hardin, E.L., and Nelson, P.H., eds., 1990, Status of data, major results, and plans for geophysical activities, Yucca Mountain Project: U.S. Department of Energy Report YMP 90-38, 236 p.

U.S. Department of Energy, 1988, Site characterization plan--Yucca Mountain site, Nevada Research and Development Area, Nevada: U.S. Department of Energy, DOE/RW-0199, Office of Civilian Radioactive Waste Management, Washington, D.C., 7 volumes. 


\title{
MAJOR RESULTS OF GEOPHYSICAL INVESTIGATIONS AT YUCCA MOUNTAIN AND VICINITY, SOUTHERN NEVADA
}

\section{CHAPTER 1: INTRODUCTION AND GEOLOGIC SETTING}

\author{
By H. W. Oliver and D.A. Ponce
}

\section{INTRODUCTION}

On December 17, 1987, Congress named Yucca Mountain in Nevada as the only site in the United States to be characterized for long-term underground storage of high-level nuclear waste. This decision preempted earlier plans for the evaluation of at least three western sites by the Department of Energy (Oliver, 1987; American Geophysical Union, 1987; Manastersky, 1988; U.S. Department of Energy, 1986, p. 1). The location of the Yucca Mountain site relative to major physiographic features is shown in fig. 1.1, and the site's relation to terrain and drainage in southern Nevada and southeastern California is shown in fig. 1.2. The Nevada Test Site and the Yucca Mountain site area located in the southwestern part of the Nevada Test Site are depicted in fig. 1.3. Other areas within the Nevada Test Site that have been considered for storage of radioactive waste are Syncline Ridge, Wahmonie and the Calico Hills. Nuclear tests were initially made in Frenchman Flat, followed by larger tests in Yucca Flat, Rainier Mesa, and Pahute Mesa. The potential storage area for radioactive waste is shown in comparison to the "Preliminary Boundary of the Accessible Environment" (fig. 1.4). This environmental, hydrologic and geologic study boundary extends 3 to $6 \mathrm{~km}$ outside the approximate potential repository boundary to the eastern edge of the site area. The Site Area itself is about $12 \mathrm{~km}$ wide by $20 \mathrm{~km}$ long and is an informal boundary marking the area of detailed study by participants in the characterization of the Yucca Mountain site.

This volume is intended as a companion, and successor, to preceding descriptions of selected past and planned geophysical investigations at Yucca Mountain embodied in two documents, the Site Characterization Plan for the Yucca Mountain site (U.S. Department of Energy, 1988), and the report referred to as the "Geophysical White Paper, Phase I," entitled Status of Data, Major Results, and Plans for Geophysical Activities, Yucca Mountain Project, produced in 1990 and authored by H.W. Oliver, E.L. Hardin, and P.H. Nelson (Oliver and others, 1990). The Site Characterization Plan necessarily contained uncertainty about applicability and anticipated accuracy of geophysical methods then untried in the Yucca Mountain volcano-tectonic setting. The initial White Paper (Phase I) provided an integrated summary of geophysical survey coverage, data quality, and applicability of results as a means to relate planned and completed activities. That report for the most part did not present data or interpretation, and therein is the important distinction of the current volume. This White Paper (Phase II) presents data, results, and interpretations developed from application of selected geophysical methods to the task of characterization of the Yucca Mountain site, largely through 1990. This volume joins the preceding two documents in an overall plan to provide a synthesis of geophysical investigations at Yucca Mountain. It should be carefully noted that constraints of scheduling, funding, and applicability or availability of method(s) resulted in variability of the time frame of separate 


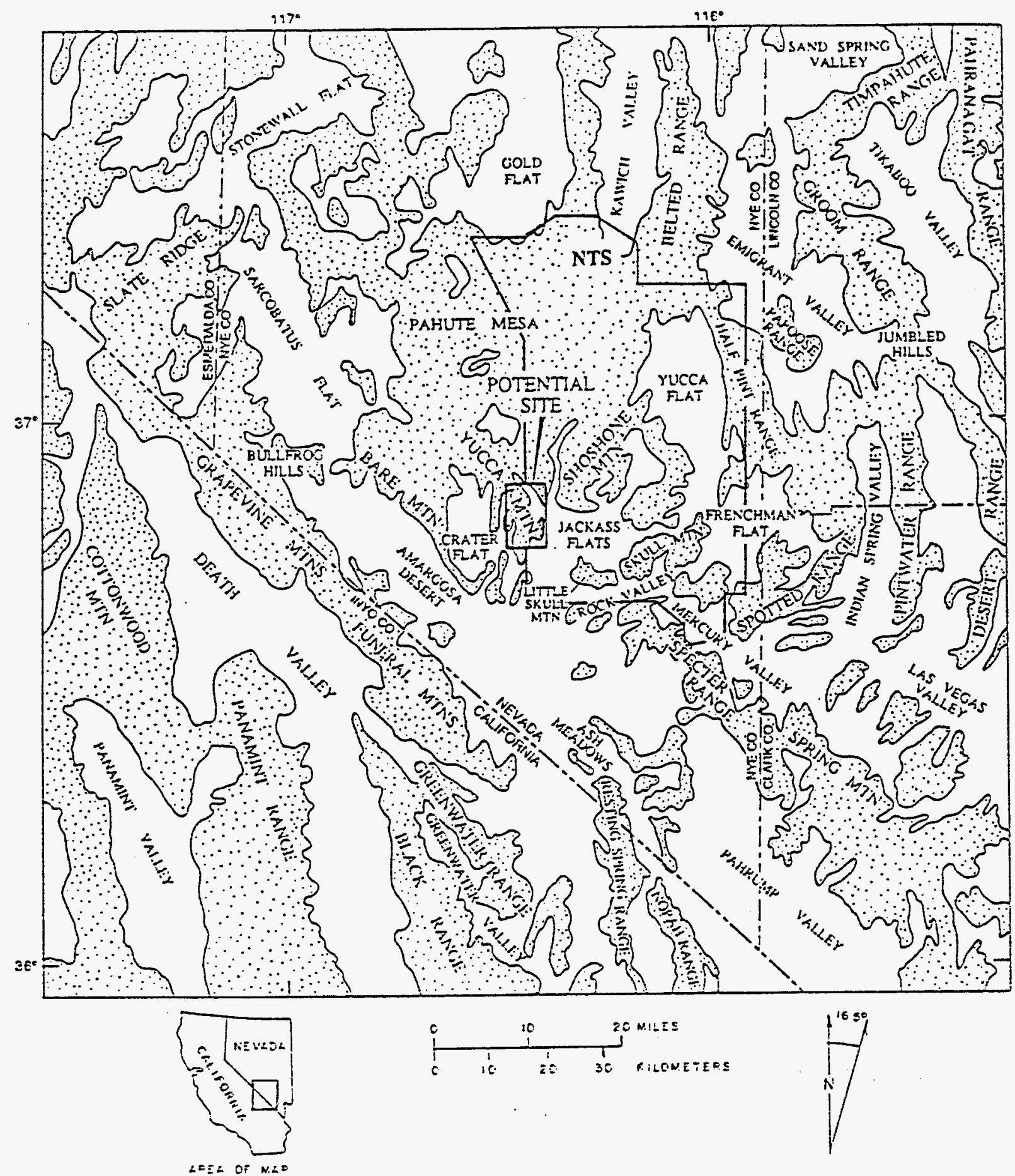

Figure 1.1 Location of Yucca Mountain site. Outline of the Nevada Test Site (NTS) is also shown. Elevated regions and major physiographic features are labeled. Modified from U.S. Geological Survey (1984, fig. 1). 

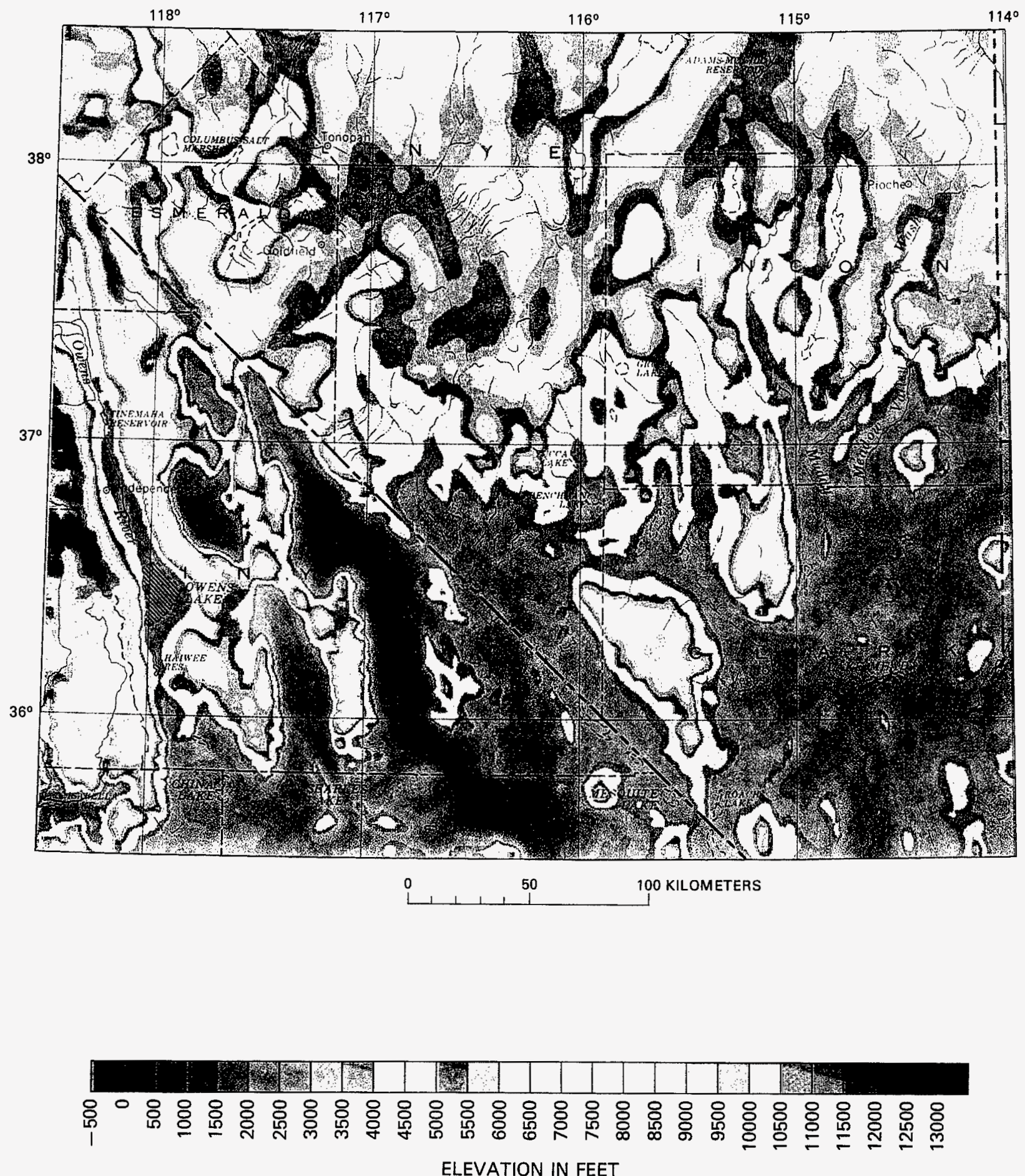

Figure 1.2. Terrain map of the southern Great Basin showing the potential site at Yucca Mountain. Modified from Hildenbrand and others (1988, fig. 2.5 ). 


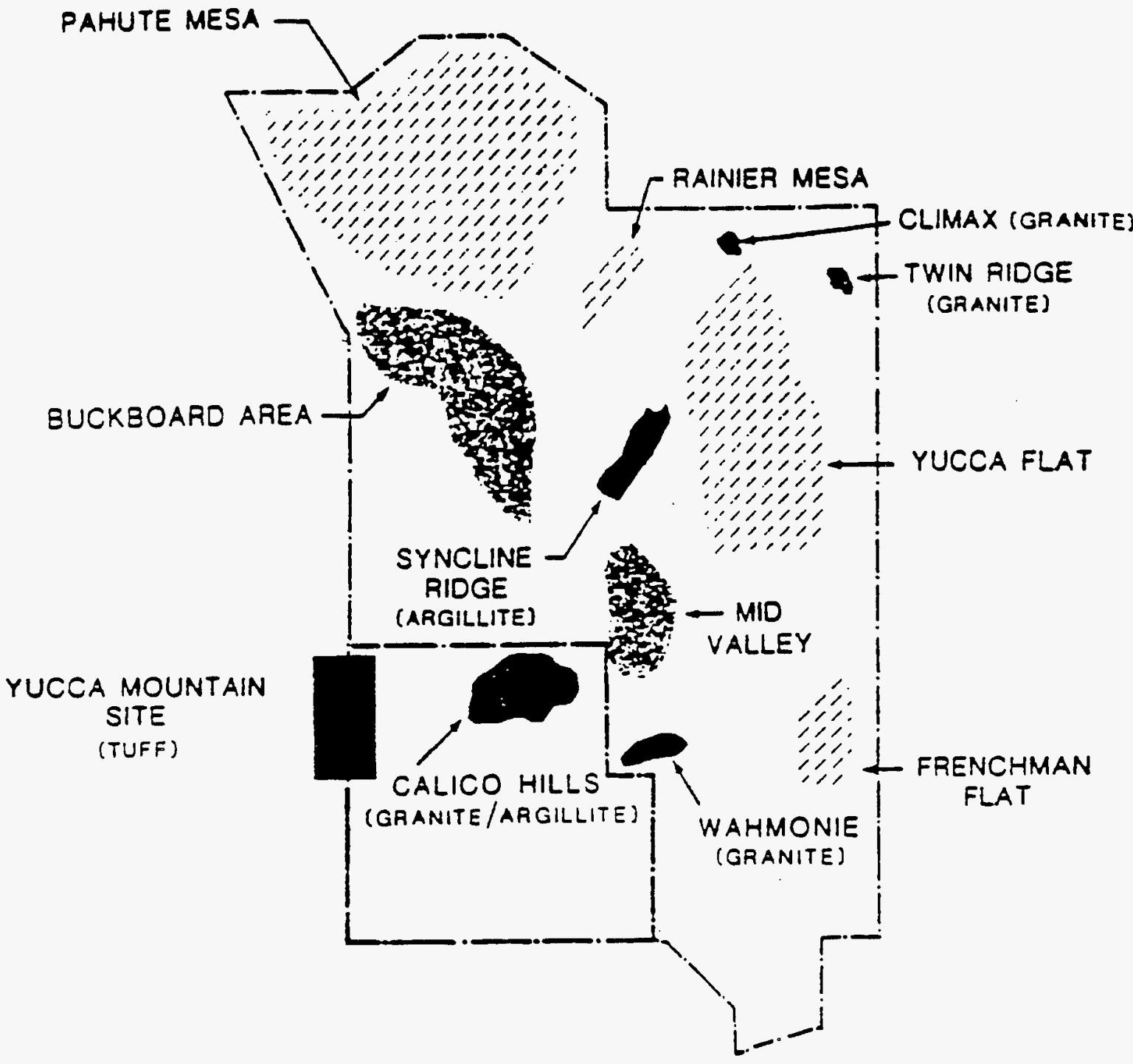

APPROXIMATE AREAS OF CURAENT OR

PAST WEAPONS TESTING

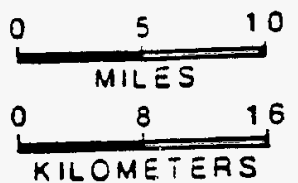

APPROXIMATE AREAS OF POTENTIAL WEAPONS TESTING

AREAS CONSIDERED AS POTENTIAL REPOSITORY SITES

Figure 1.3. Past, current, or potential future weapons-testing areas on the Nevada Test Site and areas initially considered for high-level nuclear waste storage. See fig. 1.1 for location of Nevada Test Site. Modified from U.S. Depurunent of Energy (1984, fig. 2-7). 


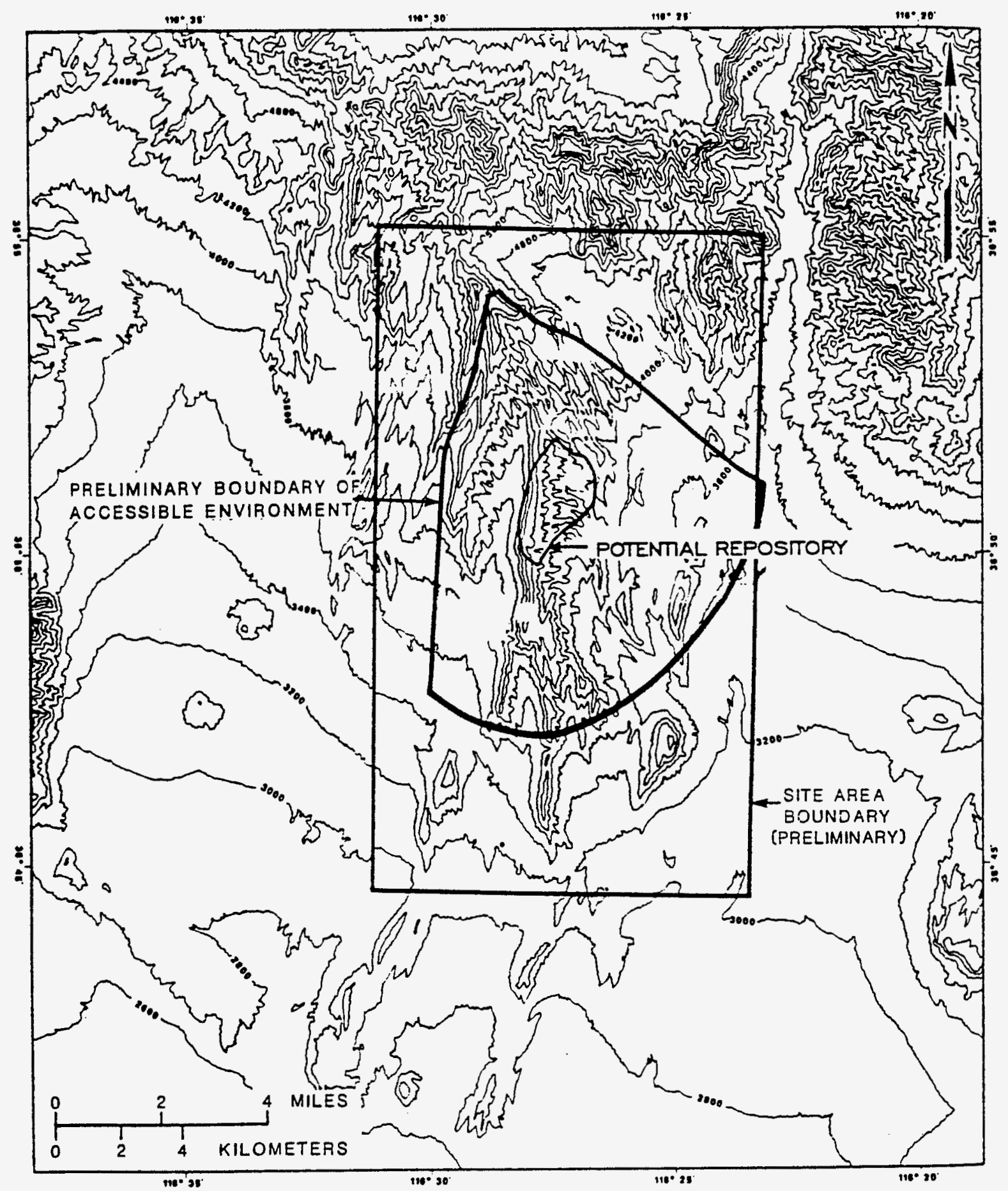

Figure 1.4. Locations of the potential repository and the preliminary boundary of accessible environment within the potential site area. Modified from U.S. Department of Energy (1988, fig. 8.3.1.4.-2). 
investigations, and separate chapters combined here were completed at various times over several years. Limited updates of data sets or interpretation are incorporated into some chapters, but an inconsistency of time frame is an unavoidable part of this document.

In considering Yucca Mountain and other locations as possible sites for storing high-level radioactive waste, the National Academy of Sciences (1978) and the Nuclear Regulatory Commission (1983) recommended study of a number of geologic topics, supported in part by geophysical investigations. These topics include (1) natural geologic and geochemical barriers to help contain possible contaminated ground water and isolate it from the biosphere, (2) future fluctuations in the water table that might flood an underground repository, (3) tectonic stability of the storage area, that is, likelihood that the area will be free from possible surface or underground rupture, (4) effects of shaking that might be caused by nearby earthquakes or other sudden releases of energy, and (5) possible volcanic eruptions that might redistribute stored radionuclides.

The area northeast of Yucca Mountain has been fairly well mapped geologically because of previous need to understand and contain transmission of energy from nuclear tests in Yucca Flat and on Pahute Mesa (fig. 1.3). A compilation of the regional geology is shown in figure 1.5. An introduction to the types of geologic problems of possible significance to waste isolation is appropriate here as a guide to the geophysical methods needed to assess subsurface geologic structures.

\section{REGIONAL GEOLOGIC PROBLEMS}

The regional geologic map (fig. 1.5) together with a regional Quaternary fault and seismicity map at the same scale (fig. 1.6) provide basic information on surface geology. A larger-scale geologic map of Yucca Mountain and vicinity is given in Chapter 2 (fig. 2.4) and indexed in figure 1.5. The regional geologic map (fig. 1.5) shows that Yucca Mountain is made up of Tertiary volcanic deposits which extend about $100 \mathrm{~km}$ to the north forming a plateau nearly $2 \mathrm{~km}$ above sea level (fig. 1.2). The $1000-\mathrm{km}^{2}$ area within which the potential site is located includes 32 Quaternary faults (fig. 1.6; Swadley and others, 1984). Pre-Cenozoic basement rocks crop out about $20 \mathrm{~km}$ west of Yucca Mountain at Bare Mountain, about $10 \mathrm{~km}$ northeast in the Calico Hills, and about $20 \mathrm{~km}$ southeast at Striped Hills (figs. 1.3 and 1.5).

The nature of the contact between Paleozoic and Cenozoic rocks beneath Yucca Mountain is an important factor in understanding the origin of Quaternary faults there and the associated seismic hazard. Two possibilities are that these faults could either merge with a low-angle fault at this contact, or they could cut the contact and continue to depth as planar faults. In the Calico Hills, however, the Paleozoic/Tertiary contact is marked locally by an erosional contact, with paleotopography on the Paleozoic rocks overlain by Tertiary sedimentary and volcanic depositional facies (Simonds, 1995). This depositional contact is best exposed along the southern margin of the Calico Hills, and juxtaposition of Paleozoic and Tertiary sequences by normal faulting elsewhere in the Calico Hills appears to have occurred later than the depositional contact. The Paleozoic/Tertiary contact is a hydrologic barrier; the ground water in the pre-Cenozoic rocks below the contact has a head $20 \mathrm{~m}$ higher than in Cenozoic rocks above the contact (Craig and 

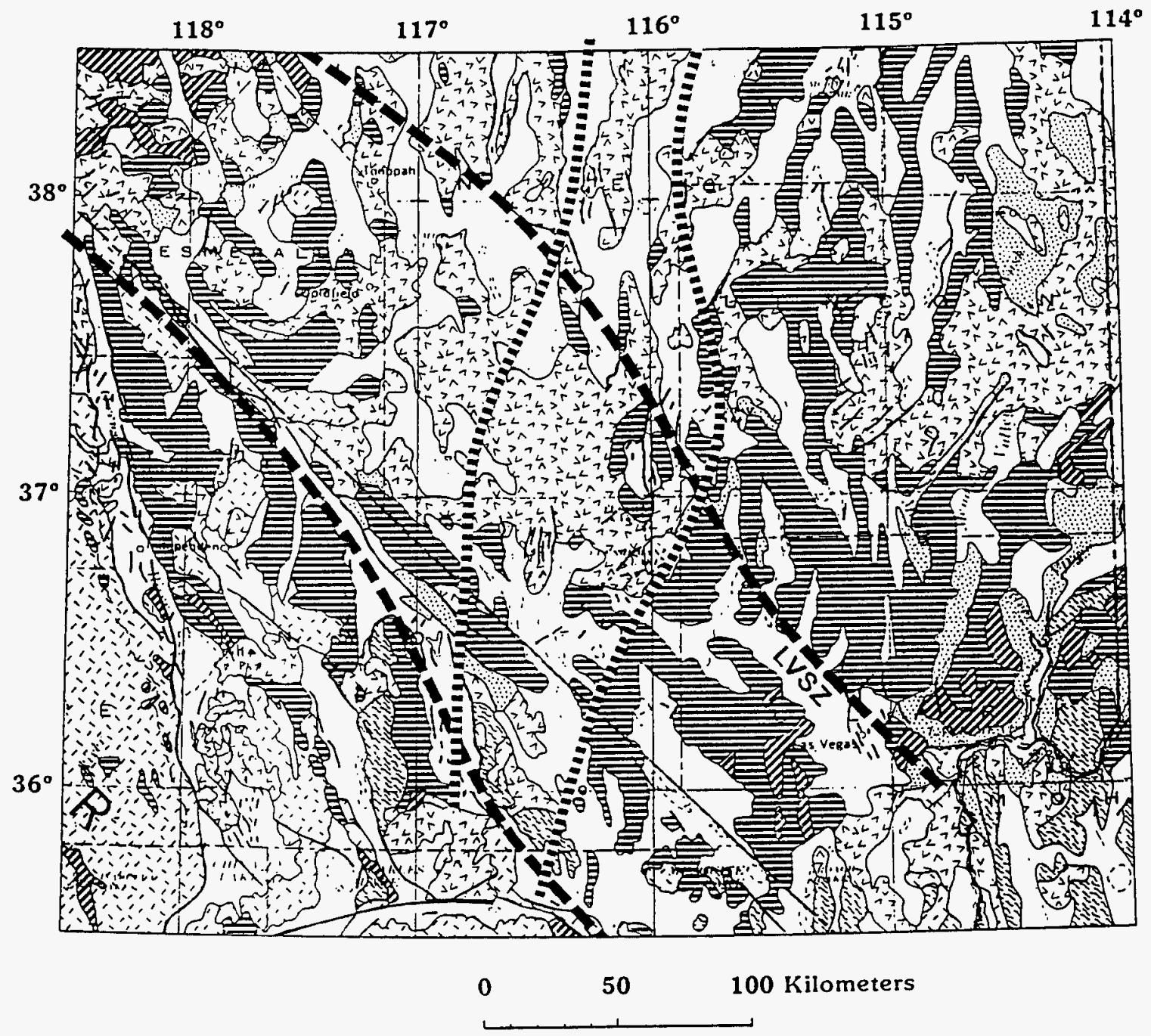

\section{EXPLANATION}

Sedimentary and volcanic deposits (Quaternary)
Solcanic deposits (Tertiary)
Intrusive rocks (Cenozonic and Mesozo ic)
Sedimentary and volcanic rocks (Mesozo ic)
Sedimentary and metasedimentary rocks (Paleozoic and Late Proterozoic)
LSZ - Las Vegas Shear Zone

Figure 1.5. Generalized geologic map of the southem Great Basin. Long dashed lines are approximate boundaries of the Walker Lane structural belt; short dashed lines are boundaries of the Death Valley-Pancake Range volcanic zone. The Las Vegas shear zone (LVSZ) is shown within the Walker Lane. The rectangular area delineates a map area also shown in fig. 2.4. Modified from King and Beikman (1974). 


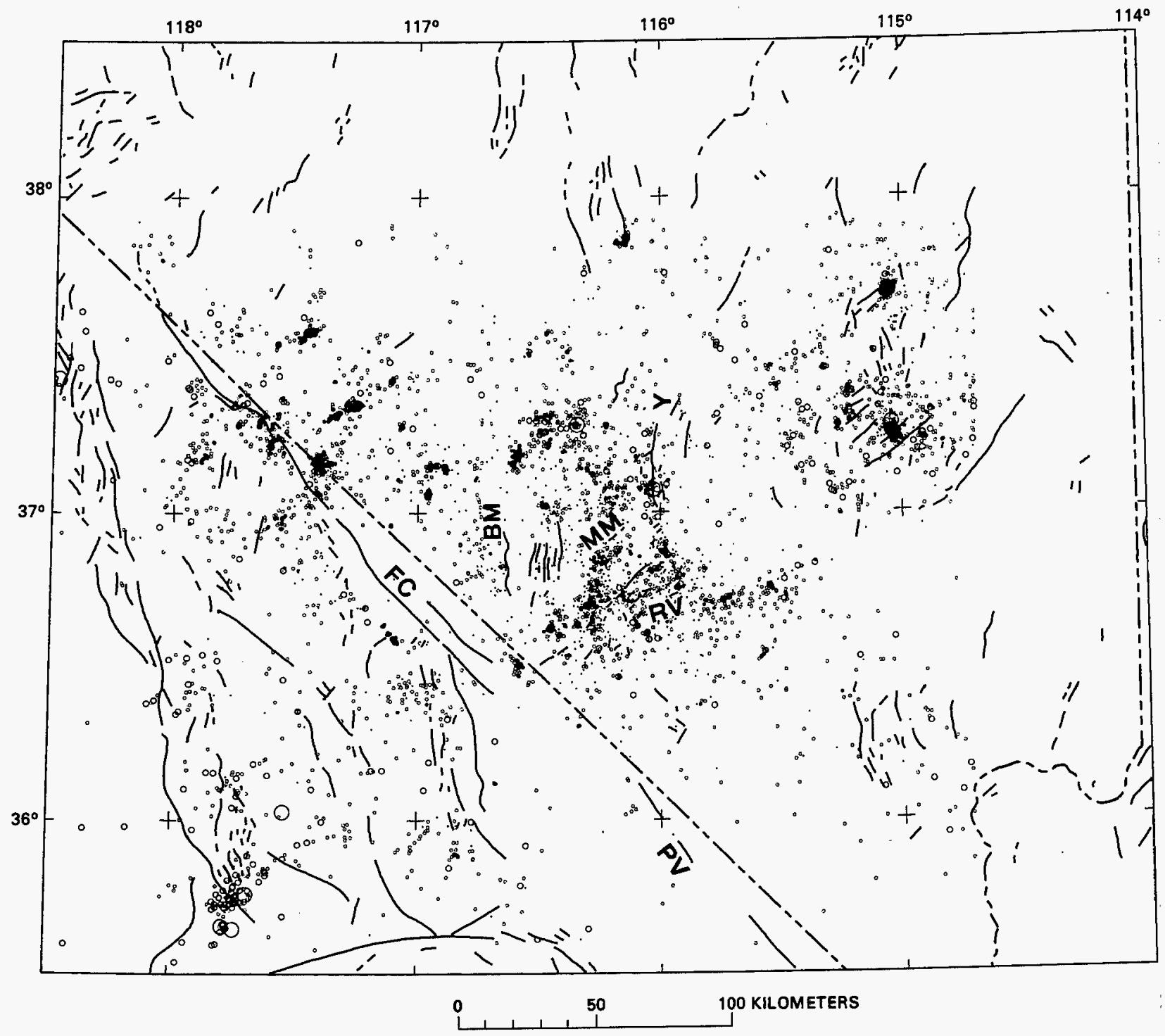

\section{EXPLANATION}

\section{Earthquake epicenters}

Magnitude

○ $\quad M>3$

- $2<M \leq 3$

$1<M \leq 2$

$M \leq 1$

\section{Quaternary fault}

Figure 1.6. Location of potential site relative to Quaternary faults and earthquake epicenters which occurred from August 1978 through December 1986. Faults discussed in text are labeled as follows: BM, Bare Mountain fault; FC, Furnace Creek fault; MM, Mine Mountain fault zone; PV, Pahrump Valley fault; RV, Rock Valley fault zone; Y, Yucca fault. FC is right-lateral; RV and MM are left-lateral. BM is a normal fault, down to the east. Modified from Hildenbrand and others (1988). 
Johnson, 1984). Regional geophysical studies indicate that this contact slopes west about $15^{\circ}$ from a depth of $1.1 \mathrm{~km}$ below eastern Yucca Mountain to a depth of more than $3 \mathrm{~km}$ in Crater Flat (Oliver and Fox, 1993). Regional ground-water movement is controlled by aquatards, aquifers, and structural features within the pre-Cenozoic basement rocks (Winograd and Thordarson, 1975). Determination of the approximate areal and vertical distribution of these features through geophysical mapping is needed to help establish the ground water travel paths and travel times.

Evaluation of subsurface structures associated with the Walker Lane belt (fig. 1.5) and potential active faulting is also needed. The Walker Lane belt, which includes the Yucca Mountain area, has been interpreted as a diffuse intracontinental boundary zone along which right-lateral wrench faulting such as that along the Las Vegas Shear Zone predominates (Stewart, 1988). The Death Valley extensional area, about $20 \mathrm{~km}$ west of Yucca Mountain, is generally recognized as an area of active contemporary tectonism (Burchfiel and others, 1987). Geophysical studies may help determine the extent to which Yucca Mountain is linked to or decoupled from this region of active faulting.

The Walker Lane belt (fig. 1.5) has been seismically active recently, particularly between $36^{\circ}$ $30^{\prime} \mathrm{N}$ and $37^{\circ} 30^{\prime} \mathrm{N}$. Within this broad zone, several local zones of diffuse seismicity are associated with known Quaternary faults such as the northeast-striking Rock Valley fault zone and the northstriking zones associated with the Yucca fault (fig.1.6). A second north-striking zone intersects the western parts of the Rock Valley and Mine Mountain faults obliquely. At about $37^{\circ} \mathrm{N}$, the zone of seismicity expands both to the east and to the west forming an east-west trend across the Walker Lane belt from $115^{\circ} \mathrm{W}$ into California at $118^{\circ} \mathrm{W}$. This trend is not continuous but consists of three concentrations of seismicity centered around $115^{\circ}, 116^{\circ} 30^{\prime}$, and $117^{\circ} 45^{\prime}$ west longitude. No through-going east-west Quaternary faults break the surface within this seismic zone.

Basaltic lava, scoria, and ash erupted from vents west of Yucca Mountain at $3.7 \mathrm{Ma}$ (intersected in drill hole USW VH-1; Carr, 1982), in central Crater Flat at 1.2 Ma (Crowe and others, 1983), an age modified to 1.0 to $1.1 \mathrm{Ma}$ in later studies (Crowe and others, 1995), and at southern Yucca Mountain (southeastern Crater Flat) 10,000 to 150,000 years ago (Crowe and others, 1992; Crowe and others, 1995). These occurrences are part of the Death Valley-Pancake Range volcanic zone (Carr, 1984, 1990), a diffuse region of late Pliocene and Quaternary basaltic eruptive rocks (fig. 1.5) The distribution of late Pliocene and Quaternary basaltic cones within $10 \mathrm{~km}$ of the Potential Site is shown on the detailed geologic map (fig. 1.7). Estimation of the probability that magma might invade the repository site sometime over the next 10,000 years requires information on the distribution, volume, and ages of buried basalts (Crowe and others, 1983; Crowe and others, 1995). Several aeromagnetic anomalies found in Crater Flat and the northern Amargosa Desert could be caused by buried basalt cones (see chap. 3 ). 


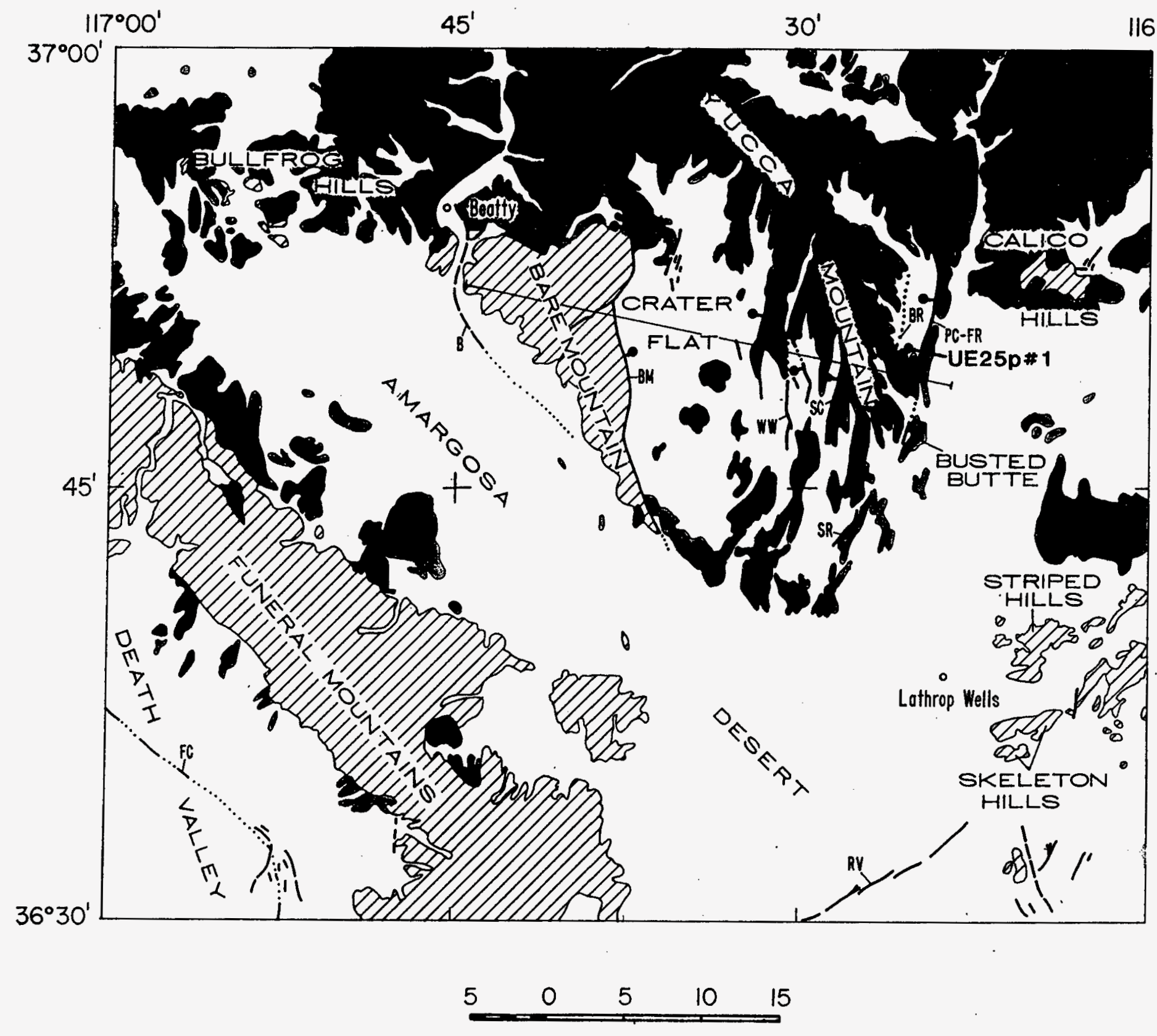

Figure 1.7. Generalized geologic map of the Crater Flat-Yucca Mountain area, emphasizing faults with known or suspected Quaternary displacement and Pliocene and Quatemary basaltic volcanoes. Explanation of patterns: diagonal lines, Precambrian and Paleozoic rocks; shaded, Tertiary volcanic and sedimentary rocks; black, late Pliocene and Quaternary basalt; unpatterned, Quatemary surficial deposits. Explanation of symbols: B, Beatty scarp (faulting suspect); BM, eastern range-front fault of Bare Mountain; BR, Bow Ridge fault; FC, Furnace Creek fault; PC-FR, Paintbrush Canyon-Fran Ridge fault zone; RV, Rock Valley fault; SC, Solitario Canyon fault; SR, Stage Coach Road fault; WW, Windy Wash fault; UE25 p 1, location of drill hole to pre-Cenozoic "basement" rocks. Generalized from Comwall (1972) and Streitz and Stinson (1974). Modified from M.D. Carr (written commun., 1988). 


\section{GEOPHYSICAL METHODS}

The gravity method, combined with limited seismic refraction and drilling methods, has been the most economically successful technique for determining the configuration of the pre-Cenozoic basement in southern Nevada (Healey, 1968; Snyder and Carr, 1984; chaps. 2 and 5, this volume) Lithologic, density, and sonic logs combined with surface measurements of gravity are essential to control two- and three-dimensional computer models of the upper crust (for example, Muller and Kibler, 1984, pl. 1). Electrical methods, particularly magnetotelluric methods, are also helpful in characterization of the upper and middle crust, and preliminary results (chap. 5, this report) indicate the desirability of more of this work.

Late Proterozoic and Paleozoic rocks composing the basement underlying the Cenozoic volcanic and surficial deposits at and near Yucca Mountain include (from oldest to youngest) 2 to $7 \mathrm{~km}$ of siliceous clastic rocks (quartzite, siltite), $4.5 \mathrm{~km}$ of carbonate rocks (limestone, dolomite), and 2 to $3 \mathrm{~km}$ of interlayered argillite, quartzite, and limestone (U.S. Geological Survey, 1984). These rocks have been invaded by granite at several localities. Basement rocks whose geophysical signature is sought thus include five rock types: (1) siliceous clastic rocks, (2) limestone, (3) dolomite, (4) argillite, and (5) granitic rocks. Stratified rocks were thrusted and folded in Mesozoic time and then partially dismembered by low-angle extensional faulting in late Cenozoic time. Thus, neither their vertical arrangement nor their lateral distribution can be predicted from surface mapping (K.F. Fox, written commun., 1988). Geophysical methods must be used instead. General physical properties of these chief rock types are summarized in table 1.

Densities range from about 2.5 to $2.85 \mathrm{~g} / \mathrm{cm}^{3}$ for the basement rocks, but densities of the chief lithologic types overlap significantly. The density contrast between basement rocks and Cenozoic cover ranges from 0.25 to $1.25 \mathrm{~g} / \mathrm{cm}^{3}$. This large contrast causes the gravity field to be very sensitive to the configuration of the basement surface and the distribution of Cenozoic rocks but at the same time masks the much smaller contrasts between basement rock types. Because the dolomites are the most dense, however, gravity highs generally occur over them within areas of exposed basement rocks. Seismic velocities are similar to densities in that there is considerable overlap in values from different rock types. Significant fracturing of these basement rocks, however, may be detected by reduced velocities (Ackermann and others, 1988).

Magnetic susceptibility of the basement rocks ranges over several orders of magnitude, from $10^{-}$ 6 to $10^{-2} \mathrm{emu} / \mathrm{cm}^{3}$. Using magnetic susceptibility to distinguish basement rock types is complicated, however, because there are both nonmagnetic and magnetic argillic rocks in the southwestern part of the Nevada Test Site. Nonmagnetic argillite, such as that at Syncline Ridge (fig. 1.3; Ponce and Hanna, 1982), has a susceptibility of about $10^{-6} \mathrm{emu} / \mathrm{cm}^{3}$, and magnetic argillite that has been altered, such as at Calico Hills (fig. 1.3; Snyder and Oliver, 1981), has a susceptibility of about $10^{-3}$ to $10^{-2} \mathrm{emu} / \mathrm{cm}^{3}$. Where close to the surface, the magnetic argillite produces sharp magnetic highs, but where deeply buried, its magnetic signature cannot be distinguished from that of magnetic granitic rocks.

The resistivity of all three basement rock types is generally quite high (>100 ohm-m) Where the dolomites are fractured and carry even a few percent water, however, the resistivity may be 
Table 1.1.-Physical properties of rocks based on several hundred sample measurements and several bore-hole logs (Snyder and Oliver, 1981; Ponce and Hanna, 1982; Healey and others, 1984; Muller and Healey, 1986; Hoover and others, 1982; Frischknecht and Raab, 1984; Snyder and Carr, 1984).

\begin{tabular}{|c|c|c|c|c|}
\hline Rock Type & $\begin{array}{l}\text { Density } \\
\left(\mathrm{gm}^{2} \mathrm{~cm}^{3}\right)\end{array}$ & $\begin{array}{l}\text { Velocity } \\
(\mathrm{km} / \mathrm{s})\end{array}$ & $\begin{array}{l}\text { Magnetic } \\
\text { susceptibility } \\
\text { (emu/ } \mathrm{cm}^{3} \text { ) }\end{array}$ & $\begin{array}{l}\text { Resistivity } \\
\text { (ohm-m) }\end{array}$ \\
\hline \multicolumn{5}{|c|}{ Pre-Cenozoic basement rocks } \\
\hline Argillite & $2.6-2.7$ & $5.4-5.8$ & $10^{-6}-10^{-2}$ & $>100$ \\
\hline Granite & $2.62-2.75$ & $5.6-6.1$ & $10^{-4}-10^{-3}$ & $>100$ \\
\hline Dolomite & $2.7-2.85$ & $5.8-6.5$ & $10^{-6}$ & $20-200$ \\
\hline Limestone & $2.6-2.7$ & $5.3-5.8$ & $10^{-6}$ & $20-200$ \\
\hline $\begin{array}{l}\text { Siliceous } \\
\text { clastic rocks }\end{array}$ & $2.50-2.65$ & $5.0-5.6$ & $10^{-6}$ & $>100$ \\
\hline \multicolumn{5}{|c|}{ Cenozoic deposits } \\
\hline $\begin{array}{l}\text { Miocene volcan } \\
\text { rocks }\end{array}$ & $1.8-2.5$ & $3-5$ & $0-10^{-2}$ & $10-1000$ \\
\hline $\begin{array}{l}\text { Quaternary } \\
\text { surficial } \\
\text { deposits }\end{array}$ & $1.4-2.3$ & $2-4$ & $0-10^{-4}$ & $5-1000$ \\
\hline
\end{tabular}

significantly reduced $(<50 \mathrm{ohm}-\mathrm{m})$ with the contrast detectable by electrical surveys (Hoover and others, 1982).

Seismic reflection methods have been used sparingly at Yucca Mountain because of their considerable expense and problems of high absorptivity of elastic wave energy by the highly porous volcanic rocks at Yucca Mountain (H.D. Ackermann, written commun., 1984). Recent tests made in the Amargosa Valley to the southwest (fig. 1.1) are encouraging (chap. 6, this report), however, and indicate that the Las Vegas shear zone, the Walker Lane belt, and other regional tectonic features could be imaged using this method.

The teleseismic method (chap. 7, this report) uses travel-time data recorded on a 53-station seismic network established primarily to determine contemporary local seismicity (fig. 1.6; see Hildenbrand and others, 1988 , p. $4-5$ for specifications of the network). The seismic network also 
records distant earthquakes $(>1,000 \mathrm{~km}$ distant $)$, and relative arrival times can be converted to a three-dimensional velocity image of southern Nevada to a depth of about $300 \mathrm{~km}$. This inexpensive method, combined with seismic refraction data to strip off near-surface seismic anomalies, is capable of defining the depth, extent, and overall nature of the Walker Lane structural belt, the Death Valley-Pancake Range volcanic belt, and the Timber Mountain caldera complex.

Regional heat flow studies (chap. 8, this volume) are essential to an understanding of the regional ground-water and isothermal flow paths and possible radionuclide pathways to the biosphere. For a review of selected geophysical methods, procedures, and measurements at Yucca Mountain and vicinity, see Oliver and others (1990), Oliver and others (1982), and Oliver (1984). For a more general discussion of the role of geophysics for characterizing high-level radioactive waste repositories, see Wynn and Roseboom (1987).

Stress measurements at Yucca Mountain (chap. 9, this report) indicate that rocks at Yucca Mountain are close to their limiting strength. The state of stress by itself, however, does not pose a threat to a potential repository. Stress measurements are important because they relate to other mechanisms that may threaten a potential repository, including earthquakes, volcanism, and faulting. A concern associated with the state of stress is the possibility of some interaction between the stress field and the hydrologic regime that might result in change of the level of the water table.

\section{GEOLOGIC SETTING}

Yucca Mountain comprises a series of north-striking, eastward-tilted structural blocks bounded by steeply westward-dipping Cenozoic faults (figs. 1.7 and 1.8; Christiansen and Lipman, 1965; Lipman and McKay, 1965; Scott and Bonk, 1984). These blocks consist of terrigenous volcanic and sedimentary rocks, mostly of Miocene age. The Tertiary rocks rest on a pre-Cenozoic basement consisting, at least in part, of Paleozoic marine sedimentary strata. A summary of the geology of Yucca Mountain has been published by the U.S. Geological Survey (1984). The present discussion summarizes some of the geologic problems yet to be resolved in evaluating Yucca Mountain as a potential disposal site for high-level nuclear waste, concentrating on those problems to be addressed substantially on the basis of geophysical techniques. The reader should note the position of this report, as mentioned above, in a sequence of efforts describing geophysical investigations at Yucca Mountain. The Site Characterization Plan (U.S. Department of Energy, 1988) and the Geophysical White Paper, Phase I (Oliver and others, 1990), are important precursors to the present volume.

Depths to the base of the Tertiary section in the vicinity of Yucca Mountain (fig. 1.7) were estimated by Snyder and Carr (1984) on the basis of gravity data to range from about $1 \mathrm{~km}$ near Busted Butte to more than $4 \mathrm{~km}$ in Crater Flat. Uncertainty in the density contrasts used for gravity modeling made these estimates reliable only to within about \pm 30 percent of the estimated depth. Seismic-refraction profiles suggest that the base of the Tertiary section is approximately 3.2 $\mathrm{km}$ below the surface of Crater Flat (Ackermann and others, 1988). These depth estimates were, in part, confirmed by a drill hole [UE-25 $\mathrm{p \# 1]}$ that intersected pre-Tertiary rocks about $1.25 \mathrm{~km}$ 

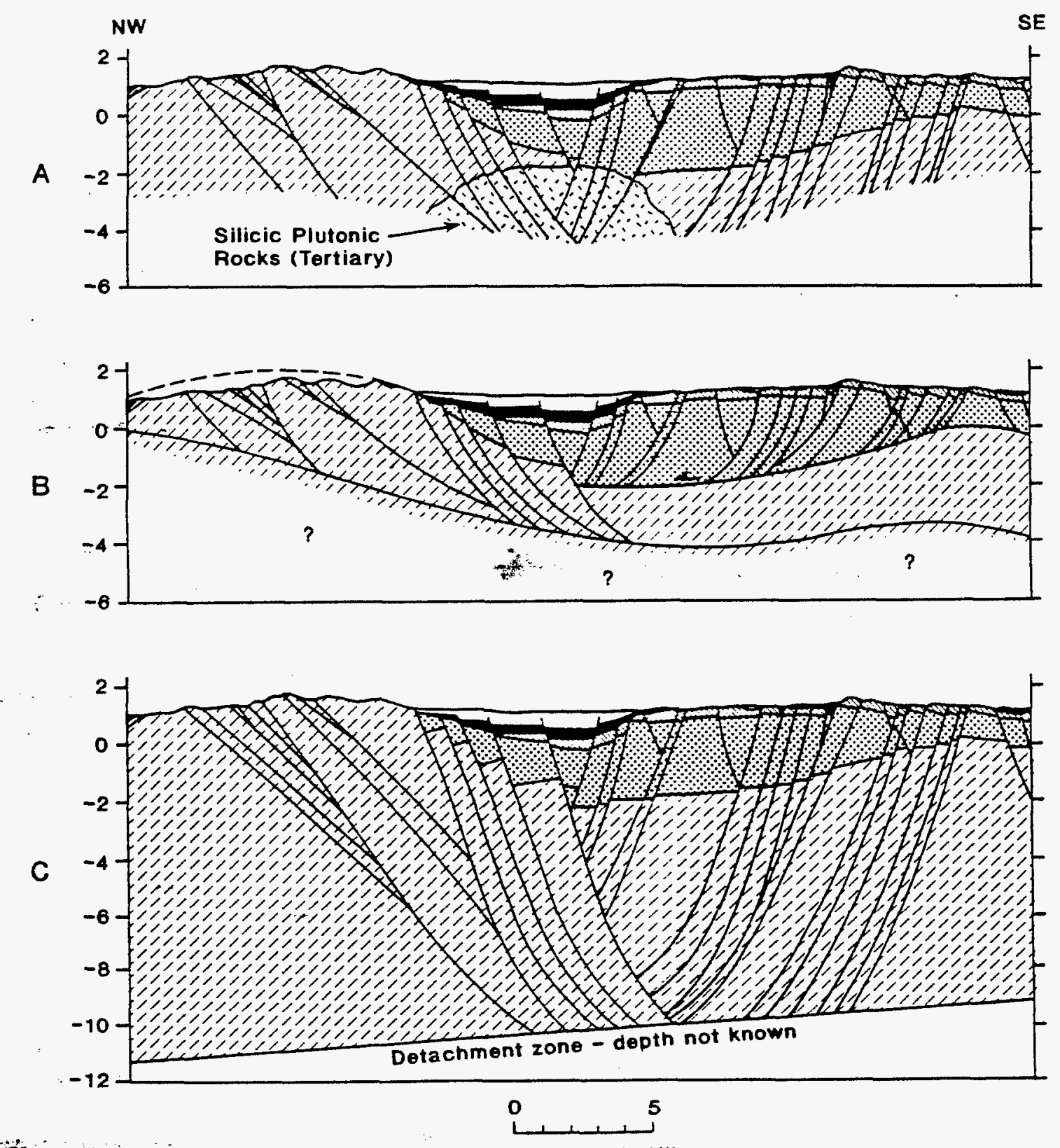

Approximate Scale in Kilometers

Surticial deposits (Quaternary)

Timber Mountain Group (Miocence)

Paintbrush Group (Miocene)

Volcanic and sedimentary deposits (Pre-Paintbrush Group.. Miocene and Oligocene?)

Pre-Cenozoic basement rocks (mostly upper Proterozoic and Paleozoic miogeosynclinal sedimentary or metasedimentary rocks)

Figure 1.8. Schematic cast-west geologic cross sections across central Crater Flat showing some altemative interpretations of the subsurface structural geometry. Symbols: A, Crater Flat interpreted as a middle Miocene caldera (modified from Snyder and Car, 1984); B, listric fault model accommodated by a detachment fault at the base of the Tertiary section (modified from Scott, 1990); C. planar near-surface faulting model accommodated by ductile fattening and (or) low-angle normal faulting in middle cnust. The approximate line of this section shown in figure 1.7. Modified after U.S. Geological Survey (1984, fig. 4, west half of section A-A'). After M.D. Carr, written commun., 1988). 
below eastern Yucca Mountain, $5 \mathrm{~km}$ north of Busted Butte (fig. 1.7; Carr, Waddell, and others, 1986). Paleozoic marine carbonate rocks, part of a regional aquifer in the deep ground-water flow system of the southern Great Basin, represent the pre-Cenozoic basement in the drill hole. The composition of the pre-Cenozoic basement under the northern part of Yucca Mountain remains unknown. Interpretations based on gravity and magnetic data predict either intrusive rocks (Snyder and Carr, 1984) or Mississippian clastic rocks (Bath and Jahren, 1984) beneath northern Yucca Mountain.

The westward-dipping faults that cut Yucca Mountain are part of a system of normal and (or) oblique-slip faults in the eastern wall of a westward-deepening asymmetric graben that extends in east-west profile from Bare Mountain at least as far east as eastern Yucca Mountain (fig. 1.8). The subsurface geometry, kinematics, and mechanics of this fault system, as well as the extent, origin, and history of the Crater Flat-Yucca Mountain graben remain unresolved. A persisting question concerns whether the faults at Yucca Mountain are predominantly listric, flattening to a detachment surface at the base of the Tertiary strata (fig. 1.8B), or whether they are mostly planar-rotational faults that penetrate deeper into the crust before they are accommodated by some sort of low-angle extensional surface, possibly a low-angle normal fault within pre-Cenozoic strata or in the ductilebrittle transition zone (fig. 1.8C). Available geophysical data are insufficient to determine the fault geometry, which is important in assessing the seismic source and displacement potential of the faults, as well as their possible influence on hydrology. There is no doubt that, as a whole, the fault system at Yucca Mountain remains active, but the rate of contemporary tectonic activity for the system and for individual faults remains a subject of intensive investigations being conducted as part of the Site Characterization program. The state of stress within Yucca Mountain is consistent with active normal faulting in the principal system of westward-dipping faults (Stock and Healey, 1988). A critical element in the prediction of future activity on this fault system is a more concrete understanding of the interactive role of the Yucca Mountain fault system within the tectonic framework of the southern Great Basin.

The Crater Flat-Yucca Mountain graben was interpreted as a Miocene caldera (fig. 1.8A) by Snyder and Carr (1984) and Carr (1988). The gravity low that coincides with the graben continues south of Crater Flat into the Amargosa Desert (Healey and Miller, 1972; Snyder and Carr, 1984), however, and an east-west seismic-refraction profile crossing the Amargosa Desert about $10 \mathrm{~km}$ south of Lathrop Wells (Mooney and Schapper, chap. 5, this volume) shows a structural depression in the inferred surface of pre-Cenozoic basement rocks that has dimensions similar to and generally on trend with the Crater Flat-Yucca Mountain graben.

The set of east-dipping faults that control the western wall of the Crater Flat-Yucca Mountain graben at Bare Mountain formed before intrusion of 13.9-Ma quartz latite dikes, which cut some of these faults (Carr and Monsen, 1988). Therefore, the inception of faulting along the western wall of the graben system predated the inferred caldera in Crater Flat, which was postulated as the source of the 13.4- to 13.6-Ma Crater Flat Group (Carr, Byers, and Orkild, 1986; Sawyer and others, 1994). Faults in both walls of the Crater Flat-Yucca Mountain graben exhibit evidence for episodes of movement younger than $13.9 \mathrm{Ma}$, and some of these faults, including the Bare Mountain range front, and the Windy Wash, Solitario Canyon, and Paintbrush Canyon-Fran Ridge faults, remain active. Thus, the faults at Yucca Mountain appear to be part of a long-lived system 
of faulting in the Crater Flat-Yucca Mountain graben, which appears to extend southward and may also extend northward of its area of active surface rupture in Crater Flat and at Yucca Mountain. If a Miocene caldera existed in the Crater Flat area, then volcanism probably was localized by faulting within an areally more extensive and longer-lived structure, rather than volcanism and caldera formation being the cause of the faulting. The waning of silicic volcanism in the late Miocene does not necessarily imply a concomitant cessation of significant tectonic activity as suggested by Carr (1984), but rather, it may signal fundamental changes in the tectonic framework and different rates of continuing tectonic activity. The long and episodic history of tectonic and volcanic activity in the Crater Flat-Yucca Mountain graben makes it especially important to distinguish those structural and volcanic features that remain active and to evaluate independently the causes and consequences of the contemporary tectonic regime.

The coincidence of a Quaternary basalt field with the Crater Flat-Yucca Mountain graben (fig. 1.7) suggests that the graben is a deep-seated structure and that a genetic relationship exists between patterns of faulting and the site of volcanism. Seismic-reflection data from nearby Death Valley were interpreted as indicating that a moderately steep fault serves as a magma conduit between a Quaternary cinder cone and a zone of high-amplitude, relatively broad-bank reflections at $6 \mathrm{~s}(15 \mathrm{~km}$ ), interpreted as a partially molten intrusion (deVoogd and others, 1986). A similar relationship between faulting and volcanism might be hypothesized for the Crater Flat basalt field, but geophysical data are as yet insufficient to evaluate this hypothesis. Neither are there sufficient data pertinent to crustal structure to suggest why Quaternary volcanism in the Great Basin (other than that coincident with the margins of the province) is confined to a 50 - to $100-\mathrm{km}$-wide zone roughly medial to the southern Great Basin between Death Valley and the Pancake Range (fig. 1.5; Crowe and others, 1986). Identifying the source of the basaltic magmas and structural controls on the locations of eruptive centers within the Death Valley-Pancake Range volcanic zone is certainly germane to the estimation of future volcanic activity in the vicinity of Yucca Mountain.

The Crater Flat-Yucca Mountain graben lies within a region typified by a complex interplay of extensional and wrench-fault tectonics. Analyses of focal-mechanism data provide an impression that strike-slip faulting is the predominant generator of contemporary seismicity in the southern Great Basin (Rogers and others, 1983). The coincidence of recent seismic activity and (or) Quaternary surface rupture with important northeast- and northwest-striking zones of wrench faulting, such as the Rock Valley and Mine Mountain faults, the Pahranagat shear zone, and the Death Valley-Furnace Creek fault zone, emphasizes the continued importance of such fault systems as potential seismic sources within the regional setting. Yucca Mountain lies within the Walker Lane, a poorly understood belt of dextral oroclinal bending that generally parallels the NevadaCalifornia border. The Walker Lane seems to have served as an important, albeit diffuse, intraplate boundary between tectonic subprovinces of the Great Basin during the Cenozoic, and wrench faulting apparently continues to play an important role in the evolution of this belt.

In contrast, areally extensive low-angle normal faults (detachment faults), such a those exposed in the northwestern Spring Mountains (Burchfiel, 1965), the Bullfrog Hills-Bare Mountain area (Ransome and others, 1910), and the mountain ranges around Death Valley (Noble, 1941; Hunt and Mabey, 1966) also have been integral in the tectonic development of the southern Great Basin. While some of these low-angle faults appear at the surface to be inactive remnants of major middle- 
and late-Miocene structures, others (especially those west of the Death Valley-Furnace Creek fault zone) show evidence for activity and in some cases initiation during Pliocene and Quaternary time (Burchfiel and others, 1987). Many current models of crustal extension (for example, Hamilton, 1987) predict that even the steepest range-front faults in the Great Basin must be accommodated at some depth along gently dipping zones of detachment, whether they be the base of the crust, the ductile-brittle transition zone, or some brittle low-angle normal fault within the upper crust. The depth at which steep faults are accommodated and the location within the crust of low-angle faults, which could themselves be seismic sources or could obscure other deeper seismic sources, seem fundamental parameters for evaluating the size and location of potential seismic sources in the southem Great Basin.

A complex interplay between detachment surfaces, low- and high-angle normal faults, and wrench faults exists in the southern Great Basin. The predominance of one structural style over another varies with location, scale, and time. The kinematic behavior of individual structures may vary as the mechanical framework varies with time. Adequate characterization, or even identification, of tectonic features that could affect future faulting, surface rupture, ground motion, volcanism, and (or) the hydrology at Yucca Mountain requires a better understanding of how the structural features in the vicinity of Yucca Mountain fit into the evolving regional geologic system. The geologic setting of Yucca Mountain cannot be understood out of regional context, nor can the future performance of an arbitrarily restricted part of the geologic system be meaningfully assessed out of context. 


\section{REFERENCES CITED}

Ackermann, H.D., Mooney, W.D., Snyder, D.B., and Sutton, V.D., 1988, Preliminary interpretation of seismic-refraction and gravity studies west of Yucca Mountain, Nevada and California, in Carr, M.D., and Yount, J.C., eds., Investigations of the geological and geophysical characterization of a potential nuclear waste disposal site at Yucca Mountain, southern Nevada: U.S. Geological Survey Bulletin 1790, p. 23-34.

American Geophysical Union, 1987, News: EOS (Transactions), American Geophysical Union, v. 68 , no. 52, p. 1810.

Bath, G.D., and Jahren, C.E., 1984, Interpretations of magnetic anomalies at a potential repository site located in the Yucca Mountain area, Nevada Test Site: U.S. Geological Survey Open-File Report, 84-120, $40 \mathrm{p}$.

Burchfiel, B.C., 1965, Structural geology of the Specter Range quadrangle, Nevada, and its regional significance: Geological Society of America Bulletin, v. 48, p. 40-56.

Burchfiel, B.C., Hodges, K.V., and Royden, L.H., 1987, Geology of Panamint Valley-Saline Valley pull-apart system, California: Palinspastic evidence for low-angle geometry of a Neogene range-boundary fault: Journal of Geophysical Research, v. 92, no. B10, p. 10,422-10,426.

Carr, M.D., and Monsen, S.A., 1988, A field trip guide to the geology of Bare Mountain, in Weide, D.L., and Faber, M.L., eds., This Extended Land, Geological Journeys in the Southern Basin and Range: Geological Society of America Cordilleran Section Field Trip Guidebook, p. 5057.

Carr, M.D., Waddell, S.J., Vick, G.S., Stock, J.M., Monsen, S.A., Harris, A.G., Cork, B.W., and Byers, F.M., 1986, Geology of drill hole UE-25p\#1: A test hole into pre-Tertiary rocks near Yucca Mountain, southern Nevada: U.S. Geological Survey Open-File Report 86-175, 87 p.

Carr, W.J., 1982, Volcano-tectonic history of Crater Flat, southwestern Nevada, as suggested by new evidence from drill hole USW VH-1 and vicinity: U.S. Geological Survey Open-File Report 82-457, 23 p.

-..- 1984, Regional structural setting of Yucca Mountain, southwestern Nevada, and late Cenozoic rates of tectonic activity in part of the southwestern Great Basin: U.S. Geological Survey Open-File Report 84-854, 109 p.

-..- 1988, Volcanic-tectonic setting of Yucca Mountain and Crater Flat, southwestern Nevada, in Carr, M.D., and Yount, J.C., eds., Geologic and hydrologic investigations of a potential nuclear waste disposal site at Yucca Mountain, southern Nevada: U.S. Geological Survey Bulletin 1790, p. 35-50. 
-..- -..- 1990, Styles of extension in the Nevada Test Site region, southern Walker Lane Belt: an integration of volcano-tectonic and detachment fault models, in Wernicke, B.P., ed., Basin and Range extensional tectonics near the latitude of Las Vegas, Nevada: Boulder, Colorado, Geological Society of America Memoir 176, p. 283-303.

Carr, W.J., Byers, F.M., Jr., and Orkild, P.P., 1986, Stratigraphic and volcano-tectonic relations of Crater Flat Tuff and some older volcanic units, Nye County, Nevada: U.S. Geological Survey Professional Paper 1323, 28 p.

Christiansen, R.L., and Lipman, P.W., 1965, Geologic map of the Topopah Spring NW quadrangle, Nye County, Nevada: U.S. Geological Survey Geologic Quadrangle Map GQ-444, scale $1: 24,000$.

Cornwall, H.R., 1972, Geology and mineral deposits of southern Nye County, Nevada: Nevada Bureau of Mines and Geology, Bulletin 77, 49 p.

Craig, R.W., and Johnson, K.A., 1984, Geohydrologic data for test well UE-25p\#1, Yucca Mountain area, Nye County, Nevada: U.S. Geological Survey Open-File Report 84$450,63 \mathrm{p}$.

Crowe, B.M., Morley, R., Wells, S., Geissman, J., McDonald, E., McFadden, L., Perry, F., Murrell, M., Poths, J., and Forman, S., 1992, The Lathrop Wells volcanic center: status of field and geochronology studies: American Nuclear Society, Proceedings of the Third Annual International Conference on High-Level Radioactive Waste Management, v. 2, p. 1997-2013.

Crowe, B.M., Perry, F., Geissman, J., McFadden, L., Wells, S., Murrell, M., Poths, J., Valentine, G.A., Bowker, L., Finnegan, K., 1995, Status of volcanism studies for the Yucca Mountain Site Characterization Project: Los Alamos National Laboratory Report LA-12908-MS, available from National Technical Information Service, U.S. Department of Commerce, 5285 Port Royal Road, Springfield, VA 22161, 380 p.

Crowe, B.M., Vaniman, D.J., and Carr, W.J., 1983, Status of volcanic hazard studies for the Nevada Nuclear Waste Storage Investigations: Los Alamos National Laboratory Report LA9325-MS.

Crowe, B.M., Wohletz, K.H., Vaniman, D.T., Gladney, E., and Bower, N., 1986, Status of volcanic hazard studies for the Nevada Nuclear Waste Storage Investigations: Los Alamos National Laboratory Report LA-9325-MS, v. II, 101 p.

deVoogd, B., Serpa, L., Brown, L., Hauser, E., Kaufman, S., Oliver, J., Troxel, B.W., Willemin, J., and Wright, L.A., 1986, Death Valley bright spot: A midcrustal magma body in the southern Great Basin, California?: Geology, v. 14, p. 64-67.

Frischknecht, F.C., and Raab, P.V., 1984, Time-domain electromagnetic soundings at the Nevada Test Site, Nevada: Geophysics, v. 49, no. 7, p. 981-992. 
Hamilton, W., 1987, Crustal extension in the Basin and Range Province, southwestern United States, in Coward, M.P., Dewey, J.F., and Hancock, P.L., eds., Continental Extensional Tectonics: Geological Society Special Publication No. 28, Blackwell Scientific Publications, Oxford, England, p. 155-176.

Healey, D. L., 1968, Application of gravity data to geological problems at the Nevada Test Site, in Eckel, E. B., ed., Nevada Test Site: Geological Society of America Memoir 110, p. 147-156.

Healey, D.L., Clutsom, F.G., and Glover, D.A., 1984, Borehole gravity meter surveys in drill holes USW G3, UE-25p\#1, and UE-25 C\#1, Yucca Mountain area, Nevada: U.S. Geological Survey Open-File Report 84-672, 16 p.

Healey, D.L., and Miller, C.H., 1972, Gravity survey of the Amargosa Desert area of Nevada and California: U.S. Geological Survey Report USGS-474-136, 32 p.; available only from U.S. Department of Commerce, National Technical Information Service, Springfield, VA 22161.

Hildenbrand, T.G., Rogers, A.M., Oliver, H.W., Harmsen, S.C., Nakata, J.K., and Carr, M.D., 1988, 1:2,500,000-scale gravity, aeromagnetic, terrain, contemporary seismicity, and quaternary fault maps of the southern Great Basin, in Carr, M.D. and Yount, J.C., eds., Geologic and hydrologic investigations of a potential nuclear waste disposal site at Yucca Mountain, Southern Nevada: U.S. Geological Survey Bulletin 1790, p. 3-21 + 2 transparent plates.

Hoover, D.B., Chornack, M.P., Nervick, K.H., and Broker, M.M., 1982, Electrical studies at the proposed Wahmonie and Calico Hills nuclear waste sites, Nevada Test Site, Nye County, Nevada: U.S. Geological Survey Open-File Report 82-466, 91 p.

Hunt, C.B., and Mabey, D.R., 1966, Stratigraphy and structure, Death Valley, California: U.S. Geological Survey Professional Paper 494-A, 162 p.

King, P. B., and Beikman, H. M., 1974, Geological map of the United States (exclusive of Alaska and Hawaii): U.S. Geological Survey, scale 1:2,500,000.

Lipman, P.W., and McKay, E.J., 1965, Geologic map of the Topopah Spring SW quadrangle, Nye County, Nevada: U.S. Geological Survey Geologic Quadrangle Map GQ-439, scale 1:24,000.

Manastersky, Richard, 1988, The 10,000-year test: Science News, v. 133, no. 9, p. 139-141.

Muller, C.H., and Healey, D.L., 1986, Gravity interpretation of Frenchman Flat and vicinity, Nevada Test Site: U.S. Geological Survey Open-File Report 86-211, 36 p.

Muller, D.C., and Kibler, J.E., 1984, Preliminary analysis of geophysical logs from drill hole UE25p\#1, Yucca Mountain, Nye County, Nevada: U.S. Geological Survey Open-File Report 84649,14 p., 1 plate. 
National Academy of Sciences Committee on Radioactive Waste Management, 1978, Geological criteria for repositories for high-level radioactive wastes: National Academy of Sciences, Washington, D.C., 19 p.

Noble, L.F., 1941, Structural features of the Virgin Spring area, Death Valley, California:

Geological Society of America Bulletin, v. 52, p. 941-1000.

Oliver, H.W., 1987, Introduction to Special Sections on geophysical investigations of proposed waste disposal sites: Journal of Geophysical Research, v. 92, no. B8, p. 7,783-7,785.

1984, Geophysical investigations in the Nevada Nuclear Waste Storage Investigations program: U.S. Geological Survey Quality Assurance Manual, Nuclear Waste Management, v. 1, Procedure NWM-USGS-UTP-02, 8 p.

Oliver, H.W., Dixon, G.L., and Carr, W.J., 1982, Geophysical and geological characterization of Yucca Mountain and vicinity, Nevada [abs.]: EOS (Transactions), American Geophysical Union, v. 63 , no. 45 , p. 1,099 .

Oliver, H.W., and Fox, K.F., 1993, Structure of Crater Flat and Yucca Mountain southwestern Nevada, as inferred from gravity data: American Nuclear Society Proceedings of the Fourth Annual International Conference on High-Level Radioactive Waste Management, v. 2 p. 18121817.

Oliver, H.W., Hardin, E.L., and Nelson, P.H., eds., 1990, Status of data, major results, and plans for geophysical activities, Yucca Mountain Project: U.S. Department of Energy Report YMP 90-38, 236 p.

Ponce, D.A., and Hanna, W.F., 1982, Preliminary appraisal of gravity and magnetic data at Syncline Ridge, western Yucca Flat, Nevada Test Site, Nye County, Nevada: U.S. Geological Survey Open-File Report 82-931, 19 p.

Ransome, F.L., Emmons, W.H., and Garrey, G.H., 1910, Geology and ore deposits of the Bullfrog district, Nevada: U.S. Geological Survey Bulletin 407, 130 p.

Rogers, A.M., Harmsen, S.C., Carr, W.J., and Spence, W., 1983, Southern Great Basin seismological data report for 1981 and preliminary data analysis: U.S. Geological Survey Open-File Report 83-669, 240 p.

Sawyer, David A., Fleck, R.J., Lanphere, M.A., Warren, R.G., Broxton, D.E., Hudson, Mark R., 1994, Episodic caldera volcanism in the Miocene southwestern Nevada volcanic field: Revised stratigraphic framework, ${ }^{40} \mathrm{Ar} /{ }^{39} \mathrm{Ar}$ geochronology, and implications for magmatism and extension: Geological Society of America Bulletin, v. 106, p. 1304-1318. 
Scott, R.B., 1990, Tectonic setting of Yucca Mountain, southwest Nevada, in Wernicke, B.P., ed., Basin and Range extensional tectonics near the latitude of Las Vegas, Nevada: Boulder, Colorado, Geological Society of America Memoir 176, p. 251-282.

Scott, R.B., and Bonk, Jerry, 1984, Preliminary geologic map of Yucca Mountain with geologic sections, Nye County, Nevada: U.S. Geological Survey Open-File Report 84-494, scale $1: 12,000$.

Simonds, F. William, 1995, Miocene/Paleozoic contact at the Calico Hills, Nye County, Nevada, in Whitney, J.W., and Coates, M.M., eds., Tectonic characterization of Yucca Mountain, Nevada-a potential geologic repository for high-level radioactive waste: U.S Geological Survey Circular, Yucca Mountain Project Tectonics Workshop, Estes Park, Colorado, in press.

Snyder, D.B., and Carr, W.J., 1984, Interpretation of gravity data in a complex volcano-tectonic setting, southwestern Nevada: Journal of Geophysical Research, v. 89, no. B12, p. 10,19310,106 .

Snyder, D.B, and Oliver, H.W., 1981, Preliminary results of gravity investigations of the Calico Hills, Nevada Test Site, Nye County, Nevada: U.S. Geological Survey Open-File Report 81$101,41 \mathrm{p}$.

Stewart, J. H., 1988, Tectonics of the Walker Lane Belt, western Great Basin: Mesozoic and Cenozoic deformation in a zone of shear, in Ernst, W. G., ed., Metamorphism and crustal evolution of the western United States, Rubey Volume VII: Prentice Hall, Englewood Cliffs, New Jersey, p. 83-713.

Stock, J.M., and Healey, J.H., 1988, Stress field at Yucca Mountain, in Carr, M.D., and Yount, J.C., eds., Geologic and hydrologic investigations of a potential nuclear waste disposal site at Yucca Mountain, southern Nevada: U.S. Geological Survey Bulletin 1790, p. 87-94.

Streitz, Robert, and Stinson, M.C., 1974, Geologic map of California, Death Valley sheet: California Division of Mines and Geology, scale 1:250,000.

Swadley, WC, Hoover, D.L., and Rosholt, J.N., 1984, Preliminary report on late Cenozoic stratigraphy and faulting in the vicinity of Yucca Mountain, Nye County, Nevada: U.S. Geological Survey Open-File Report 84-788, 42 p.

U.S. Department of Energy, 1986, Environmental assessment--Yucca Mountain site, Nevada Research and Development Area, Nevada: U.S. Department of Energy, Office of Civilian Radioactive Waste Management, Washington, D.C., Report DOE/RW-0073, 816 p.

-.- 1988, Site characterization plan--Yucca Mountain site, Nevada Research and Development Area, Nevada: U.S. Department of Energy, Office of Civilian Radioactive Waste Management, Washington, D.C., Report DOE/RW-0199, 8 volumes. 
U.S. Geological Survey, 1984, A summary of geologic studies through 1983 of a potential highlevel radioactive waste disposal site at Yucca Mountain, southern Nye County, Nevada: U.S. Geological Survey Open-File Report 84-792, 103 p. text +51 illus.

U.S. Nuclear Regulatory Commission, 1983, Disposal of high-level radioactive wastes in geologic repositories: Federal Register, v. 48, no. 120, Rules and Regulations, 10CFR Part 60, p. 28194-28229.

Winograd, I.J., and Thordarson, William, 1975, Hydrogeologic and hydrochemical framework, south-central Great Basin, Nevada-California, with special reference to the Nevada Test Site: U.S. Geological Survey Professional Paper 712-C, 126 p.

Wynn, J.C., and Roseboom, E.H., 1987, Role of geophysics in identifying and characterizing sites for high-level nuclear waste repositories: Journal of Geophysical Research, v. 92, no. B8, p. 7,787-7,796. 


\title{
MAJOR RESULTS OF GEOPHYSICAL INVESTIGATIONS AT YUCCA MOUNTAIN AND \\ VICINITY, SOUTHERN NEVADA
}

\section{CHAPTER 2: GRAVITY INVESTIGATIONS}

\author{
By D.A. Ponce and H.W. Oliver
}

\section{INTRODUCTION}

As part of a geoscientific effort to evaluate the Nevada Test Site and vicinity for favorable areas for the storage of commercial spent nuclear fuel and high-level radioactive waste, gravity investigations were begun in about 1977 and have been used to characterize the general geologic and tectonic setting. Gravity studies are particularly useful for determining (1) the general subsurface configuration of pre-Tertiary bedrock or basement, (2) the location and extent of concealed or unrecognized faults, (3) the location and extent of calderas and plutons, and (4) tectonic stability. Gravity methods can reveal shallow as well as deep features wherever rocks of different densities are juxtaposed. Such shallow features include faults and edges of calderas. Gravity data can also reveal deep undulations in the base of the crust, such as those which occur at a depth of about $33 \mathrm{~km}$ beneath Yucca Mountain.

\section{SUMMARY OF PREVIOUS WORK}

Gravity studies at the Nevada Test Site and vicinity initially were made during 1957-1978 to help define the configuration of the pre-Cenozoic basement under Frenchman and Yucca Flats, Pahute Mesa (fig. 1.1, chapter 1, this volume; Healey, 1968), and the Nevada Test Site in general (Healey and Miller, 1979). Much of this work served as the basis for more detailed studies, begun in 1.977, in a search for a possible site within the Nevada Test Site for the storage of radioactive waste.

A detailed geophysical investigation was begun in 1977 at Syncline Ridge (fig. 1.3) that utilized gravity as well as magnetic, seismic, and electrical methods (Hoover and others, 1982b; Ponce and Hanna, 1982). Although Syncline Ridge was believed to be a relatively undisturbed synclinal structure, geophysical data revealed that the area was structurally complex. These studies supported geological studies (Hoover and Morrison, 1980) and in addition indicated that faulting was more extensive, displacements were larger than previously known, and that the argillic host-rock lacked homogeneity.

Early gravity surveys in the Timber Mountain area, in particular, the Pahute Mesa and Buckboard Mesa areas (fig. 1.6), included about 765 stations that were used by Healey and Miller (1979) to investigate the configuration of buried pre-Cenozoic rocks. These studies revealed that the Timber Mountain area lies within a broad circular gravity high which correlates with an arcuate intrusive body and that adjacent gravity lows are associated with moat areas of the Timber Mountain caldera. A two-dimensional gravity model of Timber Mountain by Healey and Miller (1979) indicated that volcanic rocks were about 2,700 to 3,700 m thick. About 940 
subsequent gravity measurements by D. L. Healey (written commun., 1979) were supplemented by over 300 additional measurements to search for concealed granitic plutons (Kane and others, 1981). According to Kane and others (1981), gravity data in the southern part of Timber Mountain suggest that this area may be underlain by intrusive rocks similar to those exposed along the southeast side of Timber Mountain, and further, that the northern part of the Timber Mountain caldera truncates the southern edge of the older Silent Canyon caldera. Also, Kane and others (1981) speculated that the deformation associated with volcanism in the region has taken place along a system of linear faults that combine to give a curvilinear appearance to the regional structure. If gravity gradients along the eastern and western sides of Timber Mountain are remnants of gradients associated with the original Silent Canyon caldera, then the caldera might extend substantially southward.

Because of proximity to weapons testing areas, earlier studies in these areas were discontinued and subsequent studies were focused in the southwest quadrant of the Nevada Test Site (U.S. Department of Energy, 1986). One of these sites was Wahmonie (fig. 1.3), where aeromagnetic data indicated the presence of granitic rocks (G.D. Bath, oral commun., 1980). Detailed gravity and magnetic data obtained in 1979-1981 (Ponce, 1981, 1984) revealed large, positive, and coincident gravity and magnetic anomalies near Wahmonie. Two smaller local magnetic anomalies, along a magnetic prominence extending from the main anomaly, directly correlated with two small exposures of granitic rocks. This suggested that the main anomaly was also associated with a granitic intrusion. Gravity modeling and other geophysical data suggested that Wahmonie was underlain by granitic rocks, that the upper parts of the intrusion were altered or fractured or both, and that there was a possibility that the causative body might represent a magnetic and altered argillic member of the Eleana Formation (Mississippian to Upper Devonian).

A study similar to that at Wahmonie was undertaken at Calico Hills in 1979 (Snyder and Oliver, 1981). The combination of hydrothermal alteration, structural doming of Calico Hills, and an aeromagnetic anomaly suggested that the area was underlain by a shallow Tertiary granitic intrusion (Maldonado and others, 1979; G.D. Bath, oral commun., 1980). Two-dimensional modeling of an elliptical gravity high, centered over exposed Paleozoic rocks, indicated that the anomaly could be attributed entirely to a density contrast between the Paleozoic rocks and the overlying Tertiary volcanic rocks, but the model did not preclude the existence of an intrusion. Moreover, a drill hole in the central part of Calico Hills revealed that the inferred intrusion, if present, must be deeper than $760 \mathrm{~m}$, and that at least locally, the argillic facies of the Eleana Formation is strongly magnetic, containing 1 to $3 \%$ magnetite. Although much of the magnetic anomaly at Calico Hills could be attributed to magnetic rocks of the Eleana Formation, an intrusion may exist at a depth too great to be considered for a repository.

\section{DENSITY DATA}

Rock densities at the Nevada Test Site and vicinity can be separated into three broad groups: pre-Cenozoic sedimentary rocks and intrusive rocks with an average density of about $2.67 \mathrm{~g} / \mathrm{cm}^{3}$, Cenozoic volcanic rocks with a density of about $2.4 \mathrm{~g} / \mathrm{cm}^{3}$, and nonwelded and partially welded ash-flow tuffs and alluvium with a density of about $2.0 \mathrm{~g} / \mathrm{cm}^{3}$. There are three primary sources of rock density information at the Nevada Test Site and vicinity: rock samples 
(including core samples), borehole gravity-meter surveys, and borehole density logs. A brief summary of bulk density data of rock samples, unless otherwise specified, is given below for the three major rock groups.

Density data from pre-Cenozoic rocks are available from several areas of the Nevada Test Site and vicinity. Density measurements on undivided Paleozoic rocks from the Nevada Test Site and vicinity average $2.67 \mathrm{~g} / \mathrm{cm}^{3}$ (Healey, 1983). Density data on intrusive rocks include measurements on samples of quartz monzonite and granodiorite from the Climax Stock which have an average density of $2.68 \mathrm{~g} / \mathrm{cm}^{3}$ (Izett, 1960) and $2.64 \mathrm{~g} / \mathrm{cm}^{3}$ (F. N. Houser, written commun., 1962), respectively. An average density of $2.65 \mathrm{~g} / \mathrm{cm}^{3}$ (Ponce, 1984) was determined on 23 samples of granodiorite from Wahmonie.

Volcanic rocks vary widely in density partly due to their degree of welding. Keller (1959) reported an average density of 2.18 for 31 tuff samples from the Rainier Mesa Tuff (Sawyer and others, 1994) of the Timber Mountain Group. Data from 91 Cenozoic volcanic samples from the Timber Mountain area have an average saturated bulk density of $2.08 \mathrm{~g} / \mathrm{cm}^{3}$ (Heinrichs, 1963). Johnson and Ege (1964) reported numerous density measurements made on drill core samples obtained in the vicinity of Wahmonie. These samples were predominantly dacite porphyry yielding an average density of $2.27 \mathrm{~g} / \mathrm{cm}^{3}$. Healey (1968) reported that the average density of alluvium and nonwelded tuff averages $1.94 \mathrm{~g} / \mathrm{cm}^{3}$ and that partially welded to welded tuff averages $2.36 \mathrm{~g} / \mathrm{cm}^{3}$. Seventy-seven undivided volcanic rocks at the Nevada Test Site had an average density of $2.22 \mathrm{~g} / \mathrm{cm}^{3}$ (Ponce, 1984). Ponce (1984) listed average densities for volcanic rocks at Wahmonie where 17 samples of rhyolite averaged $2.31 \mathrm{~g} / \mathrm{cm}^{3}$, nine samples of intrusive rhyolite averaged $2.57 \mathrm{~g} / \mathrm{cm}^{3}, 27$ samples of rhyodacite averaged $2.58 \mathrm{~g} / \mathrm{cm}^{3}$, and eight samples of andesite averaged $2.66 \mathrm{~g} / \mathrm{cm}^{3}$.

Samples of Quaternary alluvium have a wide range in density that is partly dependent on the lithology of the source rocks. In the Yucca Flat area, the average density of $2,225 \mathrm{~m}$ of alluvium was $2.01 \mathrm{~g} / \mathrm{cm}^{3}$ as measured in several drill holes by density logs and borehole gravity meter (Healey, 1970). Ponce (1981) summarized density data from four sets of alluvial samples that yielded an average density of $1.46,1.58,1.66$, and $1.92 \mathrm{~g} / \mathrm{cm}^{3}$. Healey and Kibler (written commun., 1987) compiled densities of alluvium from 12 drill holes on the Nevada Test Site that yielded an average of $1.89 \mathrm{~g} / \mathrm{cm}^{3}$.

Although borehole gravity meters are essentially logging tools, their results are included here because of their application to gravity interpretation. Borehole gravity-meter surveys provide an independent measurement of bulk density, and because they measure a larger volume of rocks than do conventional logging tools, they reflect the density of rocks surrounding the drill hole. Structure adjacent to the borehole and the density of the overburden can also be determined using borehole gravity surveys along with gamma-gamma density logs. Robbins (1980) compiled an extensive bibliography, which included abridged abstracts, of subsurface gravimetry collected prior to 1980 . Robbins and others (1982) reported on the results from drillhole USW H-1, on Yucca Mountain. The data show an increase in density of volcanic rocks from $2.23 \mathrm{~g} / \mathrm{cm}^{3}$ near the surface to about $2.50 \mathrm{~g} / \mathrm{cm}^{3}$ at a depth of $1,792 \mathrm{~m}$. Healey and others $(1984,1986)$ reported on the results of four drill holes on Yucca Mountain. Borehole gravity data from the deepest of the four drill-holes (UE-25 p\#1), on the east side of Yucca Mountain, 
show an increase in density of volcanic rocks from about $1.92 \mathrm{~g} / \mathrm{cm}^{3}$ to a value of about 2.67 $\mathrm{g} / \mathrm{cm}^{3}$ at a depth of $1,244 \mathrm{~m}$, and that Paleozoic rocks at a depth of $1,792 \mathrm{~m}$ have a density of $2.80 \mathrm{~g} / \mathrm{cm}^{3}$. According to Healey (1968), the increase in density with depth is a function of the lithology of the volcanic rocks and does not imply compaction from loading. However, we suspect that rocks of similar lithology show an increase in density with depth that is a function of compaction.

\section{REGIONAL GRAVITY DATA COMPLATIONS}

Concurrent with the specific site studies, existing gravity data within the Nevada Test Site and to a radius of $100 \mathrm{~km}$ were compiled as required by early drafts of the guidelines for the disposal of nuclear waste in geologic repositories by the U.S. Nuclear Regulatory Commission (1983). These data were released as Bouguer gravity maps of the four 1-by 2-degree quadrangles at a scale of 1:250,000 that describe the Nevada Test Site and vicinity as follows: Las Vegas (Kane and others, 1979), Death Valley (Healey and others, 1980), Goldfield (Healey and others, 1980), and Caliente (Healey and others, 1981). Gravity data for the southwestern part of the NTS and vicinity were released by Jansma and others (1982) and included gravity and magnetic data along three profiles across Yucca Mountain. The data from the four 1:250,000scale maps have since been recompiled and extended south to $35^{\circ} 30^{\prime} \mathrm{N}$, north to $38^{\circ} 30^{\prime} \mathrm{N}$, and west to $118^{\circ} 30^{\prime} \mathrm{W}$ using subsets of the gravity data releases for California (Snyder and others, 1981) and Nevada (Saltus, 1988). A Bouguer gravity map of the southern Great Basin is shown (fig. 2.1) with the site area plotted for perspective. A detailed complete Bouguer gravity anomaly map of the Nevada Test Site and vicinity at a scale of 1:100,000, based on about 16,000 gravity stations (Healey and others, 1988), and documentation for these gravity stations (Harris and others, 1989) are available.

Although regional Bouguer gravity maps are useful for interpreting or modeling smalland large-scale features, the longer-wavelength components of Bouguer gravity anomalies correlate inversely to topography. This correlation to topography produces a regional gravity gradient that may influence local anomalies. At the Nevada Test Site and vicinity, this effect is a function of the general increase in average topographic elevation to the northeast (Oliver and others, 1982). Thus, it is desirable to remove this effect by making a correction for topography by using an isostatic model which assumes that topographic loads are supported at depth by compensating masses. Isostatic corrections were made using a procedure by Simpson and others (1983), based on a model of Airy-Heiskanen local compensation with the following parameters: an assumed upper crustal density of $2.67 \mathrm{~g} / \mathrm{cm}^{3}$, a crustal thickness of $25 \mathrm{~km}$, and a density contrast between the upper crust and lower mantle of $0.4 \mathrm{~g} / \mathrm{cm}^{3}$. Although other isostatic model parameters or other isostatic models could be used, differences in the resulting isostatic corrections are small compared to the total correction (Jachens and Griscom, 1985). Because the main features on isostatic gravity maps produced by various models appear similar, the application of some type of isostatic correction is more important than the character of the actual model (Simpson and others, 1986). Isostatic residual gravity anomalies enhance short- to moderate-wavelength anomalies caused by bodies in the upper parts of the crust. 

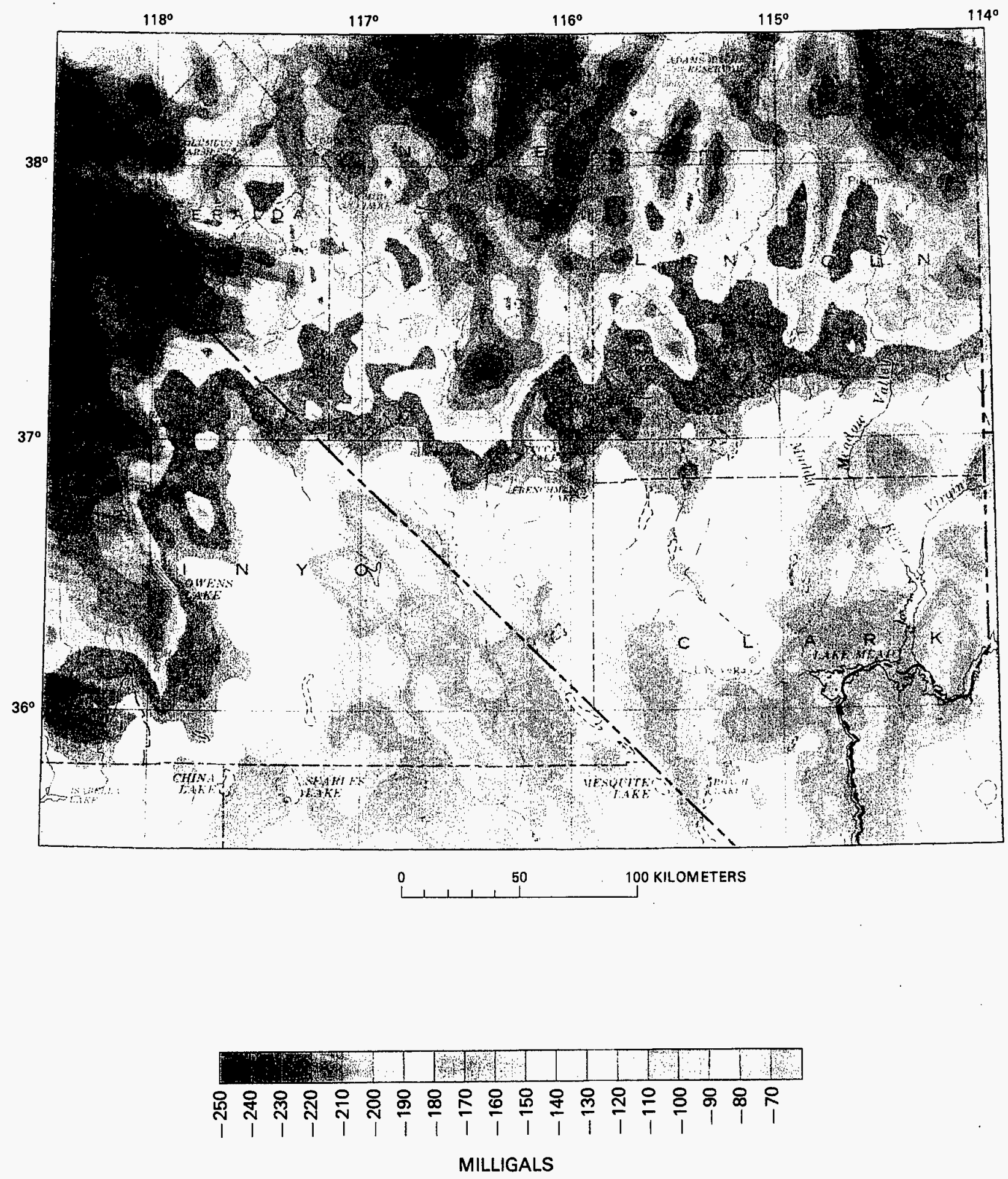

Figure 2.1. Complete Bouguer gravity map of the southern Great Basin using a Bouguer reduction density of 2.67 $\mathrm{g} / \mathrm{cm}^{3}$. Modified from Hildenbrand and others (1988). 
A preliminary isostatic residual gravity map of the area within a radius of $100 \mathrm{~km}$ from Yucca Mountain was released by the U.S. Geological Survey at a scale of 1:500,000 (1984, fig. 2). An isostatic residual gravity map of the southern Great Basin is shown in figure 2.2 (modified from Hildenbrand and others, 1988). A detailed isostatic gravity map of the Nevada Test Site and vicinity at a scale of $1: 100,000$ is available (Ponce and Harris, 1988).

\section{YUCCA MOUNTAIN AND VICINITY}

Regional gravity studies of Yucca Mountain and Crater Flat were included in reports on the Amargosa Desert and Timber Mountain areas by Healey and Miller $(1971,1979)$. They described a gravity anomaly associated with Yucca Mountain, attributed it to low-density volcanic rocks, and initially suggested that volcanic rocks in Crater Flat were about 1,700 to $2,400 \mathrm{~m}$ thick. Healey and Miller later (1979) estimated that these rocks were about 2,000 to $2,400 \mathrm{~m}$ thick. These estimates were based on very limited gravity station control. Along the gravity profile, only one gravity station was available over the center of Crater Flat and only one was available at each border of Crater Flat, yielding a gravity amplitude of $-40 \mathrm{mGal}$.

As early as 1979, additional regional gravity data were collected at Yucca Mountain and vicinity to supplement the existing regional coverage. The gravity coverage in the Yucca Mountain area is still somewhat regional (fig. 2.3). Many of the major isostatic gravity anomalies of Yucca Mountain and vicinity (fig. 2.2) have been discussed by the U.S. Geological Survey (1984), Snyder and Carr (1984), and Harris and others (1986). The gravity anomalies most pertinent to the characterization of Yucca Mountain are (1) the northwestward decrease of about $20 \mathrm{mGal}$ across Yucca Mountain (marked "Y" in fig. 2.2), (2) the sharp westward increase in gravity of about $30 \mathrm{mGal}$ at the west side of Crater Flat (CF, fig. 2.2), and (3) the configuration and extent of the gravity low to the north of Yucca Mountain centered over the Silent Canyon caldera (SC, fig. 2.2), reaching a negative value of about $-60 \mathrm{mGal}$. This major gravity feature over the Silent Canyon caldera is clearly associated with Cenozoic rocks and is similar in extent and amplitude to gravity lows over the Yellowstone caldera (Evans and Oliver, 1987, Oliver and Carle, 1988) and Long Valley caldera (Oliver and Robbins, 1982; Jachens and Roberts, 1985).

The northwestward gravity decrease across Yucca Mountain was modeled by Snyder and Carr $(1982 ; 1984)$ as a 3,000- to 4,000 -m-deep caldera extending from the repository area to Bare Mountain (see fig. 1.2). Snyder and Carr's models included both two and three-dimensional analyses and differ from Healey and Miller's (1979) models by the following: detailed gravity data that included at least 13 gravity stations over Crater Flat along each of three two-dimensional models, a gravity low of about $44 \mathrm{mGal}$, a multi-layered geologic model, and (for the threedimensional model) a linear density function based on borehole log measurements. Because density information is lacking below a depth of about $2 \mathrm{~km}$, an accurate tuff thickness is difficult to determine. Seismic refraction studies by Hoffman and Mooney (1983) indicated a depth to basement of about $3,200 \mathrm{~m}$, supporting the gravity results. Gravity modeling also predicted a rise in basement under the eastern part of Yucca Mountain to a depth of $1,100 \mathrm{~m}$ that was verified by 

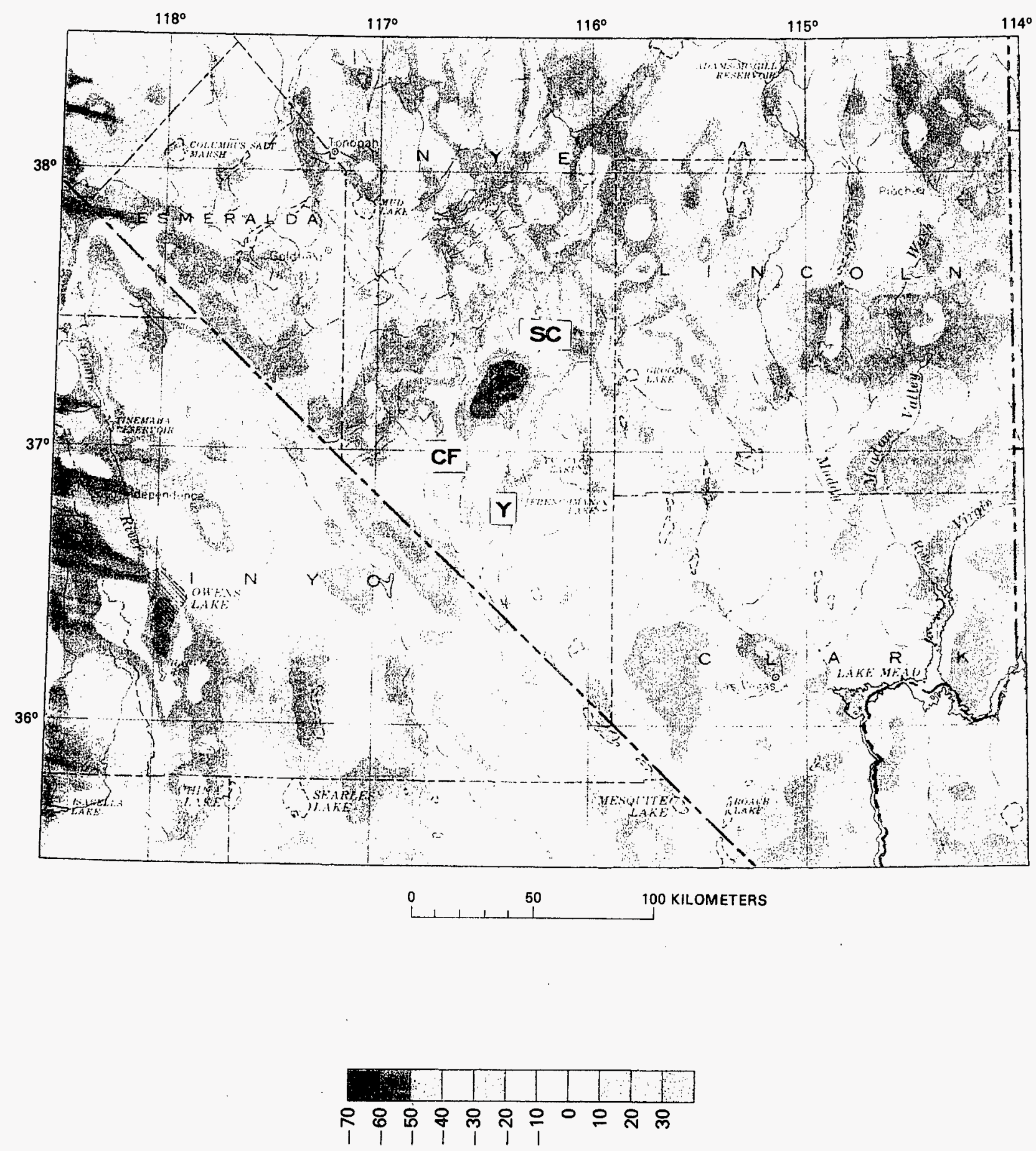

MILLIGALS

Figure 2.2. - Isostatic residual gravity map of the southern Great Basin reduced with an assumed upper crust density of $2.67 \mathrm{~g} / \mathrm{cm}^{3}$, a crustal thickness of $25 \mathrm{~km}$, and a density contrast between the upper crust and lower mantle of $0.4 \mathrm{~g} / \mathrm{cm}^{3}$. Modified from Hildenbrand and others (1988). Symbols: CF, Crater Flat; SC, Silent Canyon caldera; Y, Yucca Mountain. 


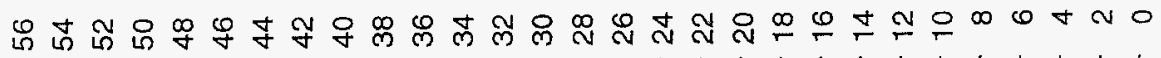

ह
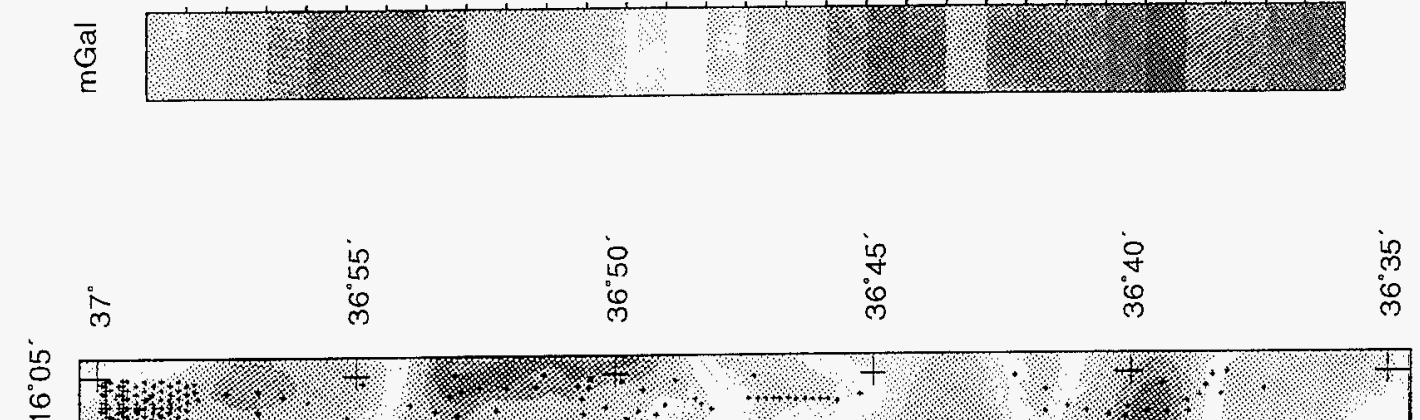

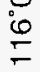

:

视
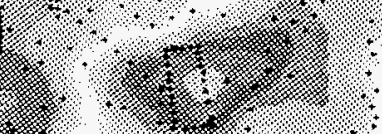

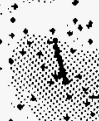

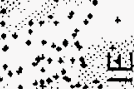

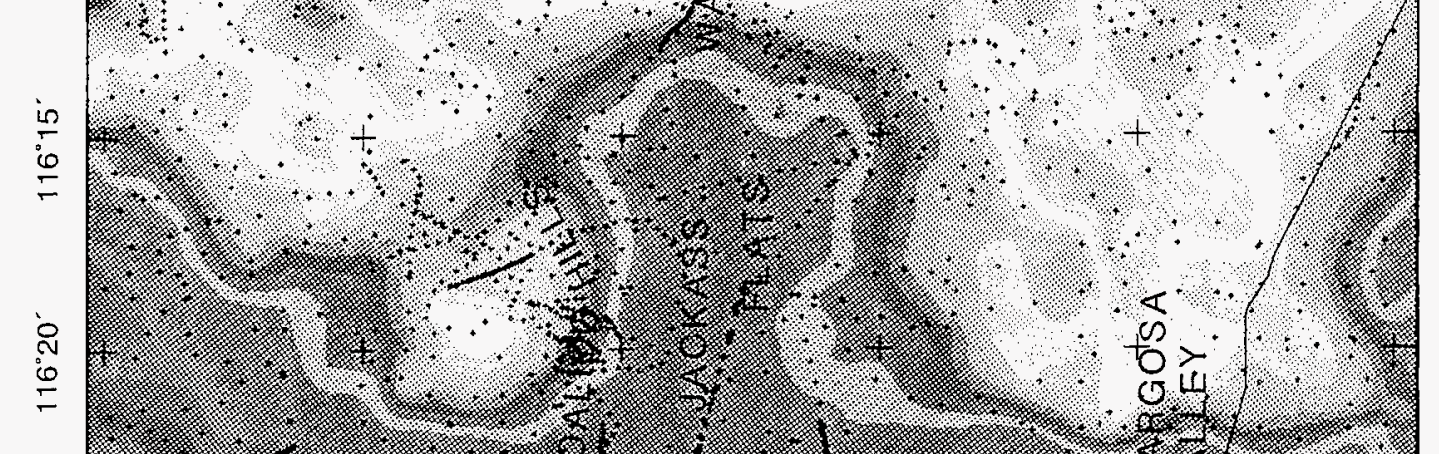

$\stackrel{2}{\mathscr{0}}$

in

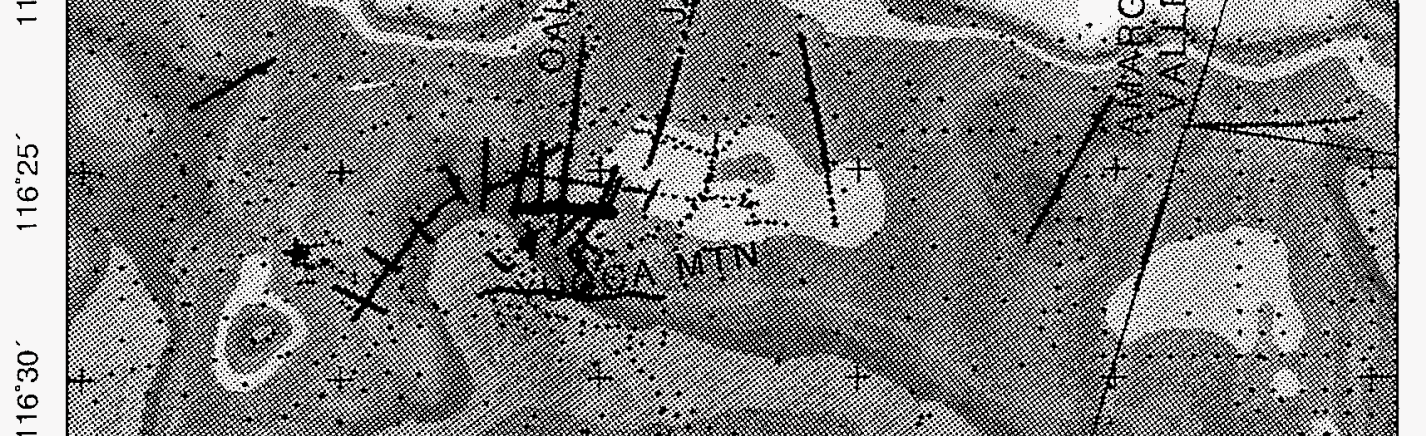

W

$\stackrel{\infty}{\circ}$

in
0
0
0

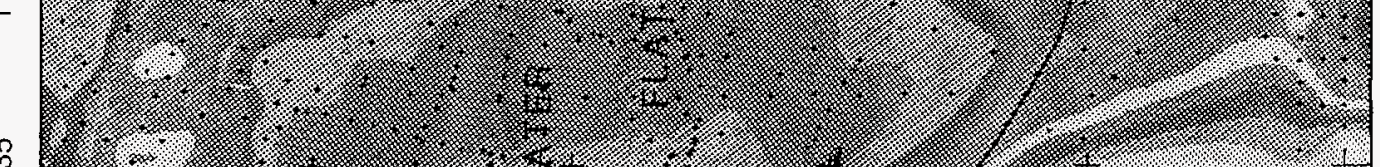

in

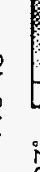

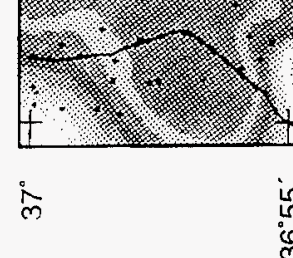

?

$\begin{array}{ll}i n & \dot{0} \\ 0 & 0 \\ 0 & 0\end{array}$

$\begin{array}{ll}i & \text { is } \\ 0 & \text { in } \\ 0 & 0\end{array}$ 
drill-hole UE-25 $\mathrm{p} \# 1$ which encountered Paleozoic rocks at about 1,244 $\mathrm{m}$ below the surface (Carr and others, 1986).

A conceptually different model for the Yucca Mountain-Crater Flat region, suggested by K. F. Fox (written commun., 1986), is illustrated in figures 2.4 and 2.5 which show a relatively smooth base of the volcanic pile below Yucca Mountain. In this model, there is an east-dipping "master" detachment fault near the west edge of Bare Mountain, a listric normal fault forming the east face of Bare Mountain and merging with the master detachment fault at depth, and a westdipping Yucca Mountain detachment terminating below Crater Flat at its intersection with the master detachment. At present, the inherent ambiguity in the gravity method does not allow differentiation between the caldera or the detachment model.

\section{GRA VITY AND SEISMIC DATA}

Gravity data have been interpreted along three of the five seismic refraction profiles in the vicinity of Yucca Mountain: Yucca Mountain, Beatty, and Amargosa profiles (see Mooney and Schapper, this volume, fig. 6.1). Snyder and Carr's (1984) gravity model from Bare Mountain, across Yucca Mountain, and extending to Jackass Flats is nearly coincident with the Yucca Mountain seismic refraction profile. The gravity model correlates well with the seismic-refraction model and is constrained by geologic and drill-hole data. In particular, the gravity model is in better agreement with the depth to pre-Cenozoic rocks in drill hole UE-25 p\#1 than is the seismic interpretation (Mooney and Schapper, this volume). Snyder and Carr (1984) interpreted a deep volcanic depression extending from Crater Flat to central Yucca Mountain and a rise of preCenozoic rocks in the eastern part of Yucca Mountain.

The Beatty profile extends from the Bullfog Hills, along the northernmost part of Bare Mountain, and into Crater Flat (Mooney and Schapper, this volume, fig. 6.1). A preliminary seismic and gravity interpretation made by Ackermann and others (1988) suggested that a lowangle fault or detachment surface, exposed in the Grapevine Mountains, may correspond to a modeled layer with a velocity of $6.3 \mathrm{~km} / \mathrm{s}$ and a density of $2.74 \mathrm{~g} / \mathrm{cm}^{3}$. This layer possibly continues east to Crater Flat.

Detailed gravity data were collected along a seismic-reflection traverse (Brocher and others, 1990) that was coincident with a part of the Amargosa seismic-refraction traverse described and interpreted by Mooney and Schapper (this volume). A gravity model by Brocher and others (1990) was based on the refraction model and primarily differs in the shape of the basin fill-basement interface. The gravity model also indicated narrow basement highs that were not detected in the refraction data but were later detected in the reflection data. Near the western end of the reflection traverse, about $6.4 \mathrm{~km}$ south of Lathrop Wells, gravity data indicate the presence of a major west-dipping normal fault, bounding the basin, that extends to a depth of several kilometers. About $3.2 \mathrm{~km}$ to the east of this fault, gravity data indicate another high in the basement rocks that correlates with seismic data. Electrical data also detected the presence of a major fault that was inferred to represent the eastern boundary of the Ash Meadows groundwater system (Hoover and others, 1982a). 


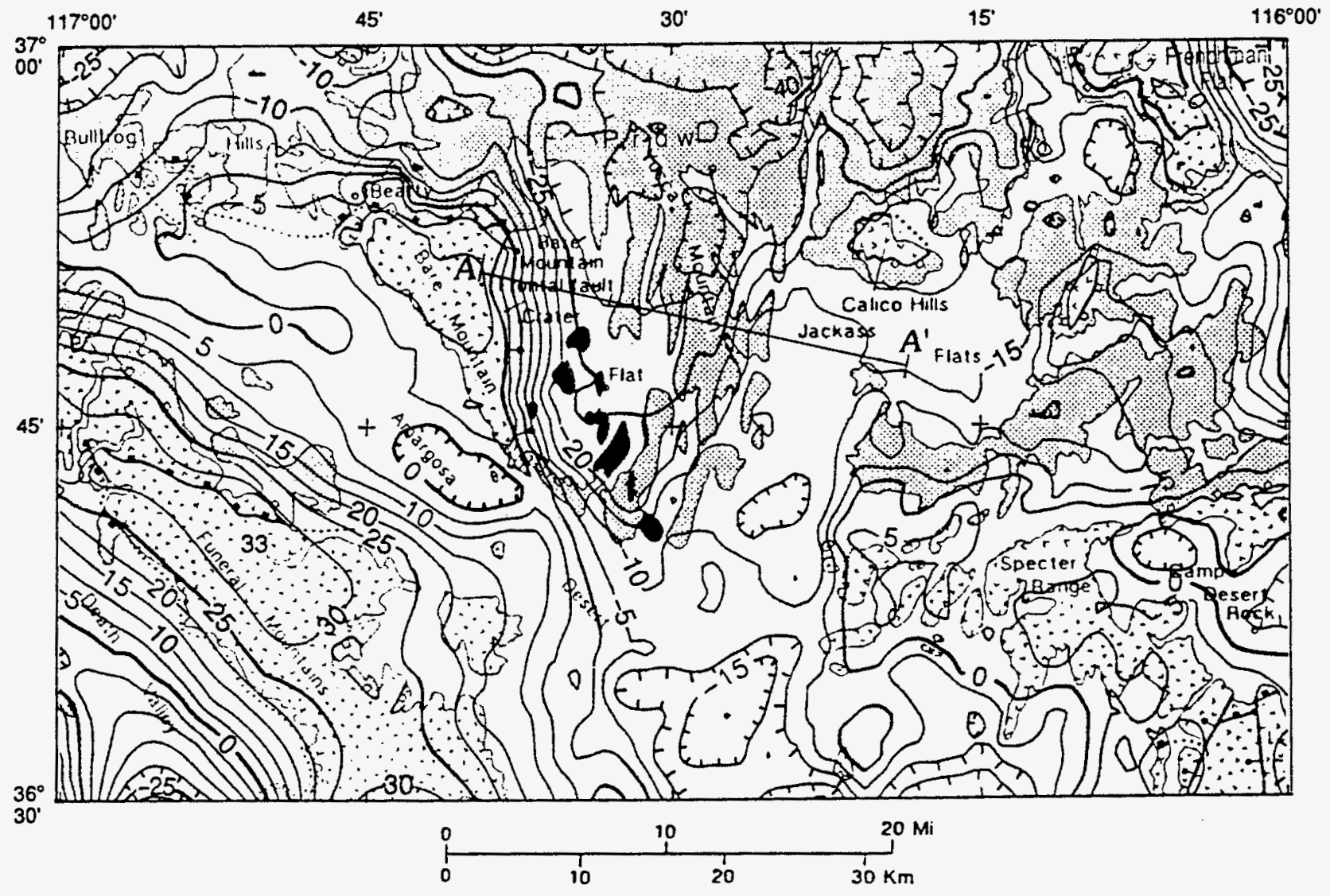

EXPLANATION

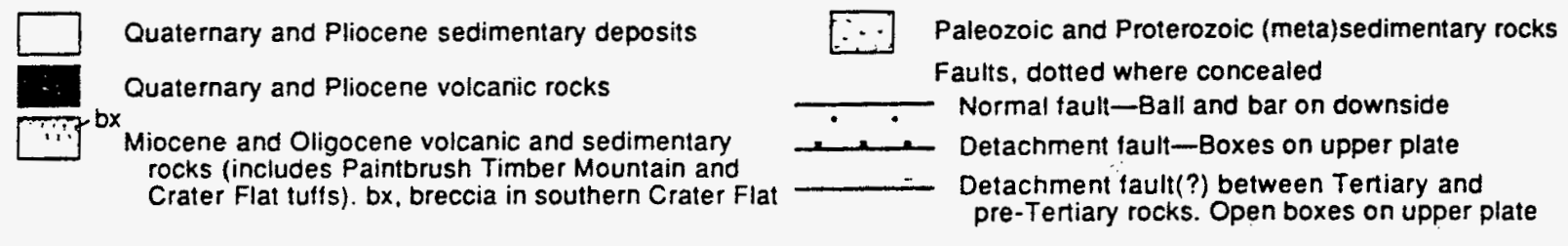

Figure 2.4. Isostatic gravity map of the Beatty $1 / 2^{\circ}$ by $1^{\circ}$ quadrangle, Nevada, showing the location of the gravity model along profile A-A', overprinted on a simplified geologic base. Gravity contour is $5 \mathrm{mGal}$, and the reduction density is 2.67 gm/ $\mathrm{cm}^{3}$. The gravity map is controlled by over 2000 gravity stations. Hachured contours indicate gravity lows. 

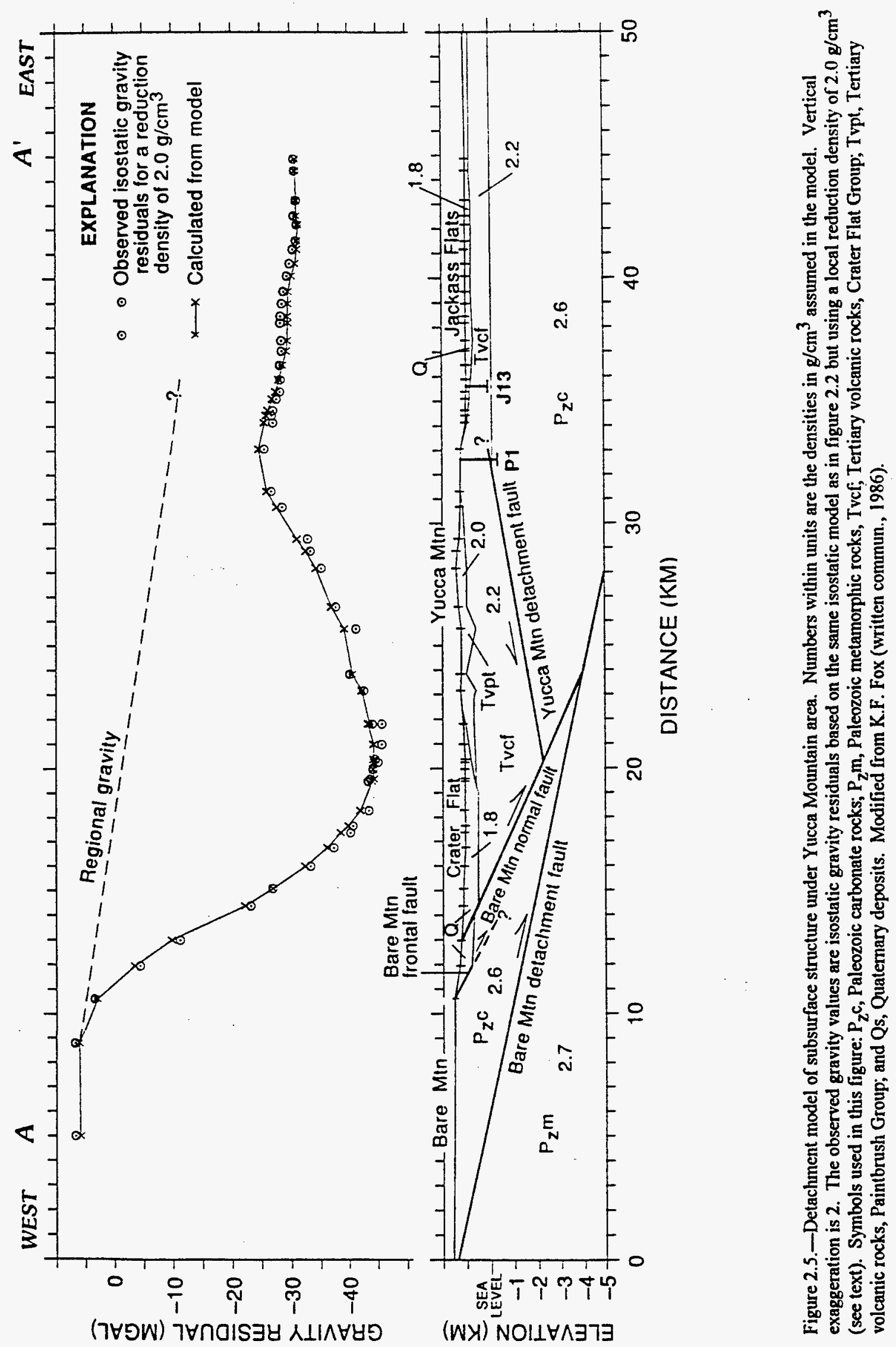


\section{FORTYMILE WASH}

Another current regional gravity study is that of Fortymile Wash, a linear feature that extends for about $65 \mathrm{~km}$, partly along the east side of Yucca Mountain (fig 2.4). Because Fortymile Wash was believed to be fault-controlled (Lipman and McKay, 1965), there was concern that if a fault extended to repository depths of about $400 \mathrm{~m}$, it might provide a highly permeable zone through which water-borne radionuclides might travel rapidly. For these reasons, electrical data were collected along four profiles (Hoover and others, 1982a) and subsequently, detailed gravity and ground magnetic data were collected along six profiles (Ponce and others, 1992) across Fortymile Wash (fig. 2.6). Profiles for two of the gravity traverses are shown (fig. 2.7 ), reduced for a density of $2.0 \mathrm{~g} / \mathrm{cm}^{3}$. This reduction density was determined using density profiling (Nettleton, 1976), an interpretive technique to determine the average density of small topographic features by selecting the density profile that exhibits the least correlation to topography. Combined results from all six profiles suggest that a density between 1.8 to 2.0 $\mathrm{g} / \mathrm{cm}^{3}$ produces the least correlation to topography and probably represents the average density of the near-surface layer of Fortymile Wash.

The largest gravity (and magnetic) anomaly in the vicinity of Fortymile Wash is the Paintbrush fault, on the west side of Fran Ridge (figs. 2.6 and 2.7). Because the gravity stations are closely spaced, they provide a very accurate location of the fault, which is about $300 \mathrm{~m}$ east of the location shown on the geologic map of Lipman and McKay (1965). A later detailed geologic map utilizing geophysical evidence shows the fault in the correct location (Scott and Bonk, 1984). The amplitude of the gravity anomaly associated with the Paintbrush fault is about $2 \mathrm{mGal}$. Using as a model the maximum effect of a vertical fault (Nettleton, 1976, p. 193-195), the anomaly implies an offset of about 180 to $240 \mathrm{~m}$.

Gravity data suggest that Fortymile Wash does not itself lie over a fault unless movement has occurred between rock types of similar density. In the vicinity of Fran Ridge, essentially coincident with gravity lines 2 and 3 (figs. 2.6 and 2.7), electrical data by Hoover and others (1982a) revealed four north-south zones of low resistivity, two on either side of Fortymile Wash, that were interpreted to be fault zones. Gravity anomalies along line 2 (fig 2.7) correlate well with faults inferred from electrical data, especially at the Paintbrush fault, and suggest that vertical offsets along faults, if present, on the east side of Fortymile Wash are small compared to the offset at the Paintbrush fault. In contrast, gravity anomalies along line 3 (fig 2.7) do not correlate very well to faults inferred from electrical data, especially on the east side of the wash. In addition, gravity anomalies along profiles south of line 3 and Busted Butte (fig. 2.6, lines 4, 5, and 6) are of lower amplitude than those near Fran Ridge and are probably not related to large vertical offsets. Because of their short wavelength, gravity anomalies south of Busted Butte, but near Fortymile Wash, could be related to variations in density within the underlying alluvium or volcanic rocks.

Because these gravity studies were intended to determine whether or not Fortymile Wash lies over a fault, detailed gravity data were not collected more than about $3.2 \mathrm{~km}$ beyond the edge of the wash. Thus, the southernmost detailed profiles did not cross major regional anomalous gravity features that probably indicate major faults on either side of Fortymile Wash. Healey and Miller (1971) also recognized these gravity features, and electrical data (Hoover and others, 


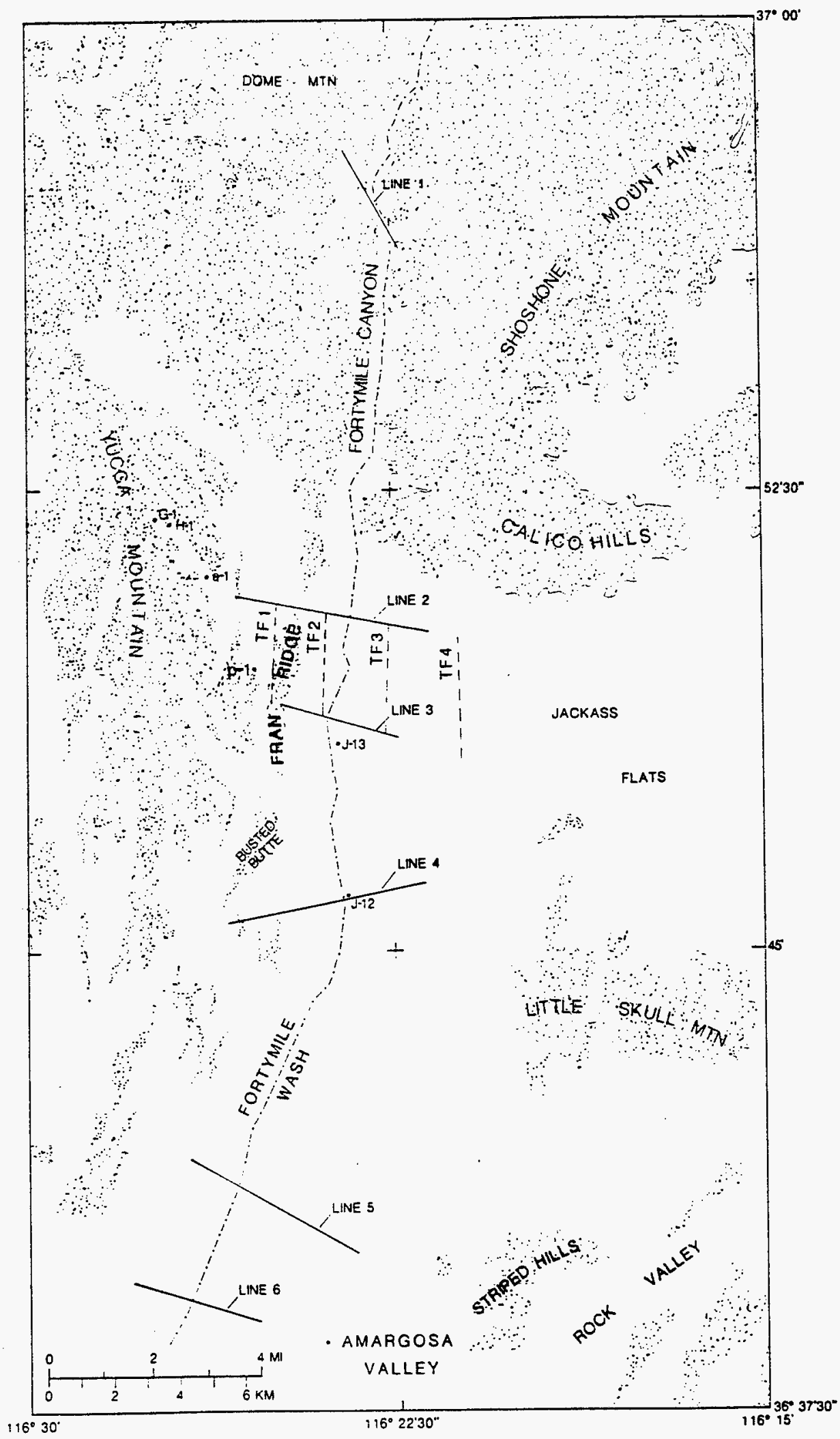

Figure 2.6.-Index map showing gravity profiles across Fortymile Wash and vicinity. TF1 to IF4 are faults inferred from electrical data. Stippled area denotes exposed rocis. Modified from Ponce and others (1988). 

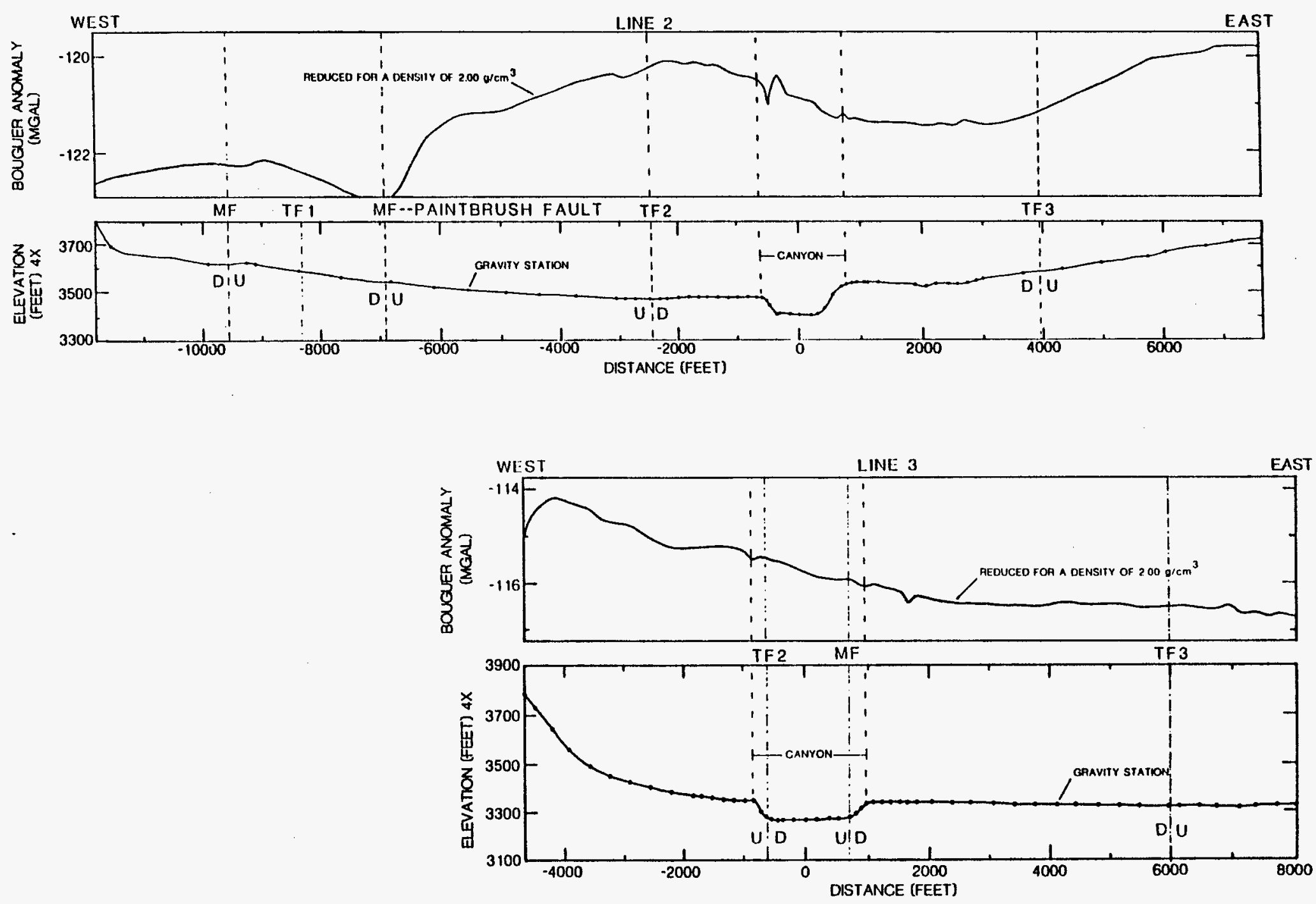

Figure 2.7.-Gravity and topographic profiles of line 2 and line 3 across Fortymile Wash, both near Fran Ridge. Refer to fig. 2.6 for locations. Symbols: MF, mapped geologic fault (Lipman and McKay, 1965); TF1 to TF3, inferred faults from electrical data (Hoover and others, 1982a) with electrode spacing of $500 \mathrm{~m}$, where TF1 is the Paintbrush fault; $U$, upthrown side of fault; $D$, downthrown side. Modified from Ponce and others (1992). 
1982a) and seismic refraction data (Mooney and Schapper, this volume) support the location of a major fault along the eastern edge of northern Amargosa Valley. In order to determine the exact nature of faulting, if present, in the immediate vicinity of Fortymile Wash, several profiles need to be extended, and additional detailed gravity, magnetic, and especially electrical data must be collected between the present profiles. These data would help determine whether or not faults inferred from geologic and electrical data in the immediate vicinity of Fortymile Wash (fig. 2.3; Ponce and others, 1992) and the major faults on either side of the wash in the northern part of the Amargosa Valley are related.

Detailed gravity data along line 2 , at about $-2,740 \mathrm{~m}$, show the presence of a gravity anomaly. This gravity anomaly is located near a mapped, although concealed, fault of Lipman and McKay (1965). This anomaly is continuous to the south for at least $2,000 \mathrm{~m}$ and probably represents a fault. Subsequently, a seismic refraction profile (H. D. Ackermann, written commun., 1984) indicated a low-velocity zone at depth, and electromagnetic soundings by Frischknecht and Raab (1984) indicated a major lateral discontinuity at this location. However, according to G. D. Bath (oral commun., 1984), the absence of an associated magnetic anomaly probably precludes the existence of large vertical offsets in the underlying magnetic units. Additional data, especially ground magnetic data, are required to determine the exact nature of this anomaly.

\section{OTHER INVESTIGATIONS}

Ponce and Oliver (1981) established a gravity calibration loop over Charleston Peak to test meter performance and check calibration factors of the meters, the first such calibration loop in Nevada. Based on repeated occupations of the loop they found the loop to be sufficiently stable for calibrating the meters to about 1 part in 10,000. This calibration loop is well suited for studies at the Nevada Test Site due to its proximity and because it encompasses the range of observed gravity values at the Nevada Test Site.

Subsequently, Zumberge and others (1988) established four absolute gravity stations in southern Nevada. Three of them are on the Nevada Test Site, at Mercury, at Test Cell C, and at Check Point 2. The fourth station is at the Kyle Canyon Ranger Station along the Charleston Peak calibration loop. The purpose of these measurements is to provide absolute gravity control for the calibration loop and to provide an absolute datum for high-precision gravity measurements over Yucca Mountain. Comparisons between absolute and relative gravity measurements between Mercury and Kyle Canyon Ranger Station indicate that the calibration factors are good to not quite 1 part in 10,000. The Kyle Canyon absolute-measurement site is apparently of poor quality which adversely affects the comparison. Preliminary work at the Mt. Hamilton calibration loop in California indicates that the calibration factors there are better than 0.1 part in 10,000 (R.N. Harris and C.W. Roberts, oral commun., 1987). To resolve this discrepancy between the Charleston Peak and Mt. Hamilton calibration loops, the Kyle Canyon site should be reoccupied or another absolute site on Mt. Charleston should be selected. 
A high-precision gravity loop was established across Yucca Mountain providing a rapid and inexpensive method of monitoring temporal changes in gravity (Harris and Ponce, 1988). The gravity loop has been tied to absolute gravity measurements (Zumberge and others, 1988), establishing a datum for monitoring absolute changes in gravity. Moreover, the high-precision gravity loop has been established along a first-order geodetic level line to study the relationship between possible variations in gravity and elevation. Fluctuations in the gravity field may result from vertical movements along the free-air gradient or variations in the subsurface density field. Determining the relationship between changes in gravity and elevation helps to discriminate between these two processes. Additional reoccupations of the high-precision gravity loop will be made as opportunity and necessity permit.

\section{LIMITATIONS OF EXISTING DATA}

Interpretation of gravity data does not produce a unique solution. This arises from the fact that a given gravity distribution can be produced or modeled by an infinite number of mass or density distributions. Thus, it is important that all available geologic and geophysical information be used as independent constraints to discriminate between possible solutions. Conversely, it is important that gravity data be collected along other geophysical traverses such as seismic, magnetic, and electric, so that the interpretations from these various methods can help constrain one another.

Because current investigations are being concentrated in the southwestern part of the Nevada Test Site and vicinity, detailed gravity data are needed to supplement the existing, in general, regional coverage (fig. 2.3). In areas of special interest, closely spaced gravity data are needed to help define concealed or unknown faults or structures. Repeatable high-precision gravity surveys are necessary to monitor temporal variations in the gravity field, which may be related to tectonism or water-table changes. Absolute gravity measurements are necessary to provide a datum for the relative gravity measurements and can be used to monitor broad-scale changes in the gravity field.

Physical property measurements are critical to the interpretation of gravity, as well as magnetic, data. Although there are numerous reports on density data, a considerable effort is needed to synthesize the data. Density data should be summarized by lithology and method used, and sufficient information on density variations within layers is needed so that a detailed density model can be formulated. In addition, borehole gravity-meter data should be collected to provide an independent measure of in situ density and information on surrounding structures. 


\section{REFERENCES CITED}

Ackermann, H.D., Mooney, W.D., Snyder, D.B., and Sutton, V.D., 1988, Preliminary interpretation of seismic-refraction and gravity studies west of Yucca Mountain, Nevada and California, in Carr, M.D., and Yount, J.C., eds., Investigations of the geological and geophysical characterization of a potential nuclear waste disposal site at Yucca Mountain, southern Nevada: U.S. Geological Survey Bulletin 1790, p. 23-34.

Brocher, T.M., Hart, P.E., and Carle, S.F., 1990, Feasibility study of the seismic reflection method in Amargosa Desert, Nye County, Nevada: U.S. Geological Survey Open-File Report 89-133, 150 p.

Carr, M.D., Waddell, S.J., Vick, G.S., Stock, J.M., Monsen, S.A., Harris, A.G., Cork, B.W., and Byers, F.M., 1986, Geology of drill hole UE-25p\#1: A test hole into pre-Tertiary rocks near Yucca Mountain, southern Nevada: U.S. Geological Survey Open-File Report 86-175, 87 p.

Evans, J.R., and Oliver, H.W., 1987, Comparison of Timber Mountain Caldera Complex, Nevada, with Yellowstone. Speculations on mechanism (Extended Abstract with 1 illustration), in Decker, R.W., ed., Hawaii Symposium on How Volcanoes Work, Hilo, Hawaii, January 19-25, 1987, Abstract Volume: University of Hawaii at Hilo, p. 67.

Frischknecht, F.C., and Raab, P.V., 1984, Time-domain electromagnetic soundings at the Nevada Test Site, Nevada: Geophysics, v. 49, no. 7, p. 981-992.

Harris, R.N., Ponce, D.A., Healey, D.L., and Oliver, H.W., 1989, Principal facts about 16,000 gravity stations in the Nevada Test Site and vicinity, Nevada: U.S. Geological Survey OpenFile Report 89-682-A, Principal Facts Documentation, 78 p.

Harris, R.N., Oliver, H.W., and Healey, D.L., 1986, Structural implications of an isostatic residual gravity map of the Nevada Test Site, Nevada (abs.): EOS (Transactions American Geophysical Union), v. 67, no. 44, p. 262.

Harris, R.N., and Ponce, D.A., 1988, High-precision gravity network to monitor temporal variations in gravity across Yucca Mountain, Nevada: U.S. Geological Survey Open-File Report 88-243, 19 p.

Healey, D.L., 1968, Application of gravity data to geologic problems at the Nevada Test Site, in Eckel, E.B., ed., Nevada Test Site: Geological Society of America Memoir 110, p. 147-156.

-...- 1970, Calculated in situ bulk densities from subsurface gravity observations and density logs, Nevada Test Site and Hot Creek Valley, Nye County, Nevada, in Geological Survey Research: U.S. Geological Survey Professional Paper 700 B, p. B52-B62.

-.-. 1983, Gravity investigations, in Geologic and geophysical investigations of Climax Stock intrusive, Nevada: U.S. Geological Survey Open-File Report 83-377, 76 p. 
Healey, D.L., Clutsom, F.G., and Glover, D.A., 1984, Borehole gravity meter surveys in drill holes USW G-3, UE-25p\#1, and UE-25c\#1, Yucca Mountain area, Nevada: U.S. Geological Survey Open-File Report 84-672, 16 p.

--- --.- 1986, Borehole gravity meter survey in drill hole USW G-4, Yucca Mountain area, Nye County, Nevada: U.S. Geological Survey Open-File Report 86-205, 18 p.

Healey, D.L., Harris, R.N., Ponce, D.A., Oliver, H.W., 1988, Complete Bouguer gravity map of the Nevada Test Site and vicinity: U.S. Geological Survey Open-File Report 87-506, scale $1: 100,000$.

Healey, D.L., and Miller, C.H., 1971, Gravity survey of the Amargosa Desert area of Nevada and California: U.S. Geological Survey Report USGS-474-136 (U.S. Geological Survey Technical Letter NTS-99), $30 \mathrm{p}$.

-... 1979, Interpretation of gravity data in the Timber Mountain area of the Nevada Test Site: U.S. Geological Survey Report USGS-474-308 (U.S. Geological Survey Technical Letter NTS-105), $47 \mathrm{p}$.

Healey, D.L., Snyder, D.B., Wahl, R.R., and Currey, F.E., 1981, Bouguer gravity map of Nevada, Caliente sheet: Nevada Bureau of Mines and Geology Map 70, scale 1:250,000.

Healey, D.L., Wahl, R.R., and Currey, F.E., 1980, Bouguer gravity map of Nevada, Goldfield and Mariposa sheets: Nevada Bureau of Mines and Geology Map 68, scale 1:250,000.

Healey, D.L., Wahl, R.R., and Oliver, H.W., 1980, Bouguer gravity map of Nevada, Death Valley sheet: Nevada Bureau of Mines and Geology Map 69, scale 1:250,000.

Heinrichs, E.N., 1963, Geology of the Ammonia Tanks quadrangle, Nye County, Nevada: U.S. Geological Survey Technical Letter NTS-59.

Hildenbrand, T.G., Rogers, A.M., Oliver, H.W., Harmsen, S.C., Nakata, J.K., Aitken, D.S., Harris, R.N., and Carr, M.D., 1988, Regional geologic and geophysical maps of Southern Great Basin, in Carr, M.D., and Yount, J.C., eds., Geologic and hydrologic investigations of a potential nuclear waste disposal site at Yucca Mountain, southern Nevada: U.S. Geological Survey Bulletin 1790, p. 3-21.

Hoffman, L.R., and Mooney, W.D., 1983, A seismic study of Yucca Mountain and vicinity, southern Nevada; data report and preliminary results: U.S. Geological Survey Open-File Report 83-588, 50 p.

Hoover, D.B., Chornack, M.P., and Broker, M.M., 1982a, E-field ratio telluric traverses near Fortymile Wash: U.S. Geological Survey Open-File Report 82-1042, 14 p.

Hoover, D.B., Hanna, W.F., Anderson, L.A., Flanigan, V.J., and Pankratz, L.W., 1982b, Geophysical studies of the Syncline Ridge area, Nevada Test Site, Nye County, Nevada: U.S. Geological Survey Open-File Report 82-145, 55 p. 
Hoover, D.L., and Morrison, J.N., 1980, Geology of the Syncline Ridge area related to nuclear waste disposal, Nevada Test Site, Nye County, Nevada: U.S. Geological Survey Open-File Report 80-942, 69 p.

Izett, G.A., 1960, "Granite" exploration hole, Area 15, Nevada Test Site, Nye County, Nevada-Interim report, Part C, physical properties: U.S. Geological Survey Open-File Report TEM$836-\mathrm{c}, 36 \mathrm{p}$.

Jachens, R.C., and Griscom, Andrew, 1985, An isostatic residual gravity map of California--A residual map for interpretation of anomalies from intracrustal sources, in Hinze, W.J., ed., The utility of regional gravity and magnetic anomaly maps: Society of Exploration Geophysicists, Tulsa, Oklahoma, p. 347-360.

Jachens, R.C., and Roberts, C.W., 1985, Temporal and areal gravity investigations at Long Valley caldera, California: Journal of Geophysical Research, v. 90, p. 11,210-11,218.

Jansma, P.E., Snyder, D.B., and Ponce, D.A., 1982, Principal facts of gravity stations with gravity and magnetic profiles from the southwest Nevada Test Site, Nye County, Nevada, as of January, 1982: U.S. Geological Survey Open-File Report 82-1041, 43 p.

Johnson, R.B., and Ege, I.R., 1964, Geology of the Pluto Site, Area 401, Nevada Test Site, Nye County, Nevada: U.S. Geological Survey Trace Elements Investigations Report TEI-841, $127 \mathrm{p}$.

Kane, M.F., Healey, D.L., Peterson, D.L., Kaufmann, H.E., and Reidy, D., 1979, Bouguer gravity map of Nevada, Las Vegas sheet: Nevada Bureau of Mines and Geology Map 61, scale $1: 250,000$.

Kane, M.F., Webring, M.W., and Bhattacharyya, B.K., 1981, A preliminary analysis of gravity and aeromagnetic surveys of the Timber Mountain Area, southern Nevada: U.S. Geological Survey Open-File Report 81-189, 40 p.

Keller, G.V., 1959, Porosity, density, and fluid permeability of the Oak Spring Formation, in Diment, W.H., and others, Properties of the Oak Spring Formation in Area 12 at the Nevada Test Site: U.S. Geological Survey Trace Elements Investigations Report TEI-672.

Lipman, P.W., and McKay, E.J., 1965, Geological map of the Topopah Spring SW quadrangle, Nye County, Nevada: U.S. Geological Survey Geologic Quadrangle Map GQ-439, scale $1: 24,000$.

Maldonado, Florian, Muller, D.C., and Morrison, J.N., 1979, Preliminary geologic and geophysical data of the UE25a-3 exploratory drill hole, Nevada Test Site, Nye County, Nevada: U.S. Geological Survey Open-File Report USGS-1543-6, 43 p.

Nettleton, L.L., 1976, Gravity and magnetics in oil prospecting: McGraw-Hill Company, New York, $464 \mathrm{p}$. 
Oliver, H.W., and Carle, S.F., 1988, Compilation of gravity anomalies associated with calderas in North America [abs.]: Geological Society of America, 1988 Centennial Celebration, Abs. with Programs, p. A400.

Oliver, H.W., and Robbins, S.L., 1982, Bouguer gravity map of California, Mariposa sheet: California Division of Mines and Geology, scale 1:250,000.

Oliver, H.W., Saltus, R.W., Mabey, D.R., and Hildenbrand, T.G., 1982, Comparison of Bouguer anomaly and isostatic residual maps of the southwestern Cordillera [abs.]: Society of Exploration Geophysicists, Fifty-second Annual Meeting, Dallas, Texas, October 17-21, 1981, Technical Program Abstracts, p. 306-308.

Ponce, D.A., 1981, Preliminary gravity investigations of the Wahmonie site, Nevada Test Site, Nye County, Nevada: U.S. Geological Survey Open-File Report 81-522, 64 p.

... -..- 1984, Gravity and magnetic evidence of a granitic intrusion near Wahmonie site, Nevada Test Site, Nevada: Journal of Geophysical Research, v. 89, no. B11, p. 9,401-9,413.

Ponce, D.A., and Hanna, W.F., 1982, Preliminary appraisal of gravity and magnetic data at Syncline Ridge, western Yucca Flat, Nevada Test Site, Nye County, Nevada: U.S. Geological Survey Open-File Report 82-931, 19 p.

Ponce, D.A., Harris, R.N. and Oliver, H.W., 1988, Isostatic gravity map of the Nevada Test Site and vicinity, Nevada: U.S. Geological Survey Open-File Report 88-664, scale 1:100,000, 1 sheet.

Ponce, D.A., Kohrn, S.B., and Waddell, Sandra, 1992, Gravity and magnetic data of Fortymile Wash, Nevada Test Site, Nevada: U.S. Geological Survey Open-File Report 92-343, 33 p.

Ponce, D.A., and Oliver, H.W., 1981, Charleston Peak gravity calibration loop, Nevada: U.S. Geological Survey Open-File Report 81-985, 20 p.

Robbins, S.L., 1980, Bibliography with abridged abstracts of subsurface gravimetry (especially borehole) and corresponding in situ rock density determinations: U.S. Geological Survey Open-File Report 80-710, $47 \mathrm{p}$.

Robbins, S.L., Schmoker, J.W., and Hester, T.C., 1982, Principal facts and density estimates for borehole gravity stations in exploratory wells Ue4ah, Uelh, Uelq, Ue2co, and USW-Hl at the Nevada Test Site, Nye County, Nevada: U.S. Geological Survey Open-File Report 82$277,33 \mathrm{p}$.

Saltus, R.W., 1988, Gravity data for the State of Nevada on magnetic tape: U.S. Geological Survey Open-File Report 88-433, 20 p.

Sawyer, David A., Fleck, R.J., Lanphere, M.A., Warren, R.G., Broxton, D.E., Hudson, Mark R., 1994, Episodic caldera volcanism in the Miocene southwestern Nevada volcanic 
field: Revised stratigraphic framework, ${ }^{40} \mathrm{Ar} /{ }^{39} \mathrm{Ar}$ geochronology, and implications for magmatism and extension: Geological Society of America Bulletin, v. 106, p. 1304-1318.

Scott, R.B., and Bonk, Jerry, 1984, Preliminary geologic map of Yucca Mountain, Nye County, Nevada, with geologic sections: U.S. Geological Survey Open-File Report 84-494, scale $1: 12,000$.

Simpson, R.W., Jachens, R.C., and Blakely, R.J., 1983, Airyroot: a FORTRAN program for calculating the gravitational attraction of an Airy isostatic root out to $166.7 \mathrm{~km}$ : U.S. Geological Survey Open-File Report 83-883, 66 p.

-..- 1986, A new isostatic residual gravity map of the conterminous United States with a discussion on the significance of isostatic residual gravity anomalies: Journal of Geophysical Research, v. 91, no. B8, p. 8,348-8,372.

Snyder, D.B., and Carr, W.J., 1982, Preliminary results of gravity investigations at Yucca Mountain and vicinity, southern Nye County, Nevada: U.S. Geological Survey Open-File Report 82-701, 36 p.

-..-.-. 1984, Interpretation of gravity data in a complex volcano-tectonic setting, southwestern Nevada: Journal of Geophysical Research, v. 89, no. B12, p. 10, 193-10,206.

Snyder, D.B., and Oliver, H.W., 1981, Preliminary results of gravity investigations of the Calico Hills, Nevada Test Site, Nye County, Nevada: U.S. Geological Survey Open-File Report 81$101,42 \mathrm{p}$.

Snyder, D.B., Roberts, C.W., Saltus, R.W., and Sikora, R.F., 1982, Magnetic tape containing the principal facts of 64,026 gravity stations in the State of California: U.S. Geological Survey Report PB 82-168729, 34 p. [Available from National Technical Information Service, U.S. Department of Commerce, Springfield, VA 22161, NTIS PB-82168287.]

U.S. Department of Energy, 1986, Environmental assessment, Yucca Mountain Site, Nevada Research and Development Area, Nevada: U.S. Department of Energy, Office of Civilian Waste Management Report DOE/RW-0073.

U.S. Geological Survey, 1984, A summary of geologic studies through January 1, 1983, of a potential high-level radioactive waste repository site at Yucca Mountain, southern Nye county, Nevada: U.S. Geological Survey Open-File Report 84-792, 103 p.

U.S. Nuclear Regulatory Commission, 1983, Disposal of high-level radioactive wastes in geologic repositories (10 CFR Part 60): U.S. Federal Register, v. 48, no. 120, Tuesday, June 21,1983 , p. $28194-28229$.

Zumberge, M.A., Harris, R.N., Oliver, H.W., Sasagawa, G.S., and Ponce, D.A., 1988, Preliminary results of absolute and high-precision gravity measurements at the Nevada Test Site and vicinity, Nevada: U.S. Geological Survey Open-File Report 88-242, 29 p. 
$\therefore$ 


\title{
MAJOR RESULTS OF GEOPHYSICAL INVESTIGATIONS AT YUCCA MOUNTAIN AND VICINITY, SOUTHERN NEVADA
}

\section{CHAPTER 3: MAGNETIC INVESTIGATIONS}

\author{
By H.W. Oliver, D.A. Ponce, and H.R. Blank
}

\section{INTRODUCTION}

Magnetic methods are useful for locating and delimiting plutons, calderas, and faults; for determining depth to basement; and for tracing magnetic horizons concealed below the surface. Because most rock units contain a small percentage of magnetite or other magnetic minerals, they can be detected by a magnetometer provided their magnetic susceptibility and thickness are sufficient to produce observable anomalies. Thus, it is important to establish a relation between magnetic anomalies and the causative rock units and their magnetic properties. Bath (1968) began these studies at the Nevada Test Site using rock samples collected from surface outcrops and drill holes and used these data to determine subsurface geologic structure. Bath showed that remanent magnetization was responsible for almost all of the prominent aeromagnetic anomalies associated with Tertiary volcanic rocks at the Nevada Test Site and vicinity. Of the more than 50 volcanic units that were investigated, only 13 had the remanent intensity and thickness required to produce aeromagnetic anomalies. Of these 13 , seven are normally magnetized and six are reversely magnetized.

\section{MAGNETIC FEATURES OF SOUTHERN NEVADA AND PART OF EASTERN CALIFORNIA}

Some 39 aeromagnetic surveys in southern Nevada and 11 surveys in adjacent parts of California have been conducted within a radius of $140 \mathrm{~km}$ from the potential site area being evaluated for storage of radioactive waste at Yucca Mountain. These surveys have been compiled here (fig. 3.1). All of the 50 surveys have been downward-continued or, in a few cases, upward-continued to a common level of $300 \mathrm{~m}$ above terrain. The details of the locations, spacing, and flight elevations of the 50 sources are too numerous to show here but are contained in a separate report by Sikora and others (1993). Limitations in existing data are primarily a function of flight line spacing and draping.(fig. 3.2). For example, there are now draped surveys with both 0.4 and $0.8 \mathrm{~km}$ spacing available within about $30 \mathrm{~km}$ of the potential site area (fig. 1.1), but control is weak in the Death Valley region beginning about $30 \mathrm{~km}$ west of the site area. A more detailed compilation at $120 \mathrm{~m}$ above terrain in the immediate vicinity of Yucca Mountain has also been compiled (fig. 3.3).

In southern Nevada, the regional aeromagnetic map (fig. 3.1) shows broad magnetic highs (1) adjacent to the site area, (2) over the Spring Mountains about $40 \mathrm{~km}$ west of Las Vegas, and (3) near the Las Vegas and Mormon Mountains northeast of Las Vegas. In adjacent parts of California, there is a northwest-trending magnetic lineament over the Greenwater Range as 

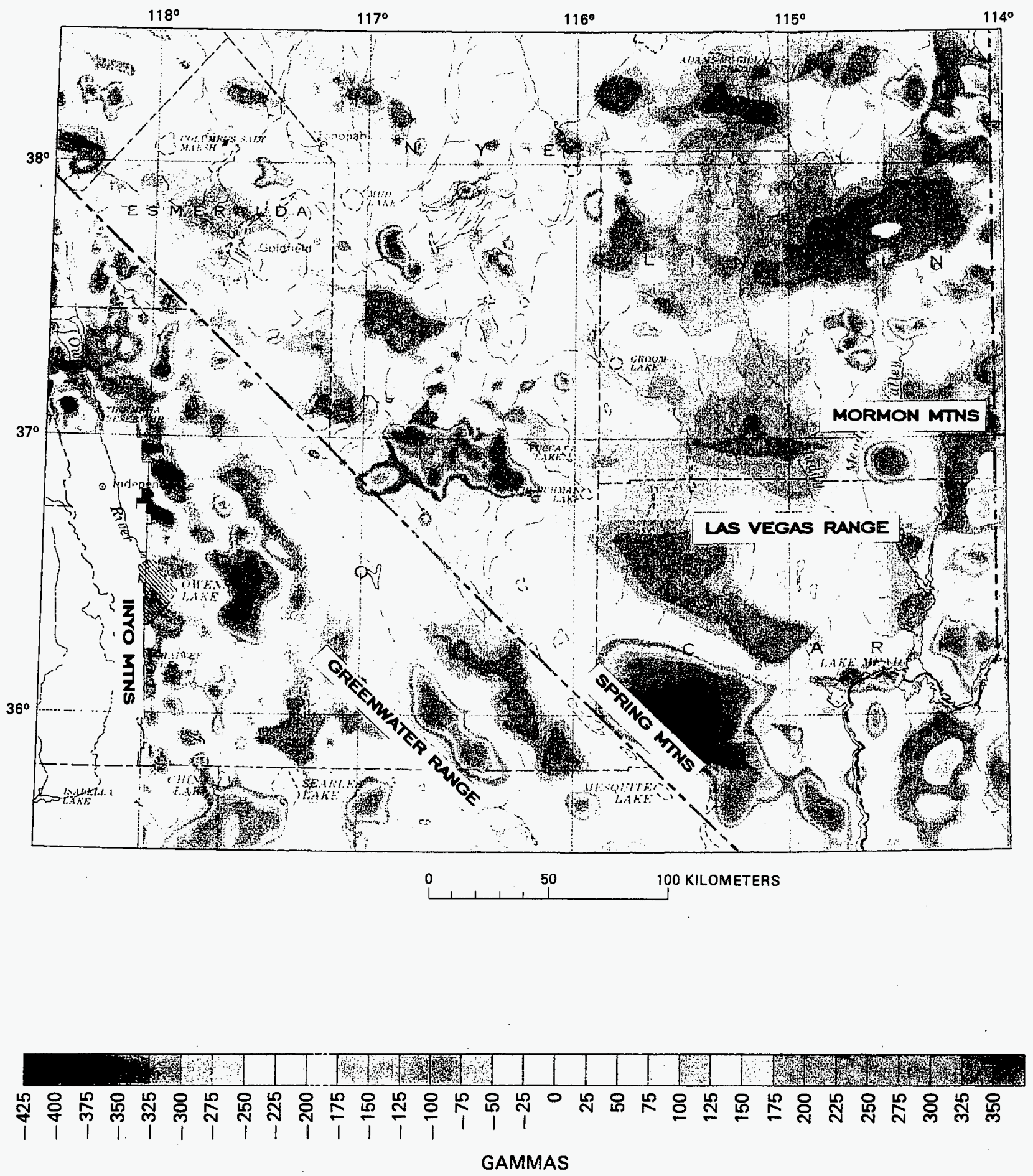

Figure 3.1-Residual total magnetic anomaly map of the southern Great Basin at $300 \mathrm{~m}$ above terrain. Modified from Hildenbrand and others (1988, fig. 2.12). Contour interval $25 \mathrm{nT}$. 
well as a series of magnetic highs over the Inyo Mountains. A north-trending zone in the eastern part of Nevada with magnetic values of -100 to $0 \mathrm{nT}$ (fig. 3.1) is characterized by a general lack of short-wavelength anomalies and is known as the "quiet zone".

The northwest-trending magnetic high near the site area has been enlarged about seven times to a scale of $1: 357,000$, recompiled, and continued downward to a level of $120 \mathrm{~m}$ above terrain (fig. 3.3). This format shows that the regional magnetic high is made up of a series of separated highs from southeast to northwest over Wahmonie, Calico Hills, the northern third of Yucca Mountain, and the Prospector Pass caldera. At Wahmonie, the magnetic high occurs over Miocene granitic intrusive rocks (Ponce, 1984). At Calico Hills, the center of the high is caused by local alteration of magnetite (known from drilling) within the Eleana Formation. There is also a broader component of the anomaly, and a depth analysis of that component suggests that the top of that source is about $3 \mathrm{~km}$ below the surface and that it has a magnetic susceptibility comparable to the granitic rocks exposed at Wahmonie.

Farther west, the magnetic high with values of 100 to $250 \mathrm{nT}$ extends across the northern third of Yucca Mountain. Depth analysis at the eastern edge of Yucca Mountain indicates that the contact between these magnetic basement rocks and the nonmagnetic basement rocks to the south, known from drilling to be dolomite, is at a depth of about $2.2 \mathrm{~km}$. The deepest well in the northern third of Yucca Mountain (USW G-2) reached depths of about $1.8 \mathrm{~km}$ and bottomed in $14 \mathrm{Ma}$ tuff, and thus it may have come within about $0.4 \mathrm{~km}$ of basement. West of Yucca Mountain, the magnetic high turns north for about $5 \mathrm{~km}$ before returning to its westerly trend and finally ends inside the Prospector Pass caldera, a distance of about $50 \mathrm{~km}$ west of Wahmonie. The most likely candidates for these east-west anomalies are the granitic rocks (exposed at Wahmonie) or some older granite with some intervals enhanced by baked argillite of the Eleana Formation. This finding has possible implications on structural and mineral assessment models of Yucca Mountain.

Other major regional magnetic anomalies in the vicinity of the potential site occur over the Spring Mountains about $30 \mathrm{~km}$ west of Las Vegas and the Mormon Mountains about $100 \mathrm{~km}$ northeast of Las Vegas (fig. 1.2). Integrated qualitative/quantitative interpretation of the total magnetic and derivative maps suggests the following relations:

1) The northern Spring Mountains, the Las Vegas Range and the Mormon Mountains are underlain by three broad swells on the surface of the Precambrian crystalline basement. These three swells and their associated aeromagnetic anomalies (see fig. 3.1) are aligned to the northeast, roughly collinear with the "iron axis" of southwestern Utah, an alignment of 2-Ma, iron-rich monzonite intrusions.

2) The Spring Mountains swell, at the southwest end of the triad and the source of the largest (most intense and broadest) aeromagnetic anomaly, contains at its core near its crest (depth 4 to $5 \mathrm{~km}$ ) an extremely magnetic body, elongated to the north, of somewhat lower density than that of the rocks comprising the bulk of the uplift. The northern and western margins of this body, if projected to the surface, closely follow the surface trace of the Keystone thrust. Thus, the anomalous body may be an iron-rich Tertiary (or at least postKeystone) intrusion whose emplacement produced the basement swell. 


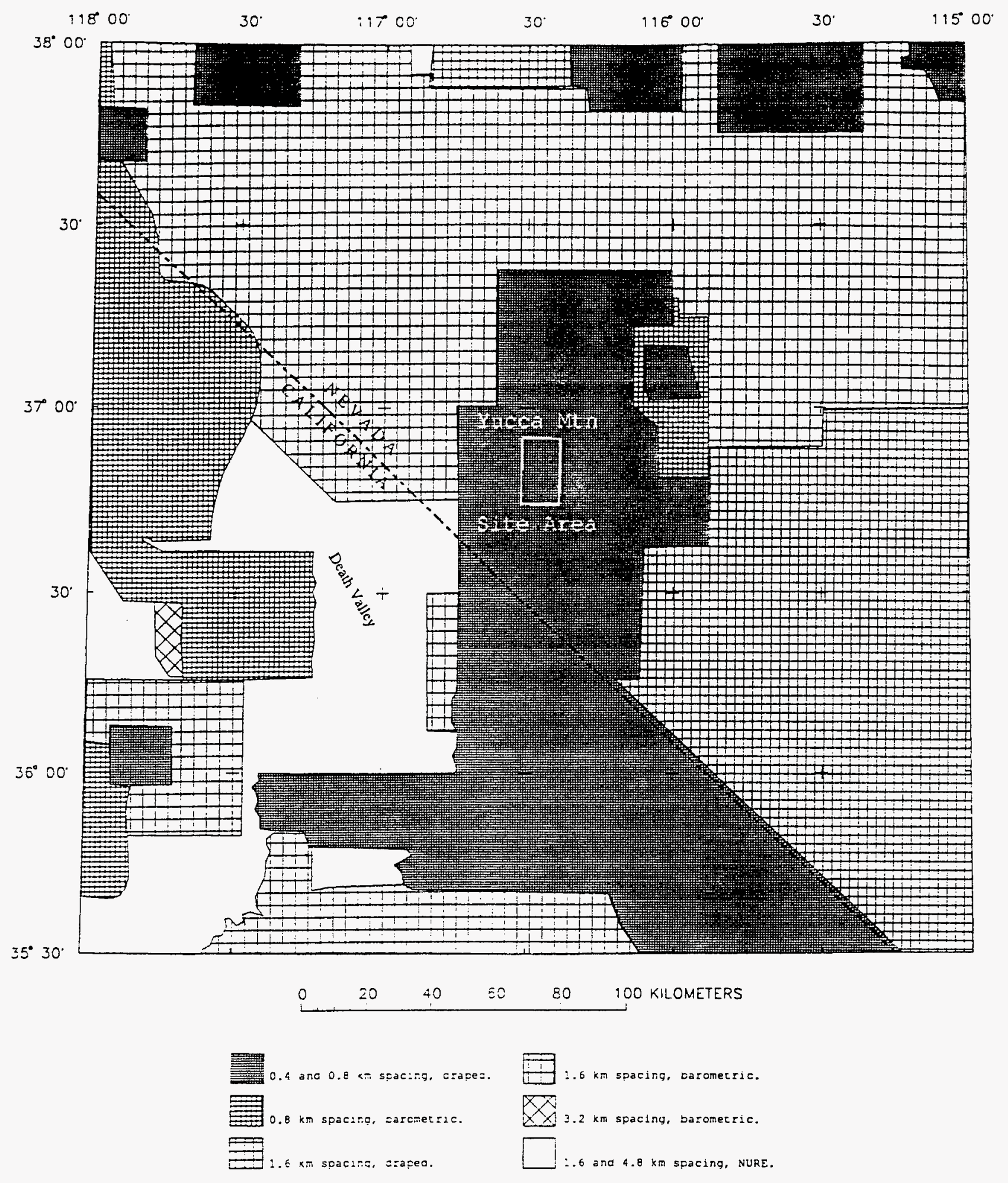

Figure 3.2-Aeromagnetic index map of the Regional Study Area showing flight line spacing of available data. These data consist of 39 separate surveys in Nevada and 11 in Cailfornia. Symbols: NURE, National Uranium Resource Evaluation program.

Modified from Oliver and others (1990). 


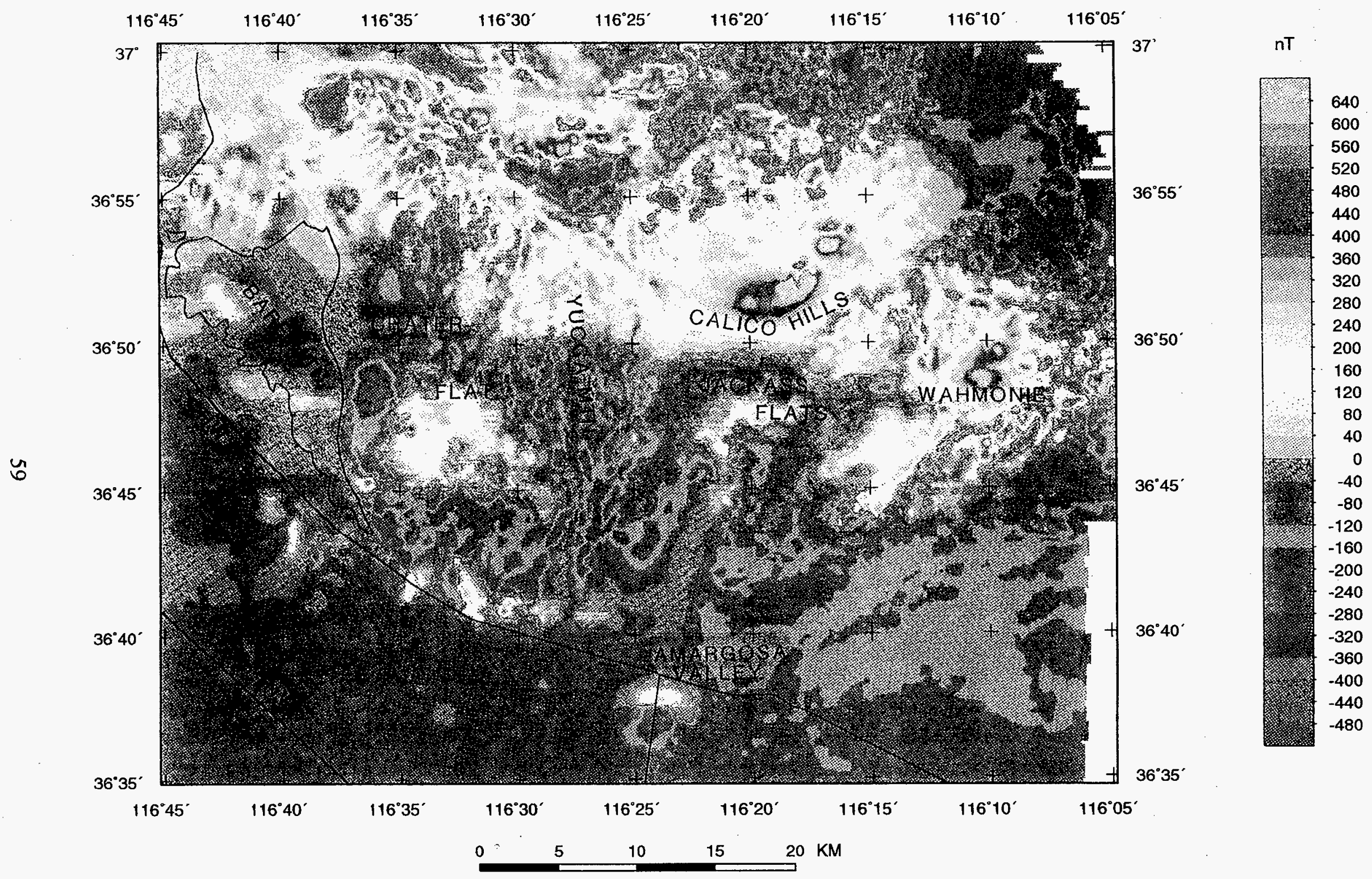

Figure 3.3-Total intensity aeromagnetic map of Yucca Mountain and vicinity at $120 \mathrm{~m}$ above terrain. Contour interval $25 \mathrm{nT}$. Flight line spacing about $0.4 \mathrm{~km}$. Modified from McCafferty (pers. commun.). 
3) The Mormon Mountains swell can be modeled as a symmetric dome of strongly magnetic basement rocks superimposed on a much broader basement uplift. The basement dome also involves Paleozoic cover rocks and the Miocene Mormon detachment fault, and it is the locus of Tertiary hydrothermal mineral systems. These relations suggest that the Mormon Mountains are also underlain by a Tertiary intrusive body.

Additional regional aspects of magnetic and gravity investigations have been described in the work of Blakely and others (1994). In California, the elongate magnetic high over the Greenwater Range overlies Precambrian to Tertiary rocks and extends to the northwest within remarkably continuous boundaries across Death Valley to Telescope Peak in the Panamint Range. Although recent geologic mapping indicates that this area has been grossly extended, depth analysis of these data by Blakely and others (1994) and the straight extension of the anomaly across currently active faulting suggest that the Greenwater Range has behaved as a coherent block at midcrustal depths.

The quiet magnetic zone in eastern Nevada described above has been studied by Blakely (1988). He concluded that the zone cannot be explained by a simple rise of the Curie temperature isotherm to shallower depth but rather by a lack of volcanic activity since $17 \mathrm{Ma}$ and the preponderance of S-type, ilmenite-bearing granites.

\section{VOLCANIC HAZARD STUDIES NEAR LATHROP WELLS AND IN CRATER FLAT}

Volcanic hazard studies are being carried out to evaluate the probability of future volcanism and to predict the effect of such volcanism on a potential repository at Yucca Mountain. These studies are of primary importance for site characterization efforts at the Nevada Test Site because geologic mapping has identified, at the potential high-level nuclear waste site, two of the three structures most often associated with basaltic volcanism, specifically Basin-and-Range faults, and ring fractures of inactive calderas (Crowe and others, 1983; Crowe and others, 1992). Based on studies of the timing and volume of known volcanic centers in the southern Great Basin, Crowe calculated an annual probability of basaltic volcanism of between $4.7 \times 10^{-8}$ and $3.3 \times 10^{-10}$. They felt that the actual probability is likely much less, based on an observed decrease in erupted volume over the past $4 \mathrm{~m}$.y. If other volcanic centers were discovered and included in the calculations, the probability estimates could increase significantly (B. Crowe, personal commun., 1993) but remain similarly small.

Aeromagnetic surveys in the Lathrop Wells and Crater Flat areas (fig. 3.3) revealed several anomalies similar to those of subaerial basaltic volcanic centers, but those were not associated with exposed basaltic rocks (figs. 3.4 and 3.5). These anomalies may indicate shallow intrusions or buried volcanic centers (Kane and Bracken, 1983).

Reversed magnetic lows also occur over the exposed volcanic centers named Black Cone and Red Cone in Crater Flat (fig. 3.4). A similar, but normally polarized, anomaly (marked "A" in the lower left corner of that figure, fig. 3.4) occurs over a flat desert surface and suggests the 
presence of a shallow, buried cone similar to the exposed cones but of an age when the earth magnetic field was normally polarized.

In the Lathrop Wells area, there are five magnetic doublets located over flat desert terrain that were discovered from the air (fig. 3.5). The largest of these, anomaly B, is reversely polarized and has been checked by both ground magnetic and gravity measurements and modeled by Langenheim and others (1993). Their results showed that the top of the causative body may be buried less than $250 \mathrm{~m}$ below the surface and probably less than $150 \mathrm{~m}$. The west edge of the body was drilled in 1991 in the oil-and-gas wildcat Felderhoff Federal 25-1 well (Carr and others, 1995), and basalt was penetrated at $104 \mathrm{~m}$ (Harris and others, 1992). Similarly, drilling much earlier near Anomaly D (fig. 3.5) encountered basalt cobbles at $183 \mathrm{~m}$ (Walker and Eakin, 1963). If all five of the dipolar anomalies (A-E, fig. 3.5) are caused by basaltic volcanic centers, this information could make an important contribution to estimates of the probability of future volcanism in the region.

\section{TRACING CONCEALED FAULTS IN YUCCA MOUNTAIN}

Because the fundamental structure of Yucca Mountain is a series of north-striking blocks each of which has been tilted down to the east along a series of faults, the detection of these faults, particularly where concealed by alluvium, is a vital part of the geologic-geophysical study. The easiest way to study these potential concealed structures is with aeromagnetic data supplemented with ground magnetic, gravity, and/or seismic refraction or reflection data as needed or affordable. Kane and Bracken (1983) were the first to call attention to the potential importance of fault-associated aeromagnetic anomalies but were soon followed by Bath and Jahren (1984), who summarized the magnetic properties and thicknesses of major near-surface ash flows in the potential repository area based on logs in drill holes USW G-1, G-2, and G-3. They also developed an understanding of expected aeromagnetic signatures associated with north-striking faults by computing the magnetic effect of offsetting these ash flows by vertical distances of $100,250,400$, and $700 \mathrm{~m}$, and at infinite distance (fig. 3.6). In all cases, the expected signal is a low to the west accompanied by a rise to the east of the fault of about double the magnitude of the western low. For example, a vertical fault displacement of $250 \mathrm{~m}$ down to the west should produce a magnetic low of about $20 \mathrm{nT}$ west of the fault and an approximate $40 \mathrm{nT}$ high to the east at an elevation of $152 \mathrm{~m}$ above ground.

This magnetic model has been tested with aeromagnetic data which show that the Topopah Spring Tuff of the Paintbrush Group (Sawyer and others, 1994) produces the main anomalies in the Yucca Mountain area. A vertical displacement of $70 \mathrm{~m}$ is required to produce a significant aeromagnetic anomaly (Bath and Jahren, 1984). For faults with smaller displacements, recent ground magnetic measurements have been successful in tracing concealed faults in Fortymile Wash (Ponce, and others, 1992), in Midway Valley (Ponce and others, 1993; Ponce, 1993), and in Yucca Wash (Langenheim, Ponce, and others, 1993). The profiles in Midway Valley are shown on the index map (fig. 3.7) as are lines FM-2 and -3 in Fortymile Wash and the several Yucca Wash profiles. The Solitario Canyon fault produces a magnetic signature similar to Bath's model (fig. 3.6) with a magnetic low to the west of about $-150 \mathrm{nT}$ and a high to the east 


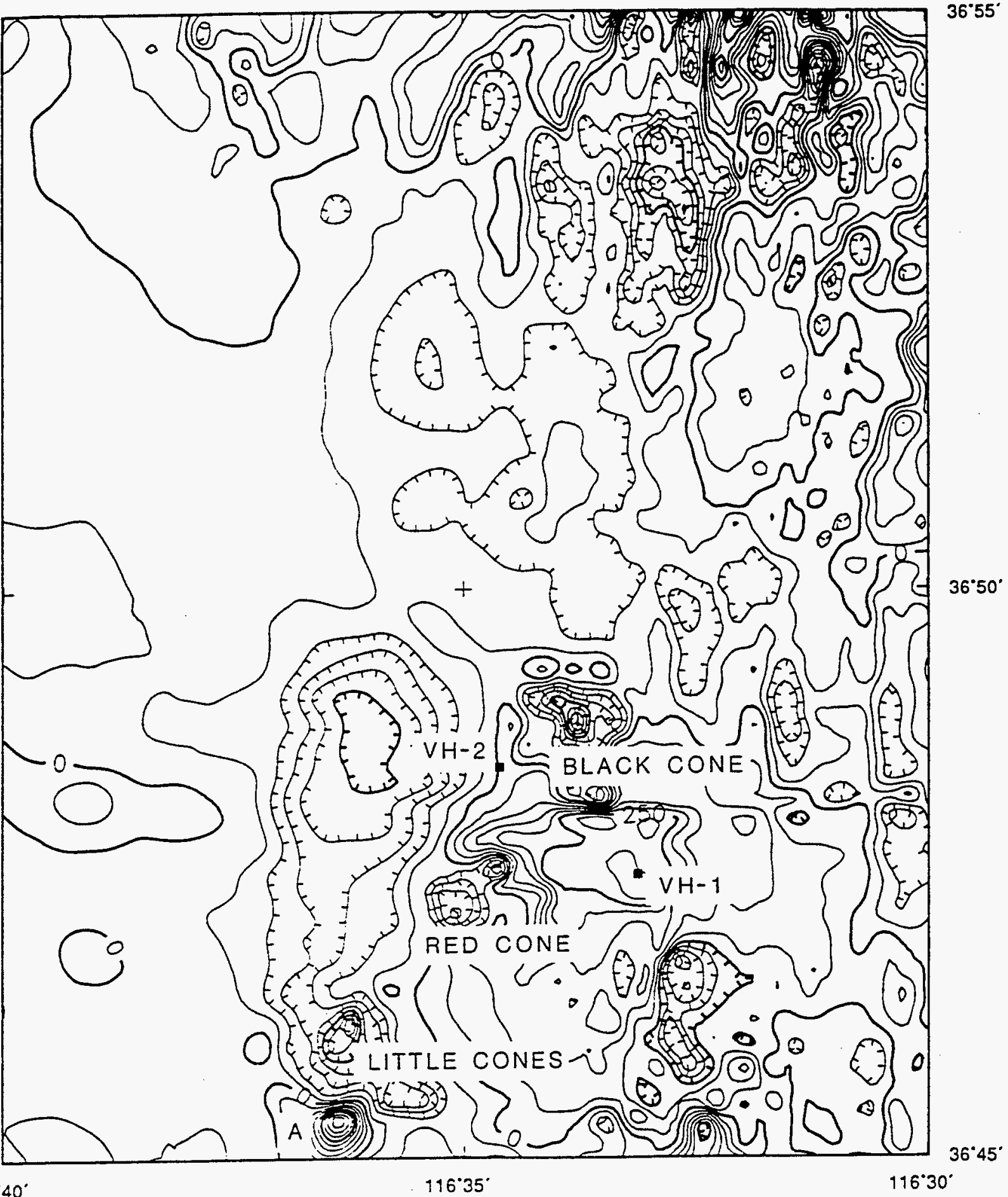

$36^{\circ} 45^{\circ}$

$116^{\circ} 40^{\circ}$

$5 \mathrm{KM}$

Figure 3.4-Aeromagnetic map of the Crater Flat area comparing the aeromagnetic signature over subaerial cinder cones (anomalies at Black Cone and at Red Cone) with an anomaly not associated with exposed lava (anomaly A). Also marked is the Little Cone anomaly which extends down the western and southwestern side of Crater Flat. 


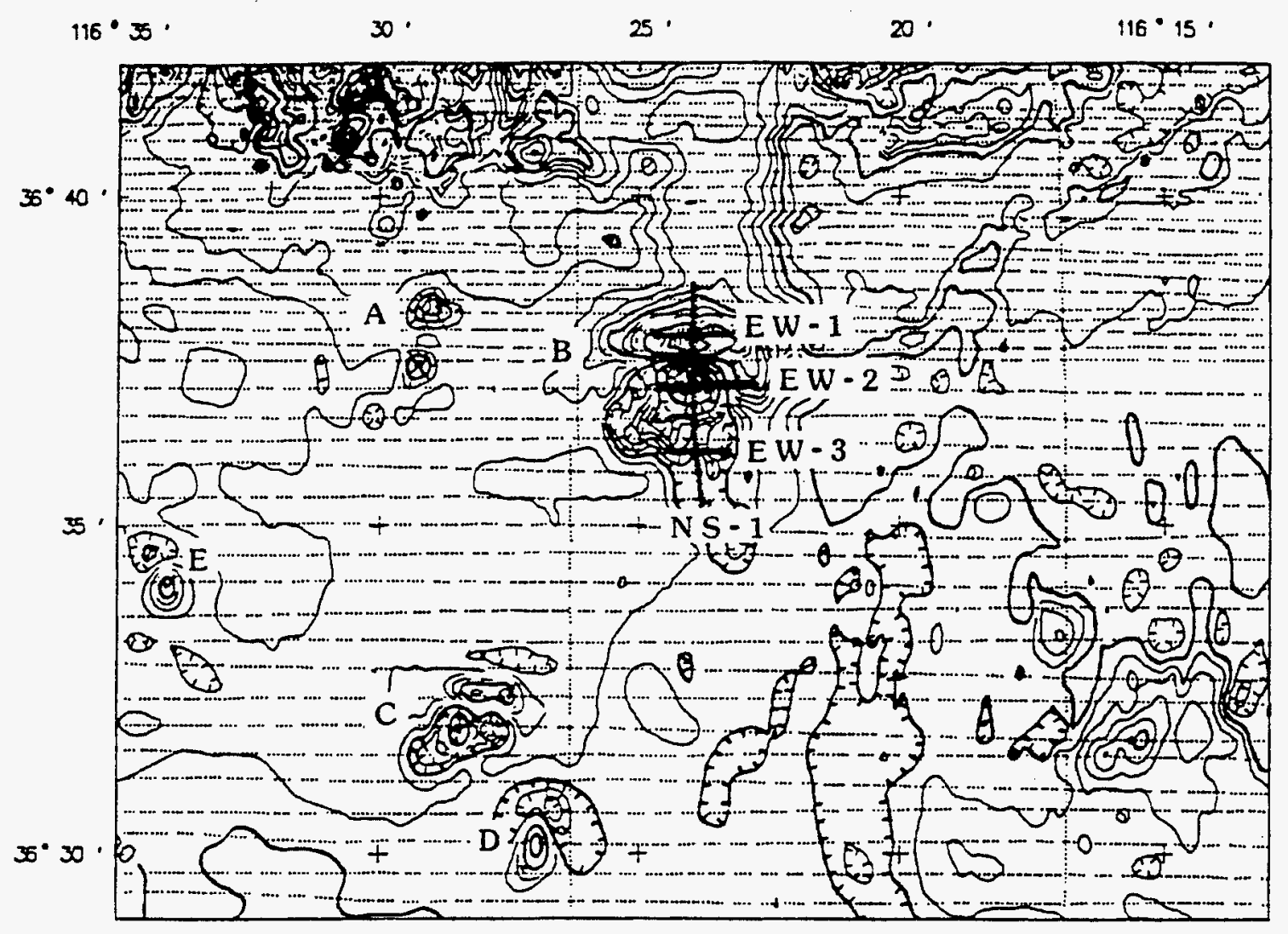

Figure 3.5-Aeromagnetic map of the Lathrop Wells area showing anomalies A to $E$. Thick lines indicate locations of ground magnetic measurements over anomaly B. Dotted lines denote flight-line locations. Contour interval $20 \mathrm{nT}$. Modified from Langenheim and others (1993). 

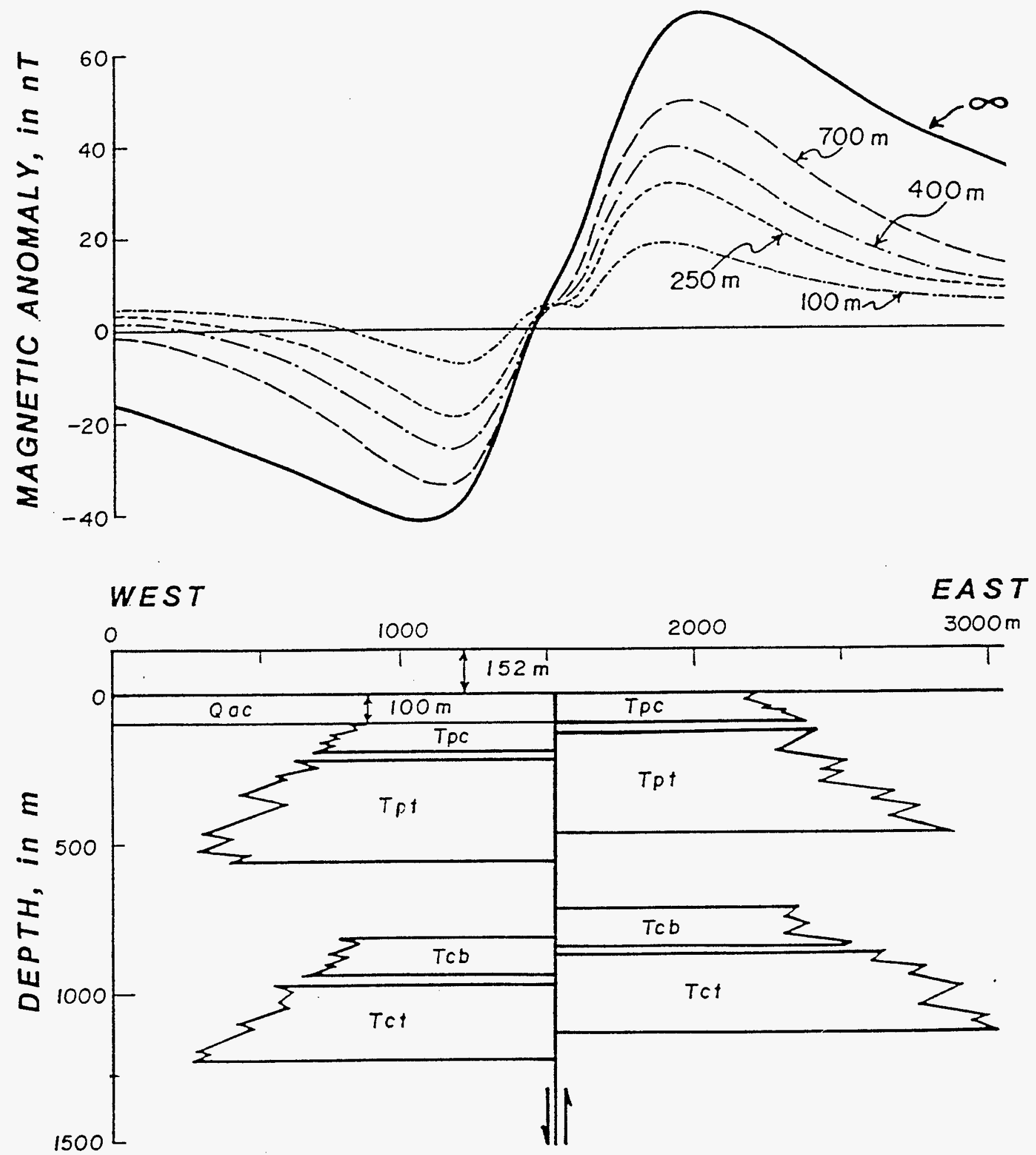

Figure 3.6-Cross section showing theoretical anomalies for total effect of flows of the Tram (Tct) and Bullfrog (Tcb) Tuffs of the Miocene Crater Flat Group and the Topopah Spring (Tpt) and Tiva Canyon (Tpc) Tuffs of the Miocene Paintbrush Group at a fault that strikes north-south. Theoretical anomalies are depicted with increasing vertical displacements down to the west. Modified from Bath and Jahren (1984, fig. 14). 
of $+133 \mathrm{nT}$. Similarly, both the Bow Ridge and Paintbrush Canyon faults in Midway Valley can be identified where concealed by magnetic steps up to the east of about $200 \mathrm{nT}$ and $300 \mathrm{nT}$ at ground level, respectively (Ponce, 1993, fig. 3).

The preliminary results of interpretation of profiles YA to YE in Yucca Wash (fig. 3.7) indicate that the inferred position of the Bow Ridge fault in the vicinity of line $Y B$ needs to be moved about $100 \mathrm{~m}$ to the west. Also, the three ground magnetic profiles of YF show a large (900 to $1250 \mathrm{nT}$ ) anomaly just north of drill hole UE-25 WT\#6. From gradient analysis, the maximum depth to the top of the source is approximately $100 \mathrm{~m}$. Further southeast, there is a broad magnetic high extending to profile YB which coincides with the rise in the water table of about $300 \mathrm{~m}$ between drill holes UE-25 WT\#16 and UE-25 WT\#6 (Langenheim, Ponce, and others, 1993).

Ground magnetic techniques were tested recently for tracing the Ghost Dance fault which runs north-south through the potential repository between the Solitario Canyon fault on the west and the Bow Ridge fault on the east (fig. 3.7). Detailed structural mapping by Spengler and others (1993) indicates that the fault is nearly vertical and offsets strata down to the west by about $30 \mathrm{~m}$. There is no magnetic signature of the fault on aeromagnetic maps of data from lines flown at 150 $\mathrm{m}$ above ground, but new ground measurements have found a distinctive magnetic low of about $400 \mathrm{nT}$ centered only $15 \mathrm{~m}$ east of the fault and flanked by lower amplitude highs stepping up to the east (Oliver and others, 1994), consistent with that found by Bath and Jahren (1984) across the fault in the next canyon to the north. The most promising result of preliminary modeling (Oliver and Sikora, 1994) is a tabular loss of magnetic remanence penetrating the normally polarized Topopah Spring Tuff, perhaps as a result of alteration or brecciation within the fault zone. Modeling further suggests that this signature could also be consistent with some shallow reversely polarized body within the fault plane such as a dike or mineralized zone with a greater reversed polarization than the Tiva Canyon Tuff (Oliver and Sikora, 1994). Such a body could be analogous to the tabular basaltic dike in the Solitario Canyon fault (U.S. Geological Survey, 1984, p. 29), but no geologic evidence for such a body has been found across the Ghost Dance fault trace. Investigations specifically targeting possible basalt in the fault zone have failed to preclude such intrusion(s), but the work suggests low likelihood of basalt: drill holes USW UZN35 and USW UZ-7A were drilled into the Ghost Dance fault plane (Geslin and others, 1995; Geslin and Moyer, 1995) in drainages just north of the magnetic traverse (Oliver and Sikora, 1994) and found no basalt at the shallow depths suggested by the magnetic modeling. In addition; the tunnel-boring machine has excavated the Bow Ridge and Drill Hole Wash faults (R.W. Spengler, personal communication, 1995) and has encountered no basalt in $3300 \mathrm{~m}$ of drift.

\section{OTHER MAGNETIC STUDIES}

Other magnetic studies mentioned in connection with gravity work (chap. 2, this report) are investigations of Syncline Ridge (Ponce and Hanna 1982), and of the Timber Mountain area (Kane and Webring, 1981). The Wahmonie study (Ponce, 1984) is particularly important because 


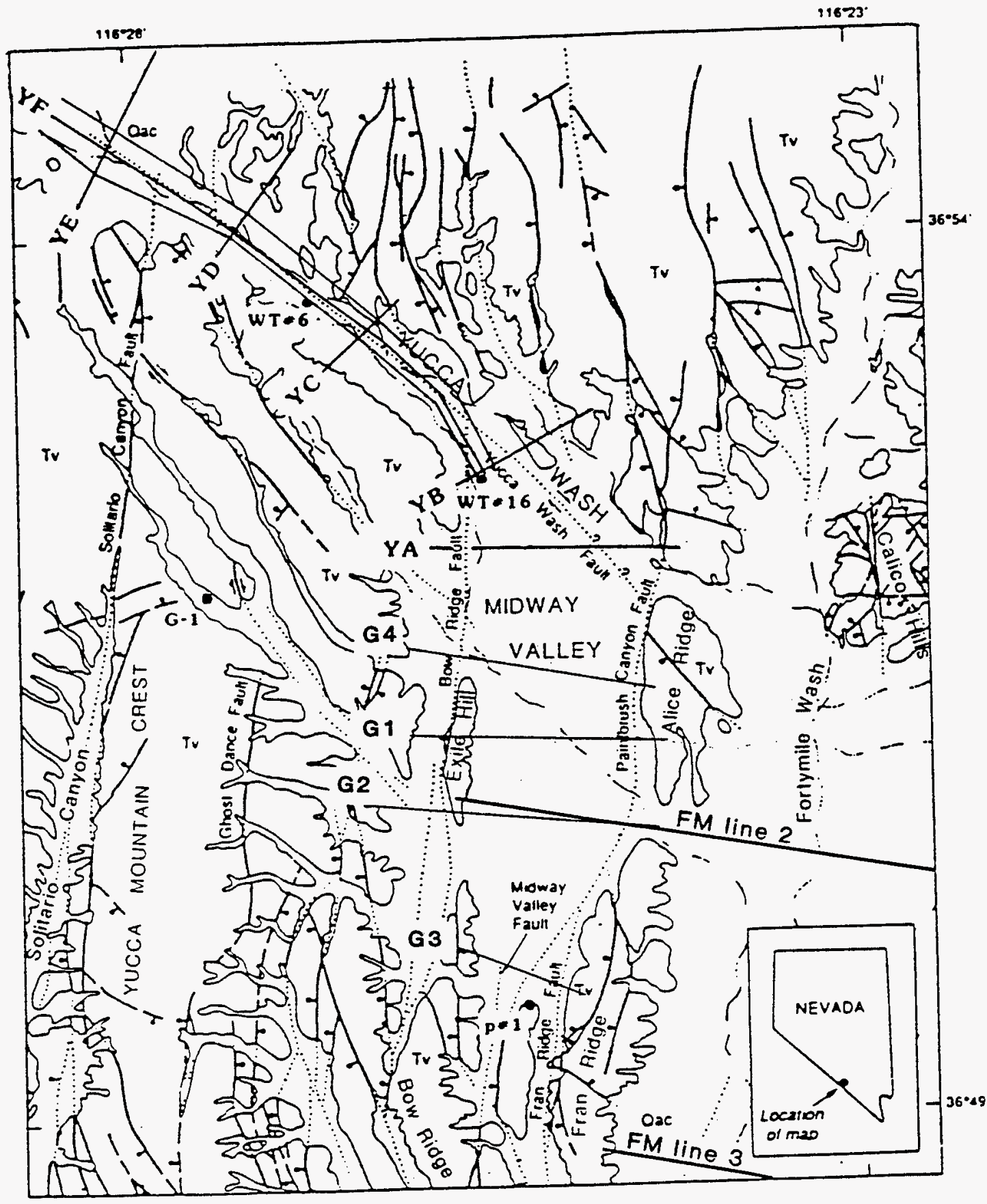

$\underbrace{2}_{1} \underbrace{\mathrm{KM}}$

Figure 3.7. Index map of the study area showing locations of gravity and magnetic profiles along and across Yucca Wash (profiles YA through YF), Midway Valley (profiles GI through G4), and Fortymile Wash (FM profiles), and pertinent drill holes (filled circles). Symbols, Tv, Tertiary volcanic rocks; Qac, Quaternary alluvium and colluvium; bold lines, faults, dotted where concealed, ball and bar on downthrown side, arrows to indicate relative movement. Geology taken from Lipman and McKay (1965). Profile YF consists of three profiles. 
it describes magnetic evidence for a possible intrusive body at shallow depth just east of Yucca Mountain.

A recent analysis of regional magnetic data in the southern Great Basin in terms of depths to the bottom of magnetic sources shows these depths to vary from about $10 \mathrm{~km}$ to about $30 \mathrm{~km}$ (Blakely, 1988). Under Yucca Mountain, the computed depth is about $25 \mathrm{~km}$, although the computation is approaches the southwestern edge of the magnetic data set. There is some rationale to consider these depths as depths to the Curie isotherm $\left(400^{\circ} \mathrm{C}\right.$ to $580^{\circ} \mathrm{C}$ depending on the amount of titanium in the magnetite), and therefore, indicative of major thermal structures. In southern Nevada, there is good correlation between the greater depth $(>25 \mathrm{~km})$ to the base of magnetic rocks and low heat flow values centered about $100 \mathrm{~km}$ north of the Yucca Mountain site (see chap. 9, this report).

\section{LIMITATIONS OF EXISTING AEROMAGNETIC DATA}

Limitations of existing data arise from spacing and focus of previous investigations, as well as from limits of coordination with geologic setting. Aeromagnetic data from traverses spaced at $5 \mathrm{~km}$ were flown in the California part of the southern Great Basin under the National Uranium Resource Evaluation (NURE) Program, and these data are being compiled to enable extension of the Curie isotherm study and analysis of the tectonic problems in this area (see chap. 1). Also, using existing data from traverses flown at $0.5-\mathrm{km}$ spacing over Yucca Mountain, we are attempting to use computer-based redraping methods to isolate the effects of east-west-trending contacts within Paleozoic rocks from the predominately north-south grain of the overlying Cenozoic volcanic units. A merged aeromagnetic map of the Nevada Test Site has been compiled by Kirchoff-Stein and others $(1989)$ at the same scale $(1: 100,000)$ as the recent geologic map (Frizzell and Shulters, 1990), and the results summarized by Oliver and others (1991).

In addition, mosaic aeromagnetic compilations have been made recently of the Las Vegas $1^{\circ}$ by $2^{\circ}$ quadrangle (Saltus and Ponce, 1988), and the Beatty $1 / 2^{\circ}$ by $1^{\circ}$ quadrangle (Glen and Ponce, 1991). Sikora and others (1993) recently compiled all the sources of existing aeromagnetic data within about $140 \mathrm{~km}$ of Yucca Mountain and concluded that the area to the west has the poorest quality as its primary source is the low-level NURE data flown at about $120 \mathrm{~m}$ above ground but with a flight line spacing of about $1.6 \mathrm{~km}$, which is inadequate for locating buried faults and cinder cones (Oliver and others, 1990, p. 17).

\section{CONCLUSIONS}

Existing magnetic data have been very helpful for studying the nature of buried rocks under Yucca Mountain (Oliver and others, 1991; Oliver and Mooney, 1992), for finding buried basaltic cinder cones in Crater Flat and the Amargosa Desert (Langenheim and others, 1993), and for locating concealed faults within Yucca Mountain (Ponce, 1993; Langenheim, Ponce, and others, 1993). Resolution of the aeromagnetic data could be improved by closer flight line 
spacing and more accurate draping. Additional, detailed ground magnetic measurements should be made to help geologists trace concealed faults, and Curie isotherm analysis of the Yucca Mountain region should continue to compare areas of shallow isotherms with areas of high heat flow and recent volcanism. 


\section{REFERENCES CITED}

Bath, G. D., 1968, Aeromagnetic anomalies related to remanent magnetism in volcanic rock, Nevada Test Site, in Eckel, E. B., ed., Nevada Test Site: Geological Society of America Memoir 110, p. 135-146.

Bath, G. D., and Jahren, C. E., 1984, Interpretations of magnetic anomalies at a potential repository site located in the Yucca Mountain Area, Nevada Test Site: U.S. Geological Survey Open-File Report 84-120, 40 p.

Bath, G. D., and Jahren, C. E., 1985, Investigation of an aeromagnetic anomaly on the west side of Yucca Mountain, Nye County, Nevada: U.S. Geological Survey Open-File Report $85-459,24 \mathrm{p}$.

Blakely, R.J., 1988, Curie temperature isotherm analysis and tectonic implications of aeromagnetic data from Nevada: Journal of Geophysical Research, v. 93, no. B10, p. $11,817-11,832$.

Blakely, R.J., Jachens, R.C., and Calzia, J.P., 1994, Regional aspects of the Death Valley extended terrain based on new gravity and magnetic compilations [abs.]: Geological Society of America, Cordilleran Section Meetings, Abstracts with Programs, v. 26, no. 2, p. 38.

Carr, W.D., Grow, J.A., and Keller, S.M., 1995, Lithologic and geophysical logs of drill holes Felderhoff Federal 5-1 and 25-1, Amargosa Desert, Nye County, Nevada: U.S. Geological Survey Open-File Report 95-155, 14 p.

Crowe, B., Morley, R., Wells, S., Geissman, J., McDonald, E., McFadden, L., Perry, F., Murrell, M., Poths, J., and Forman, S., 1992, The Lathrop Wells Volcanic Center: Status of field and geochronology studies: American Nuclear Society, Proceedings of the Third Annual International Conference on High Level Radioactive Waste Management, v. 2, p. 1997-2013.

Crowe, B. M., Vaniman, D. T., and Carr, W. J., 1983, Status of volcanic hazard studies for the Nevada Nuclear Waste Storage Investigations: Los Alamos National Laboratory Report LA-9325-MS.

Frizzell, V.A., Jr., and Shulters, Jaqueline, 1990, Geologic map of the Nevada Test Site, southern Nevada: U.S. Geological Survey Miscellaneous Investigation Series Map I-2046, scale $1: 100,000$.

Geslin, J.K., and Moyer, T.C., 1995, Summary of lithologic logging of new and existing boreholes at Yucca Mountain, Nevada, March 1994 to June 1994: U.S. Geological Survey Open-File Report 94-451, 16 p. 
Geslin, J.K., Moyer, T.C., and Buesch, D.C., 1995, Summary of lithologic logging of new and existing boreholes at Yucca Mountain, Nevada, August 1993 to February 1994: U.S. Geological Survey Open-File Report 94-342, 39 p.

Glen, J.M., and Ponce, D.A., 1991, Aeromagnetic map of the Beatty quadrangle, Nevada and California: U.S. Geological Survey Open-File Report 91-105, scale 1:100,000.

Harris, A.G., Repetski, J.E., Clayton, J.L., Grow, J.A., Carr, M.D., and Daws, T.A., 1992, Results from 1991 wildcat wells near Yucca Mountain, Nevada [abs.]: Geological Society of America Rocky Mountain Section Meetings, Abstracts with Programs, v. 24, no. 6, p. 17.

Hildenbrand, T.G., Rogers, A.M., Oliver, H.W., Harmsen, S.C., Nakata, J.K., Aitken, D.S., Harris, R.N., and Carr, M.D., 1988, Regional geologic and geophysical maps of the southern Great Basin, in Carr, M.D., and Yount, J.C., eds., Geologic and hydrologic investigations of a potential nuclear waste disposal site at Yucca Mountain, southern Nevada: U.S. Geological Survey Bulletin 1790, p. 3-22.

Kane M. F., and Bracken, R. E., 1983, Aeromagnetic map of Yucca Mountain and surrounding regions, southwest Nevada: U.S. Geological Survey Open-File Report 83-616, 19 p.

Kane, M.F., and Webring, M.W., 1981, A preliminary analysis of gravity and aeromagnetic surveys of the Timber Mountain area, southern Nevada: U.S. Geological Survey Open-File Report 81-189, 40 p.

Kirchoff-Stein, K.S., Ponce, D.A., and Chuchel, B.A., 1989, Preliminary aeromagnetic map of the Nevada Test Site and vicinity, Nevada: U.S. Geological Survey Open-File Report 89446 , scale $1: 100,000$.

Langenheim, V.E., Kirchoff-Stein, K.S., and Oliver, H.W., 1993, Geophysical investigations of buried volcanic centers near Yucca Mountain, southwest Nevada: American Nuclear Society, Proceedings of the Fourth Annual International Conference on High Level Radioactive Waste Management, v. 2, p. 1840-1846.

Langenheim, V.E., Ponce, D.A., Oliver, H.W., and Sikora, R.F., 1993, Gravity and magnetic study of Yucca Wash, southwest Nevada: U.S. Geological Survey Open-File Report 93$586-\mathrm{A}, 14 \mathrm{p}$.

Lipman, P.W., and McKay, E.J., 1965, Geologic map of the Topopah Spring SW quadrangle, Nye County, Nevada: U.S. Geological Survey Geologic Quadrangle Map GQ-439, scale $1: 24,000$.

Oliver, H.W., Hardin, E.L., and Nelson, P.H., eds., 1990, Status of data, major results, and plans for geophysical activities, Yucca Mountain Project: U.S. Department of Energy Report YMP 90-38, 236 p. 
Oliver, H.W., Majer, E.L., and Spengler, R.W., 1994, Geophysical investigations of the Ghost Dance fault, Yucca Mountain, Nevada [abs.]: Geological Society of America, Cordilleran Section Meetings, Abstracts with Programs, v. 26, no. 2, p. 78.

Oliver, H.W., and Mooney, W.D., 1992, Characterizing Yucca Mountain, Nevada, by geophysical methods (Extended Abstract): American Geophysical Union 1992 Fall Meeting Abstract Supplement, Abs. T11AA-13, p. 490.

Oliver, H.W., Ponce, D.A., and Sikora, R.F., 1991, Major results of gravity and magnetic studies at Yucca Mountain, Nevada: American Nuclear Society, Proceedings of the Second Annual International Conference on High Level Radioactive Waste Management, v. 1, p. 787-794.

Oliver, H.W., and Sikora, R.F., 1994, Gravity and magnetic data across the Ghost Dance fault in WT-2 Wash, Yucca Mountain, Nevada: U.S. Geological Survey Open-File Report 94413-A, $20 \mathrm{p}$.

Ponce, D.A., 1984, Gravity and magnetic evidence for a granitic intrusion near Wahmonie Site, Nevada Test Site, Nevada: Journal of Geophysical Research, v. 89, no. B11, p. 9401-9413.

Ponce, D.A., 1993, Geophysical investigations of concealed faults near Yucca Mountain, southwest Nevada: American Nuclear Society, Proceedings of the Fourth Annual International Conference on High Level Radioactive Waste Management, v. 1, p. 168-174.

Ponce, D.A., and Hanna, W.F., 1982, Preliminary appraisal of gravity and magnetic data at Syncline Ridge, western Yucca Flat, Nevada Test Site, Nye County, Nevada: U.S. Geological Survey Open-File Report 82-931, 19 p.

Ponce, D.A., Kohrn, S.B., and Waddell, Sandra, 1992, Gravity and magnetic data of Fortymile Wash, Nevada Test Site, Nevada: U.S. Geological Survey Open-File Report 92-343, 33 p.

Ponce, D.A., Langenheim, V.E., and Sikora, R.F., 1993, Gravity and magnetic data in Midway Valley, southwest Nevada: U.S. Geological Survey Open-File Report 93-540A, 7 p; 93 $540 B$, Geophysical data on diskette.

Saltus, R. W., and Ponce, D. A., 1988, Aeromagnetic map of Nevada, Las Vegas sheet: Nevada Bureau of Mines and Geology Map 95, scale 1:250,000.

Sawyer, David A., Fleck, R.J., Lanphere, M.A., Warren, R.G., Broxton, D.E., Hudson, Mark R., 1994, Episodic caldera volcanism in the Miocene southwestern Nevada volcanic field: Revised stratigraphic framework, ${ }^{40} \mathrm{Ar} /{ }^{39} \mathrm{Ar}$ geochronology, and implications for magmatism and extension: Geological Society of America Bulletin, v. 106, p. 1304-1318. 
Sikora, R.F., Ponce, D.A., and Oliver, H.W., 1993, Status of aeromagnetic survey coverage of Yucca Mountain and vicinity to a radius of about 140 kilometers, southwestern Nevada and southeastern California: U.S. Geological Survey Open-File Report 93-44, 17 p.

Spengler, R.W., Braun, C.A., Linden, R.M., Martin, L.G., Ross-Brown, D.M., and Blackburn, R.L., 1993, Structural character of the Ghost Dance fault, Yucca Mountain, Nevada: American Nuclear Society, Proceedings of the Fourth Annual International Conference on High Level Radioactive Waste Management, v. 1, p. 653-659.

U.S. Geological Survey, 1984, A summary of geologic studies through January 1, 1983, of the potential high-level radioactive waste repository at Yucca Mountain, southern Wye County, Nevada: U.S. Geological Survey Open-File Report 84-792, 103 p.

Walker, G.E., and Eakin, T.E., 1963, Geology and ground water of Amargosa Desert, NevadaCalifornia: State of Nevada Department of Conservation and Natural Resources Ground Water Resources Reconnaissance Series Report 14, 45 p., 4 plates.

72 


\title{
MAJOR RESULTS OF GEOPHYSICAL INVESTIGATIONS AT YUCCA MOUNTAIN AND VICINITY, SOUTHERN NEVADA
}

\section{CHAPTER 4: REGIONAL MAGNETOTELLURIC INVESTIGATIONS}

\author{
By Douglas P. Klein
}

\section{INTRODUCTION}

This chapter discusses the status of magnetotelluric (MT) investigations in the region of the potential nuclear waste storage site at Yucca Mountain, which is located on the western margin of the Nevada Test Site, southern Nevada (fig.4.1). The objective of MT surveys is to characterize the subsurface resistivity structure in relationship to subsurface geologic and hydrologic conditions and various tectonic processes of the deep crust. Several MT surveys have been performed in the Yucca Mountain region from 1965 to 1986. The MT surveys were performed to investigate local crustal conditions as well as to provide regional information that could be integrated with tectonic studies. Most of the published records of the MT data focus on site-specific studies (Hoover, 1982b,c) or deal with specific surveys (Furgerson, 1982). This chapter will emphasize the regional aspects of magnetotelluric studies and various MT data. The earlier surveys (Hoover and others, 1982b,c; Furgerson, 1982) contribute significantly to our understanding of the deep geoelectric conditions of the region and were useful in the design of the most recent MT survey by the U.S. Geological Survey (USGS) in 1986. The 1986 survey (fig. 4.1), was undertaken to fill gaps left by the previous surveys, and was intended to provide traverses with soundings at spacings of $5 \mathrm{~km}$ across several major geologic features believed to be important to understanding the tectonic setting of Yucca Mountain. As noted elsewhere in this volume, constraints of funding and availability of method impacted various investigations. A previous geophysical compilation (Oliver and others, 1990) provides additional details of electrical investigations at Yucca Mountain.

Magnetotelluric surveys may be used to address several questions relating to the characterization of the Yucca Mountain region; including (1) lateral variations in crustal strength as revealed by deep faulting or changes in the deep-crustal fluid and thermal regime; (2) extent and orientation of high-angle fault zones; (3) extent of low-angle middle Tertiary extensional faults or Mesozoic thrust faults; (4) existence of crustal plutons and magma chambers; and (5) patterns of deep, conductive, hydrologic zones, as revealed by probable fault or fracture patterns or aquifers and aquitards.

Magnetotelluric (MT) profiles acquired or planned at the onset of the 1986 survey traverse the Furnace Creek-Death Valley Fault zone (fig. 4.1) and tie into an area of a suspected magma chamber in the southern part of Death Valley (deVoogd and others, 1986). Death Valley and the Furnace Creek-Death Valley Fault Zone occur in the transition zone between markedly different crustal thickness of about $30 \mathrm{~km}$ for southern Nevada, to more than $40 \mathrm{~km}$ for the Sierra Nevada region (Thompson and Burke, 1974). The traverses also span the Walker Lane structural belt (Carr, 1984), which is a zone of deformation 


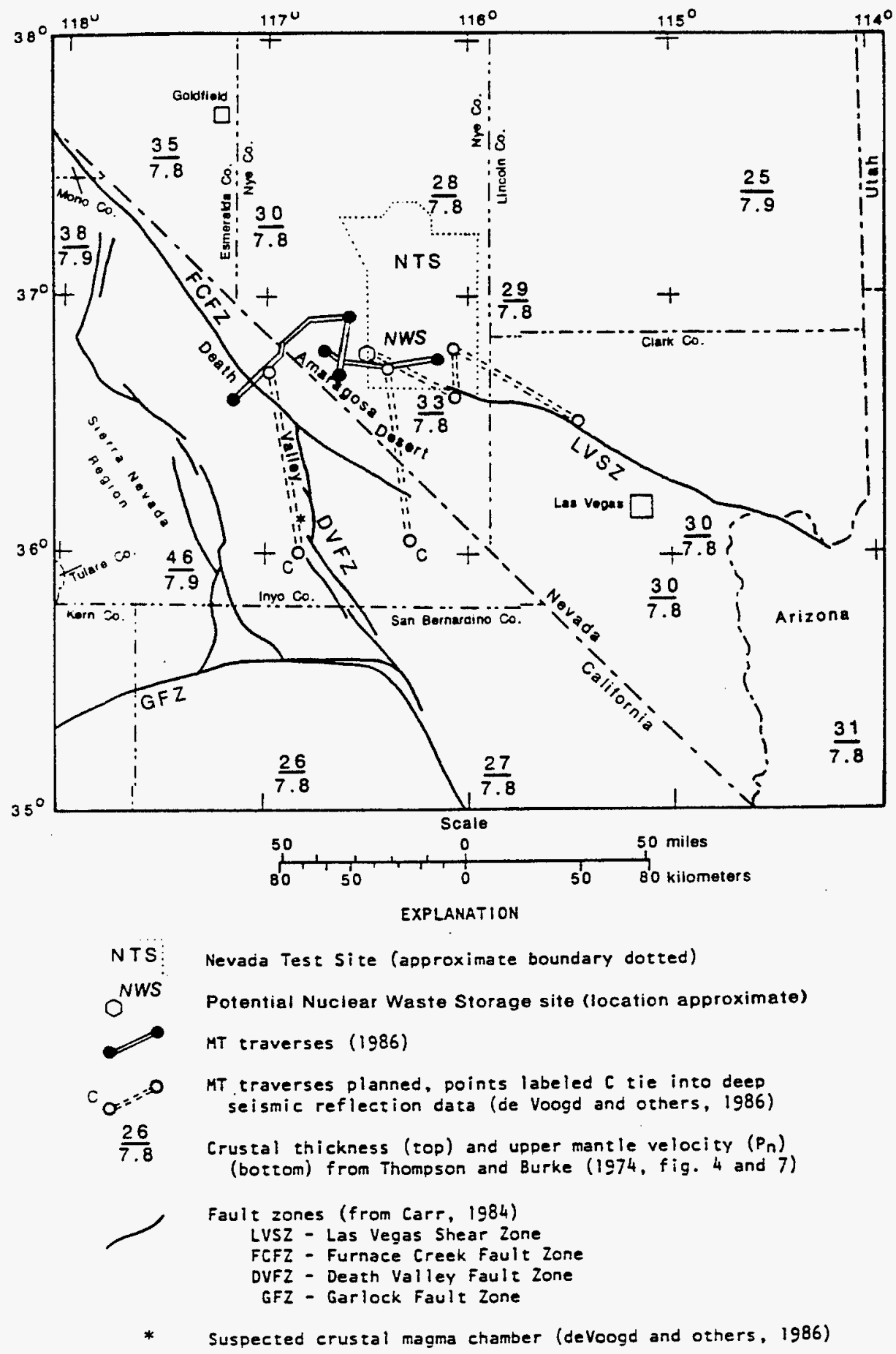

Figure 4.1. Location map of the Nevada Test Site showing the location of USGS magnetotelluric traverses acquired or planned in 1986. Also shown are major fault zones, crustal thickness, and upper mantle velocities. 
roughly bounded by the Las Vegas Shear Zone and the Furnace Creek-Death Valley Fault Zone. In the western Amargosa Desert, the MT survey crosses an area underlain by middle Tertiary detachment faults. Just west of the potential repository (fig. 4.1), the survey traverses Crater Flat, a site of basaltic volcanism within the last $2 \mathrm{~m} . \mathrm{y}$. and which may also have been the site of middle Tertiary rhyolitic volcanism and caldera formation (Snyder and Carr, 1984; Carr, 1988). The relative importance of extensional tectonics versus volcano tectonics in the area of Crater Flat is largely unknown. Eastward, the MT survey crosses Yucca Mountain and Jackass Flats and is planned to traverse the Rock Valley Fault Zone, which displays a northeast-trending zone of anomalous seismicity (Rogers and others, 1983) across the southeastern part of the Nevada Test Site.

\section{MAGNETOTELLURIC METHOD}

Magnetotelluric surveys use surface measurements of the Earth's natural timevarying electric $(\mathrm{E})$ and magnetic $(\mathrm{H})$ fields to deduce the resistivity distribution in the subsurface. Electrical resistivity (ohm- $\mathrm{m}$, the inverse of electrical conductivity) is a measure of ability to impede electrical current. The resistivity of rocks is related to crustal processes, geologic structure and lithology, chiefly through variations in pore fluids, temperature, or alteration patterns in the rock strata. Modern MT methods measure at least four components of the time-varying $\mathrm{E}$ and $\mathrm{H}$ fields (Vozoff, 1972; Clarke and others, 1983). The essential components consist of horizontally perpendicular $\mathrm{E}$ and $\mathrm{H}$ fields. Measurements often include the vertical $H$ field, however, which when combined with the horizontal $\mathrm{H}$ fields provides additional information on the electrical strike. Supplementary data also include $\mathrm{E}$ and (or) $\mathrm{H}$ fields at a site remote from the primary sensors. The latter measurements provide a means of evaluating and reducing the effects of noise in the data (Clark and others, 1983).

The relationship between the various horizontal $\mathrm{E}$ (electrical) and $\mathrm{H}$ (magnetic) fields is known as the MT response function or impedance tensor, written as $\mathrm{Ei} / \mathrm{Hj}$ or $\mathrm{Zij}$. This frequency-dependent tensor contains the information from which we can infer the Earth's electrical structure. The response function is usually presented for the elements Zxy and Zyx which are rotated to minimize the elements $\mathrm{Zxx}$ and Zyy. Sounding curves are plots of the impedance-tensor elements against frequency. These MT sounding curves comprise the working data for interpretation. Examples of MT soundings acquired by the USGS in 1986 are shown on figure 4.2. The data are usually plotted as apparent resistivity ( $\mathrm{Rxy}$ and $\mathrm{Ryx}$, ohm-m) and phase rather than in measured units of $\mathrm{Zij}$, which is ohms. In addition to the apparent resistivity and phase curves, coherency is plotted with the soundings (fig. 4.2). Coherency is a measure of the noise in the data, ranging from 0 to 1 , with higher coherency indicating better parts of the sounding curve. Also shown (fig. 4.2) are the one-dimensional (1-D) models and computed responses which approximate parts of these curves. It can be noted that 1-D models cannot account for the divergence between Rxy and Ryx. This divergence between the elements of the impedance tensor is useful 

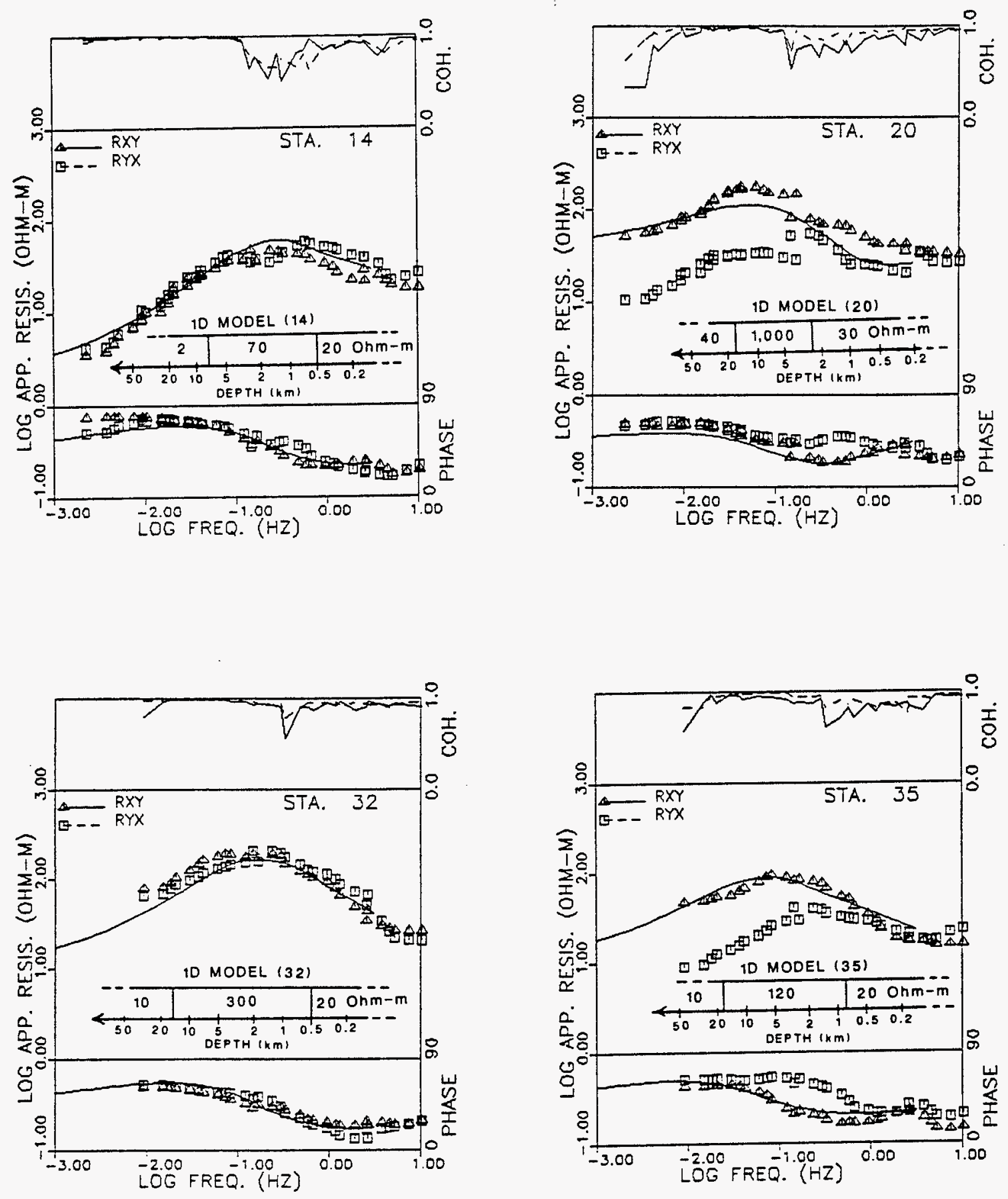

Fig. 4.2-Examples of MT sounding curves from data acquired by the USGS in 1986 . For each sounding, observed apparent resistivity amplitude (middle) and impedance phase (bottom) are shown by triangles for the tensor component $\mathrm{Rxy}$ (Ex/Hy) and squares for the component Ryx (Ey/Hx). Coherency is shown at the top of each sounding as solid lines for Rxy and dashed lines for Ryx. Solid lines (middle and bottom) are the calculated 1-D apparent resistivity and phase response for the resistivity/depth variations shown. 
in determining the dimensionality of the resistivity distribution. When Rxy and Ryx diverge, the method is sensing 2- or 3-dimensional structures. Alternate indications of 2- or 3dimensionality are indicated by non-zero values of the $\mathrm{Hz}$ field or of the Zxx and Zyy impedance elements.

Electromagnetic field penetration is a function of frequency, and MT data at various frequencies therefore provide the means to distinguish spatial variations in resistivity both laterally and vertically. However, the distance of MT investigation is also dependent on the resistivity of the strata. The principles of electromagnetic induction show that the fields are attenuated exponentially as a function of the quotient of resistivity over frequency. Thus, the penetration of MT fields increases with higher resistivity and lower frequency. In a particular geoelectric setting, lower frequencies penetrate further. In southern Nevada, MT data at frequencies of 0.001 to $10 \mathrm{~Hz}$ typically provide information for the depth range of about 1 to $30 \mathrm{~km}$. The effects of lateral inhomogeneities may be seen at equivalent distances. Both the absolute value of resistivity and its spatial variations are of interest in inferring the structure and composition of the rocks penetrated. The resolution of electrical structure and resistivity, however, are dependent on the depth of penetration. Inasmuch as MT fields at a particular frequency or depth of penetration are influenced to some degree by all rocks penetrated at higher frequencies (or shallower depths), the resolution decreases at lower frequencies. There is no generalized rule to estimate the limits of resolution because of other factors besides frequency, including noise in the measurements and the complexity of resistivity structure. The maximum curvatures in MT sounding curves are constant on $\log -\log$ scale, however, which indicates that the resolution decreases proportionally to the $\log$ of depth or resistivity. For example, resolution limits of 10 to $30 \mathrm{ohm}-\mathrm{m}$ for resistivity and 100 to $150 \mathrm{~m}$ for depth imply an analogous resolution of 100 to $300 \mathrm{ohm}-\mathrm{m}$ and 1,000 to $1,500 \mathrm{~m}$.

\section{EARTH RESISTIVITY}

The geological application of MT and other electrical geophysical methods is closely tied to research that relates electrical resistivity and its variations to the composition and temperature of the Earth. Brace (1977), Olhoeft (1981), and Shankland and Ander (1983) provide reviews of such relationships appropriate for depths extending to the base of the crust, or about 20 to $50 \mathrm{~km}$. Keller and Frischknecht (1966) discuss the resistivity of rocks for conditions typical of the upper 1 or $2 \mathrm{~km}$ of the Earth.

Pore fluids in crustal rocks have resistivity that is orders of magnitude less than the mineral-grain resistivity (Brace, 1977; Kariya and Shankland, 1983; Shankland and Ander, 1983). Therefore, resistivity in the upper crust, and perhaps throughout most of the crust, is largely dependent on the temperature, volume fraction, connectivity and ioniccomposition of fluid contained in the strata (Olhoeft, 1981; Shankland and Ander, 1983; Hyndman and Shearer, 1989; Hyndman and Klemperer, 1989). Moreover, there can be large variations in the resistivity of pore fluid as well as the volume of fluid, both of which are controlled by various geologic processes. Fluid resistivity is decreased by increasing 
either temperature (up to the vapor point when resistivity is again high) or by increasing equivalent salinity or ionic content. Surface conduction caused by the ionic exchange between minerals and pore fluids at the pore interface is also important in decreasing the bulk resistivity of rocks (Olhoef, 1981) and is dependent on the composition of the pore walls. Minerals that enhance this effect include clay or zeolite minerals which are commonly associated with altered volcanic rocks. Thus, the presence of alteration can be a major factor in producing low-resistivity zones associated with faulting or volcanic ash

flows such as found in the stratigraphic section at Yucca Mountain (Frischknecht and Raab, 1984).

Compared to free water, the effect of bound water in hydrous minerals such as amphibole and serpentine is usually of second-order importance (Olhoeft, 1981). In the deeper parts of the crust, however, metamorphic reactions involving such minerals may be an important source for resistivity anomalies in that free water is a dynamic variable dependent on tectonic activity. The amount of free water required to lower resistivity of rocks by orders of magnitude is in the range of 1 to 5 percent, dependent on salinity.

Because of the large effects of factors that control ionic conduction in fluids, variations among mineral resistivities can usually be ignored (Olhoeft, 1981). Anomalously conductive minerals exist, however, and may occur in sufficient volume to be detectable; conductive minerals include graphite and most metallic minerals and sulfides (Olhoeft, 1981; Keller, 1982). Magma is also conductive (Lebedev and Khitarov, 1964), and the bulk resistivity of crustal rocks can be significantly lowered by the presence of partial melts in volume fractions as small as 3 percent (Waff, 1974, Waff and Weill, 1975).

\section{MAGNETOTELLURIC SURVEYS AT THE NEVADA TEST SITE}

In the period from 1965 to 1986 , there have been $133 \mathrm{MT}$ stations reported for the vicinity of the Nevada Test Site. In addition to MT surveys, there have been controlledsource studies and high-frequency natural-source studies to investigate the shallower crustal structure in selected areas to depths of about $1 \mathrm{~km}$. Some of the detailed shallow studies were reviewed by Hoover $(1982 \mathrm{~b}, \mathrm{c})$. The high-frequency natural-source electrical work includes audio-frequency ( 1 to $20,000 \mathrm{~Hz}$ ) MT surveys (GTE Sylvania Incorporated, 1975; Westinghouse Electric Corporation, written commun., 1978; and Zablocki, 1979), and telluric surveys (Zablocki, 1979; Hoover and others, 1982a,c). These controlled-source and shallow-penetrating natural-source surveys, as well as drill hole logs, can be useful to constrain MT modeling for the shallow layers, but they are usually carried out across small areas and are thus not reviewed here.

The first MT soundings at the Nevada Test Site (Plouff, 1965, 1966) were acquired at Yucca Flat (sounding 11) and Wahmonie Flat (sounding 12). These soundings (0.001 to $3 \mathrm{~Hz}$ ) are based on two components (H-north [magnetic] and E-east [electric]) and thus modern tensor analysis was not applied. Possible effects of 2- or 3-D structure cannot be evaluated for these data. Based on a 3-layer modeling technique, Plouff (1965) estimated 
that the resistive part of the crust $(250 \mathrm{ohm}-\mathrm{m}$ or greater) in the Nevada Test Site area was about 25 to $36 \mathrm{~km}$ thick, with a probable maximum thickness of $50 \mathrm{~km}$. The typical resistivity in the lower crust was estimated at 4 to $12 \mathrm{ohm}-\mathrm{m}$ with a probable maximum of 20 to $40 \mathrm{ohm}-\mathrm{m}$ (Plouff, 1966, Table I). These results are in general accord with more recent results reviewed below, but the data are less amenable to modern methods of analysis and 2-D modeling.

The first modern, five-component, tensor MT survey at the Nevada Test Site consisted of 12 soundings $(0.002$ to $250 \mathrm{~Hz})$ in the area of Yucca Flat. These data are described in an unpublished report (D.R. Word and others, written commun., 1977) acquired under contract to Lawrence Livermore Laboratories (Hoover, 1982c, p.8). The data were modeled using a 1-D assumption, and the results were presented as composite sections of the 1-D models. Soundings 1 through 10 are closely spaced on two parallel northwest-southeast profiles located about $4 \mathrm{~km}$ south of Quartzite Ridge in northern Yucca Flat. The profiles are $1 \mathrm{~km}$ apart and each profile is $2.1 \mathrm{~km}$ long. Each profile consists of five soundings. Both composite sections generally show a low-resistivity zone of $10 \mathrm{ohm}-\mathrm{m}$ or less at a depth of 1 to $2 \mathrm{~km}$ on the northwest, deepening to about 5 to $6 \mathrm{~km}$ on the southeast. Soundings 11 and 12 are more centrally located in Yucca Flat. These two soundings are $10 \mathrm{~km}$ south of the two detailed profiles just described and are spaced about $6.5 \mathrm{~km}$ apart in an east-west direction. The 1-D models for soundings 11 and 12 show a low-resistivity zone of $10 \mathrm{ohm}$-m or less at a depth of $2 \mathrm{~km}$ on the east (sounding 11 ), and $8 \mathrm{~km}$ on the west (sounding 12). The models show further-decreasing resistivity with depth to values below $1 \mathrm{ohm}-\mathrm{m}$. Maximum penetration indicated by the models (D.R. Word and others, written commun., 1977) was less than $15 \mathrm{~km}$. Based on these 1-D models, a major feature in the central to northern Yucca Flat area is a low-resistivity zone (10 ohm-m or less) at depths below 2 to $6 \mathrm{~km}$. The composite sections show an eastward or southeastward dip on the zone with about a 1:1 slope. A more discontinuous relief is possible. The conductive unit may be related to an argillic unit, brine-saturated sedimentary rocks, or elevated temperatures. The structure is probably a major fault zone beneath Yucca Flat. Detailed aspects of the model as posed by the 1-D section are subject to significant uncertainties without further 2- or 3-D modeling. Significant (20 to 30\%) uncertainty in the models is reasonable (D.R. Word and others, written commun., 1977).

The USGS contracted for an extensive MT survey that encompasses much of the southern Nevada Test Site area (Hoover, 1982c, p. 46). The contracted survey occupied 60 locations, utilizing a five-component tensor MT system with frequencies in the range of 0.001 to $25 \mathrm{~Hz}$. The data (Williston, McNeil and Associates, written commun., 1979), show pronounced scatter amounting to 1 or $2 \mathrm{log}$ cycles for many soundings. Examples of five soundings (19, 14, 20,13 and 15) from the Calico Hills area are shown by Hoover and others (1982b). Scatter in the sounding curves is unacceptable for quantitative modeling in most cases. The better sounding curves are 4, 18, 20,25,32, and 44, which show reasonable indications of the shape of the curve across the full frequency range with a scatter of about $0.5 \mathrm{log}$ cycles or less on the average. Inasmuch as many of the curves have multiple estimates of apparent resistivity and phase at each frequency, further smoothing of the data would be possible. 
Four-layer models for 26 soundings (Williston, McNeil and Associates, written commun., 1979, table 2) were presented. Another 31 soundings were interpreted to provide either the depth to the deep conductor, the conductance of the upper crust, or both. Three soundings were not interpretable. Inasmuch as the modeled response curves are not presented, the models cannot be evaluated without duplicating the modeling. Preliminary analysis submitted by Williston, McNeil and Associates (written commun., 1978) shows more interpretable (smoother) curves for soundings 1 through 20 than do results for the same soundings presented in the final report. Soundings 1 through 20 are in the areas of Syncline Ridge, Yucca Flat, Jackass Flats, and Calico Hills. There are differences between some of the sounding curves shown in the preliminary submittal compared to the final submittal, as well as differences in the models inferred from the same soundings. The differences are not explained; there was clearly a variation in the processing, however, as well as in the modeling, inasmuch as only one of these soundings (2) was indicated to be a repeat measurement. Results of the 1-D modeling were presented as composite sections on four profiles (Williston, McNeil and Associates, written commun., 1979). Profile 1 traverses northwest to southeast across Syncline Ridge with six soundings; this profile is shown and discussed by Hoover (1982c). Profile 2, which is comprised of 15 soundings, traverses north-south across the Amargosa Desert and extends northward along Fortymile Wash; this profile will be discussed below. Profiles 3 and 4 comprised of a total of 16 soundings cross the southern part of Yucca Mountain in a generally east-west direction. In addition to the profiles just described, Hoover and others (1982b) presented a composite profile based on five soundings listed above that extends north-south into the Calico Hills area. Two major features in the models of Williston, McNeil and Associates (written commun., 1979) are (1) a deep low-resistivity zone at 10 to $50 \mathrm{~km}$ (an average depth of about $20 \mathrm{~km}$ ) seen in all four profiles, and (2) a shallow, thin, low-resistivity zone at depths of 2 to $5 \mathrm{~km}$, which is modeled along segments of the profiles that span three to nine soundings in the areas of Syncline Ridge, the southern part of Yucca Mountain and part of Crater Flat, and along Fortymile Wash on the eastern flank of Yucca Mountain.

Furgerson (1982) reported on the first remote-reference, seven-component, tensor MT survey in the Nevada Test Site region. This data set is composed of 16 soundings in the frequency range of 0.001 to $100 \mathrm{~Hz}$ (fig. 4.3). Neither the data nor an analysis is presented for sounding 27, located in the Mormon Mesa region north of Las Vegas (Furgerson, 1982), but sounding 27 is integrated with the data of Meredith and Frischknecht (1989, their sounding A27). The sounding curves presented by Furgerson are smooth and dependable as indicated by the estimated errors shown with the curves. The high quality of these data results largely from the use of the remote reference technique for noise suppression. The soundings are widely spaced, however, and do not generally allow interpolation of results between soundings. Intervals between soundings (fig. 4.3) range from 7 to $52 \mathrm{~km}$, with a median of about $29 \mathrm{~km}$. Furgerson (1982) provides 1-D models for each sounding. Seven of the inverted soundings were used to construct a composite north-south geoelectric section across the southern part of the Nevada Test Site. In general, the 1-D interpretations indicate low crustal resistivity (10 ohm-m or less) at depths 


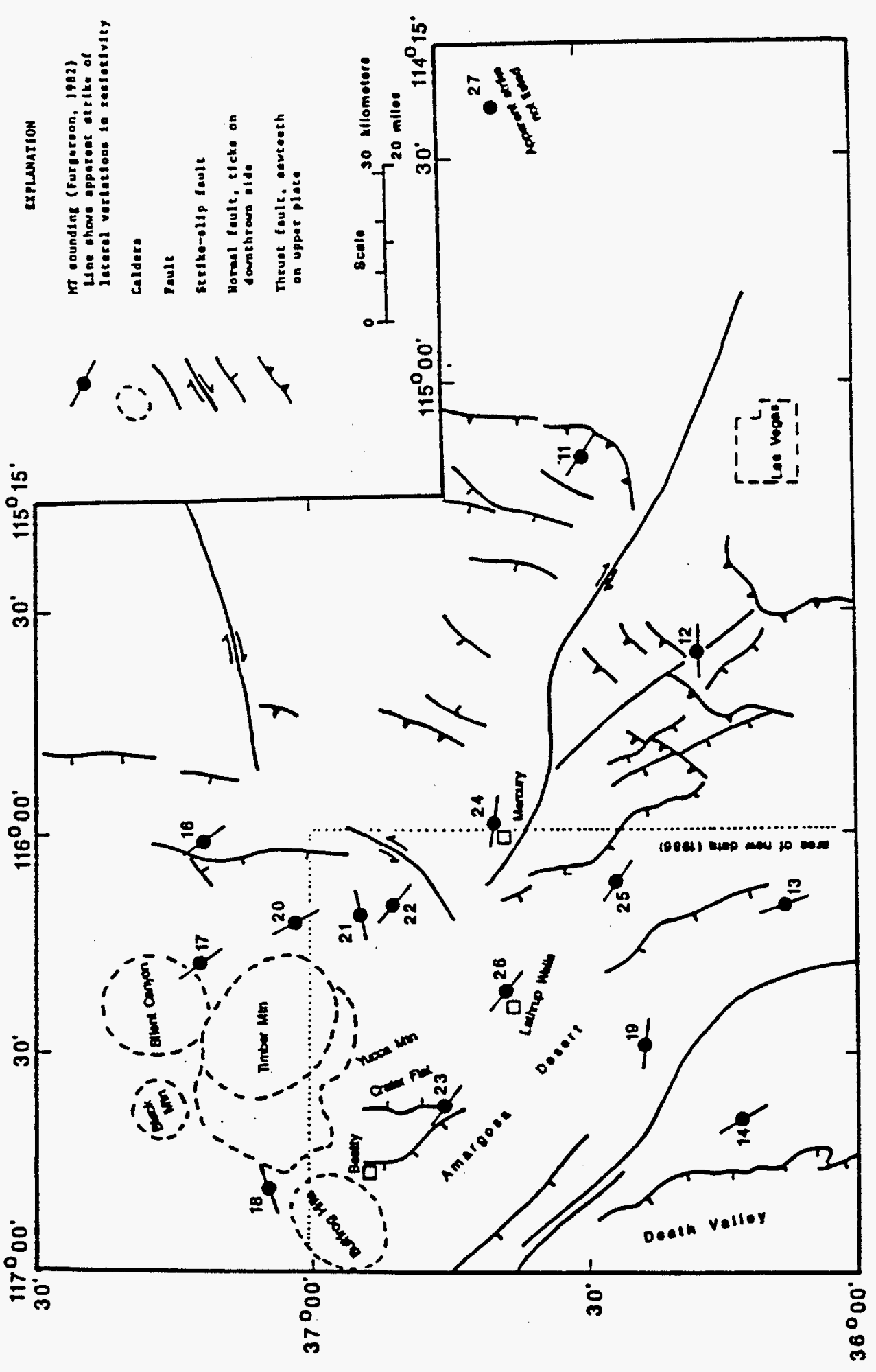

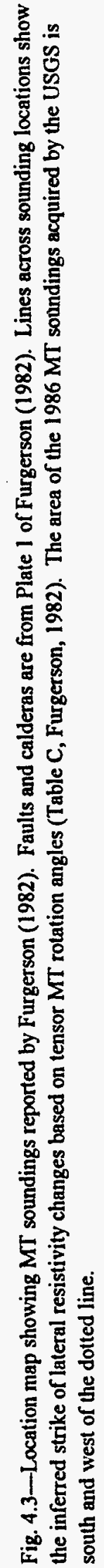


in the range of about 5 to $20 \mathrm{~km}$. The models also suggest a thin low-resistivity unit beneath some areas. Variations in the resistivity of units in the upper $3 \mathrm{~km}$ of the crust range from about $10 \mathrm{ohm}-\mathrm{m}$ to more than $1,000 \mathrm{ohm}-\mathrm{m}$. All soundings show clear evidence of significant lateral resistivity changes. The apparent strikes of the resistivity structures as determined by the relationship of the vertical to horizontal magnetic variations are shown on figure 4.3. The strikes indicate a generally consistent picture of a western to northwestern regional strike in electrical structure.

In April 1986, the USGS performed part of a planned series of new MT measurements $(0.001$ to $20 \mathrm{~Hz})$ centered on Yucca Mountain. The location of the 35 soundings obtained in 1986 are shown in figure 4.4. The approach used in that survey was based on previous MT results that unanimously point to the need to have soundings spaced at distances no greater than about $5 \mathrm{~km}$. To account fully for possible 2- and 3-D nearsurface effects would require even closer spacings (of the order of $1 \mathrm{~km}$ ), but this spacing did not seem feasible. Furthermore, although the remote-reference technique has advantages in data acquisition and processing, the cost is high, and the result would be fewer, although more precise, soundings. The survey was thus carried out with singlestation (four-component) measurements using a nominal spacing of $5 \mathrm{~km}$ along selected profiles. Sounding curves from four of the 1986 soundings are shown (fig. 4.2). Examples of the results of preliminary field analysis and 1-D interpretations of the data are also illustrated. Further work to quantify the lateral and vertical resistivity variations is in progress.

\section{IMPLICATIONS OF MAGNETOTELLURIC DATA}

There has been only limited application of the available MT data in the characterization of regional geology in the Nevada Test Site region. Furgerson (1982) briefly commented on regional implications of his MT strike data. Most interpretations, however, have been limited to specific site investigations. Hoover and others $(1982 \mathrm{~b}, \mathrm{c})$ discussed some of the MT data from D.R. Word and others (written commun., 1977) and Williston, McNeil and Associates (written commun., 1979) that were pertinent to the characterization of the Syncline Ridge, Wahmonie and Calico Hills areas. In Yucca Flat east of Syncline Ridge, MT data suggest a major north-striking electrical discontinuity (Hoover and others, 1982c). Hoover and others (1982c) also suggest that inferred low resistivity in the area of Syncline Ridge may reflect enhanced temperatures at shallow crustal depths of 3 to $11 \mathrm{~km}$. In the Calico Hills area, inferred high resistivity in the range of 4,000 to 6,000 ohm-m beneath parts of that area (Williston, McNeil and Associates, written commun., 1979) may indicate an intrusion at depths as shallow as $3 \mathrm{~km}$ (Hoover and others, 1982b). Hoover and others (1982b,c) emphasized the considerable uncertainty in the depth estimates due to the large scatter in these data and the possible effects of 2- or 3-D structural complexities which were not taken into account in the MT analysis. 
(IL6I) sumplo

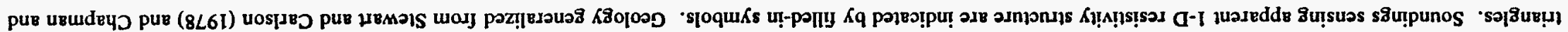

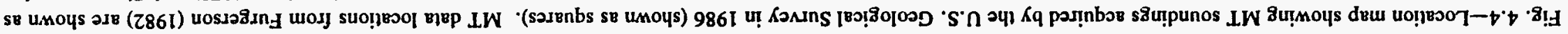
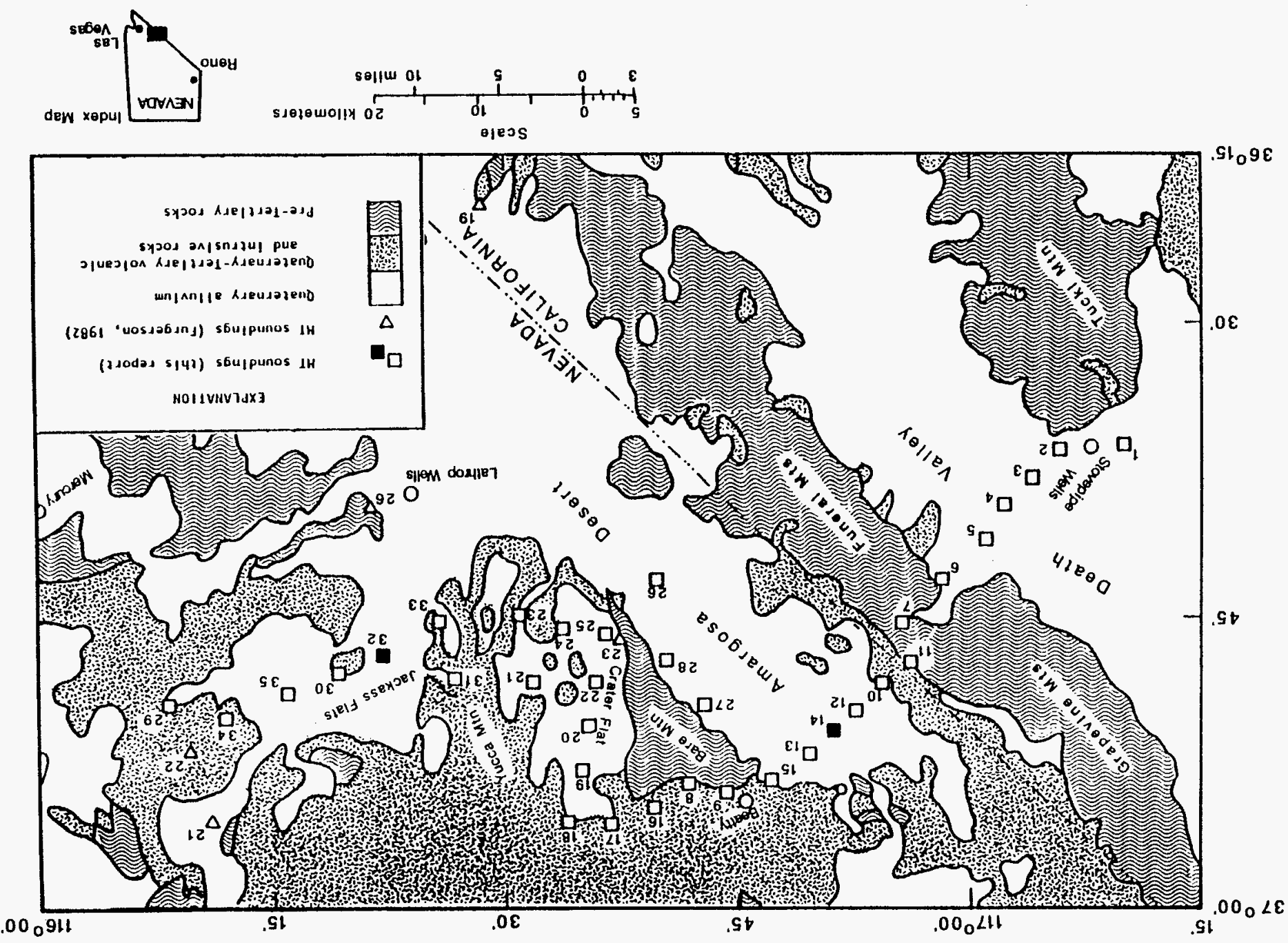
On a regional scale, Furgerson's (1982) frequency-averaged rotation angles based on $\mathrm{Hz}$ (vertical magnetic) data from 15 soundings (fig. 4.3) indicate a dominant west to northwest electrical strike that indicates conductive anisotropy aligned in that direction. This strike roughly agrees with the trend of the Walker Lane belt (Stewart, 1980, fig.3, p.80; Carr, 1984), a belt of inferred crustal mobility of probable Mesozoic age and the location of more recent Miocene volcanism. The Walker Lane belt roughly follows a zone whose boundaries are marked by the Las Vegas Shear Zone and the Furnace Creek and Death Valley Fault Zone (fig. 4.1). One possible inference from the rotation data is the existence of a swath of deep west- to northwest-striking faults or fractures that are either significantly altered or contain anomalous concentrations of conductive fluids. Such concentrations of fluids would be reasonably explained by zones of anomalous fracture porosity along fault zones. An alternative inference is that there may be one or two major discontinuities in resistivity that parallel the axis of the rotation data. Such discontinuities may be fault-controlled, but they might also represent variations in the crustal geothermal or magmatic regimes.

Furgerson (1982) constructed a composite of 1-D modeled data along a traverse roughly perpendicular to the Walker Lane belt that suggested the second inference mentioned above. However, the data were too widely dispersed to clearly map specific inferred faults or other linear discontinuities. In fact, if the conductive zones inferred from these data are deep, they may not be distinguishable from each other even with closely spaced MT soundings. Furgerson (1982) does not provide an analysis of the rotation variations versus frequency, but such an analysis could provide insight on the distance or depth of conductive zones from particular MT stations.

There are three soundings in the data reported by Furgerson (1982) that show strike directions misaligned from the west to northwest direction more commonly observed in his data. These anomalous soundings (21, 18 and 12, on fig. 4.3) suggest additional conductive zones that have rotated the electrical strike more northeastwardly. Based on the major strike indication at other stations, it is likely that the anomalous strikes reflect a superimposed influence of structures along the Walker Lane belt and structures that trend northeast across the Walker Lane Belt such as north- to northeast-striking tectonic zones described by Carr (1984). Furgerson (1982) noted that two of the anomalous soundings border the edges of the Timber Mountain Caldera, and features of magmatic origin as well as faults may thus contribute to the anomalies. The northeast-striking fault zones within and transverse to the Walker Lane Belt are presently more seismically active (Carr, 1984) than faults of other orientation, but, as also suggested by Carr (1984), this activity may be largely the result of the present stress field rather than more pronounced northeast-striking crustal weaknesses. The inference of a major conductive anisotropy roughly parallel to the Walker Lane belt suggests the potential of westerly to northwesterly crustal weakness which may be subject to seismic reactivation given a suitable reorientation of stress conditions.

The combined MT data presently available point to significant electrical inhomogeneity throughout the Nevada Test Site area. This characteristic is apparent in the 
sounding curves independent of the modeling. Although 1-D interpretations of such data may contain important distortions with regard to the resistivity distribution at depth, it may be instructive to examine a few of these interpretations in terms of regional resistivity structure. Such an examination must bear in mind that small-dimension features seen in the results from 1-D modeling may be artifacts of local conditions of shallow electrical structure as opposed to electrical structure at depth. Four deep electrical profiles traverse parts of the Walker Lane belt (fig. 4.5A). The composite 1-D interpretations of the data along these profiles are shown on figure 4.5(B). Three of the profiles are from data discussed above and are near or within parts of the Nevada Test Site, whereas one profile (d-d'; Lienert and Bennett, 1977) traverses an area near Walker Lake and Yerrington in western Nevada. A common feature among the four composite 1-D model sections is a deep low-resistivity zone (DLRZ) having resistivity typically in the range of 3 to $10 \mathrm{ohm}-\mathrm{m}$. The DLRZ is overlain by higher upper-crustal resistivity, which commonly has values in the range of 300 to $3,000 \mathrm{ohm}-\mathrm{m}$. There are variations in the depth to the DLRZ which occur across a range of horizontal dimensions, but the main characteristic is a DLRZ modeled at a depth between 10 and $30 \mathrm{~km}$ over a large region associated with the Amargosa Desert and the Jackass Flats area.

A deep crustal low-resistivity zone is also commonly modeled in other regions in the western United States (Stanley and others, 1977; Jiracek and others, 1983; Klein and Sneddon, 1987). There is as yet no completely satisfactory explanation for this lowresistivity zone, although the presence of a "wet" crust is often invoked as one probable explanation (Shankland and Ander, 1983). The DLRZ may be causally related to the transition from the brittle to ductile strain domain in the crust inasmuch as both electrical conductivity and ductile creep are enhanced by increased temperature and fluid composition (Wannamaker, 1980; Jiracek, 1983). Alternatively, the brittle-ductile transition may be a barrier to the upward migration of deep metamorphic fluids (Eaton, 1980, fig. 2b; Jiracek and others, 1983). Empirically, the depth of this DLRZ corresponds to the depth of the seismic zone in the Nevada Test Site region. Ninety percent of the earthquakes in the Nevada Test Site region occur at depths above 10 to $15 \mathrm{~km}$, and the deepest earthquakes are at a depth of about $30 \mathrm{~km}$ (Rogers and others, 1981, 1983). If resistivity and ductility are related, then inferred variations in the depth to the low-resistivity zone may indicate similar lateral variations in crustal strength which may cause stress differentials.

The thickness of the DLRZ cannot be determined from the available data. The MT sounding curves for the Yucca Mountain region typically extend to $0.003 \mathrm{~Hz}$ at the lower range of frequencies. Therefore, MT signal penetration of the DLRZ sufficient for a clear indication of the underlying resistivity would probably require observations to lower frequencies, to at least as low as $0.0003 \mathrm{~Hz}$. For the lowest frequency data available and a resistivity of $10 \mathrm{ohm}-\mathrm{m}, 1-\mathrm{D}$ modeling indicates that the thickness of the DLRZ is at least $10 \mathrm{~km}$ thick.

In the 1-D composite cross sections of figure 4.5 (B), variations in the depth to the DLRZ that occur across distances of less than about $20 \mathrm{~km}$ are defined by only one or two 


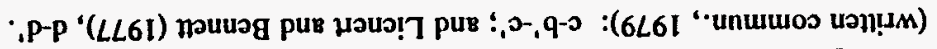

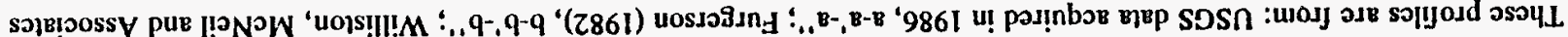

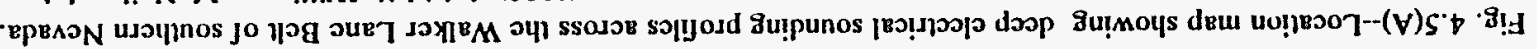
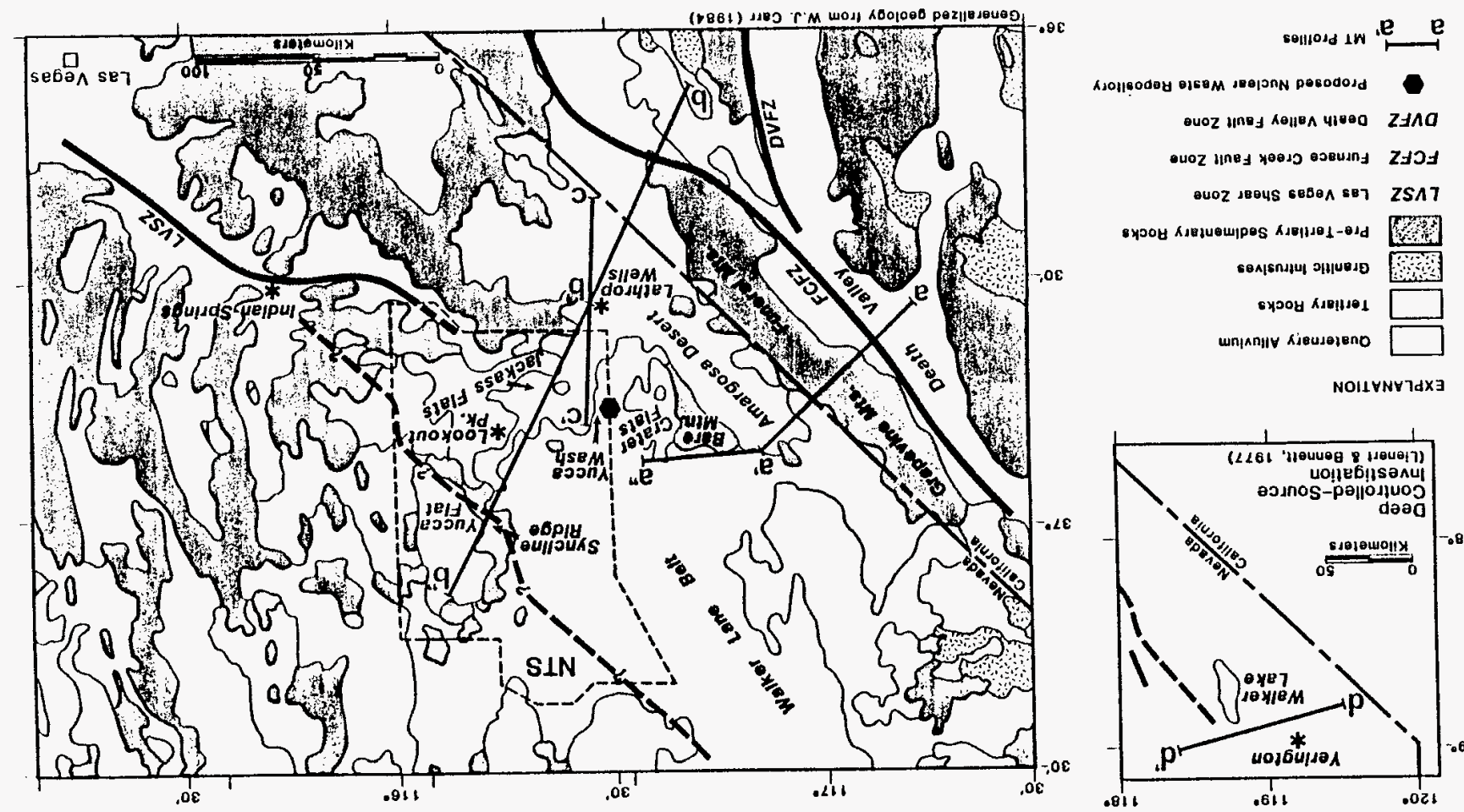

NoIเYNYาdX3

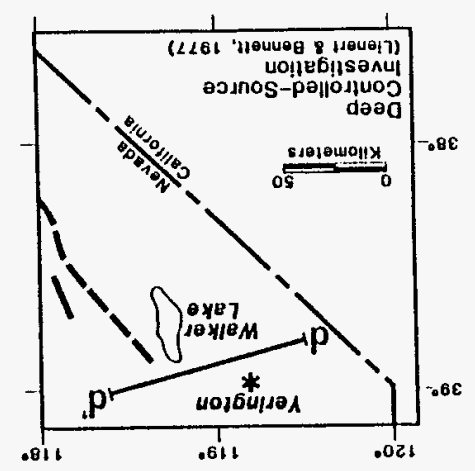




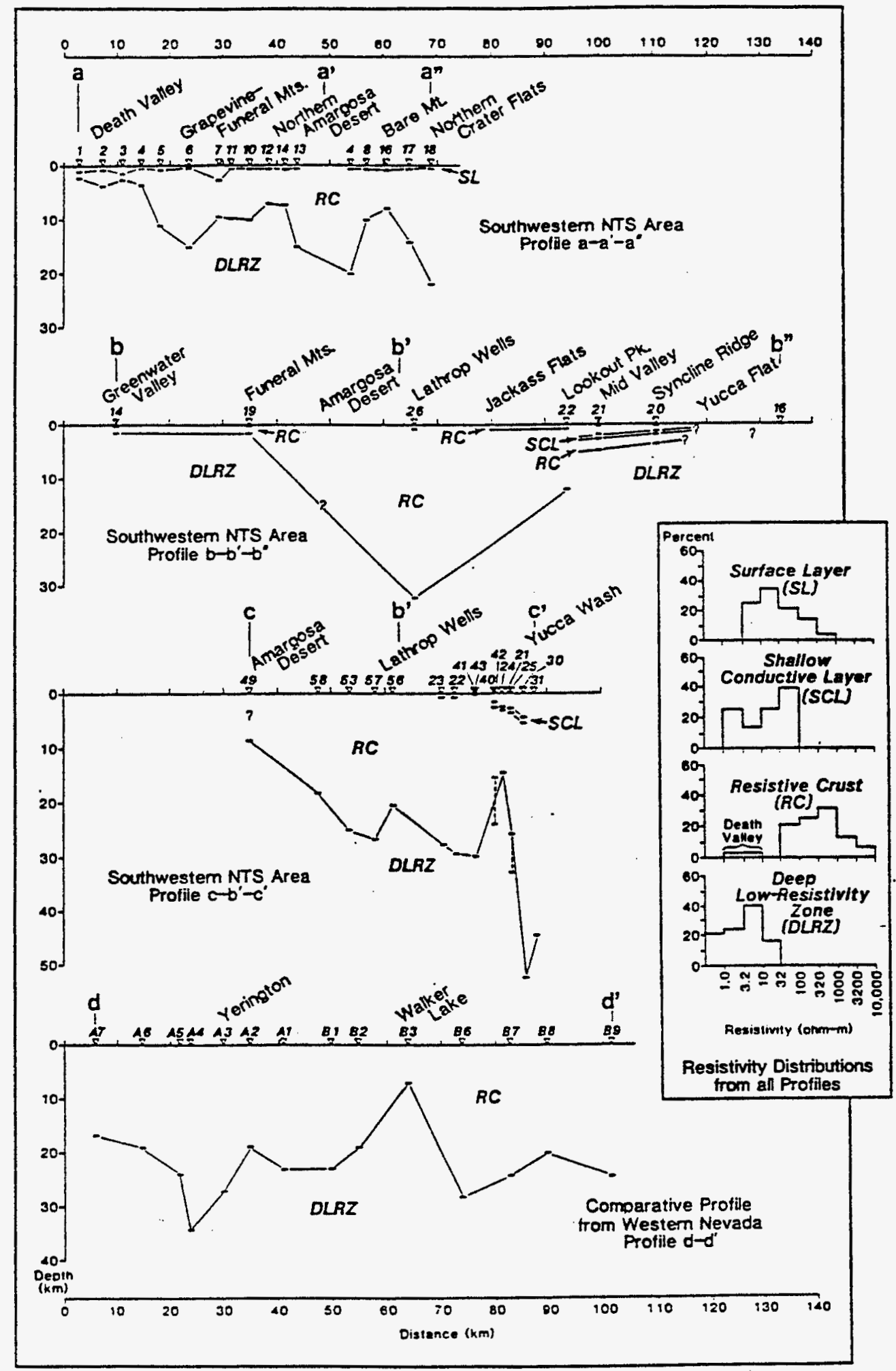

Fig. 4.5(B)-Comparison of composite 1-D models of the deep electrical soundings on profiles shown in fig. 4.5(A). Profiles a$a^{\prime}-a^{\prime \prime}, b-b^{\prime}-b^{\prime \prime}$ and $c-b^{\prime}-c^{\prime}$ are based on MT data in the vicinity of the Nevada Test Site (Williston, McNeil and Associates, written commun., 1979; Furgerson, 1982; and USGS data collected in 1986). Profile d-d' is based on deep controlled source soundings in the area of Walker Lake and Yerrington, Nevada (Leinert and Benneth, 1977). There is no vertical exaggeration in these composite interpretations. The resistivities associated with the various layers shown are indicated on the histogram. 
soundings and are highly uncertain. Such short-dimension structures will have to be verified by 2-D modeling. Regional changes in the depth to the DLRZ that occur with some consistency among several soundings across a distance of more than about $20 \mathrm{~km}$, however, may be considered representative of the actual resistivity structure.

One notable regional feature is the apparent decrease in depth of the DLRZ from the central Amargosa Desert area to the northern part of the Amargosa Desert. Typical depth to the DLRZ in the northern Amargosa desert and Beatty region (fig. 4.5B, profile a-a'-a") is 10 to $20 \mathrm{~km}$, compared to typical depths of 20 to $30 \mathrm{~km}$ in the central Amargosa Desert and Lathrop Wells area (fig. 4.5B, profiles b-b'-b" and c-b'-c'). Such a difference between areas may suggest a decrease in the crustal thermal gradient from north to south in the Amargosa Desert or a change in deep fracture and fault density. Processes that may be invoked to explain the conductivity anomaly include deep heat sources or deep circulating fluids. It is important to confirm this anomaly, as well as the possible smaller resistivity structures, by using 2-D modeling.

Another characteristic of note in the regional resistivity pattern is the shallow depth to low resistivity south or southwest and north or northeast of the Amargosa Desert and the area of Jackass Flats. To the south, low resistivity occurs at a depth of about 3 to $5 \mathrm{~km}$ in the Death Valley area (profile a-a'- a", fig. 4.5B) and in the Funeral Mountains and Greenwater areas (profile b-b'- b", fig. 4.5B). To the north, low resistivity occurs in the Syncline Ridge area at a depth of $5 \mathrm{~km}$ or less on profile $b-b^{\prime}-b^{\prime \prime}$. Although the anomaly in the Syncline Ridge area is shown on only two soundings on the illustrated profile, the anomaly is also present in the interpretations of D.R. Word and others (written commun., 1977) for 12 nearby soundings.

On figure 4.5 , the regions of shallow low resistivity are connected to suggest an upward warp of the DLRZ. This, however, may not be the actual case. Where low resistivity is found at anomalously shallow depth of less than $5 \mathrm{~km}$, it may represent a local condition of different nature from that causing the regional DLRZ at depths greater than 10 $\mathrm{km}$. The shallowest zones of low resistivity, in such areas as Death Valley or the Furnace Creek Fault Zone area, may represent isolated shallow conductors caused by anomalous concentrations of saline fluids, abnormally high temperatures, or strong rock alteration. Shallow melt zones cannot be ruled out but seem improbable without the presence of recent volcanism in these areas. The extremely low resistivity of $1 \mathrm{ohm}-\mathrm{m}$ or less in such zones would inhibit identification of a deeper high-resistivity layer located above a regional DLRZ.

The 1-D composite sections $c-b^{\prime}-c^{\prime}$ and $b-b^{\prime}-b^{\prime \prime}$ in figure 4.5 (B) also show relatively thin and shallow conductive layers above the DLRZ in the area of Syncline Ridge and Yucca Mountain. These shallow layers are distinct from the basal DLRZ at depths below 5 or $10 \mathrm{~km}$. These layers have a thickness of less than $1 \mathrm{~km}$ and are located at depths typically in the range of 2 to $4 \mathrm{~km}$. Such thin conductive zones may represent a lithologic or structural horizon such as an argillic bed (for example, Mississippian rocks of the Eleana Formation; Hoover and others, 1982c), an altered, zeolite-rich layer in volcanic rock, or a 
brecciated and altered low-angle fault zone. Interpretation of these shallow layers will require close coordination with local geological information, drill-hole data, and shallowpenetrating electrical surveys. The optimum approach is to attempt to trace the modeled low-resistivity zone to a point of shallow depth where drill-hole logs or surface mapping will allow a geologic correlation.

\section{MAGNETOTELLURIC PROFILE ACROSS SOUTHERN YUCCA MOUNTAIN}

The USGS magnetotelluric data acquired in 1986 include a series of soundings extending eastward from Bare Mountain, across Crater Flat and the southern part of Yucca Mountain, and into Jackass Flats. Seven of these soundings that traverse the southern part of Yucca Mountain area are shown (fig. 4.6). The model shown on figure 4.6 is one of series of models being investigated using forward modeling with a 2-D algorithm described by Swift (1971). The computed sounding curves have been shifted by constant values so that the model fits the observed data in the best least-squares sense. This shift is required to account for near-surface 3-D inhomogeneities. The model shown in figure 4.6 is not uniquely defined by the data. There are similarities among the various acceptable models generated for this area, however, and the similarities are assumed to represent the major resolvable features required by the data. The MT model (fig. 4.6) consists of four regions: (1) a surface layer of generally low resistivity (10 to $100 \mathrm{ohm}-\mathrm{m})$ extending to depths of 0.5 to $2 \mathrm{~km}$; (2) an upper crustal zone of variable thickness and resistivity that shows a significant increase in thickness west of Yucca Mountain; (3) a resistive crustal layer (500 ohm-m); and (4) a low-resistivity zone in the middle crust starting at about $16 \mathrm{~km}$ depth that forms the basal layer of the model. The low-resistivity surface layer represents unconsolidated sedimentary units, volcanic rocks, and weathered zones in the Paleozoic bedrock of Bare Mountain. For the surface layer, the present MT data resolve an average parameter of conductance, which is the integrated thickness divided by resistivity. Resolution of specific units in the surface layer is minimal, and its correspondence to drill hole data will be very general. For MT data with frequencies less than $20 \mathrm{~Hz}$, the modeled vertical distribution in this layer provides little geologic information, but integrated shallow horizontal variations within about 2 or $3 \mathrm{~km}$ of a sounding location can be quite well determined.

In the upper-crustal zone, the model identifies various electrical units ranging in value from 50 to $500 \mathrm{ohm}-\mathrm{m}$. This zone extends to variable depths of 4 to $12 \mathrm{~km}$, and it is consistently underlain by high resistivity which is indicative of the major part of the basement. The upper-crustal zone, however, may also include volumes of basement rocks where these units are fractured, wet, and altered. The $5-$ to $7-\mathrm{km}$ spacings and frequencies of the MT data shown are well-suited for investigating the depth interval from about 2 to 12 $\mathrm{km}$, and the upper-crustal zone is believed to be the zone of highest resolution for the present data. In this modeling, the resistivity values vary as decade multiples of $10,15,20$, 40 , and $70 \mathrm{ohm}-\mathrm{m}$, or roughly six intervals per decade. The horizontal interfaces are also established at about six intervals per decade in $\mathrm{km}$. The vertical-interface locations 


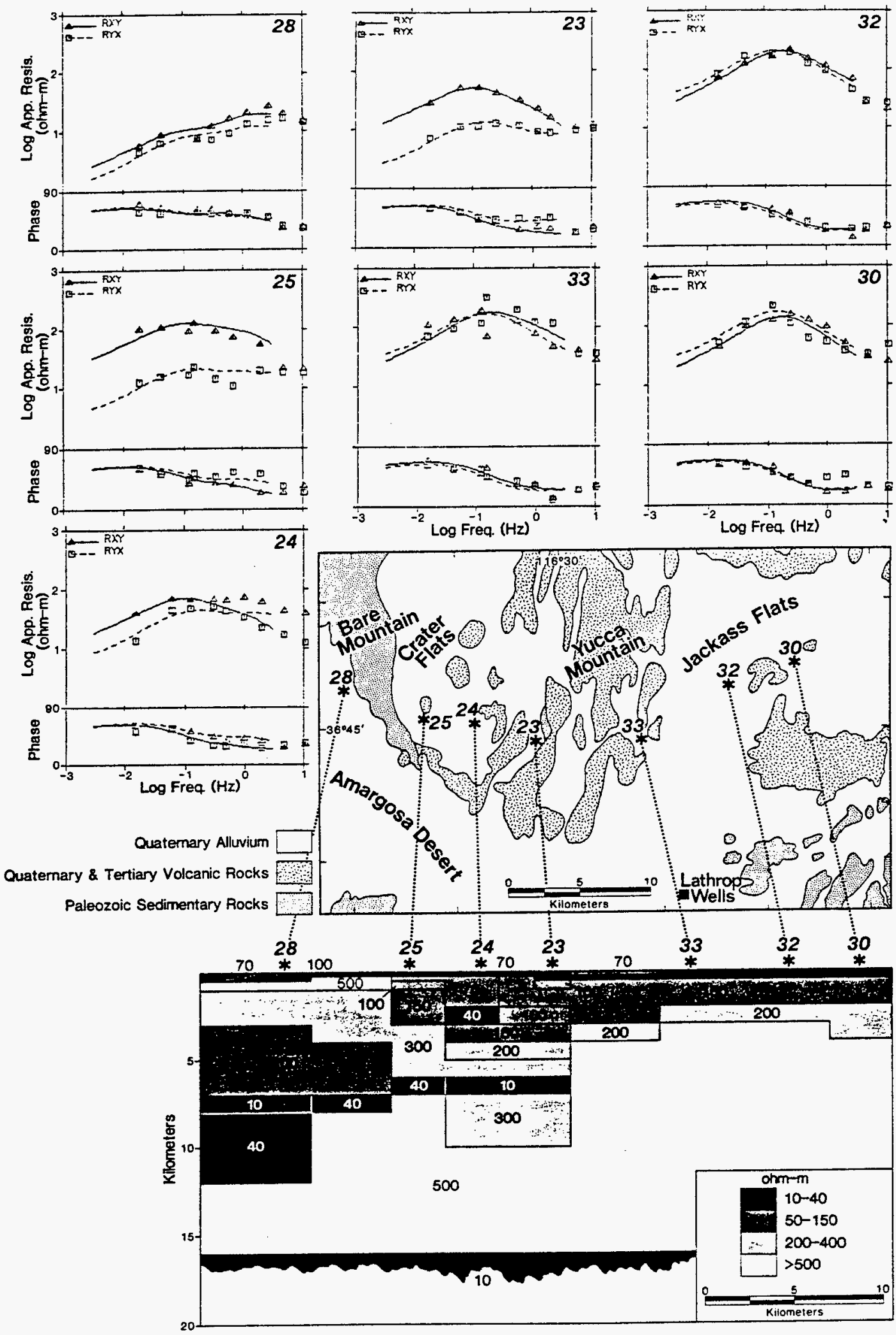

Fig. 4.6-Preliminary 2-D resistivity model across the southern part of the Yucca Mountain area based on USGS MT data acquired in 1986. The model was generated using the 2-D algorithm of Swift (1971). Observed sounding data are shown by discrete symbols (triangles and square boxes); computed response curves are shown by solid and dashed lines. Triangles and continuous lines respesent the E-parallel mode (TE); boxes and dashed lines represent the E-perpendicular mode (TM). 
are limited to one (at most two) between soundings. With these constraints, a well-fitted model may have relative uncertainties of about 15 to 20 percent in body resistivities and the location of interfaces which corresponds roughly to the uncertainty in the data.

To depths of about $4 \mathrm{~km}$, the more conductive bodies (50 to $150 \mathrm{ohm}-\mathrm{m}$ ) are interpreted to mark the distribution of volcanic rocks. Throughout this zone, the more resistive bodies (200 to $500 \mathrm{ohm}-\mathrm{m}$ ) are interpreted to represent Proterozoic and Paleozoic sedimentary rocks. Beneath Crater Flat and Bare Mountain, the upper-crustal zone extends to a depth of 8 or $13 \mathrm{~km}$ compared the 3 to $4 \mathrm{~km}$ depth range in Jackass Flats. The thickening of the this zone appears to occur abruptly at the west flank of Yucca Mountain. The thickening shown is constrained mainly by sounding 23 and to a lesser degree by soundings 33 and 24 .

Beneath Crater Flat and Bare Mountain, the model shows a discrete zone of low resistivities in the range of 10 to $40 \mathrm{ohm}-\mathrm{m}$ that occurs at about 6 to $8 \mathrm{~km}$ depth. The precise geometry and resistivity of this unit is uncertain. The major feature required by soundings $28,25,24$, and 23 , and represented by the modeled unit, is a low-resistivity unit in the range of 1 to $70 \mathrm{ohm}-\mathrm{m}$ within the depth range of 4 to $8 \mathrm{~km}$. The MT data would, for instance, be consistent with a thin zone having a thickness of a few hundred meters or less and a resistivity of $10 \mathrm{ohm}-\mathrm{m}$ or less. The presence of this relatively low-resistivity zone, allowing for the uncertainty mentioned, suggests several possibilities. The unit may represent an altered, volcanic, sedimentary or metasedimentary unit, or it may alternatively suggest a conductive breccia zone associated with a low-angle fault. For a resistivity of 10 ohm-m or less, a zone of about 3 percent partial melt would also be an allowable interpretation. The final preferred physical and geologic model for this unit will depend on conceptual models and (or) data independent of the present MT results.

The deeper extension of low resistivities ( $40 \mathrm{ohm}-\mathrm{m}$ to about $12 \mathrm{~km}$ depth) in the upper crust beneath sounding 28 on the margin of the Amargosa Desert near Bare Mountain is required to fit the data at this sounding. Other data will have to be used to confirm the western or southwestern extent of this unit inasmuch as the western limit of this model's extent would allow only that this zone be a linear feature having a width of about 5 $\mathrm{km}$. It can be noted that the apparent shallow depth of the deep conductor in the 1-D interpretations at Beatty and Lathrop Wells (fig. 4.5(B), soundings 8, 16, 17 on line a-a'-a", and sounding 56 on line $\left.c-b^{\prime}-c^{\prime}\right)$ may be artifacts due to erroneous $1-D$ interpretation of a shallower 2-D structure. A linear, conductive zone, such as might be associated with a deep, altered fault zone along the northeastern border of the Amargosa Desert, is also in accord with the regional strike interpreted by Furgerson (1982).

Below the upper crust, the model shows a more uniform and resistive basement of $500 \mathrm{ohm}-\mathrm{m}$ extending to depths of about $16 \mathrm{~km}$. The resistivity for this zone is in the low end of permissible resistivities; higher inferred resistivity of the order of $1000 \mathrm{ohm}-\mathrm{m}$ is possible. No electrical structure is identified in this zone. Inasmuch as resolution of MT data decreases exponentially with depth, however, detectable bodies would have to be large 
with respect to the depth range. In this regard, inhomogeneities of dimensions less than a few $\mathrm{km}$ are not ruled out, nor can they be reliably inferred.

The deep low-resistivity zone starting at a depth of about $16 \mathrm{~km}$ (fig. 4.6) is one the fundamental features of this 2-D model as well as of the 1-D solutions discussed with figure 4.5(B). Modeling in two or three dimensions normally results in a simpler representation of the geometry of deep conductors than 1-D modeling. Lateral inhomogeneities in the shallow regions of the crust, which can be included in 2-D modeling, have the effect of distorting 1-D interpretations (Berdichevsky and Dmitriev, 1977). There remains the 10 to 20 percent relative uncertainty, whereby the depth of the DLRZ may have relief on the order of a few kilometers or may occur as a vertically transitional zone rather than occurring at a discrete contact.

\section{CONCLUSIONS}

A number of magnetotelluric surveys have been performed in the Yucca Mountain area for the purpose of regional tectonic investigations as well as for investigations of more local extent. There has been little in the way of regional analysis of these data, although parts of the data have been utilized to infer electrical structure particular to the Syncline Ridge and Yucca Flat areas and to the Calico Hills area (Hoover, 1982b,c). In these areas, the MT data have been inferred to indicate the presence of intrusions, major fault zones, conductive argillic horizons, alteration, and possible anomalous temperatures.

Published reports on deep electrical structure from MT data in the NTS region have utilized 1-D modeling, which produces considerable uncertainty in the results. The uncertainty using 1-D modeling may amount to over 30 percent in depth and resistivity, and the uncertainty can be especially troublesome in indicating false relief on the deep lowresistivity zone. There are significant results available from MT data, however, which have little uncertainty. One such result is the determination of a regional electrical strike with an azimuth roughly coincident with the Walker Lane (mobile) belt (Furgerson, 1982). Another is that, in general, the Yucca Mountain area is characterized by a deep low-resistivity zone at depths of 10 to $30 \mathrm{~km}$. This low-resistivity zone is roughly correlative with the base of the seismic zone in this region. Finally, there is little doubt that the upper crust above about $5 \mathrm{~km}$ is electrically inhomogeneous, and more quantitative definition of this inhomogeneity using 2- and 3-D modeling should provide information on buried geologic structure and lithologic variation.

Generally, the 1-D models suggest that the deep low-resistivity zone occurs at somewhat greater depths in the region of Amargosa Desert and Jackass Flats compared to regions to the northeast and southeast. The deep low-resistivity zone may also be shallower in the western part of the Amargosa Desert than in the central region southwest of Lathrop Wells. There are shallow highly conductive regions at depths of about $5 \mathrm{~km}$ in the regions near the Furnace Creek and Death Valley Fault Zones, and in the region of Syncline Ridge. Locally, in the Yucca Mountain area, and near Syncline Ridge, the MT 
data suggest a thin conductive layer that may represent an electrically mappable lithologic unit or low-angle fault zone. The geologic correlation of this layer may differ in different areas.

Considerable potential exists for improved analysis of available data. Analytical smoothing of the sounding curves of the data will result in potentially better soundings curves for modeling. Two- or three-dimensional modeling seems imperative in future analysis. A large number of soundings from various surveys could be looked at coherently, rather than as separate data sets. The variable quality of these data can be accounted for in regional models by assigning weights to the data based on the estimated uncertainty for each sounding. A recommended alternative is to acquire new data with consistent precision.

A preliminary 2-D model across the southern part of Yucca Mountain (fig. 4.6) represents the type of research recommended for further efforts. This model was based on USGS data acquired in 1986. The model of figure 4.6 suggests a major low-resistivity contrast along the west flank of Yucca Mountain that shows lower resistivities under Crater Flat. The model also suggests an anomalously low-resistivity zone beneath Crater Flat and Bare Mountain at depths below $4 \mathrm{~km}$. The deepest low-resistivity zone in the Yucca Mountain region is at $16 \mathrm{~km}$ depth and shows no discernable relief compared to various 1-D models for the region which show considerable scatter in the depth to this deep lowresistivity zone.

Deep electrical structure inferred from MT data can be expected to provide constraints on several questions concerning crustal structure and composition and tectonic processes in the region of Yucca Mountain. Constraints will relate to such characteristics as hydrous fluid distribution, thermal variations, magmatic activity, deep high- and lowangle faults, and crustal fracture patterns. Final interpretations will require integration with coincident data from deep seismic profiles, teleseismic data, heat-flow and Curie isotherm determinations, and gravity measurements. 


\section{REFERENCES CITED}

Berdichevsky, M.N. and Dmitriev, V.I., 1976, Basic principles of interpretation of magnetotelluric sounding curves, in Geoelectric and Geothermal Studies: Budapest, KAPG Monograph: Academiai Kaido, p. 165-221.

Brace, W.F., 1971, Resistivity of saturated crustal rocks to $40 \mathrm{~km}$ based on laboratory measurement, in Heacock, J.G., ed., The structure and physical properties of the Earth's Crust: . Washington D.C., American Geophysical Union, Geophysical Monograph 14, p. 243-255.

Carr, W.J., 1984, Regional structural setting of Yucca Mountain, southwestern Nevada, and late Cenozoic rates of tectonic activity in part of the southwestern Great Basin, Nevada and California: U.S. Geological Survey Open-File Report 84-854, 109 p.

Carr, W.J., 1988, Volcano-tectonic setting of Yucca Mountain and Crater Flat, southwestern Nevada, in Carr, M.D., and Yount, J.C., eds., Geologic and hydrologic investigations of a potential nuclear waste disposal site at Yucca Mountain, southern Nevada: U.S. Geological Survey Bulletin 1790, p. 35-49.

Chapman, R.H., Healey, D.L. and Troxel, B.W., (compilers), 1971. Bouguer gravity map of California Death Valley Sheet: Sacramento, State of California Division of Mines and Geology, scale 1:250,000, 8 p. text.

Clarke, J., Gamble, T.D., Goubau, W.M., Koch, R.H. and Miracky, R.F., 1983, Remotereference magnetotellurics: equipment and procedures: Geophysical Prospecting, v. 31 , p. $149-170$.

deVoogd, Beatrice, Serpa, Laura, Brown, Larry, Hauser, Ernest, Kaufman, Sidney, Oliver, Jack, Troxel, B.W., Willemin, James and Wright, L.A., 1986, Death Valley bright spot: a midcrustal magma body in the southern Great Basin, California?: Geology, v. 14, no. 1, p. 64-67.

Eaton, G.P., 1980, Geophysical and geological characteristics of the crust of the Basin and Range province, in Studies in Geophysics - Continental Tectonics: Washington D.C., National Academy of Science, p. 96-113.

Frischknecht, F.C. and Raab, P.V., 1984, Time-domain electromagnetic soundings at the Nevada Test Site, Nevada: Geophysics, v. 49, no. 7, p. $981-992$.

Furgerson, R.B., 1982, Remote-reference magnetotelluric survey, Nevada Test Site and vicinity, Nevada and California, with an introduction by D.B. Hoover: U.S. Geological Survey Open-File Report 82-465, 156 p. 
GTE Sylvania Incorporated, 1975, ELF Communications-Seafarer Program, site survey final report, western regions, Book 5, Earth conductivity data: Washington D.C., Navy Publications and Printing Service, control no. 309-B005-003, Contract N00039-75-C0309, Report for Naval Electronics Systems Command, Spec. Communications Project Office, ELF Communications Division, (reprinted 10 Aug., 1976), 63 p., Plates.

Hoover, D.B., Chornack, M.P. and Broker, M.M., 1982, E-Field ratio telluric traverses near Fortymile Wash, Nevada Test Site, Nevada: U.S. Geological Survey Open-File Report 82-1042, 15 p.

Hoover, D.B., Chornack, M.P., Nervick, K.H. and Broker, M.M., 1982, Electrical Studies at the proposed Wahmonie and Calico Hills nuclear waste sites, Nevada Test Site, Nye Co., Nevada: U.S. Geological Survey Open-File Report 82-466, 91 p.

Hoover, D.B., Hanna, W.F., Anderson, L.A., Flanigan, V.J. and Pankratz, L.W., 1982, Geophysical Studies of the Syncline Ridge area Nevada Test Site, Nye County, Nevada: U.S. Geological Survey Open-File Report 82-145, 68 p.

Hyndman, R.D. and Klemperer, S.L., 1989, Lower-crustal porosity from electrical measurements and inferences about composition from seismic velocities: Geophysical Research Letters, v. 16, p. 255-258.

Hyndman, R.D. and Shearer, P.M., 1989, Water in the lower continental crust: modeling magnetotelluric and seismic reflection results: Geophysical Journal International, v.98, p.343-365.

Jiracek, G.R., Gustafson, E.P. and Mitchell, P.S., 1983, Magnetotelluric results opposing magma origin of crustal conductor in the Rio Grande rift: Tectonophysics, v. 94, p. 299-326.

Kariya, K.A. and Shankland, T.J., 1983, Electrical conductivity of dry lower crustal rocks: Geophysics, v. 48 , p. 52-61.

Keller, G.V. and Frischknecht, F.C., 1966, Electrical methods in geophysical prospecting: New York, Pergamon Press, 517 p.

Keller, G.V., 1982, Electrical properties of rocks and minerals, in Carmichael, R.S. (ed.), Handbook of Physical Properties of rocks, vol. 1, chapter 2, Boca Raton, Florida, CRC Press Inc., p. 217-293.

Klein, D.P. and Sneddon, R.A., 1987, Magnetotelluric data across west-central Arizona: U.S. Geological Survey Open-File Report 87-492, 18 p. 
Lebedev, E.B. and Khitarov, N.I., 1964, Dependence on the beginning of melting of granite and the electrical conductivity of its melt on high water vapor pressure: Geokhimihy, v. 3, p. 195-201.

Lienert, B.R. and Bennett, D.J., 1977, High electrical conductivities in the lower crust of the northwestern Basin and Range: an application of inverse theory to a controlledsource deep-magnetic-sounding experiment, in Heacock, J.G., ed., The Earth's crust, its nature and physical properties, Geophysical Monograph 20, Washington D.C., American Geophysical Union, p. 531-552.

Meredith, J.A. and Frischknecht, F.C., 1989, One- and two-dimensional inversion of magnetotelluric data across the Basin and Range - Colorado Plateau, Virgin Mountains area, NW Arizona and SW Nevada: U.S. Geological Survey Open-File Report 89-573, $40 \mathrm{p}$.

Olhoeft, G.R., 1981, Electrical properties of granite with implications for the lower crust: Journal Geophysical Research, v. 86, p. 931-936.

Plouff, Donald, 1965, Magnetotelluric soundings in the southwestern United States: U.S. Geological Survey Technical Letter Crustal Studies-35, May 21, DDC Catalog no. $463940,30 \mathrm{p}$.

Plouff, Donald, 1966, Magnetotelluric soundings in the southwestern United States: Geophysics, v. 31, p. 1145-1152.

Porath, H., 1971, A review of the evidence on low-resistivity layers in the Earth's crust, in Heacock, J.G., ed., 1971, The structure and physical properties of the Earth's crust, Geophysical Monograph 14. Washington D.C., American Geophysical Union, p. 127144.

Rogers, A.M., Harmsen, S.C., Carr, W.J. and Spence, W.J., 1983, Southern Great Basin seismological data report for 1981, and preliminary data analysis: U.S. Geological Survey Open-File Report 83-669, 240 p.

Shankland, T.J. and Ander, M.E., 1983, Electrical conductivity, temperatures, and fluids in the lower crust: Journal Geophysical Research, v. 88, p. 9475-9484.

Snyder, D.B. and Carr, W.J., 1984, Interpretation of gravity data in a complex volcano tectonic setting, southwestern Nevada: Journal Geophysical Research, v. 89, no. B12, p. $10,193-10,206$.

Stanley, W.D., Boehl, J.E., Bostick, F.X., Jr. and Smith, H.W., 1977, Geothermal significance of magnetotelluric sounding in the eastern Snake River Plain- Yellowstone region: Journal Geophysical Research, v. 82, p. 2501-2514. 
Stewart, J.H., 1980, Geology of Nevada: a discussion to accompany the geologic map of Nevada (U.S. Geological Survey): Reno, Nevada Bureau of Mines and Geology, Special Publication 4, $136 \mathrm{p}$.

Stewart, J.H. and Carlson, J.E., 1978, Geologic map of Nevada: U.S. Geological Survey State Map Series. Scale 1:500,000.

Swift, C.M.,Jr., 1971, Theoretical magnetotelluric and turam response from twodimensional inhomogeneities: Geophysics, v. 36, p. 38-52.

Thompson, G.A. and Burke, D.B., 1974, Regional geophysics of the Basin and Range Province: Annual Reviews Earth Planetary Science, v. 2, p. 213-238.

Vozoff, Keeva, 1972, The magnetotelluric method in the exploration of sedimentary basins: Geophysics, v. 37, p. 98-141.

Waff, H.S., 1974, Theoretical considerations of electrical conductivity in partially molten mantle and implications for geothermometry: Journal Geophysical Research v. 79, p. 4003-4010.

Waff, H.S. and Weill, D.F., 1975, Electrical conductivity of magmatic liquids: effects of temperature, oxygen fugacity and composition: Earth Planetary Science Letters, v. 28, p. $254-260$.

Wannamaker, P.E., Ward, S.H., Hohmann, G.W. and Sill, W.R., 1980, Magnetotelluric models of the Roosevelt Hot Springs Thermal area, Utah: Salt Lake City, University of Utah, Department of Geology-Geophysics, report DOE/ET/27002-8, for Department of Energy contract DE-AC07-79ET27002, $231 \mathrm{p}$.

Zablocki, C.J., 1979, Some reconnaissance-type electrical surveys of Timber Mountain caldera, Nye County, Nevada: U.S. Geological Survey Open-File Report 79-1695, 23 p. 


\title{
MAJOR RESULTS OF GEOPHYSICAL INVESTIGATIONS AT YUCCA MOUNTAIN AND VICINITY, SOUTHERN NEVADA
}

\section{CHAPTER 5: SEISMIC REFRACTION INVESTIGATIONS}

\author{
By Walter D. Mooney and Scott G. Schapper
}

\section{INTRODUCTION}

\begin{abstract}
Seismic investigations play an important role in the characterization of Yucca Mountain as a possible repository. Five detailed seismic refraction profiles collected between 1983 and 1985 in the vicinity of Yucca Mountain, Nye County, Nevada, the potential site of a repository for high-level nuclear waste (fig. 5.1), are described in this chapter. These profiles have been interpreted to define the upper crustal velocity structure near the proposed site. The potential repository resides within Cenozoic tuff comprising the northern part of Yucca Mountain, a relatively coherent block within a stratigraphically and structurally complex region. Cenozoic sedimentary and volcanic rocks in and around the mountain obscure the more complex pre-Tertiary geology. Obtaining geophysical information about subsurface structures is therefore crucial to the assessment of regional geologic stability and hydrologic patterns. When combined with geologic and other geophysical information, these five profiles provide a three-dimensional view of the structural setting in the vicinity of the site. As in other chapters in this compilation, the reader should note the time frame of the data collections described here. Additional data sets obtained after the scope of this report include refraction information derived from chemical explosions in nonproliferation tests, details from the regional Southern Great Basin seismic network, and information derived from the regional seismic reflection lines collected by the USGS in 1994.
\end{abstract}

\section{DATA AND ANALYSIS}

The first two refraction profiles, collected in 1983, were recorded in a north-south direction in Crater Flat (the Crater Flat profile) and in an east-west direction from northern Crater Flat to the Bullfrog Hills and Grapevine Mountains, west of Beatty, Nevada (Beatty profile; fig. 5.1). Interpretations of these two profiles were first supplied by Ackermann and others (1988). The next three profiles, acquired in 1985, were recorded in an east-west direction across Yucca Mountain, from the northern Amargosa Valley to Jackass Flats (Yucca Mountain profile); in a north-south direction along Fortymile Wash, located east of Yucca Mountain (Fortymile Wash profile); and in an east-west direction in the Amargosa Valley at the southern end of Yucca Mountain (Amargosa profile). These profiles traverse a complex geologic setting characteristic of the Walker Lane volcano-tectonic belt of the western Great Basin (W.J. Carr, 1984). The multiplicity of recorded seismic refraction profiles provides ties at crossing points, thereby yielding significantly more reliable interpretations of the more complex profiles. 


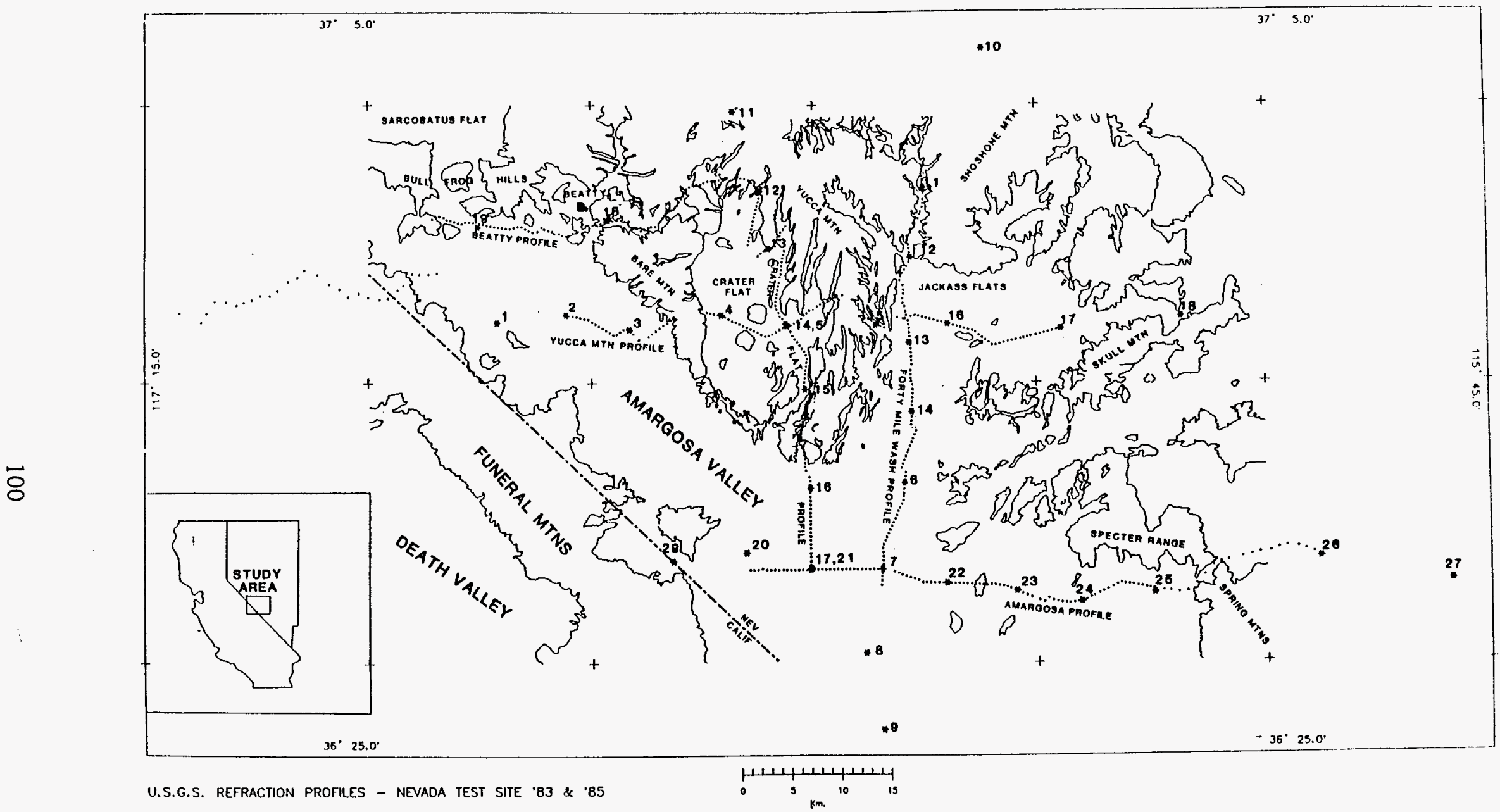

Figure 5.1. Map of the study area showing the locations of five seismic refraction profiles. East-ivest profiles are the Beatty, Yucca Mountain, and Amargosa profiles, while the north-south profiles are the Crater Flat and Fortymile Wash profiles. Dots represent approximate seismometer locations, and stars indicate approximate shot points. The approximate location of the potential repository is marked in the center of the figure by the solid rectangle on Yucca Mountain. 
The profiles averaged $45 \mathrm{~km}$ in length and were recorded with portable seismographs spaced at $300-\mathrm{m}$ intervals, with shot points at $5-$ to $8-\mathrm{km}$ intervals. Each shot consisted of approximately $900 \mathrm{~kg}$ of explosive placed in $50-\mathrm{m}$-deep drill holes. The data-acquisition parameters were designed to provide details of crustal structure to a depth at least as great as the maximum depth to pre-Tertiary rocks, estimated from gravity data (Snyder and Carr, 1984 ) to be as much as $4.0 \pm 1.0 \mathrm{~km}$ in Crater Flat. The principal facts (for example, shot point and recorder locations, etc.) and reduced-time plots of the data collected on these profiles were presented by Sutton (1984 and 1985).

In order to avoid uncertainties inherent to trial-and-error modeling of the data, these refraction profiles were recorded with field parameters satisfying the requirements of a method for the direct inversion of the data (Ackermann and others, 1982). The primary requirements for the inversion method include close spatial sampling and multiple shot points along the profile. The seismic refraction data from the region of the potential nuclear waste site easily exceed the minimum requirements of this method. Seismic low-velocity zones are not derived from this inversion method; if such zones are evident from amplitude analysis of the data, they are incorporated into the solution by forward modeling subsequent to the data inversion.

\section{RESULTS}

The modeling of seismic refraction data yields a seismic velocity section consisting of discrete velocity layers in which velocities may vary laterally. Geologic interpretation of these models is somewhat subjective without additional information since velocity boundaries need not conform with geologic horizons. Fortunately, a substantial amount of geologic and complementary geophysical information is available for the Nevada Test Site region. An isostatic residual gravity map (fig. 5.2) of the area (U.S. Geological Survey, 1984) reveals upper-crustal gravity features used to augment interpretation of the refraction profiles.

\section{Yucca Mountain Profile}

The velocity model derived from this profile is presented (fig. 5.3) with and without vertical exaggeration. It trends east-west across Bare Mountain, Crater Flat, Yucca Mountain (just south of the potential repository site), and Jackass Flats (fig. 5.1). Although it transects complex geology, it was possible to interpret this profile reliably by using constraints provided by changes in seismic velocity, the intersecting north-south Crater Flat and Fortymile Wash profiles, G12 isostatic gravity data (fig. 5.2), and geologic data provided by the five wells proximal to this profile.

Drill holes USW VH-2 (1219 m total depth; Carr and Parrish, 1985), USW VH-1 (762 $\mathrm{m}$ total depth; W.J. Carr, 1982), USW G-3 (1533 m total depth; Scott and Castellanos, 1984), UE-25 p\#1 (1807 m total depth; M.D. Carr, and others, 1986), and J-13 (1063 m total depth; Thordarson, 1983) are located within $2 \mathrm{~km}$ of the profile and project along geologic strike to the locations shown (fig. 5.3). Sonic log data were available for drill holes USW VH-1, USW G-3, and UE-25 p\#1; as noted in a previous refraction study at Yucca Mountain (Pankratz, 


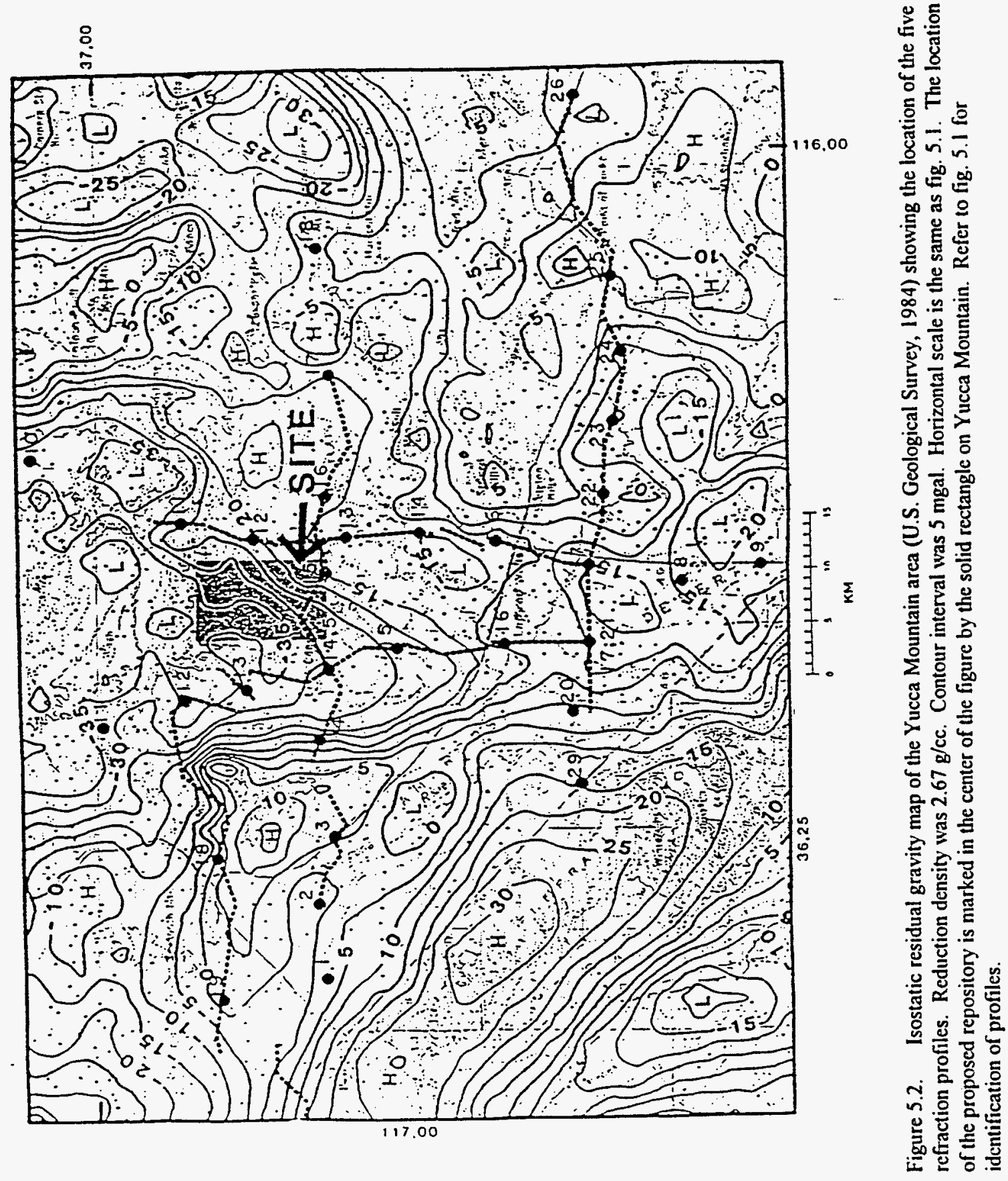



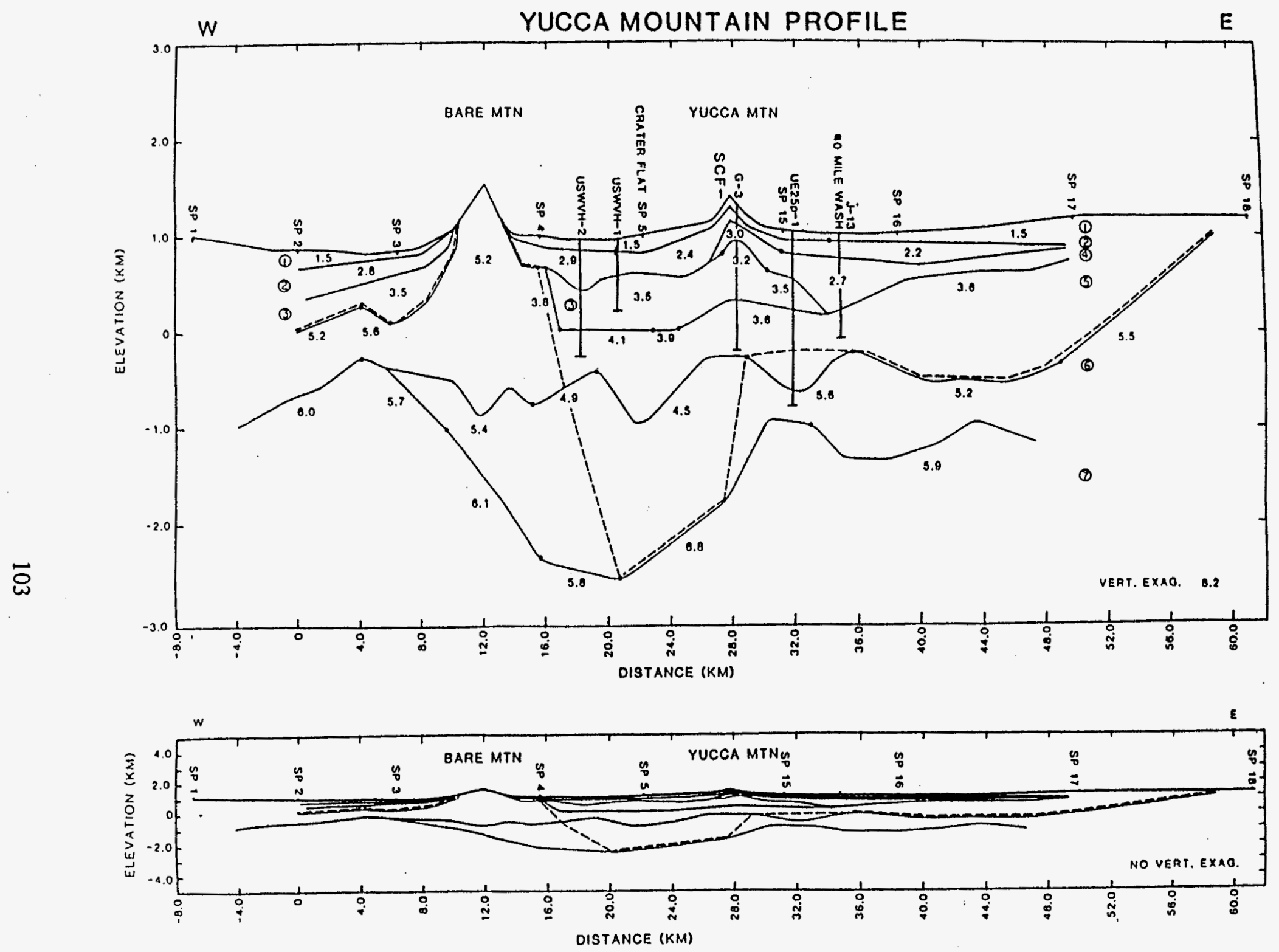

Figure 5.3. Crustal velocity section along the Yucca Mountain Profile. Seismic velocities are indicated in $\mathrm{km} / \mathrm{s}$, with dots representing lateral velocity changes. The inferred pre-Tertiary surface is shown by the dashed line, and layer numbers are circled. Drill holes (USW

$\mathrm{VH}-2$, USW VH-1, USW G-3, UE-25p\#1) and well (J-13) locations and points of intersection with other profiles are labeled. SCF indicates the approximate location of the Solitario Canyon fault. SP indicates approximate shotpoint locations. 
1982), however, the logs did not prove useful in correlation with refraction velocities. Within the Tertiary volcanic section, the sonic logs reflect the intraformational-scale seismic heterogeneities associated with lava flows, zones of fracturing, and differences in cementation and degree of welding within the tuffs. Undoubtedly, these heterogeneities occur laterally as well, causing the longer-wavelength refraction phases, which average these velocity effects, to reveal different velocities than those seen in boreholes. This velocity mismatch is also apparent within the pre-Tertiary section, where fracturing and differential cementation are the principal heterogeneities. Geologic data from these holes were instrumental in locating the pre-Tertiary contact, simply in terms of the depth to the contact if it was reached or how much Tertiary section could be expected below the hole.

The Yucca Mountain velocity section consists of seven seismic horizons, with the inferred pre-Tertiary surface (dashed line, fig. 5.3) cutting across one of these layers as dictated by the geologic, well, and gravity data, and by lateral changes in seismic velocity (fig. 5.3). Where they are exposed at the surface on Bare Mountain, the pre-Tertiary rocks (consisting of Upper Precambrian and Paleozoic clastic and carbonate rocks, metamorphosed between lower-greenschist and amphibolite facies) attain a seismic velocity on the order of 5.0 $\mathrm{km} / \mathrm{s}$, thus providing an approximate minimum velocity for the identification of pre-Tertiary bedrock on the sections.

At the west end of the section beneath the Amargosa Valley, pre-Tertiary rocks are represented by layer 5 which has velocities consistently greater than $5.0 \mathrm{~km} / \mathrm{s}$ up to and including Bare Mountain. On the east side of Bare Mountain, the pre-Tertiary surface follows layer 5 down about $300 \mathrm{~m}$ beneath Crater Flat, where it flattens, probably representing the top of a pre-Tertiary block that was faulted down from Bare Mountain. Near the east end of this "bench" (located beneath shot point 4, fig. 5.3), the velocity of layer 5 drops to $3.8 \mathrm{~km} / \mathrm{s}$. This velocity is too low to represent pre-Tertiary rocks; it is more likely that this represents the Tertiary volcanic fill of Crater Flat; along with some alluvium and Paleozoic slide-block debris as encountered in USW VH-2 (Carr and Parrish, 1985). The steep gravity gradient on the east side of Bare Mountain (coincident with shot point 4, fig. 5.2) suggests that the Crater Flat pre-Tertiary depression deepens rapidly here (Snyder and Carr, 1982). Thus, in our interpretation, the pre-Tertiary surface continues down at a steep angle to the top of layer 7 . The sub- $5.0 \mathrm{~km} / \mathrm{s}$ velocities of layer 6 within Crater Flat are too low for Paleozoic rocks at these depths, so we interpret this layer as comprising the deeper portion of the volcanic section filling Crater Flat. Extending the pre-Tertiary surface to the west-dipping top of layer 7 at a depth of about $3.5 \mathrm{~km}$ agrees with the gravity model of Snyder and Carr (1984). The unusually high velocity of this portion of layer $7(6.8 \mathrm{~km} / \mathrm{s})$ can be explained by the presence of massive Silurian dolomites beneath Crater Flat, as suggested by M.D. Carr and others (1986).

Beneath Yucca Mountain, layer 6 increases in velocity from $4.5 \mathrm{~km} / \mathrm{s}$ to $5.6 \mathrm{~km} / \mathrm{s}$, indicating that the eastem boundary of the Crater Flat depression transects layer 6 , with the pre-Tertiary surface emerging as the top of layer 6 . However, drill hole UE-25 p\#1 penetrated the Silurian Lone Mountain dolomite at a depth of $1244 \mathrm{~m}$ (M.D. Carr and others, 1986), which is within layer 5 where the velocity is $3.6 \mathrm{~km} / \mathrm{s}$. A velocity this low for dolomite 
can be explained by the observation that UE-25 p\#1 was drilled in a structural block (as delineated by surface geology, the eastern block of Yucca Mountain) that is highly fractured (M.D. Carr and others, 1986; U.S. Geological Survey, 1984). Cores recovered from UE-25 p\#1 show that the upper $425 \mathrm{~m}$ of dolomite is vuggy and strongly to intensely brecciated (M.D. Carr and others, 1986), probably resulting in no appreciable velocity contrast at the lithologic boundary. This zone of faulting and brecciation is reflected in the velocity section by the noticeable pull-down in the top of layer 6 . The refraction phase from layer 6 near UE$25 \mathrm{p} \# 1$ must be emanating from deeper within the Paleozoic rocks. In fact, the top of layer 6 intersects UE-25 p\#1 at the top of the underlying Silurian Roberts Mountain dolomite formation which is much less brecciated. The interpretation of a relatively high-standing preTertiary surface just east of Yucca Mountain (as shown by the dashed line, fig. 5.3) agrees with the gravity model of Snyder and Carr $(1982,1984)$, but their model is in better agreement with the pre-Tertiary contact in UE-25 p\#1. With a velocity of $5.6 \mathrm{~km} / \mathrm{s}$, the lessbrecciated dolomite in this structure is seismically slower than the dolomites hypothesized to form the base of the Crater Flat depression on this profile. This is related to burial depth and possibly the degree of fracturing. Layer 6 forms the east flank of this high and represents the pre-Tertiary surface for the remainder of the section with velocities exceeding $5.0 \mathrm{~km} / \mathrm{s}$. The maximum depth of inferred pre-Tertiary rocks beneath Jackass Flats is about $1.6 \mathrm{~km}$. Although the data are unreversed east of shot point 17 , the pre-Tertiary surface is shown to rise eastward toward the end of the profile in accordance with an isostatic gravity high (fig. 5.2) between shot points 17 and 18 and exposed pre-Tertiary rocks in the vicinity of Yucca Flat.

The seismic layers within the Tertiary volcanic section, for the most part, do not conform with the lithologic boundaries encountered in the drill holes. Again, this is probably due to the averaging effects of refraction wavelengths on smaller-scale distortions of lithologic boundaries due to faulting and other aforementioned lateral seismic heterogeneities. Beneath Yucca Mountain, layers 1 through 4 appear to mimic the topography, suggesting that seismic velocities in the shallow layers are related to lithostatic pressure. The top and bottom of layer 3 are coincident with the boundaries of the Crater Flat Tuff in USW G-3 and UE-25 p\#1, however, indicating that in this particular interval, there is a significant velocity contrast at the top and bottom boundaries of this formation. The pinch-out of layer 4 beneath western Yucca Mountain may be related to the west-dipping Solitario Canyon Fault (SCF, fig. 5.3), where stratigraphically younger rocks on the west are dropped against older rocks to the east, thus creating a lateral velocity contrast across the fault. The pinch-out of layer 3 between UE- 25 $\mathrm{p} \# 1$ and $J-13$ is likely associated with some east-dipping normal faults mapped at the surface (U.S. Geological Survey, 1984), but the pinch-out occurs within the tuffs of the Crater Flat Group, as dictated by well control, so it remains unclear as to what this surface may represent.

The Yucca Mountain profile yields the most pertinent information regarding the structural setting of Yucca Mountain. The non-exaggerated velocity section (fig. 5.3) shows the true geometry of the seismic layers and the inferred pre-Tertiary contact. Yucca Mountain is an eastward-tilted Tertiary volcanic plateau situated above the eastern flank of the westward-deepening Crater Flat pre-Tertiary depression. The pre-Tertiary surface rises to a relative high of $1.25 \mathrm{~km}$ depth beneath the eastern flank of Yucca Mountain and Fortymile 
Wash at the profile latitude, then drops more gradually into the Jackass Flats depression. The presence of carbonate clasts within the volcanic units atop the pre-Tertiary high at Yucca Mountain (M.D. Carr and others, 1986) indicates that this structure pre-dates the deformation that resulted in Yucca Mountain as a topographic high.

\section{Crater Flat Profile}

The velocity section for the north-south profile through Crater Flat (fig. 5.1) is shown (fig. 5.4) with USW VH-1, located $2 \mathrm{~km}$ west of this profile, indicated on the figure. The inferred pre-Tertiary surface is indicated by solid squares. The Crater Flat velocity section consists of six seismic layers; the first four are nearly horizontal layers of volcanic rocks. Layer 5 , with a seismic velocity of 4.7 to $4.8 \mathrm{~km} / \mathrm{s}$, begins beneath shot point 12 at a depth of approximately $2.0 \mathrm{~km}$ and continues to a maximum depth of about $3.2 \mathrm{~km}$ beneath shot point 14. The pre-Tertiary surface may occur within this layer; we believe, however, that confining pressures at depths of 2.0 to $3.2 \mathrm{~km}$ should be sufficient to close most cracks and pores and raise velocities of a hypothetical pre-Tertiary surface in this layer to well above $5.0 \mathrm{~km} / \mathrm{s}$. Thus, we interpret this layer as representing the deeper portion of the volcanic section filling the Crater Flat depression. The pre-Tertiary rock surface is represented by the basal $(5.7$ to $6.1 \mathrm{~km} / \mathrm{s}$ ) layer 6 , thus tying with the Yucca Mountain profile beneath shot point 14 . Layer 7 on the Yucca Mountain profile has a velocity of $6.8 \mathrm{~km} / \mathrm{s}$ where it ties with layer 6 of the Crater Flat profile at $6.1 \mathrm{~km} / \mathrm{s}$. This apparent seismic anisotropy is probably due to refracted phases traveling faster along the approximately east-west subsurface strike of Paleozoic dolomites in Crater Flat (M.D. Carr, and others, 1986) than they do in the north-south direction, which is more perpendicular to the bedding planes.

At the southern boundary of Crater Flat, we interpret the pre-Tertiary surface to rise, transect layer 5 , and emerge as the top of layer 5 beneath southern Yucca Mountain. This rise occurs where the velocity within layer 5 increases from 4.8 to $5.4 \mathrm{~km} / \mathrm{s}$ At $5.4 \mathrm{~km} / \mathrm{s}$, the preTertiary velocity is less than that beneath Crater Flat $(5.7$ to $6.1 \mathrm{~km} / \mathrm{s})$ perhaps because of lower lithostatic load on the pre-Tertiary rocks below southern Yucca Mountain. The interpretation of a higher-standing pre-Tertiary surface below southern Yucca Mountain agrees remarkably well with the isostatic gravity data (fig. 5.2) and the gravity model of Snyder and Carr $(1982,1984)$.

\section{Beatty Profile}

This east-west profile extends westward from northern Crater Flat, past the town of Beatty and the Bullfrog Hills, to Death Valley (fig. 5.1). It should be noted that the profile is unreversed west of shot point 19, so the velocity model (fig. 5.5) is non-unique in this region. For example, the extension of the $4.8 / 5.7 \mathrm{~km} / \mathrm{s}$ seismic horizon beneath the Grapevine Mountains (dashed line) was simply extrapolated from shot point 19 to Death Valley. A U.S. Borax drill hole is coincident with the profile and bottomed at $323 \mathrm{~m}$ in rhyodacite lava within the Tertiary Crater Flat Tuff. Our interpretation of the pre-Tertiary surface is indicated by the solid squares (fig. 5.5).

Paleozoic rocks occur near the surface west of shotpoint 18 , where the seismic velocity in the surface layer is $4.8 \mathrm{~km} / \mathrm{s}$. This suggests that these rocks are somewhat more 

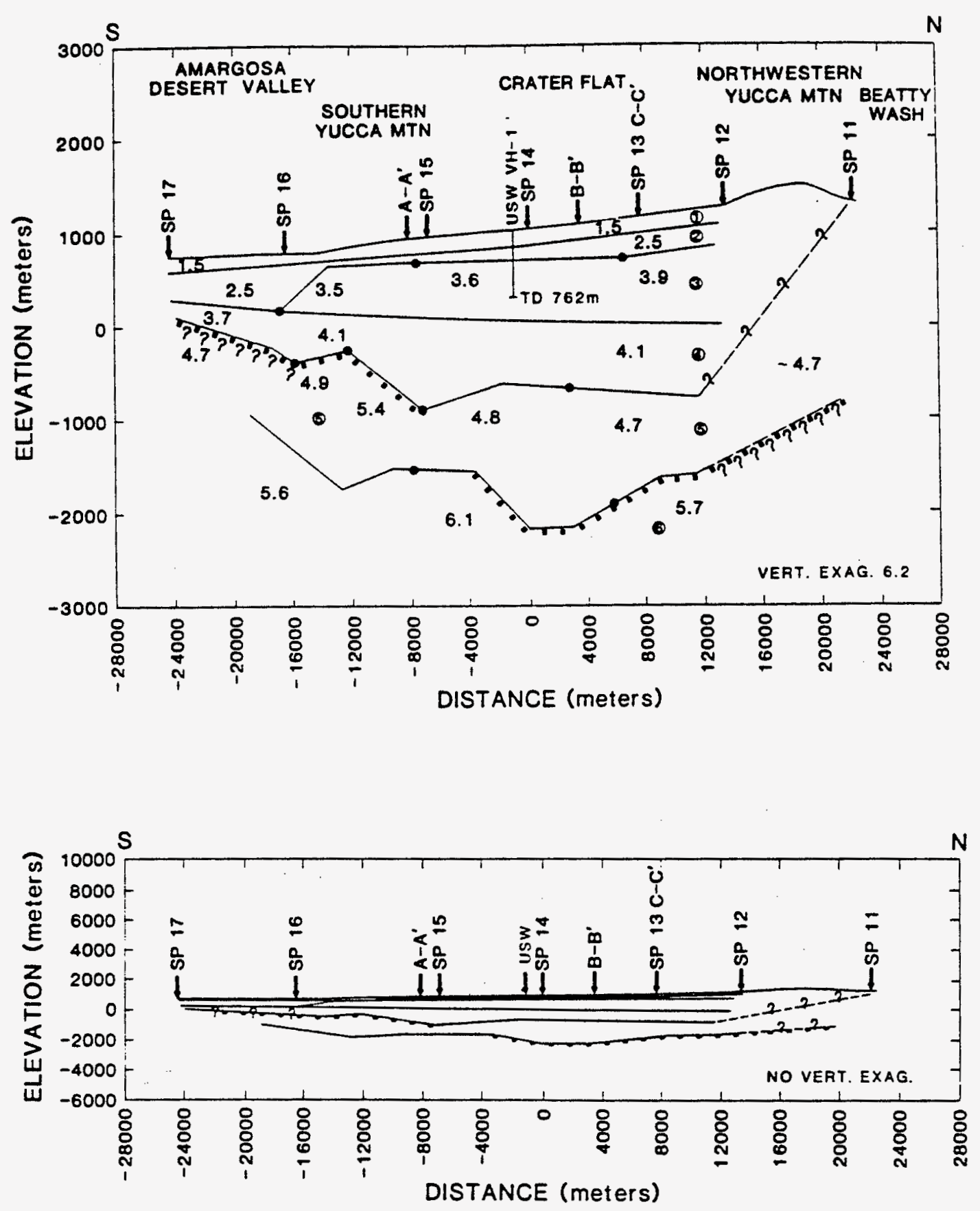

Figure 5.4. Crustal velocity section along the Crater Flat Profile (Ackermann and others, 1988). Seismic velocities are indicated in $\mathrm{km} / \mathrm{s}$. The inferred pre-Tertiary surface is shown by the solid squares, and layer numbers are circled. Uncertainties in the location of the pre-Tertiary surface are indicated by the shaded region. Drill hole USW VH-1 location is labeled. SP indicates approximate shotpoint locations. 

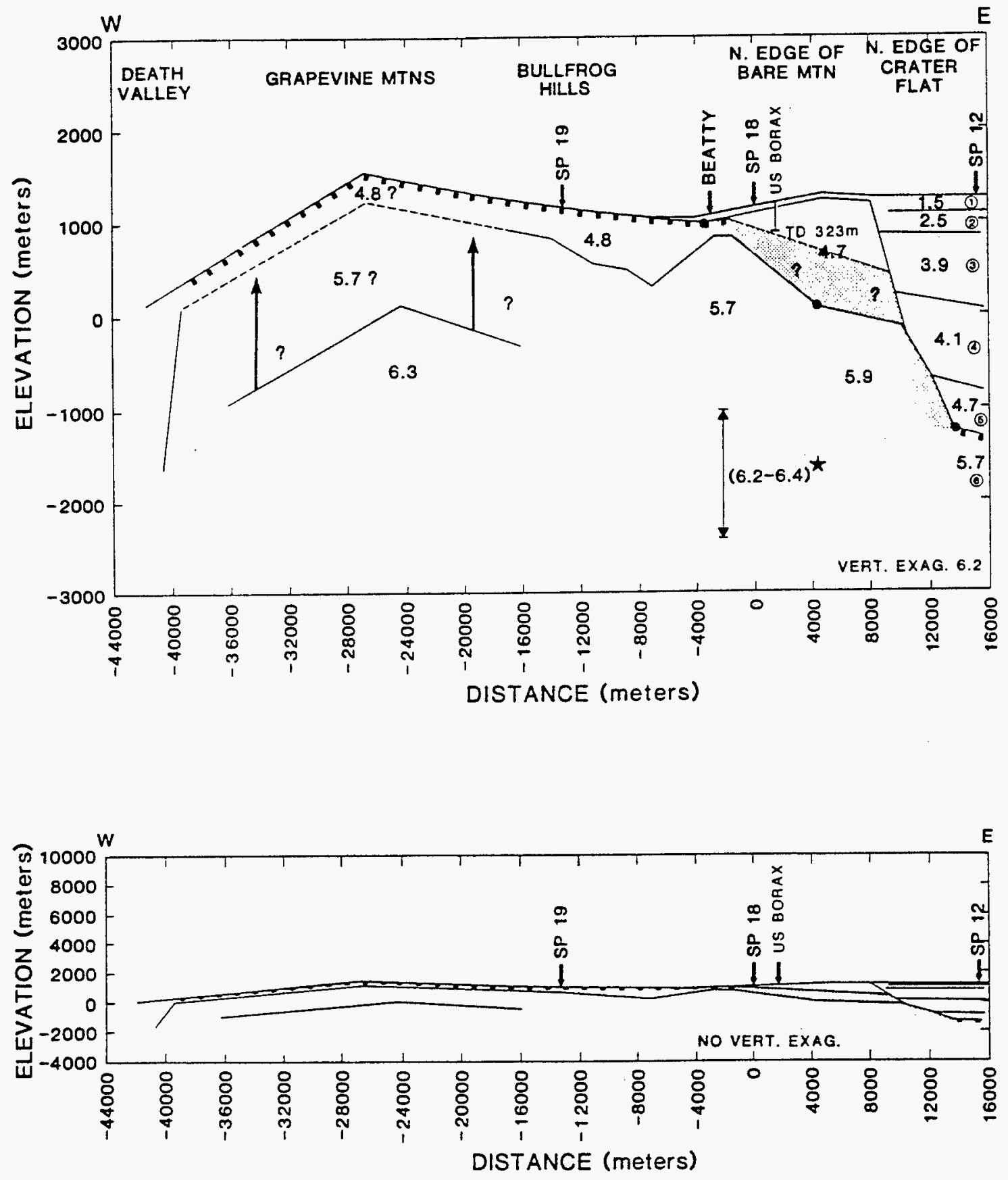

Figure 5.5. Crustal velocity section along the Beatty Profile (Ackermann and others, 1988). Scismic velocities are indicated in $\mathrm{km} / \mathrm{s}$. The inferred pre-Tertiary surface is shown by the solid squares, and layer numbers are circled. Uncertainties in the location of the pre-Tertiary surface are indicated by the shaded regions. U.S. Borax drill hole location is labeled. Profile intersects the Crater Flat profile at SP 12. The possible detachment fault at the $5.7 / 6.3 \mathrm{~km} / \mathrm{s}$ boundary is based on geologic mapping (Monsen, 1983; Giarmita and others, 1983) and seismic refraction and gravity data (Ackermann and others, 1988). Uncertainties in this boundary are indicated by the queried arrows. The location of the 6.2-6.4 km/s layer of Hoffman and Mooney (1983) is also indicated. SP indicates approximate shotpoint locations. 
fractured than their counterparts on Bare Mountain. It should be kept in mind, however, that no seismographs were deployed on Bare Mountain for the Beatty profile, so the velocity of $5.2 \mathrm{~km} / \mathrm{s}$ seen in that region on the Yucca Mountain profile represents raypaths through Bare Mountain at some depth. These fractures are essentially closed or much less abundant at depths greater than $400 \mathrm{~m}$ where velocities reach $5.7 \mathrm{~km} / \mathrm{s}$ (fig. 5.5 ).

East of shotpoint 18, the profile runs along the northern flank of Bare Mountain, entirely within Tertiary tuffs but mostly parallel to a major north-dipping normal fault that drops the tuffs down along the northern flank of Bare Mountain (fig. 5.1). This fault represents the pre-Tertiary contact. Projection of the northward dip of the fault at the north edge of Bare Mountain suggests that the pre-Tertiary surface occurs within the $4.7 \mathrm{~km} / \mathrm{s}$ layer. Our interpretation (indicated by the queried shaded region in fig. 5.5) assumes the presence of fractured pre-Tertiary rocks with velocities close to $4.7 \mathrm{~km} / \mathrm{s}$ beneath welded tuffs, with fractures closing at depths where the velocity increases to $5.7 \mathrm{~km} / \mathrm{s}$.

Beneath Crater Flat, horizontal layers 1 through 4 show increases in velocity with depth in the thick sequence of Tertiary volcanic rocks. With a velocity of 4.7 to $4.8 \mathrm{~km} / \mathrm{s}$, layer 5 begins at a depth of $1.8 \mathrm{~km}$ at the northeastern edge of Bare Mountain and ties with the Crater Flat profile at about $2.0 \mathrm{~km}$ beneath shot point 12. Again, on the basis of confining pressure and horizon-tying with the Crater Flat profile, we interpret layer 5 beneath Crater Flat as the deeper portion of the volcanic section filling the Crater Flat depression and the basal $5.7 \mathrm{~km} / \mathrm{s}$ layer as comprising the pre-Tertiary surface (shown by solid squares, fig. 5.5 ).

The portion of the Beatty profile between Death Valley and the Bullfrog Hills is unreversed, and layer velocities and depths are therefore poorly constrained. Despite this, an interesting geologic observation can be made. A layer with an approximate velocity of 6.3 $\mathrm{km} / \mathrm{s}$ is shown beneath the Grapevine Mountains. The top of this layer is hypothesized (Ackermann and others, 1988) to be the northward extension of the Boundary Canyon detachment fault (Giarmita and others, 1983). The possible continuation of this horizon to the northeast beneath the Bullfrog Hills could not be determined for lack of additional shot points. The data permit the $6.3 \mathrm{~km} / \mathrm{s}$ layer to be moved up beneath the Grapevine Mountains by as much as $1.0 \mathrm{~km}$, as indicated by the two queried arrows (fig. 5.5). A shallower depth, however, would require a significant downward displacement of the $6.3 \mathrm{~km} / \mathrm{s}$ layer east of the Bullfrog Hills since Hoffman and Mooney (1983) also identified a $6.2-6.4 \mathrm{~km} / \mathrm{s}$ layer at 1.0 to $2.4 \mathrm{~km}$ below sea level beneath Beatty (indicated by the bracket, fig. 5.5). Correlation of this layer with the $6.3 \mathrm{~km} / \mathrm{s}$ layer is supported by a gravity model constructed by Ackermann and others (1988):

\section{Fortymile Wash Profile}

The velocity section for the north-south profile along Fortymile Wash, just east of Yucca Mountain (fig. 5.1), consists of seven seismic layers (fig. 5.6). Well J-13 is coincident with this profile at its intersection with the Yucca Mountain profile. The inferred pre-Tertiary surface is indicated by the dashed line, which conforms with layer 6 for the length of the section. Our interpretation is based on the observations that (1) the top of layer 6 represents a boundary separating sub- $4.0 \mathrm{~km} / \mathrm{s}$ material from the greater than $5.0 \mathrm{~km} / \mathrm{s}$ material below, 

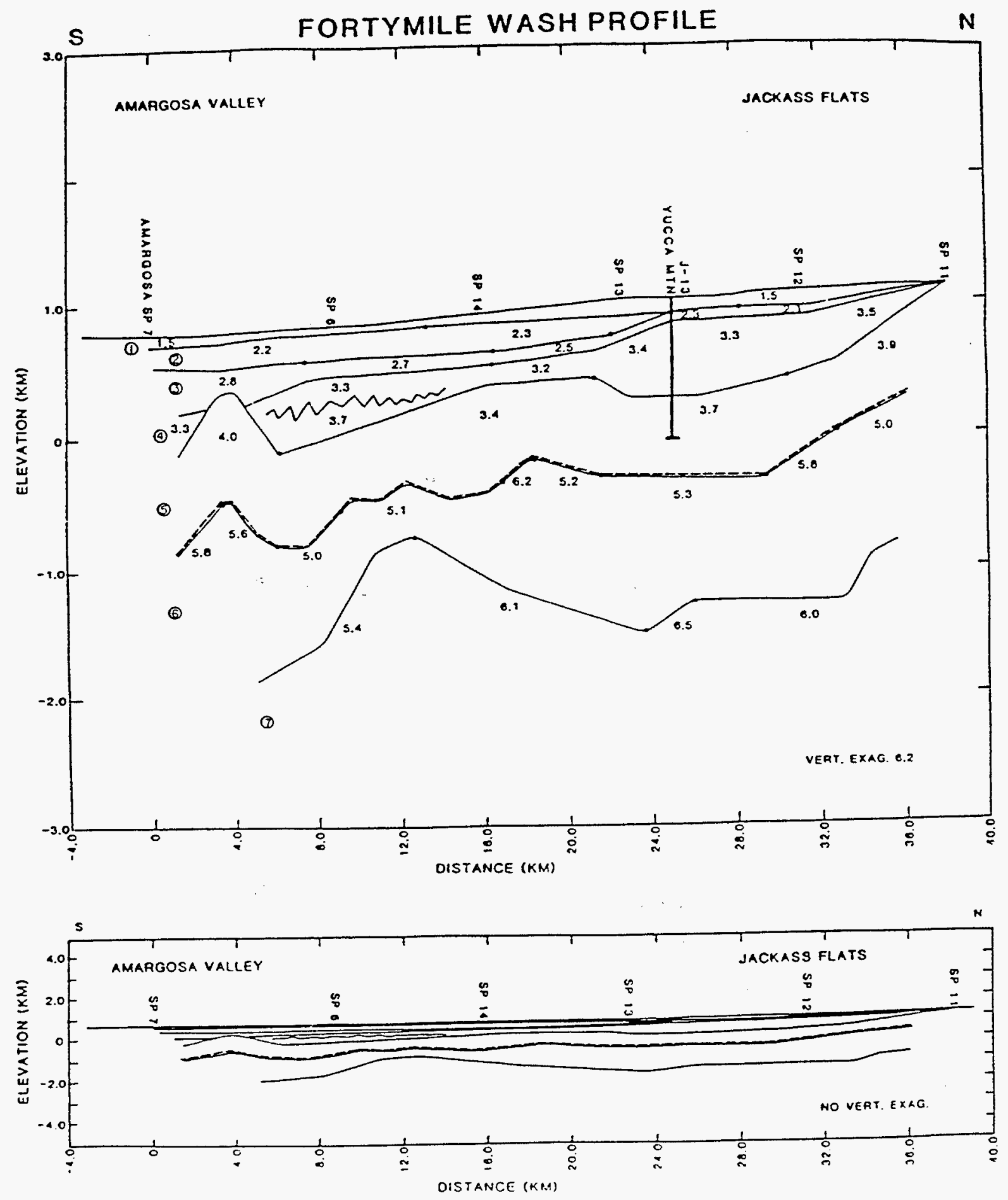

Figure 5.6. Crustal velocity section along the Fortymile Wash Profile. Seismic velocities are indicated in $\mathrm{km} / \mathrm{s}$. The inferred pre-Tertiary surface is shown by the dashed line, and layer numbers are circled. Well J-13 location and points of intersection with the other profiles are labeled. SP indicates approximate shotpoint locations. 
(2) well J-13 never penetrated pre-Tertiary rocks while piercing all five layers above layer 6, and (3) the pre-Tertiary surface ties with the Yucca Mountain profile at the top of layer 6. Although possibly related to varying degrees of fracturing, the lateral velocity variations comprising layer 6 are likely indicative of lithologic changes within the Paleozoic section, as this profile trends almost perpendicular to the inferred strike of Paleozoic units (M.D. Carr, and others, 1986).

A most interesting feature at the southern end of this section is the domal structure formed by layers 5 and 6 between shot points 6 and 7. The dome has a seismic velocity of 4.0 $\mathrm{km} / \mathrm{s}$ in layer 5 and completely transects layer 4 . Based on its geometry and the fact that it coincides with a strong magnetic anomaly (U.S. Geological Survey, 1978) similar to those produced by exposed Quaternary basaltic cones in the area, we suggest that it represents a buried Tertiary volcanic cone. This interpretation was previously postulated by W.J. Carr (1984) from magnetic data alone. Further supporting this interpretation, the irregular horizon to the north of the structure has a seismic velocity of $3.7 \mathrm{~km} / \mathrm{s}$ and is sandwiched between layers of lower velocity, highly suggestive of a large basalt flow which may have originated from the cone. The observation that layer 6 mimics the structure of layer 5 below the suggested cone infers that layer 6 does not necessarily represent the pre-Tertiary surface here. Its velocity of 5.6 to $5.8 \mathrm{~km} / \mathrm{s}$ may be attributable to a feeder-like structure of denser basic(?) material.

\section{Amargosa Profile}

On the velocity section (fig. 5.7) of the east-west profile through the Amargosa Valley (fig. 5.1), the interpretation of the depth to pre-Tertiary rocks was based on seismic velocity, horizon tying, and gravity (fig. 5.2) because the section does not benefit from any drill hole data. The inferred pre-Tertiary surface is represented by the dashed line. At the western end of the profile, the top of layer 6 at a depth of $0.6 \mathrm{~km}$ shows a marked increase in seismic velocity from $3.0 \mathrm{~km} / \mathrm{s}$ above to $6.1 \mathrm{~km} / \mathrm{s}$ in layer 6 , indicating that this is probably the preTertiary contact. Because the data are unreversed between shot points 20 and 29 , this surface is horizontal in the velocity section. The pre-Tertiary contact probably dips to the east here because Paleozoic rocks of the Funeral Mountains outcrop near shot point 29. This is also suggested by the eastward-decreasing gravity values (fig. 5.2). Layer 5 begins beneath shot point 20 with a seismic velocity of $3.5 \mathrm{~km} / \mathrm{s}$, and layer 6 continues lower in the section. The portion of layer 5 with the $3.5 \mathrm{~km} / \mathrm{s}$ velocity probably represents a melange of Tertiary volcanic rocks, alluvium, and Paleozoic slide blocks similar to the eastern flank of Bare Mountain as seen on the Yucca Mountain section (fig. 5.3). The inferred pre-Tertiary surface follows the top of layer 6 into a graben-like structure and proceeds to the top of layer 5 again, where it ties with the Crater Flat profile at $4.6 \mathrm{~km} / \mathrm{s}$. A large gravity low (fig. 5.2) beneath shot point 7 implies that the pre-Tertiary surface drops further, to the top of layer 6 where velocities are greater than $5.0 \mathrm{~km} / \mathrm{s}$, and ties with the Fortymile Wash Profile at a depth of about $1.8 \mathrm{~km}$. Changes in seismic velocity do not appear to be a valid indicator of the location of pre-Tertiary rocks here, presumably because deeply buried volcanic rocks seem to have velocities very similar to the upper surface of pre-Tertiary rocks on this profile (about $4.5 \mathrm{~km} / \mathrm{s}$ ). We interpret the pre-Tertiary surface to rise rapidly again to the top of layer 5 (4.2 $\mathrm{km} / \mathrm{s}$ ) about $2 \mathrm{~km}$ east of shotpoint 7 due to the presence of a steep gravity gradient (fig. 5.2; 

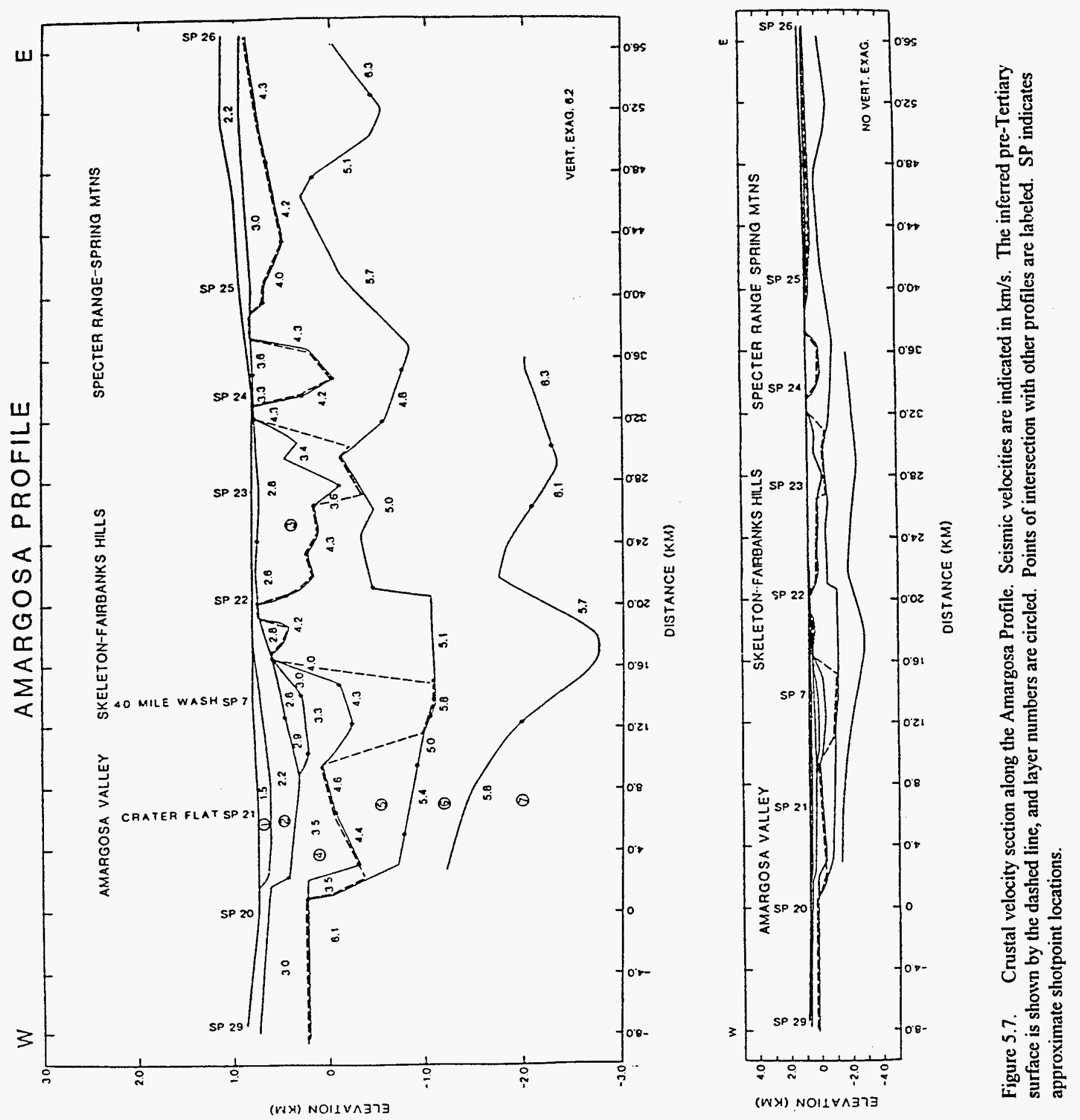
W.J. Carr, 1984) and outcropping Paleozoic rocks to the north and south of shot point 22 (Skeleton and Fairbanks Hills, respectively, fig. 5.1). The structural depression in the preTertiary surface which occurs between shot point 20 and $2 \mathrm{~km}$ east of shot point 7 is generally on trend with the Crater Flat structure. In addition, they have similar dimensions and are part of the same gravity low (fig. 5.2). We therefore conclude that the Crater Flat depression becomes narrower and shallower to the south as it continues into the Amargosa Valley.

East of shot point 22, the inferred pre-Tertiary surface follows the top of layer 5 into another structural depression where the velocity of layer 5 decreases from 4.3 to $3.6 \mathrm{~km} / \mathrm{s}$. Here the pre-Tertiary surface deepens to layer $6(5.0 \mathrm{~km} / \mathrm{s})$ again as layer 5 velocities become too low to represent Paleozoic rocks, and the gravity low (fig. 5.2) becomes more pronounced. About $2 \mathrm{~km}$ west of shot point 24 the pre-Tertiary surface is interpreted as being almost at the surface (top of layer $5,4.3 \mathrm{~km} / \mathrm{s}$ ) where the profile skirts Paleozoic outcrop in a southern arm of the Specter Range. The pre-Tertiary surface continues east along the top of layer 5 into another, more symmetric depression with velocities remaining at about $4.3 \mathrm{~km} / \mathrm{s}$. It rises again to accommodate another arm of the Specter Range and subsequently drops to a depth of about $0.7 \mathrm{~km}$ in a narrow valley between the Specter Range and Spring Mountains (fig. 5.1). The inferred depth of the pre-Tertiary surface in this narrow valley is questionable when considering how close the profile is to Paleozoic outcrop on the north and south.

This profile is anomalous in that the interpreted pre-Tertiary (Paleozoic) rocks have seismic velocities consistently lower than those inferred on the other profiles. This may be due in part to (1) extensive fracturing associated with the nearby, predominantly left-lateral Rock Valley fault zone (fig. 5.1); (2) a lesser degree of secondary cementation or hydrothermal alteration; (3) a lower grade of metamorphism; (4) a higher percentage of clastic material locally comprising the Paleozoic section; or (5) any combination of the four. Unfortunately, the material properties of these pre-Tertiary rocks are less well known than those closer to the potential repository site.

\section{EVIDENCE FOR DETACHMENT FAULTS}

Low-angle faults or detachment surfaces are exposed in the Funeral Mountains and west of Beatty in the Bullfrog Hills; these detachments are believed to accommodate Cenozoic crustal extension of at least 100 percent in the Nevada Test Site region (Hamilton, 1987). These structures juxtapose a highly-fractured Paleozoic section upon a metamorphosed Precambrian and Lower Cambrian section that has been ductilely extended and exhumed from mid-crustal levels. The Boundary Canyon Detachment is exposed about $10 \mathrm{~km}$ south of the Beatty profile in the Grapevine Mountains at an elevation of $1.0 \mathrm{~km}$ above sea level (Giarmita and others, 1983; Monsen, 1983). On the basis of the projected dip of the Boundary Canyon detachment and a gravity model constructed from velocity-density relationships, Ackermann and others (1988) suggested that the northward extension of this fault surface corresponds to the $5.7 / 6.3 \mathrm{~km} / \mathrm{s}$ seismic boundary on the Beatty profile beneath the Grapevine Mountains (fig. 5.5). The similarity of metamorphic lower-plate rocks at Boundary Canyon and the Bullfrog 
Hills suggests that the same detachment surface is exposed at both locales (W.J. Carr, 1984; Hamilton, 1987). The gravity model of Ackermann and others (1988) suggests from velocitydensity correlations that the detachment continues east of the Grapevine Mountains at a deeper level, well beneath the Bullfrog Hills, commensurate with the depth of the $6.2-6.4 \mathrm{~km} / \mathrm{s}$ layer reported by Hoffman and Mooney (1983) as far east as the fault separating Bare Mountain and Crater Flat. If the $5.7 / 6.3 \mathrm{~km} / \mathrm{s}$ seismic horizon represents the Boundary Canyon Detachment surface, then it must transcend refraction horizons on the Beatty profile to accommodate the detachment in the Bullfrog Hills. Clearly, if the detachments exposed in the Grapevine Mountains and the Bullfrog Hills are connected, even the crystalline lower plate rocks have highly depth-dependent seismic velocities and densities.

On the north flank of Bare Mountain, brittlely deformed Tertiary volcanic and sedimentary rocks rest in low-angle fault contact with the Late Precambrian and Paleozoic rocks of Bare Mountain. Metamorphic assemblages preserved in the lower-plate rocks on Bare Mountain and near Beatty suggest that this fault occupies the same structural position as the Boundary Canyon-Bullfrog Hills detachment (Monsen, 1983; Carr and Monsen, 1988). Should this be the case, then the detachment must remain near the surface east of the Bullfrog Hills (within the $4.8 \mathrm{~km} / \mathrm{s}$ layer, fig. 5.5) to accommodate the near-surface metamorphic rocks encountered in numerous mining operations between the Bullfrog Hills and Beatty (M.D. Carr, oral communication, 1988) and those that crop out south of Beatty (fig. 5.1). East of Beatty, the detachment occurs at or below the pre-Tertiary surface, possibly corresponding to the top of the $5.7-5.9 \mathrm{~km} / \mathrm{s}$ layer 6 .

In outcrops of lower-plate rocks, metamorphic grade is observed to increase to the northwest in the Nevada Test Site region (Hamilton, 1988), supporting our interpretation of the location of the Boundary Canyon-Bullfrog Hills-Bare Mountain detachment (heavy dashed line, fig. 5.8) in that lower-plate seismic velocities at similar levels are higher in the Grapevine Mountains than at Bare Mountain. Hamilton (1988) believes that the metamorphic-grade trend reflects a single northwest-dipping detachment surface that cut increasingly shallower crust to the southeast. An alternative hypothesis that better accommodates the ascent of the detachment between the $5.7 / 6.3 \mathrm{~km} / \mathrm{s}$ horizon beneath the Grapevine Mountains and the Bullfrog Hills (fig. 5.8) involves a second, deeper detachment surface (queried light dashed line) connecting the $5.7 / 6.3 \mathrm{~km} / \mathrm{s}$ horizon beneath the Grapevine Mountains with the $6.2-6.4$ $\mathrm{km} / \mathrm{s}$ layer reported by Hoffman and Mooney (1983), similar to the inferred detachment seen in the gravity model of Ackermann and others (1988).

Interpretations of the eastward extent of the Boundary Canyon-Bullfrog Hills-Bare Mountain detachment system and its relationship to faulting at Yucca Mountain, $15 \mathrm{~km}$ east of Bare Mountain, are controversial. An important question concerns whether the exposed normal faults at Yucca Mountain flatten to an active detachment surface at the pre-Tertiary boundary beneath Crater Flat or penetrate deeper into the crust before they are accommodated by a low-angle detachment surface either within pre-Tertiary strata or the present-day brittle-ductile transition. An interesting observation is that the basal seismic horizons on the east-west Yucca Mountain and Amargosa velocity sections (figs. 5.3 and 5.7) exhibit maxima and minima in depth that could conceivably account for the overlying 

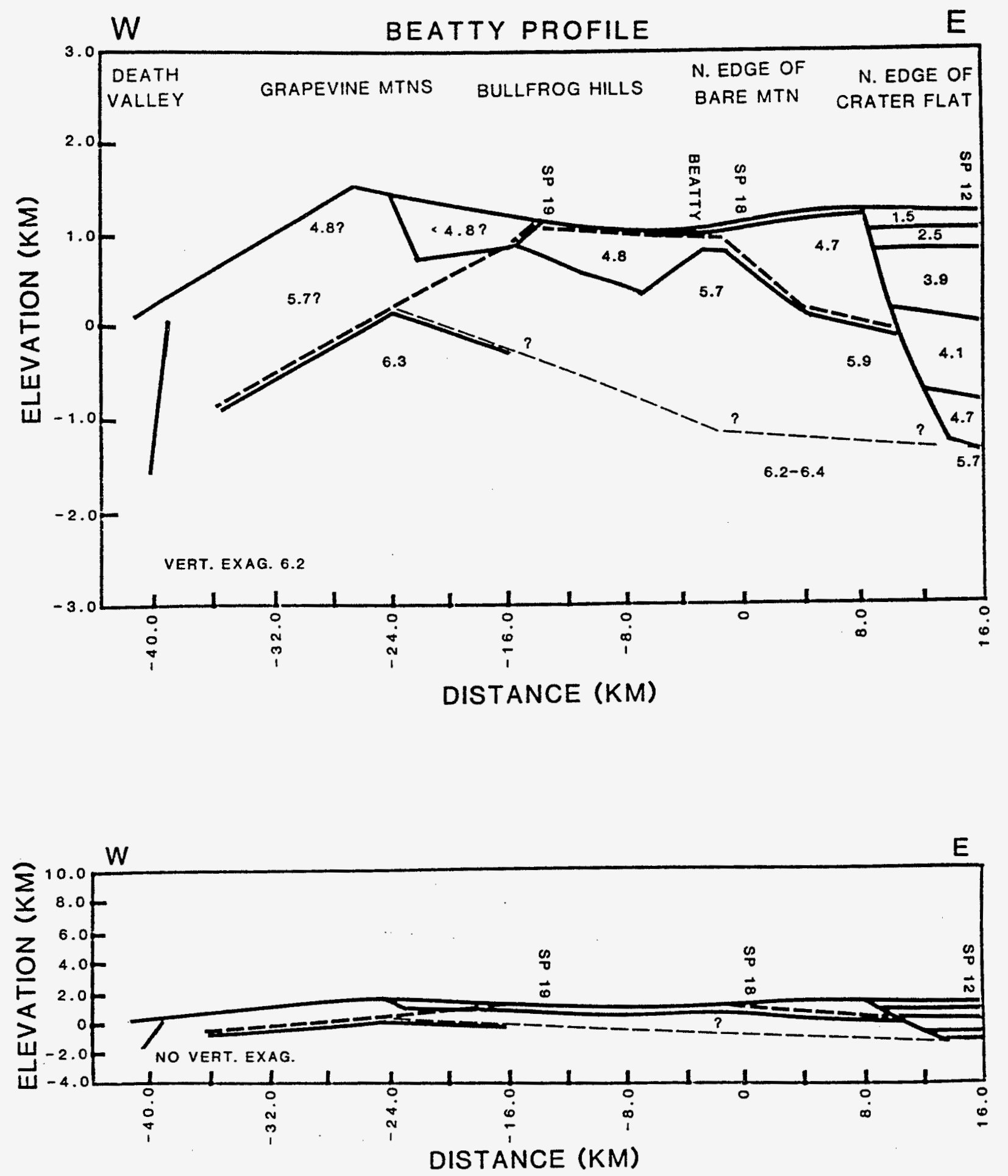

Figure 5.8. Velocity section along the Beatty profile showing the inferred location of Tertiary detachment faults. The seismic horizons shown are only those produced by the data inversion, and seismic velocities are given in $\mathrm{km} / \mathrm{s}$. The geometry of the $<4.8 \mathrm{~km} / \mathrm{s}$ (?) layer between the east flank of the Grapevine Mountains and the Bullfrog Hills (where refraction data are lacking) is based on a low-density basin structure in the gravity model of Ackermann and others (1988). The depth to the top of the $6.3 \mathrm{~km} / \mathrm{s}$ layer beneath the Grapevine Mountains is constrained by northward extrapolation of the dip of the Boundary Canyon Detachment. The heavy dashed line is the inferred location of the Boundary Canyon-Bullfrog Hills-Bare Mountain detachment system constrained by surface geology. The lighter dashed line represents the inferred location of a second, deeper extension of the Boundary Canyon detachment based on seismic velocities and the gravity model of Ackermann and others (1988). 
structure by block rotation on these surfaces. In addition, the top of the basal layer 7 on the Yucca Mountain section beneath the Amargosa Valley (fig. 5.3) is at the same depth and has approximately the same velocity as the inferred deeper detachment surface on the Beatty profile (fig. 5.8). If the inferred deeper detachment on the Beatty profile can be extended south beneath the Amargosa Valley to the top of layer 7 on the Yucca Mountain profile and if it is a detachment, then it would appear that this detachment is the pre-Tertiary surface beneath Crater Flat (fig. 5.3). However, considering the lack of geologic control at these depths, it is unlikely that any solid conclusions can be drawn from this observation.

\section{CONCLUSIONS}

Interpretation of five seismic refraction profiles in the vicinity of Yucca Mountain defines the potential waste-repository site as overlying complex extensional features manifested in the pre-Tertiary strata. The velocity contrast between the Tertiary and preTertiary sections is large enough that, when interpreted with the aid of gravity data, a reliable representation of the pre-Tertiary surface is produced. Where tectonic brecciation or hydrologic dissolution has significantly lowered the competence (and velocity) of the preTertiary rocks, gravity may be a more accurate indicator of the depth to the pre-Tertiary contact.

The inferred pre-Tertiary surface on the Yucca Mountain velocity section (fig. 5.3) reveals the structural depression underlying Tertiary rocks in the vicinity of Yucca Mountain. The Tertiary section is a maximum of about $3.5 \mathrm{~km}$ thick within Crater Flat (fig. 5.3). The Crater Flat depression is an asymmetric, westward-deepening structure that extends in eastwest profile from the east flank of Bare Mountain as far east as eastern Yucca Mountain. Beneath eastern Yucca Mountain, the Tertiary section is $1.25 \mathrm{~km}$ thick where pre-Tertiary rocks form a localized relative high at the latitude of the Yucca Mountain profile. The Amargosa velocity section (fig. 5.7) and gravity data (fig. 5.2) suggest that the depression extends at least as far south as the Amargosa Valley at the latitude of the Amargosa profile. The Crater Flat depression was interpreted as a Miocene caldera by Snyder and Carr (1984), but its structural extension beyond Crater Flat and recent evidence that the faults separating Bare Mountain and Crater Flat pre-date the Crater Flat Tuff (Oliver and Ponce, chap. 1, this report) suggest that such volcanism was localized within a larger and longer-lived extensional structure. The Crater Flat velocity section (fig. 5.4) shows that this Crater Flat-Amargosa graben is almost twice as deep in Crater Flat $(3.2 \mathrm{~km})$ as it is to the south in the Amargosa Valley $(1.8 \mathrm{~km})$; this may be the result of caldera-forming volcanism in Crater Flat subsequent to the formation of the graben. In agreement with the gravity model of Snyder and Carr (1984), the Fortymile Wash velocity section (fig. 5.6) reveals that the pre-Tertiary basement high beneath eastern Yucca Mountain continues to rise to the north but deepens gradually into the Crater Flat-Amargosa graben system to the south. In addition, this profile identified a suspected buried Tertiary volcanic center just south of Lathrop Wells.

In most cases, the seismic refraction horizons in the Tertiary section in and around Yucca Mountain do not correlate with formational boundaries encountered in drill holes. We 
believe that the velocity contrasts at many formational contacts are not as strong as those found within formations. Lateral seismic velocity changes are probably indicative of lava flows or variations in the degree of welding, fracturing, or cementation, while vertical velocity contrasts are related to confining pressure. Some lateral changes that are expressed as seismic layer terminations beneath Yucca Mountain (fig. 5.3) may be caused by the juxtaposition of Tertiary units that have been buried at significantly different levels by major normal faults such as the Solitario Canyon fault. Seismic velocities in the Tertiary section range from less than $2.0 \mathrm{~km} / \mathrm{s}$ at the surface of Yucca Mountain to at least $4.7 \mathrm{~km} / \mathrm{s}$ in the deeper parts of Crater Flat.

The range in seismic velocities for pre-Tertiary rocks in the area reflect the large effect that fracturing has on near-surface rocks. In the deeper parts of Crater Flat, where lithostatic pressures have closed fractures and pores, the velocities of pre-Tertiary rocks are between 5.7 and $6.8 \mathrm{~km} / \mathrm{s}$. At shallower depths, these velocities are often considerably less, as low as 4.7 $\mathrm{km} / \mathrm{s}$ within $1.0 \mathrm{~km}$ of the surface. On the Amargosa section, velocities of pre-Tertiary rocks at this depth are lower still at $4.4 \mathrm{~km} / \mathrm{s}$, and those rocks at or near the surface have seismic velocities as low as $4.2 \mathrm{~km} / \mathrm{s}$. The consistently lower pre-Tertiary velocities on the Amargosa section are poorly understood as those rocks are not well studied in outcrop.

It is unlikely that a single detachment surface has been active during the Cenozoic extension period in this region. Two extensions of the Boundary Canyon Detachment into the Yucca Mountain area are speculated upon here, but they need to be confirmed with new data across the northern Amargosa Valley. The modern detachment surface that accommodates fault movement seen at the surface on Yucca Mountain may coincide with the pre-Tertiary contact beneath Crater Flat based on the geometry of some deep refracting horizons. The addition of high-quality seismic reflection data to our geophysical database will help to resolve these issues. 


\section{REFERENCES CITED}

Ackermann, H.D., Pankratz, L.W., and Dansereau, D.A., 1982, A comprehensive system for interpreting seismic refraction arrival-time data using interactive computer methods: U.S. Geological Survey Open-File Report 82-1065, 265 p.

Ackermann, H.D., Mooney, W.D., Snyder, D.B., and Sutton, V.D., 1988, Preliminary interpretation of seismic refraction and gravity studies west of Yucca Mountain, Nevada and California, in Carr, M.D. and Yount, J.C., eds., Short contributions to the geology and hydrology of a potential nuclear waste disposal site at Yucca Mountain, southern Nevada: U.S. Geological Survey Bulletin 1790, p. 23-34.

Carr, M.D., and Monsen, S.A., 1988, A field trip guide to the geology of Bare Mountain, in Weide, D.L., and Faber, M.L., eds., This extended land, geological journeys in the southern Basin and Range: Geological Society of America Cordilleran Section, Field Trip Guidebook, p. 50-57.

Carr, M.D., Waddell, S.J., Vick, G.S., Stock, J.M., Monsen, S.A., Harris, A.G., Cork, B.W., and Byers, F.M., 1986, Geology of drill hole UE-25p\#1: A test hole into pre-Tertiary rocks near Yucca Mountain, southern Nevada: U.S. Geological Survey Open-File Report $86-175,87 \mathrm{p}$.

Carr, W.J., 1982, Volcano-tectonic history of Crater Flat, southwestern Nevada, as suggested by new evidence from drill hole USW VH-1 and vicinity: U.S. Geological Survey OpenFile Report 82-457, 23 p.

Carr, W.J., 1984, Regional structural setting of Yucca Mountain, southwestern Nevada, and Late Cenozoic rates of tectonic activity in part of the southwestern Great Basin, Nevada and California: U.S. Geological Survey Open-File Report 84-854, 109 p.

Carr, W.J., and Parrish, L.D., 1985, Geology of drit hole USW VH-2 and structure of Crater Flat, southwestern Nevada: U.S. Geological Survey Open-File Report 85-475, 41 p.

Giarmita, M., Day, H.W., and Troxel, B.W., 1983, Structural, metamorphic, and plutonic evolution of the northern Funeral Mountains, Death Valley, California [abs.]: Geological Society of America, Abstracts with Programs, v. 15, no. 5, p. 419.

Hamilton, W.B., 1987, Crustal extension in the Basin and Range Province, southwestern United States, in Coward, M.P., Dewey, J.F., and Hancock, P.L., eds., Continental extensional tectonics, Geological Society Special Publication No. 28, p. 155-176.

Hamilton, W.B., 1988, Detachment Faulting in the Death Valley region, California and Nevada, in Carr, M.D. and Yount, J.C., eds., Short contributions to the geology and hydrology of a potential nuclear waste disposal site at Yucca Mountain, southern Nevada: U.S. Geological Survey Bulletin 1790, p. 51-85. 
Hoffman, L.R., and Mooney, W.D., 1983, A seismic study of Yucca Mountain and vicinity, southern Nevada; data report and preliminary results: U.S. Geological Survey Open-File Report 83-588, 50 p., I plate.

Monsen, S.A., 1983, Structural evolution and metamorphic petrology of Precambrian strata, northwest Bare Mountain, Nevada: M.S. Thesis, University of California at Davis.

Pankratz, L.W., 1982, Reconnaissance seismic refraction studies of Calico Hills, Wahmonie, and Yucca Mountain, southwest Nevada Test Site, Nye County, Nevada: U.S. Geological Survey Open-File Report 82-478, 25 p.

Scott, R.B., and Castellanos, M., 1984, Stratigraphic and structural relations of volcanic rocks in drill holes USW GU-3 and USW G-3, Yucca Mountain, Nye County, Nevada: U.S. Geological Survey Open File Report 84-491, 121 p., 1 plate.

Snyder, D.B., and Carr, W.J., 1982, Preliminary results of gravity investigations at Yucca Mountain and vicinity, southern Nye County, Nevada: U.S. Geological Survey Open-File Report 82-701, 35 p.

Snyder, D.B., and Carr, W.J., 1984, Interpretation of gravity data in a complex volcanotectonic setting, southwestern Nevada: Journal of Geophysical Research, v. 89, no. B12, p. $10193-10206$.

Sutton, V.D., 1984, Data report for the 1983 seismic refraction experiment at Yucca Mountain, Beatty, and vicinity, southwestern Nevada: U.S. Geological Survey Open-File Report 84-661, 66 p., 11 plates.

Sutton V.D., 1985, Data report for the 1985 seismic refraction experiment at Yucca Mountain and vicinity, southwestern Nevada: U.S. Geological Survey Open-File Report 85-591, 96 p., 17 plates.

Thodarson, W., 1983, Geohydrologic data and test results from well J-13, Nevada Test Site, Nye County, Nevada: U.S. Geological Survey Water-Resources Investigations Report 83$4171,57 \mathrm{p}$.

U.S. Geological Survey, 1978, Aeromagnetic map of the Lathrop Wells area: U.S. Geological Survey Open-File Report 78-1103, scale 1:62,500.

U.S. Geological Survey, 1984, A summary of geologic studies through January 1, 1983, of a potential high-level radioactive waste repository site at Yucca Mountain, southern Nye County, Nevada: U.S. Geological Survey Open File Report 84-792, 103 p. 


\title{
MAJOR RESULTS OF GEOPHYSICAL INVESTIGATIONS AT YUCCA MOUNTAIN AND VICINITY, SOUTHERN NEVADA
}

\section{CHAPTER 6: SEISMIC REFLECTION INVESTIGATIONS}

\author{
By Thomas M. Brocher
}

\section{INTRODUCTION}

\begin{abstract}
Seismic reflection methods provide the highest resolution of the subsurface offered by any geophysical method. Reflection methods are used to establish the continuity and regularity of important stratigraphic contacts and to determine the major structural and tectonic components of the crust through the mapping of seismic impedance contrasts. Seismic impedance is the product of seismic velocity or density, and thus reflection methods are used to map relatively abrupt changes in the seismic velocities and densities of rocks. This chapter summarizes seismic reflection investigations conducted in the vicinity of Yucca Mountain, at Mid Valley, and in the Amargosa Desert. Plans for future seismic reflection investigations in the Yucca Mountain region are also presented.
\end{abstract}

\section{INVESTIGATIONS AT YUCCA MOUNTAIN}

A number of seismic reflection studies have been carried out in association with the Yucca Mountain Site Characterization Project (Oliver and others, 1990, p. 60-62). Several field surveys have been conducted using shallow reflection methods with portable equipment and limited geophone deployment (Harding, 1988). Much of the work has been performed using the Mini-Sosie method (Barbier, 1983), which is a small, versatile, high-resolution reflection technique. The salient aspects of this method are that it uses a closely spaced array of single geophones and one or more portable soil compaction vibrators as the source(s). Data quality is achieved by stacking a large number of traces, each triggered from a single vibrator cycle. Randomization of the vibrator repeat period suppresses contributions from extraneous vibrator cycles. The method can produce useful reflections at depths corresponding to two-way travel times (twtt) of about 0.3 to $1.0 \mathrm{~s}$, depending on site conditions, and therefore the uppermost 50 to $150 \mathrm{~m}$ (depending on velocity) cannot be imaged by this method.

The following items summarize the shallow, Mini-Sosie reflection studies performed by the USGS, Branch of Geologic Risk Assessment (for example, Harding, 1988) through 1993 under the Yucca Mountain Site Characterization Project:

1. A profile was acquired over the Carpetbag and Yucca faults, using the Mini-Sosie method. The part of the line crossing the Carpetbag fault produced useful results, interpreted as tuff of the Rainier Mesa Tuff of the Miocene Timber Mountain Group (Sawyer and others, 1994) dipping steeply into the Yucca Flat basin, with no indication of fault offset. This led to the speculation that, at least at the profile location, the inferred post-event faulting was caused 
by compaction of alluvium and slip on the steeply dipping Rainier Mesa Tuff. The part of the line crossing the Yucca fault yielded no useful information, probably because the Rainier Mesa Tuff lies below I $\mathrm{s}$ two-way travel time, and there is no interpretable reflecting horizon in the overlying alluvium.

2. An east-west line approximately $1.1 \mathrm{~km}$ in length was run across the Beatty scarp (fig. 1.7), about $4 \mathrm{~km}$ south of Beatty, Nevada (Harding, 1988). The profile shows two bands of reflections which are coherent beneath the Beatty scarp. The relative incoherency of the section was attributed to low contrasts between geologic layers, residual statics problems, and scattering by boulders near the surface (Harding, 1988). Extension of a fault from the surface scarp to a part of the section that suggests offset would require reverse motion on a fault plane dipping 30 degrees to the west. This dip is inconsistent with the regional predominance of normal slip on north-striking faults, and therefore Harding (1988) opined that the Beatty scarp is not fault-related.

3. An east-west line was run across a fault scarp (Windy Wash fault) in Crater Flat (fig. 1.7) that had been investigated by means of several nearby trenches (Swadley and Hoover, 1983; Harding, 1988). The near-surface velocity structure was found to be complex. A (common data point) CDP-sorting and constant-velocity analysis was used to determine residual statics, which were correlated somewhat with the surface distribution of Quaternary alluvial materials and extrusive Tertiary volcanic rocks. A single reflecting horizon which exhibited dipping parts and fault offset was traced across the section. Subsurface faulting indications were related to, but different from, those observed in nearby surface trenches. The results were interpreted not to support normal faulting mechanisms, but to be consistent with strike-slip faulting.

4. An east-west line was run from the east slope of Bare Mountain, between the two volcanic cones in central Crater Flat, and then further into the basin toward Yucca Mountain (fig. 1.7). Some reflected energy was observed; the data were, however, of insufficient quality to substantially support or challenge the structural model of W. Carr (1988; also Harding, 1988; and Swadley and others, 1988).

5. Two other lines, one in Tarantula Canyon in the Bare Mountain block, the other along the old railroad bed east of Lathrop Wells, Nevada, produced few if any coherent reflections.

In addition to the Mini-Sosie work, several reflection studies of a more conventional type were performed in the Yucca Mountain site area during the 1980-1982 time period. These are described in a summary report (McGovern and others, 1983) as three distinct surveys undertaken by different organizations: Colorado School of Mines (conducted in 1980), Birdwell Well Services Incorporated (in 1981), and Seisdata (in 1982). The recording windows for these surveys generally extended beyond 1 second, but they are here considered to be high-resolution because (1) high-frequency sources were used (small explosive charges; vibrator sweeps to more than $100 \mathrm{~Hz}$ ), (2); the receiver arrays were small, and (3) the lines were located in the immediate site area. These surveys were thus designed to investigate shallow reflectors, of which there may be several in the first second. The summary report 
presents negative results from these surveys and states that useful seismic reflection data cannot be acquired from the Yucca Mountain site area. This conclusion was based largely on the 1982 survey. That survey was limited, however, not representing true swath surveys or three-dimensional surveys, and the results very likely do not represent all methods available for seismic reflection exploration.

For a variety of reasons, including the lateral discontinuity of reflectors, reflections from the shallow crust are not always obtained, especially on short profiles. For instance, the short reflection profiles discussed by McGovern and others (1983) failed to obtain reflections from within the welded tuff on the east side of Yucca Mountain. While it is difficult to assess the reasons why a particular seismic profile failed to image a structure of interest, it seems likely that the acquisition parameters used in studies described by McGovern and others (1983) were not optimal for interpretable images. Because more recent reflection profiling on the Nevada Test Site (McArthur and Burkhard, 1986) and in the Amargosa Desert (Brocher and others, 1993) documents that useful shallow data can be obtained in the vicinity of Yucca Mountain, the conclusion of McGovern and others (1983) that useful reflection profiles cannot be obtained near Yucca Mountain is controversial.

In 1993 three short (totaling $5 \mathrm{~km}$ ) high-resolution (50 to $250 \mathrm{~Hz}$ ) seismic reflection profiles at Yucca Mountain were acquired by Ernie Majer and staff of the Lawrence Berkeley Laboratory. The lines, respectively, run down Drillhole Wash, cross the Ghost Dance fault, and run along the crest of Yucca Mountain. The profiles were acquired with a 13-m (40-foot) seismometer spacing and a 30,000 ft-lb impact source operated at 3-m (10-foot) intervals, producing 24-fold data (E.L. Majer, personal communication, 1994; Daley and others, 1994). Preliminary interpretation of these data, reported by Oliver and others (1994), suggests that the Ghost Dance fault is just part of a complex zone of faulting and fracturing that is several hundred meters wide. The width of the zone appears to extend downward to a depth of about $1 \mathrm{~km}$.

\section{INVESTIGATIONS AT MID VALLEY}

McArthur and Burkhard (1986) presented high-quality reflection profiles from Mid Valley, located about $25 \mathrm{~km}$ northeast of Yucca Mountain on the Nevada Test Site (fig. 6.1). These profiles reveal a number of Miocene and younger structures. Well control indicates that reflections were obtained from the Miocene Thirsty Canyon Group (Sawyer and others, 1994), a tuff-alluvium contact, and the base of the Miocene Timber Mountain Group. Reflections inferred to represent the top of the Paleozoic section and a subhorizontal detachment fault are also observed on these profiles. The 48 -fold profiles were obtained using a land-airgun source array and indicate that the depth to the top of the Paleozoic basement rocks is approximately $1500 \mathrm{~m}$. Offsets of reflections from the basins were used to infer that high-angle normal faults of Tertiary age are truncated at depth by the subhorizontal detachment faults. These sections document that seismic reflection profiling provides valuable constraints on the Tertiary basins within the Nevada Test Site, even in regions where there are extensive tuff deposits. 


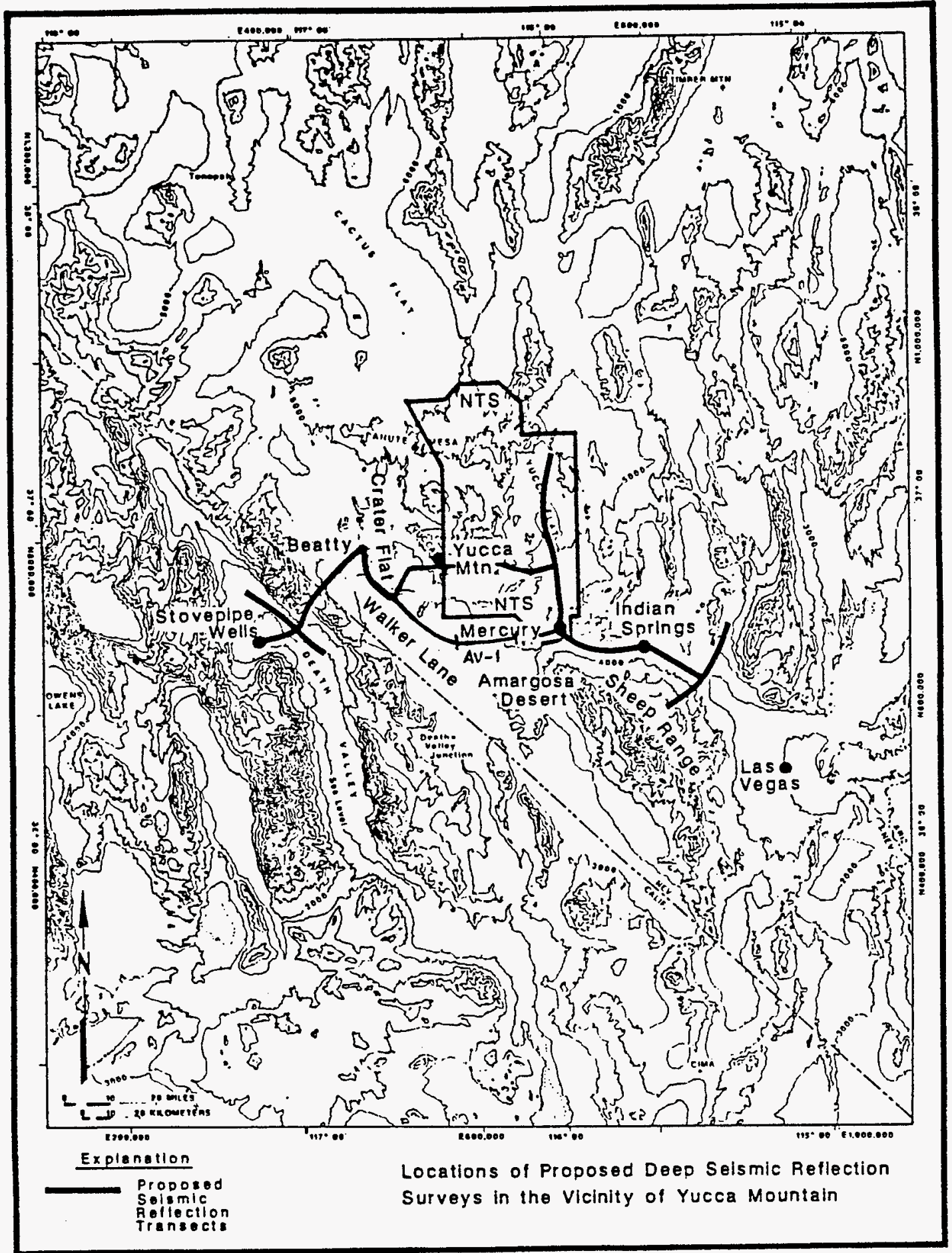

Figure 6.1. Location map showing existing and proposed deep seismic reflection surveys in the vicinity of Yucca Mountain. The Amargosa Desert reflection profile (Brocher and others, 1993) is indicated (AV-1). 


\section{INVESTIGATIONS AT AMARGOSA DESERT}

In January 1988, the U.S. Geological Survey conducted a detailed field comparison of explosion and vibrator methods for acquiring deep crustal seismic reflection profiles in the Amargosa Desert, $30 \mathrm{~km}$ south of Yucca Mountain, in Nye County, Nevada (Brocher and others, 1990). Extensive testing of the Vibroseis method was performed at two sites within the Amargosa Desert to establish optimal acquisition parameters for the Vibroseis source. On completion of this exhaustive suite of trials, a 60 -fold Vibroseis ${ }^{\mathrm{TM}}$ profile along a $27-\mathrm{km}$-long line (Line AV-1; fig. 6.1) was acquired using a 12-km-long symmetric split spread. Single 91$\mathrm{kg}$ explosive charges were fired in 76-m-deep shotholes along the Vibroseis ${ }^{\mathrm{TM}}$ profile to generate a coincident single-fold explosive-source reflection profile. Brocher and Hart (1991) concluded that within the upper crust (upper $5 \mathrm{~s}$ twtt) the explosive and Vibroseis ${ }^{\mathrm{TM}}$ commonshot records are nearly equivalent (fig. 6.2). The 60-fold vibrator section for the upper $5 \mathrm{~s}$ twtt is of high quality and clearly shows structures related to Tertiary extension (fig. 6.3). Delaw. $5 \mathrm{~s} \mathrm{twtt}$, however, the final sections for the coincident explosion and Vibroseis ${ }^{\mathrm{TM}}$ sources document that thesingle-fold explosion source section is a higher-quality image of the lower crust ( 5 to $10 \mathrm{~s} \mathrm{twtt)}$ due to the higher seismic energy levels produced by the explosion sources and to the virtual absence of the air wave arrival on the shot hole data. The explosion source profile reveals subhorizontal discontinuous reflections between 5 to $10 \mathrm{~s}$ twtt (fig. 6.4). Based on older, and limited, seismic refraction data, the crust was believed to be about $35 \mathrm{~km}$ thick. On the reflection profiles obtained by this Amargosa study, the base of the crust is illdefined but inferred to be at 9 to $10 \mathrm{~s}$ twtt, judging from the absence of high-amplitude reflected arrivals below that depth (Brocher and others, 1993).

Brocher and others (1993) used outcrops, shallow well control, and coincident geophysical surveys to interpret seismic reflection Line AV-1. The east-west, 27-km-long seismic line crosses all or parts of three Tertiary subbasins revealing that basin growth occurred by progressive shifts of basin bounding faults. The reflection line images Tertiary strata rotated by steeply-dipping listric faults and nosing into normal faults. A shallow (less than 100 to $200 \mathrm{~m}$ deep), laterally continuous, flat-lying, low-frequency reflector, interpreted as a Tertiary basalt flow, suggests that little vertical deformation has occurred within the easternmost of the small Tertiary basins since the eruption of the flow about 10 million years ago. Moderately dipping reflections within the pre-Tertiary bedrock may represent images of Mesozoic thrust faults. The reflection data indicate that, whereas the top of the reflective lower crust is shallower to the west, possibly in the direction of increasing crustal extension, the Moho is relatively flat and between 30 and $33 \mathrm{~km}$ deep. Apparent bright spot reflections from the lower crust are interpreted as evidence for ductile shearing of the lower crust, not for active magma chambers. Doming of the lower crust resembles that inferred elsewhere in the Basin and Range Province, and it is consistent with ductile flow in the lower crust.

\section{FUTURE INVESTIGATIONS}

Based on the studies described above, potential reflecting horizons have been 


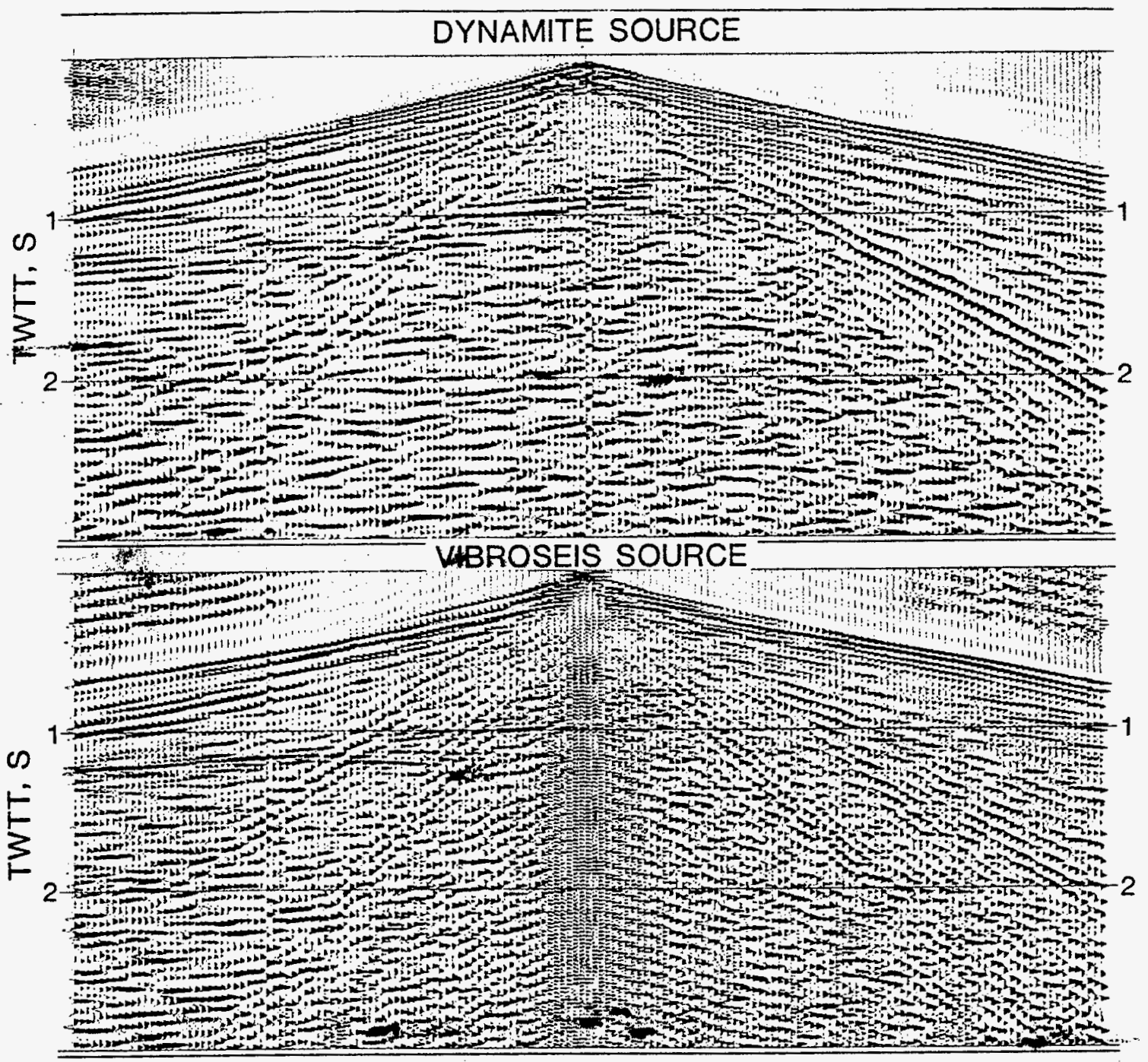

Figure 6.2. Comparison of records obtained using explosive and Vibroseis sources at the same location. Note the reflections on both records at about $1 \mathrm{~s}$. For these plots the maximum offsets are $2 \mathrm{~km}$ and the amplitudes of both records have been automatically gain-controlled. 


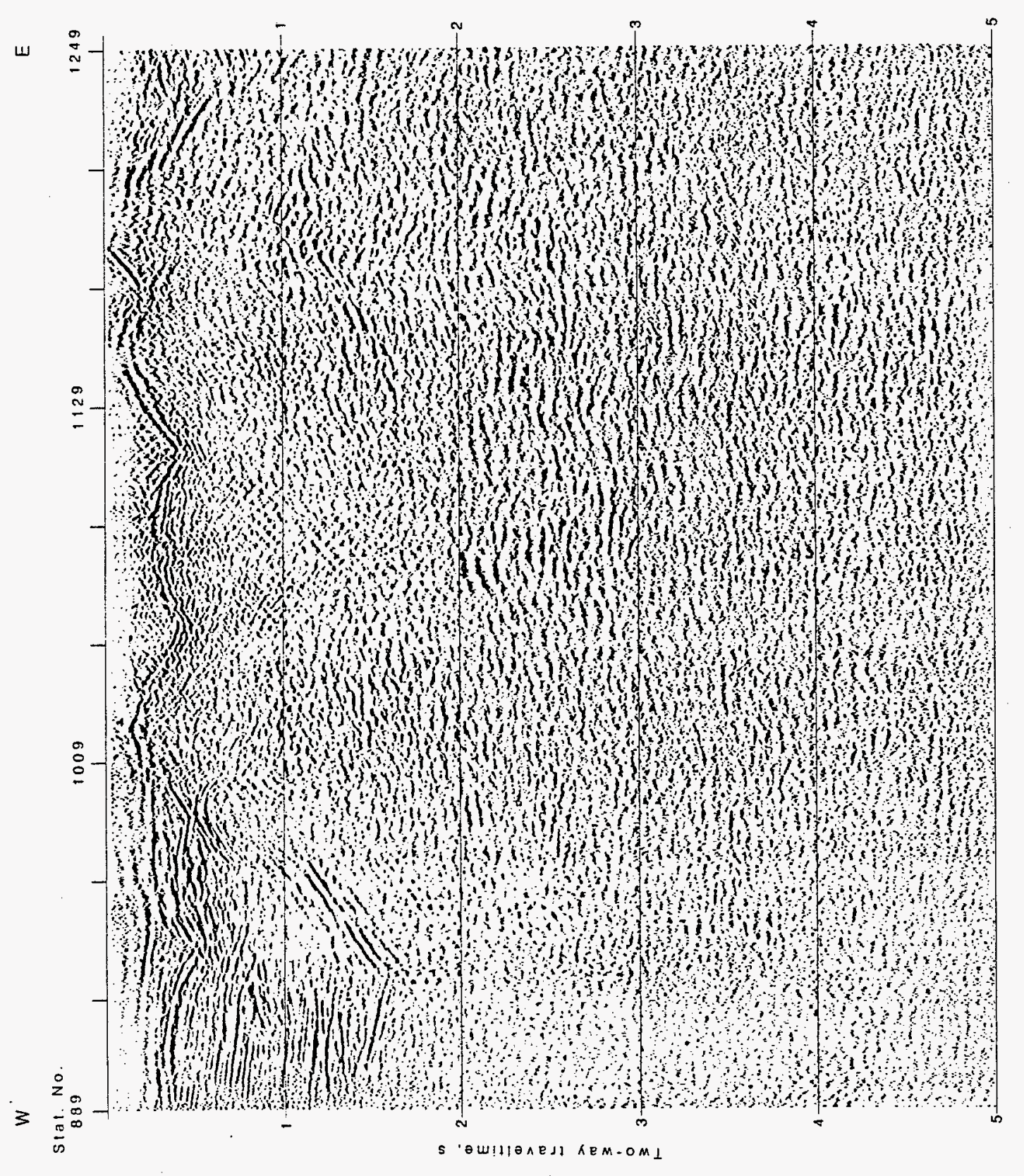

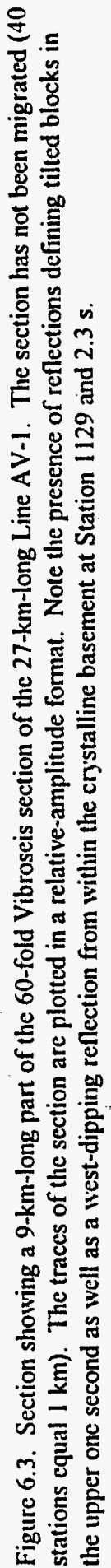




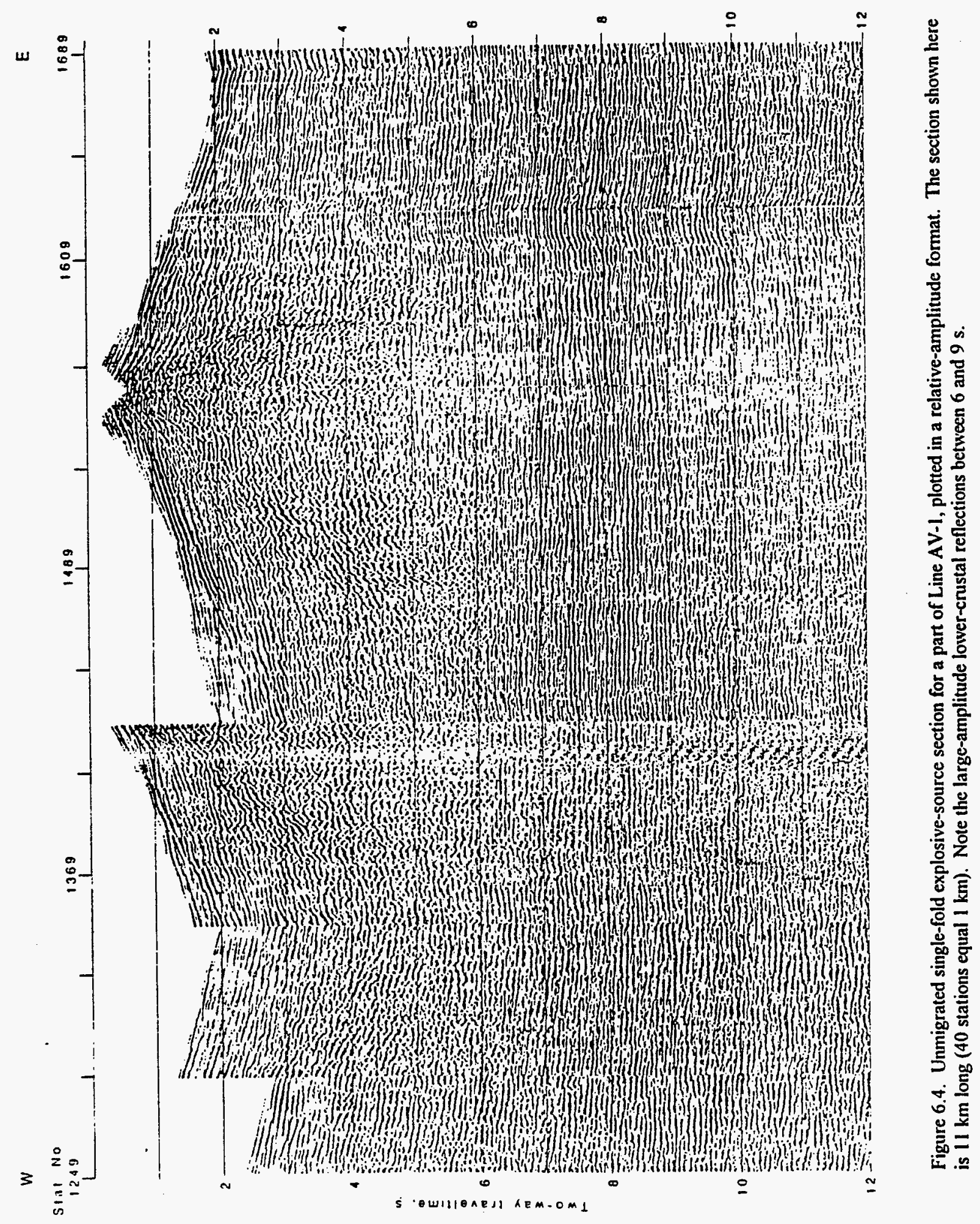


identified at all levels of the crust. In the southern Great Basin they include Miocene and younger tuffs and ash-fall tuffs (McArthur and Burkhard, 1986), the upper and lower carbonate aquifers within the Paleozoic stratigraphic section (Winograd and Thordarson, 1975); the mylonitic, detachment-bounded, upper surface of strongly metamorphosed Precambrian rocks exposed in the northern Amargosa Desert; the Paleozoic-Tertiary contact in the Yucca Mountain region; the mid-crustal, ductile-brittle transition zone, found at about 5 $\mathrm{s}$ twtt in Death Valley (deVoogd and others, 1986) and at about $6 \mathrm{~s}$ twtt in the Amargosa Desert (Brocher and others, 1993).

A hybrid-source reflection survey, utilizing vibrators, minihole explosive sources, and Poulter (surface) charges (Poulter, 1950), and designed to map the geometry of the preTertiary to Tertiary contact has now been conducted (in 1994) across Crater Flat and Yucca Mountain in the vicinities of boreholes $\mathrm{VH}-1, \mathrm{H}-3$, and UE-25 $\mathrm{pHl}$ (Brocher and others, 1995). These 60-fold vibrator profiles (94-fold for Poulter charges and 125 -fold for minihole sources) totaling $37 \mathrm{~km}$ were recorded to a depth of $8 \mathrm{~s} \mathrm{twtt} \mathrm{(fig.} \mathrm{6.5).} \mathrm{These} \mathrm{profiles} \mathrm{help}$ determine the geometry of Tertiary sedimentary and volcanic units in the vicinity of Yucca Mountain and help test alternative hypotheses for the origin of Crater Flat (see chap. 1) and the geologic/tectonic setting of Yucca Mountain. Large explosive shotholes containing up to $91 \mathrm{~kg}$ of explosive charges also were fired at 2-km intervals along the profiles to obtain images of the reflective lower crust and the Moho. Gravity and magnetic profiles were obtained coincident to the seismic profiles. Reports on this work are in preparation at this writing.

Recent studies indicate that variations in the depth to the top of the reflective lower crust, thought to represent the brittle-ductile transition of the mechanical behavior of the crust, may reflect spatial variations in heat flow and fluid migration in the middle crust (Klemperer, 1987). This transition occurs at $5 \mathrm{~s}$ twtt (about $15 \mathrm{~km}$ depth) on COCORP reflection profiles (Klemperer and others, 1986) in Death Valley and between 4 and $6 \mathrm{~s}$ twtt in the Amargosa Desert (fig: 6.4), corresponding to depths of roughly 12 to $18 \mathrm{~km}$ (Brocher and others, 1993).

Both the COCORP profiles (Klemperer and others, 1986) and Line AV-1 in the Amargosa Desert (Brocher and others, 1993) reveal reflections from a zone near the base of the crust. The thickness of the crust is also of fundamental importance for determining the mechanical properties and recent history of the crust. Variations in the crustal thickness as defined by the 10-s boundary (27 to $30 \mathrm{~km}$ deep) found in the Amargosa Desert (fig. 6.4) are thus important mapping targets. The possibility of localized crustal thinning associated with rifting along the northeast-striking Quaternary volcanic trend or with the Walker Lane, a major shear zone, can be evaluated by mapping the Moho reflection. Finally, the reflection character of the lower crust may correlate with several previous regional reflection studies in the Basin and Range and other extensional terranes and help constrain interpretations of its recent evolution.

Lateral discontinuities within the crystalline basement on the seismic reflection profiles will be evaluated to define the crustal structure within and adjacent to the Walker Lane in the 


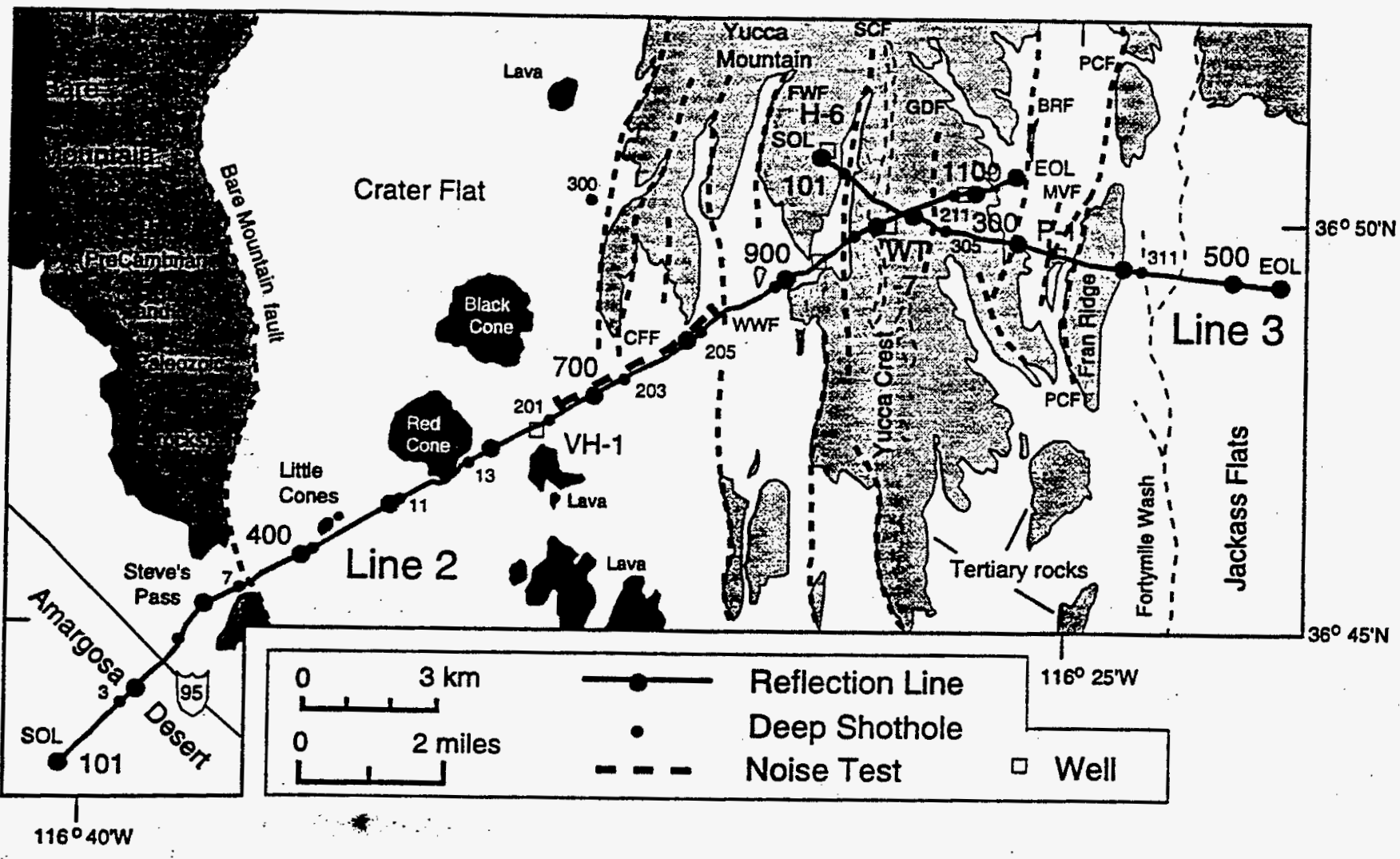

Figure 6.5. Map of the vicinity of Yucca Mountain showing location of regional seismic lines 2 and 3. Larger numbers along lines provide station numbers, and smaller numbers provide shothole locations. Darkest shaded features in Crater Flat indicate lava flows and basaltic cones. Lighter shading indicates areas of tuffaceous, silicic Tertiary rocks on and adjacent to Yucca Mountain. Bare Mountain (moderate shading to left of diagram) is composed of Precambrian and Paleozoic rocks. Selected faults are shown by dashed lines, including the Crater Flat fault (CFF), the Windy Wash fault (WWF), the Fatigue Wash fault (FWF), the Solitario Canyon fault (SCF), the Ghost Dance fault (GDF), the Bow Ridge fault (BRF), the Midway Valley fault (MWF), and the Paintbrush Canyon fault (PWF). The heavy dashed line along seismic line 2 indicates the area of noise testing for parameter recording selections. Start of line (SOL) and end of line (EOL) are labeled for both lines. Locations are provided for boreholes [shown by the symbol for "well" here] USW VH-1 (VH-1), USW H-6 (H-6), USW WT-7 (WT-7), and UE-25 p\#l (P-1) by unfilled squares. 
vicinity of the Nevada Test Site, and if one or more through-going wrench faults are found, to establish their location with respect to the Nevada Test Site and their geographic and genetic relationships to detachment faults and listric-normal faults. Reflection studies by CALCRUST in southeastern California have been extremely successful in mapping detachment surfaces within the crystalline basement. Reflections from within the crystalline basement were obtained along Line AV-1 and may represent thrust and (or) detachment faults (Brocher and others, 1993).

The style of deformation associated with the Las Vegas Valley shear zone will be examined by mapping the Proterozoic basement through the region of projected continuation in the subsurface of the Las Vegas Valley shear zone. Mapping the base of the Miocene section will provide very useful constraints on structural evolution near Yucca Mountain (Hunter and others, 1993). The structure of the unsaturated zone will be examined by characterizing the velocity structure of the near-surface layers and defining lateral variations in structure in the Nevada Test Site region. This information can be obtained from detailed analysis of first-arrivals recorded during the acquisition of the reflection data. If possible, we will trace reflections from the upper and lower carbonate aquifers, the Precambrian Pahrump Group and Noonday Dolomite, to map these aquifers and to determine their spatial continuity. Reflections from as shallow as 0.1 seconds (about $0.1 \mathrm{~km}$ depth) were obtained on Line AV-1 (Brocher and others, 1993).

Deep crustal reflection seismology using vibrator and explosion methods and supplemented by gravity and magnetic surveys, outcrops and well control should define the lateral extent, continuity, and depth of crustal features, thus constraining the location and character of the Walker Lane geologic boundary. 


\section{REFERENCES CITED}

Barbier, M.G., 1983, The Mini-Sosie Method: International Human Resources Development Corp., Boston, Massachusetts.

Brocher, T.M., and Hart, P.E., 1991, Comparison of Vibroseis and explosive source methods for deep crustal seismic reflection profiling in the Basin and Range Province: Journal of Geophysical Research, v. 96, p. 18,197-18,213.

Brocher, T.M., Carr, M.D., Fox, K.F., and Hart, P.E., 1993, Seismic reflection profiling across Tertiary extensional structures in the eastern Amargosa Desert, Basin and Range, USA, Geol. Soc. Amer. Bull., v. 105, p. 30-46, 1 plate.

Brocher, T.M., Hart, P.E., and Carle, S.F., 1990, Feasibility study of the seismic reflection method in Amargosa Desert, Nye County, Nevada: U. S. Geological Survey Open-File Report 89-133, 150 pp.

Brocher, T.M., Hart, P.E., and Hunter, W.C., 1995, Hybrid-source seismic reflection profiling across Yucca Mountain, Nevada: International Union of Geodesy and Geophysics, XXI General Assembly, Boulder, CO, Abstracts, p. A391.

Carr, W.J., 1988, Volcano-tectonic setting of Yucca Mountain and Crater Flat, southwestern Nevada, in Carr, M.D. and Yount, J.C., eds., Geologic and hydrologic investigations of a potential nuclear waste disposal site at Yucca Mountain, southern Nevada: U.S. Geological Survey Bulletin 1790, p. 35-49.

Daley, T.M., Majer, E.L., and Karageorgi, E., 1994, Combined analysis of surface reflection imaging and vertical seismic profiling at Yucca Mountain, Nevada: Lawrence Berkeley Laboratory Report LBL-36467, 44 p.

deVoogd, B., Serpa, L., Brown, L., Hauser, E., Kaufman, S., Oliver, J., Troxel, B.W., Willemin, J., and Wright, L.A., 1986, Death Valley bright spot: A mid-crustal magma body in the southern Great Basin, California?: Geology, 14, p. 64-67.

Harding, S.T., 1988, Preliminary results of high-resolution seismic-reflection surveys conducted across the Beatty and Crater Flat fault scarps, Nevada, in Carr M.D., and Yount J.C., eds., Geologic and Hydrologic Investigations of a Potential Nuclear Waste Disposal Site at Yucca Mountain, Southern Nevada: U.S. Geological Survey Bulletin 1790 , p. 121-127.

Hunter, W.C., Spengler; R.W., and Brocher, T.M., 1993, Seismic reflection profiling: essential geophysical data for Yucca Mountain, Nevada: American Nuclear Society, Proceedings of the Fourth Annual International High-Level Radioactive Waste Management Conference, Las Vegas, NV, v. 2, p. 1835-1839. 
Klemperer, S.L., 1987, A relation between continental heat-flow and the seismic reflectivity of the lower crust: J. Geophysics, 61, p. 1-11.

Klemperer, S.L., Hauge, T.A., Hauser, E.C., Oliver, J.E., and Potter, C.J., 1986, The Moho in the northern Basin and Range Province along the COCORP $40^{\circ} \mathrm{N}$ seismic reflection transect: Geological Society of America Bulletin, v. 97, p. 603-618.

McArthur, R.D., and Burkhard, N.R., 1986, Geological and geophysical investigations of Mid Valley: Lawrence Livermore Natl. Lab., UCID-20740, 92 p.

McGovern, T.F., Pankratz, L.W., and Ackermann, H.D., 1983, An evaluation of seismic reflection studies in the Yucca Mountain area, Nevada Test Site: U.S. Geological Survey Open-File Report 83-912, 57 p.

Oliver, H.W., Hardin, E.L., and Nelson, P.H., eds., 1990, Status of data, major results, and plans for geophysical activities, Yucca Mountain Project: U.S. Department of Energy, Report YMP 90-38, 191 p.

Oliver, H.W., Majer, E.L., and Spengler, R.W., 1994, Geophysical investigations of the Ghost Dance fault, Yucca Mountain, Nevada: [abs.] Geological Society of America, Cordilleran Section Meeting, Abstracts with Programs, v. 26, no. 2, p. 78.

Poulter, T.C., 1950, The Poulter seismic method of geophysical exploration: Geophysics, v. 15 , p. 181-207.

Sawyer, David A., Fleck, R.J., Lanphere, M.A., Warren, R.G., Broxton, D.E., Hudson, Mark R., 1994, Episodic caldera volcanism in the Miocene southwestern Nevada volcanic field: Revised stratigraphic framework, ${ }^{40} \mathrm{Ar} / 39 \mathrm{Ar}$ geochronology, and implications for magmatism and extension: Geological Society of America Bulletin, v. 106, p. 1304-1318.

Swadley, W.C., and Hoover, D.L., 1983, Geology of faults exposed in trenches in Crater Flat, Nye County, Nevada: U.S. Geological Survey Open-File Report 83-608, 15 p.

Swadley, W.C., Yount, J.C., and Harding, S.T., 1988, Reinterpretation of the Beatty Scarp, Nye County, Nevada, in Carr, M.D., and Yount, J.C., eds., Geologic and hydrologic investigations of a potential nuclear waste disposal site at Yucca Mountain, southern Nevada: U.S. Geological Survey Bulletin 1790, p. 113-119.

Winograd, I.J., and Thordarson, W., 1975, Hydrogeologic and hydrochemical framework, south-central Great Basin, Nevada-California, with special reference to the Nevada Test Site: U. S. Geological Survey Professional Paper, 712-C, 126 pp. 


\title{
MAJOR RESULTS OF GEOPHYSICAL INVESTIGATIONS AT YUCCA MOUNTAIN AND VICINITY, SOUTHERN NEVADA
}

\section{CHAPTER 7: TELESEISMIC INVESTIGATIONS}

\author{
By John R. Evans and Moses Smith III
}

\section{INTRODUCTION}

Teleseismic tomography is the oldest and perhaps the most robust of the methods collectively called seismic tomography. For teleseismic tomography, one uses measured properties of numerous seismic rays traversing a targeted volume in the Earth to reconstruct the three-dimensional distribution of some seismic property within that volume. Inferences can be drawn from this seismic structure to the composition and current state of the target volume. In teleseismic tomography, one uses travel times from distant earthquakes (teleseisms) to reconstruct seismic-velocity perturbations in the crust and upper mantle (Aki and others, 1977).

In this study, we performed teleseismic tomography of compressional phases recorded at permanent and portable seismographs in the Yucca Mountain, Nevada, potential waste-storage site area and region (figs. 7.1a, 7.1b). Data sets used in this study were collected in 1979-1980 (Monfort and Evans, 1982) and in 1982 (Evans and Smith, 1992). Our primary goals were to delineate any extant magma systems and to map tectonic structures that might affect a potential nuclear waste repository. These studies are directly pertinent to issues of volcanic breaching of a repository, tectonic damage to the repository block, and secondary effects related to both types of activity. This article describing status of teleseismic tomography was written in 1991; seismic tomography was not funded in later years, and as noted elsewhere in this volume, such funding constraints have limited the time frame of this and other investigations.

Teleseismic tomography is the most successful geophysical technique yet applied to delineating silicic magma chambers in the crust and mafic partial melts in the upper mantle (Iyer, 1988). Nevertheless, inferences drawn from a single seismic parameter, in this case compressional-wave velocity perturbations, are inherently ambiguous. (Many properties of the rocks can have similar seismic effects.) Hence, our results are suggestive but not conclusive. These results probably indicate the presence of a large volume of upper-mantle partial melt similar to that believed to reside beneath the eastern Snake River Plain in the wake of the Yellowstone volcanic hot spot. The melt fraction is not more than a few volume pereent but would represent a large total volume of basaltic melt. Our results also are at least permissive of heating of the middle and lower crust of Crater Flat, a region having suffered Quaternary mafic enuptions (Carr, 1988; Wells and others, 1988). Further study of both features is necessary. Lastly, our results demonstrate with good confidence that the eastern boundary of the Crater Flat basin passes through or very near the repository block. Higher-resolution studies should be performed to characterize this structure and possible associated fault-displacement and hydrologic hazards. 


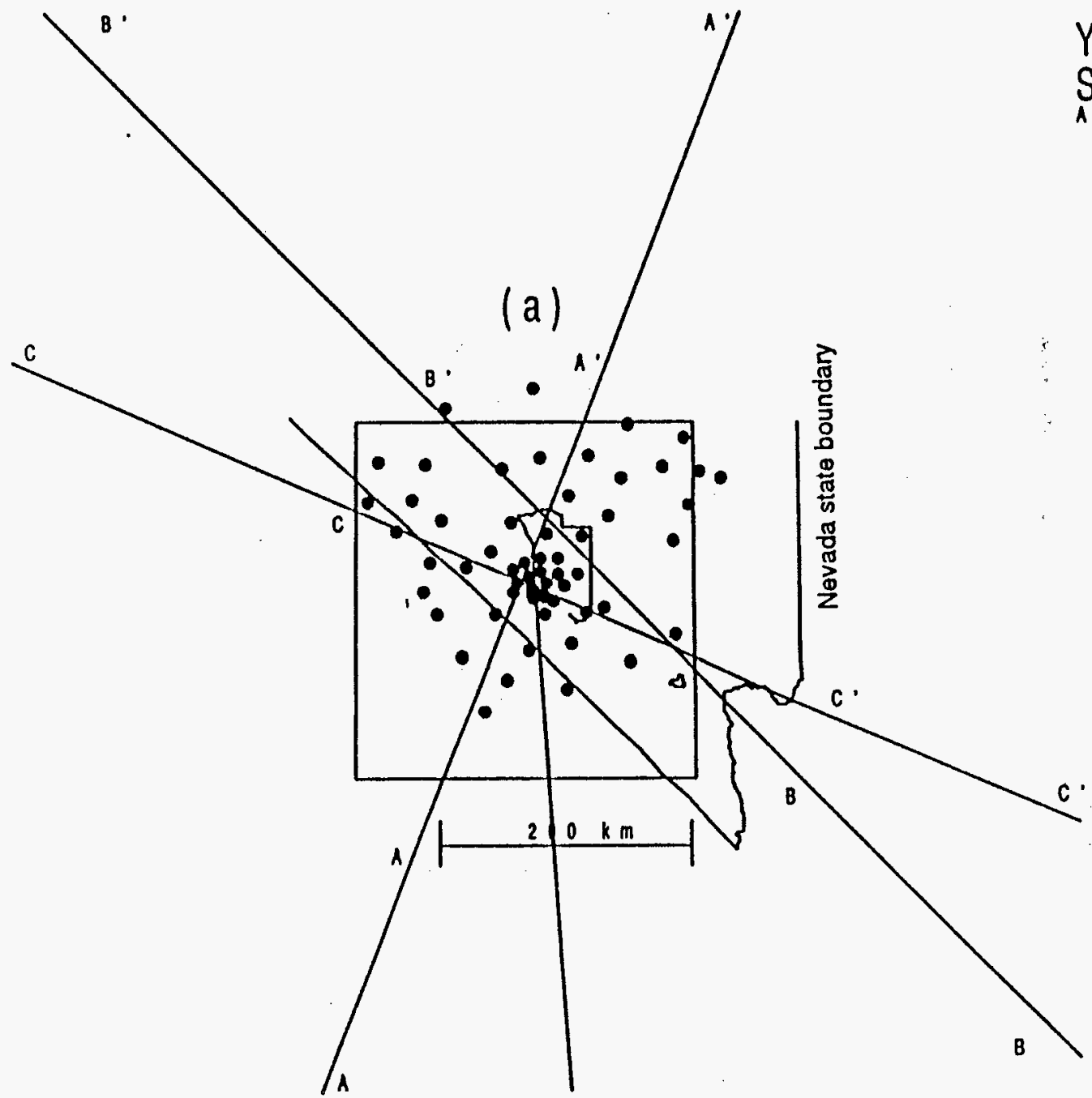

Figure 7.1a. Location map showing geographic selting, cross section lines, and seismograph stations (dots) used to generate tomograms of (a) the site region (large square) and surrounding areas of the Southern Great Basin, and (b) the site area (small rectangle) and nearby areas around Yucca Mountain. In (a) the Nevada state boundary and the NTS boundary are shown for reference. In (b) the Nevada Test Site (NTS) boundary, the known and suspected calderas of the southwestem Nevada volcanic field (Byers and others, 1989), and Fortymile Wash are shown. Cross-section letters do not correspond to specific locations, only to azimuth along the respective line. 

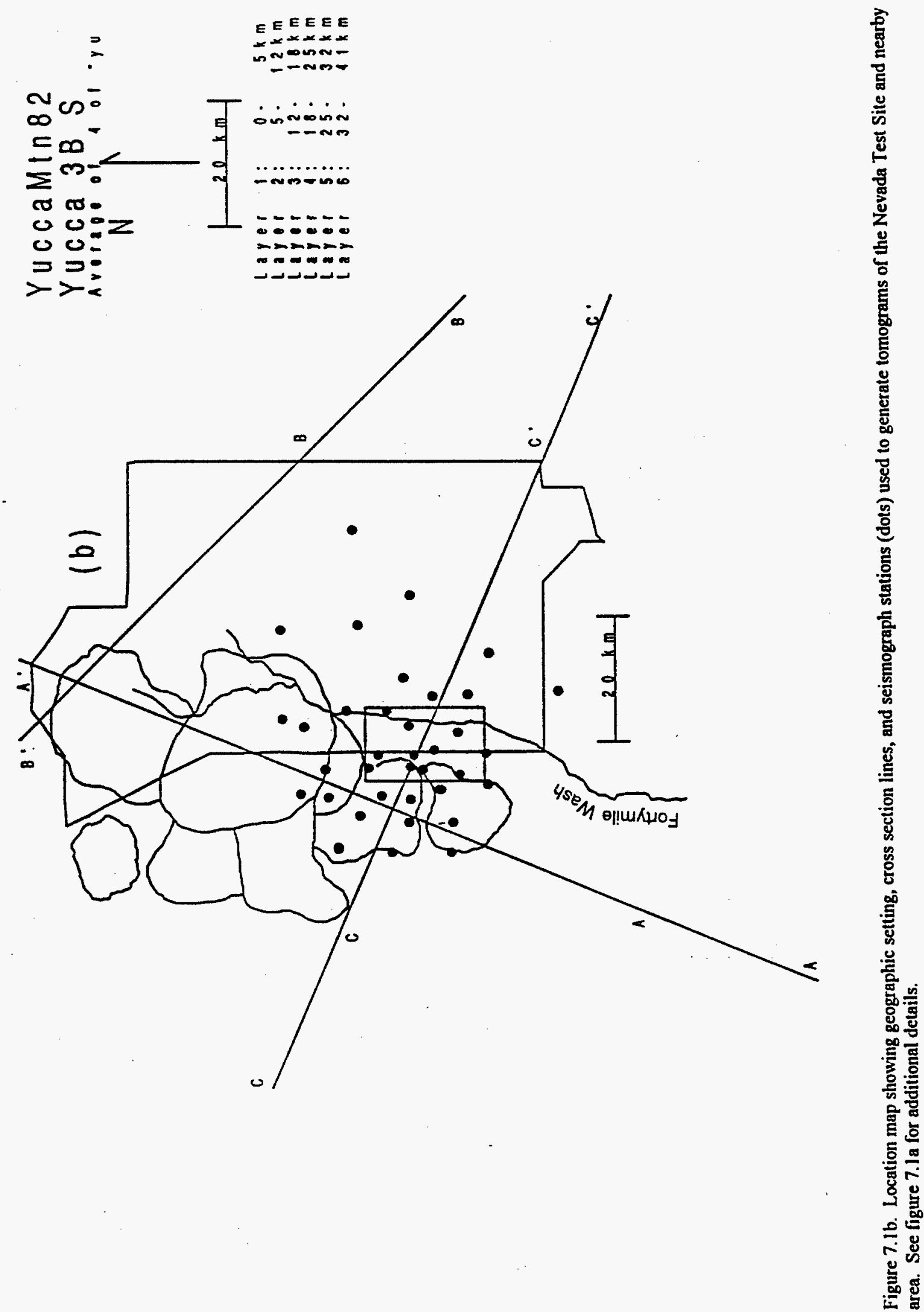
The remainder of this chapter describes the teleseismic tomography method, the type and quality of our data, the tomographic inversion results and their reliability, and inferences drawn from these results. Experiments that would reduce the ambiguity of our results are also described here.

\section{METHOD}

Teleseismic tomography is a quantitative seismic method developed by Aki, Christoffersson, and Husebye (Aki, 1977) to image three-dimensional compressional-wave velocity structure beneath two-dimensional arrays of seismographs. It is useful at crustal and upper-mantle depths. The damped least-squares inversion described by them often is called "ACH" after their initials. It is analogous to medical "CAT" scanning ("computer assisted [medical X-ray] tomography"), hence the name "tomography." With a number of elaborations (Evans and Zucca, 1988), the ACH method is employed here at two different levels of resolution.

Travel times of phases from distant earthquakes ("teleseisms") are compared to theoretical travel times computed from standard Earth models. Compressional phases are used because they are well observed with the available 1-Hz seismometers. Travel times for these phases are compared to travel times given in the tables by Herrin (1968). Though the method is quite insensitive to this choice, we use Herrin's tables because they represent a high-quality continental model biased toward the Nevada Test Site area (many test-site explosions were used in computing the model). To compute the station-to-epicenter distance ( $\Delta$, usually given in degrees of arc across the globe) and obtain hypocentral depth (needed to specify a unique theoretical travel time from the Herrin tables), hypocenters from the Preliminary Determination of Epicenters, a U.S. Geological Survey periodical listing hypocentral determinations from world-wide seismograph networks (U.S. Geological Survey, 1982) are used. The method is not demanding of precision in these hypocenters.

The difference between observed and theoretical travel times is called a travel time residual. This raw residual contains contributions from source errors (mislocations or origin-time errors in the hypocenters used), path errors (global differences between Herrin's tables and true Earth structure), and structure beneath the seismograph array itself. Isolation of the last of these is needed for use in modeling local Earth structure. Because teleseisms are much further from the seismograph array than the aperture (diameter) of the array, both source and path errors are nearly constant over the whole array and can be removed or reduced to insignificant size by subtracting some constant "reference residual" from all the raw residuals for a particular teleseism. In particular, the $\mathrm{ACH}$ inversion uses a weighted mean residual for each teleseism as that teleseism's reference residual. The resulting "relative residuals" contain significant information only about variations between the mean Earth structure and the structure actually present beneath the seismograph array. 
These relative residuals are inverted for velocity structure beneath the array in a linearized, damped least-squares inversion. The target volume beneath the seismograph array is divided into layers and the layers into blocks in a regular space-filling grid. In the first (shallowest) layer, blocks are assigned instead one per station, accounting for the facts that rays from different stations rarely cross fire at this depth and that the shallow upper crust beneath most stations contributes a "station static" highly dependent on exact station siting. The single block assigned to each station absorbs this static, more accurately modeling the Earth. The ray integral is linearized and reduced to a matrix equation. Parameter separation for the reference residual and related terms isolates the solution for velocity perturbations, which is obtained by damped least squares (Evans and Zucca, 1988). The resolution of velocity structure is limited by how many different ray directions are available. A dense "cross fire" of rays is required to locate structures accurately in three dimensions. Note that teleseismic tomography directly resolves only velocity variations about an unknown mean velocity. Relative residuals produce relative-velocity models. Lastly, we use a smoothing technique described by Evans and Zucca (1988) to reduce noise and artifacts of parameterization.

\section{DATA}

We used existing analog data from 1979-1980 (Monfort and Evans, 1982) combined with a large data set we collected in 1982 (Evans and Smith, 1992). The latter data set was processed digitally and is more precise than the earlier one; all the data were reprocessed to include GPS (Global Positioning System) station coordinates. We used data from both studies collected at the Southern Great Basin (SGB) permanent array to study large-scale regional structures to a depth of about $300 \mathrm{~km}$. To image crustal structure at much higher resolution, we used a dense array of permanent and portable seismograph stations around Yucca Mountain itself, including only the more precise 1982 data.

Using relative residuals yields one significant advantage-greatly improved arrivaltime picking accuracy. One does not need absolute arrival times, only relative arrival times. First arrivals of teleseisms are emergent and very difficult to pick to better than $0.25 \mathrm{~s}$ accuracy. However, the first cycle or so of nearly all teleseisms is highly coherent across several hundred kilometers, so one may correlate it to obtain accurate relative arrival times. The digital data from around Yucca Mountain were picked manually by a visual-coherence method on narrow-band filtered seismograms and are accurate to better than $0.05 \mathrm{~s}$ (fig. 7.2). Data from the larger regional array are accurate to about $0.1 \mathrm{~s}$ because of the older analog data (no filtering) and the larger aperture (lower phase coherence) of that array. Teleseismic events are not evenly distributed across the globe. Though the western U.S. is well situated for such work, we winnowed the data to produce ray sets more homogeneous in azimuth and incidence angle. 


\section{RESULTS}

We describe ACH models at two scales. The regional model generally confirms and extends previous work (Monfort and Evans, 1982) while the new digital data yield far more information about the middle and lower crust beneath the Yucca Mountain area than was previously available.

We first describe regional structures determined from the array (shown in fig. 7.1a) using the results of this $\mathrm{ACH}$ inversion. In the $\mathrm{ACH}$ models used to generate this smoothed model (fig. 7.3), diagonals of the resolution matrix are about 0.8 to 0.9 , and standard errors are mainly less than about $0.4 \%$ in the well-resolved central portions of the model. Hence, objects larger than two blocks across and with velocity contrasts greater than about $1.2 \%$ (fig. 7.3 ) are significant in these central areas.

The central area of the model is dominated by two large velocity anomalies. Beneath the Silent Canyon caldera and the northern part of the Nevada Test Site, a large high-velocity body is present from near the Moho to depths of about $200 \mathrm{~km}$. This object has been observed by a number of other investigators (Monfort and Evans, 1982; Spence, 1974; Minster and others, 1981; Taylor, 1983), but we provide here (fig. 7.3) the most comprehensive and well-resolved image available for this anomaly. It reaches about $3 \%$ above the mean mantle velocity (fig. 7.3b); all $\mathrm{ACH}$ results slightly damp the magnitude of anomalies, so it probably is somewhat faster than $+3 \%$. The high-velocity anomaly is approximately circular in plan.

The other well-resolved feature is a large low-velocity anomaly south and east of the high and covering a similar depth range. It is elongate in plan view (fig. 7.3a), striking east-west to northeast-southwest and reaches about $-3 \%$ in magnitude. An apparent eastnortheastern extension of this feature has been observed beneath the St. George volcanic field (Dueker and Humphreys, 1990), which is centered about $400 \mathrm{~km}$ east-northeast of Yucca Mountain, in south central Utah. Note that the low-velocity anomaly wraps around the southern part of the Nevada Test Site, abutting the Crater Flat area from below to the south and east (figs. 7.3a and 7.3c).

Lastly, there is a significant but poorly resolved high-velocity object on the southwestern edge of the model (fig. 7.3a). The anomaly is generally beneath the Funeral Mountains and Death Valley, though its depth is essentially unknown and its position only poorly known. One can speculate that this anomaly is related to the active extensional process in Death Valley, but additional data from stations west of the existing array are required to resolve this feature.

Our finer-scale models of the crust and uppermost mantle beneath the Yucca Mountain area are shown (fig. 7.4). The resolution and standard errors of these models are poorer per block than for the regional model (but the blocks are much smaller, so volumetric resolution is actually improved). Diagonal elements of the resolution matrix 


\section{Pick Accuracy}

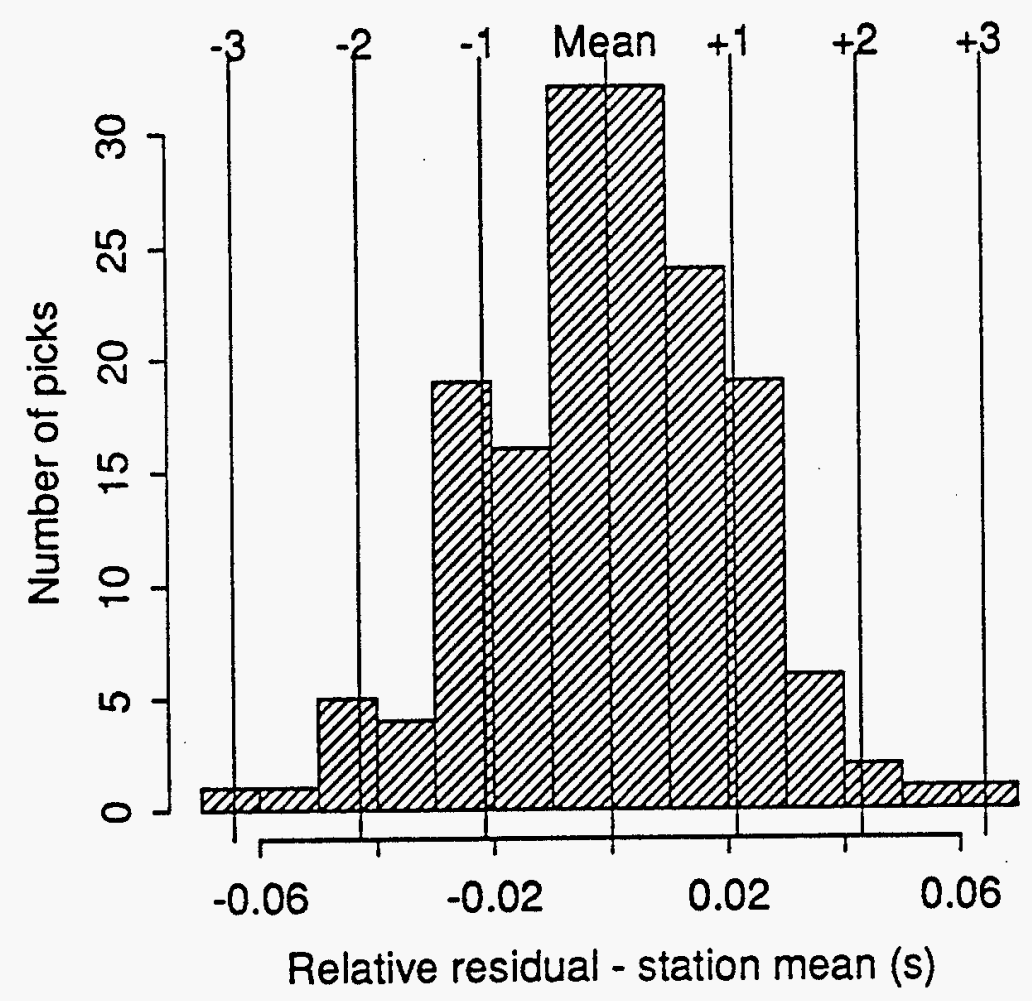

Figure 7.2. Phase pick accuracy, measured by the variation in relative residuals for a cluster of sources occupying a very small volume beneath the Gilbert Islands in the south Pacific (about $30 \times 50 \mathrm{~km}$ at $\Delta=73^{\circ}$; depths ranged from 27 to $29 \mathrm{~km}$, where determined). Since the source volume is very small, the ray paths are nearly identical. The receiver array is $30 \mathrm{~km}$ across (fig. $7.1 \mathrm{~b}$ ). The reference residual is a weighted mean, so the scatter is a reliable, maximum estimate of errors in individual picks. A total of 163 picks from 19 receivers were used, with the mean relative residual of each station removed for presentation on a common abscissa. Picks of all usable qualities were included. Vertical lines show the mean and the mean $\pm 1 \sigma . \pm 2 \sigma$. and $\pm 3 \sigma$ (standard deviation) range of the combined data. 
(a)

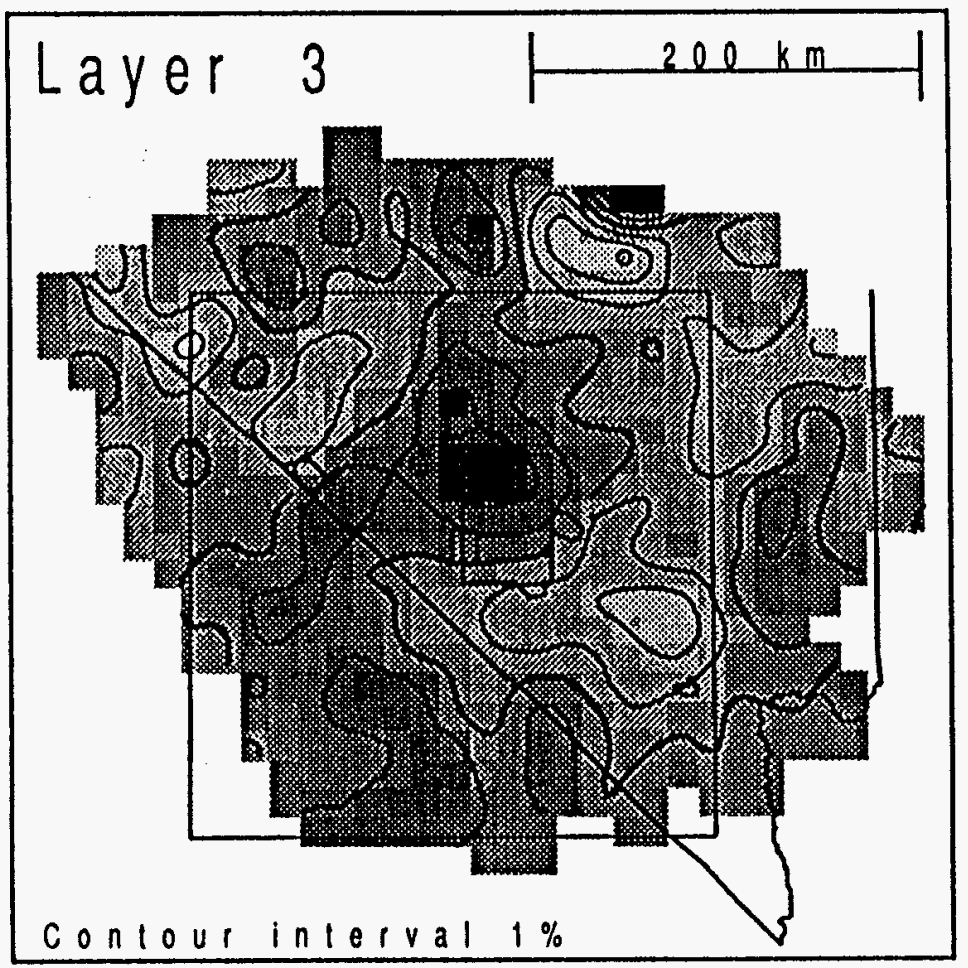

\section{Velocity}

$-3 \%-$

SIOW

Me a $n$

Fast

$+3 \%$

Figure 7.3a. ACH tomographic inversion results for data from the stations shown in figure 7.1a. (a) Plan view for a layer 76- to 120-km-deep in the upper mantle (layer 3, the second mantle layer). (b) cross section B-B'; and (c) cross section C-C'. Cross section locations are shown in figure 7.la. There is no vertical exaggeration in the cross sections; distance scales are the same on all plots. Velocity perturbations about the mean layer velocity are shown both by gray scale $( \pm 3 \%)$ and contours ( $1 \%$ interval). Geographic information on (a) is the same as in figure 7.1a, except that the potential site area is also shown in this figure. Positions along the cross sections are shown by their intersections with the Nevada Test Site and either (b) Silent Canyon caldera (SC) or (c) the possible caldera beneath northem Crater Flat (CF). The crust is layer one of the cross sections (triangles) and the Earth's surface is shown approximately by the black line at the tops of the triangles. 


\section{YuccaMtn 82 \\ $S G B 2 B S$ \\ Average ol 4 of "sgb 2 a sal" \\ Velocity}

$\begin{array}{ccc}0.00 & 0.00\end{array}$

(b)

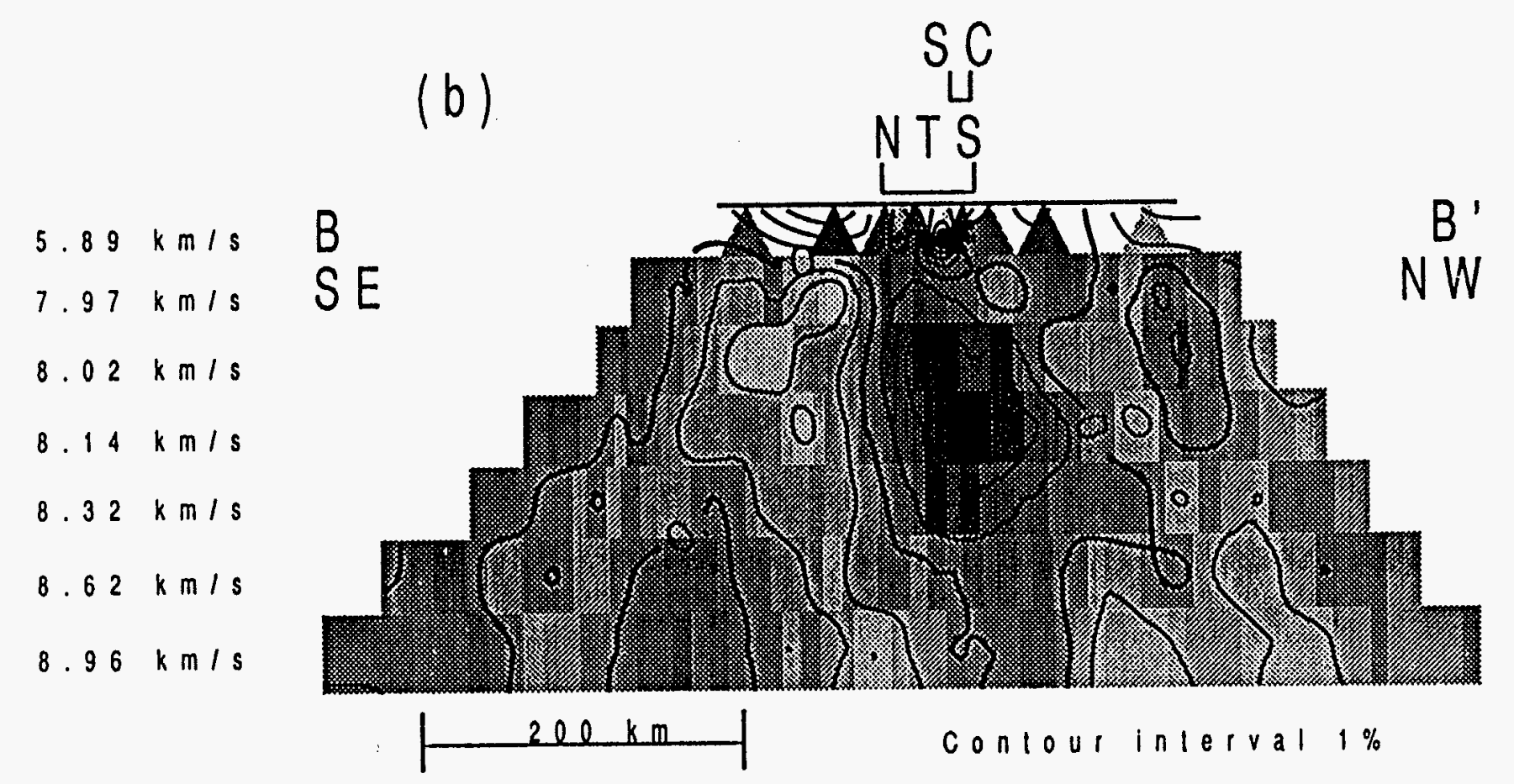

Figure. 7.3b. Cross section B-B" from figure 7.3a. See figure 7.3a for additional details. 


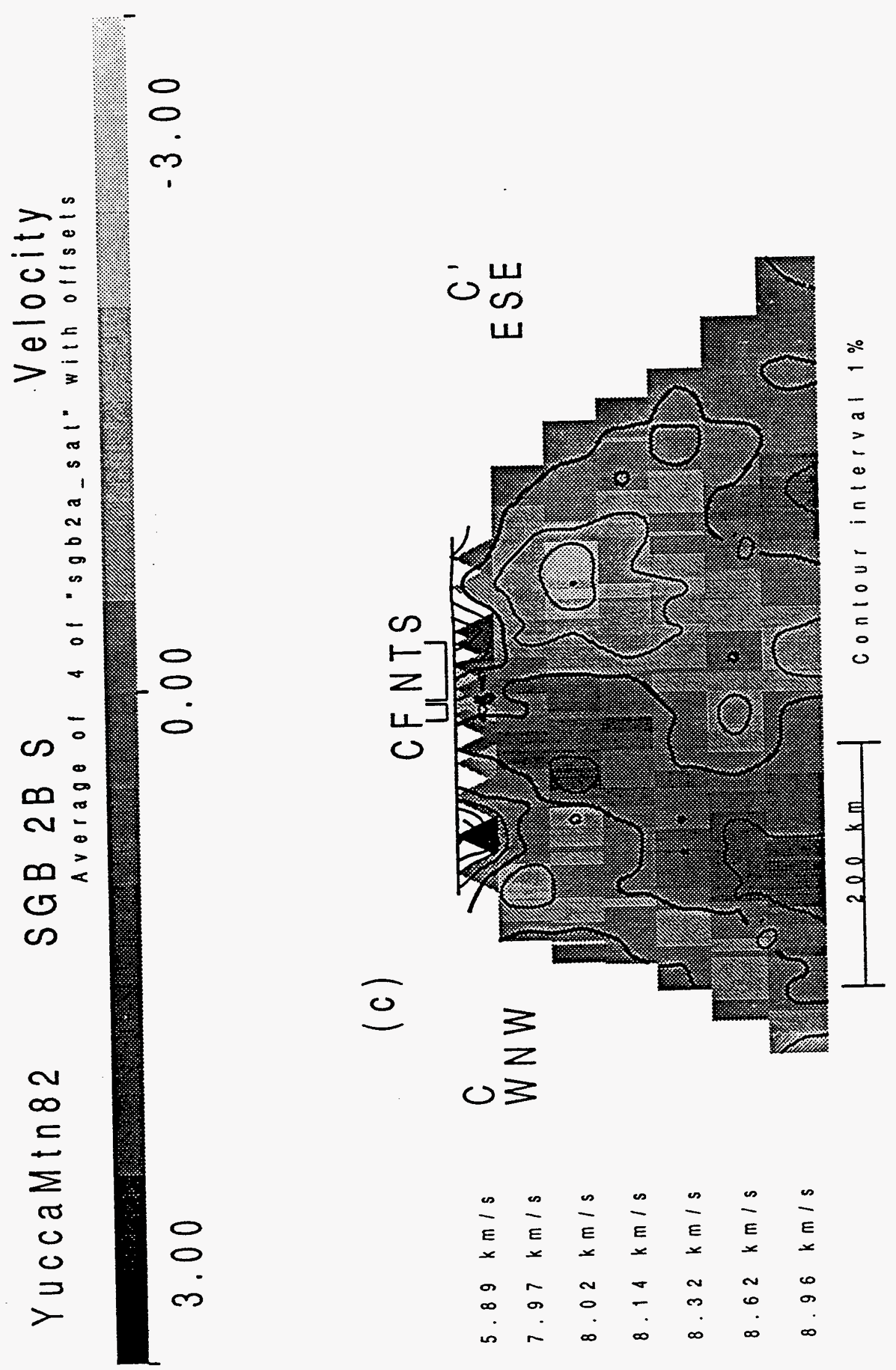

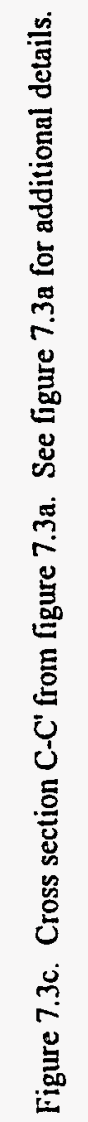




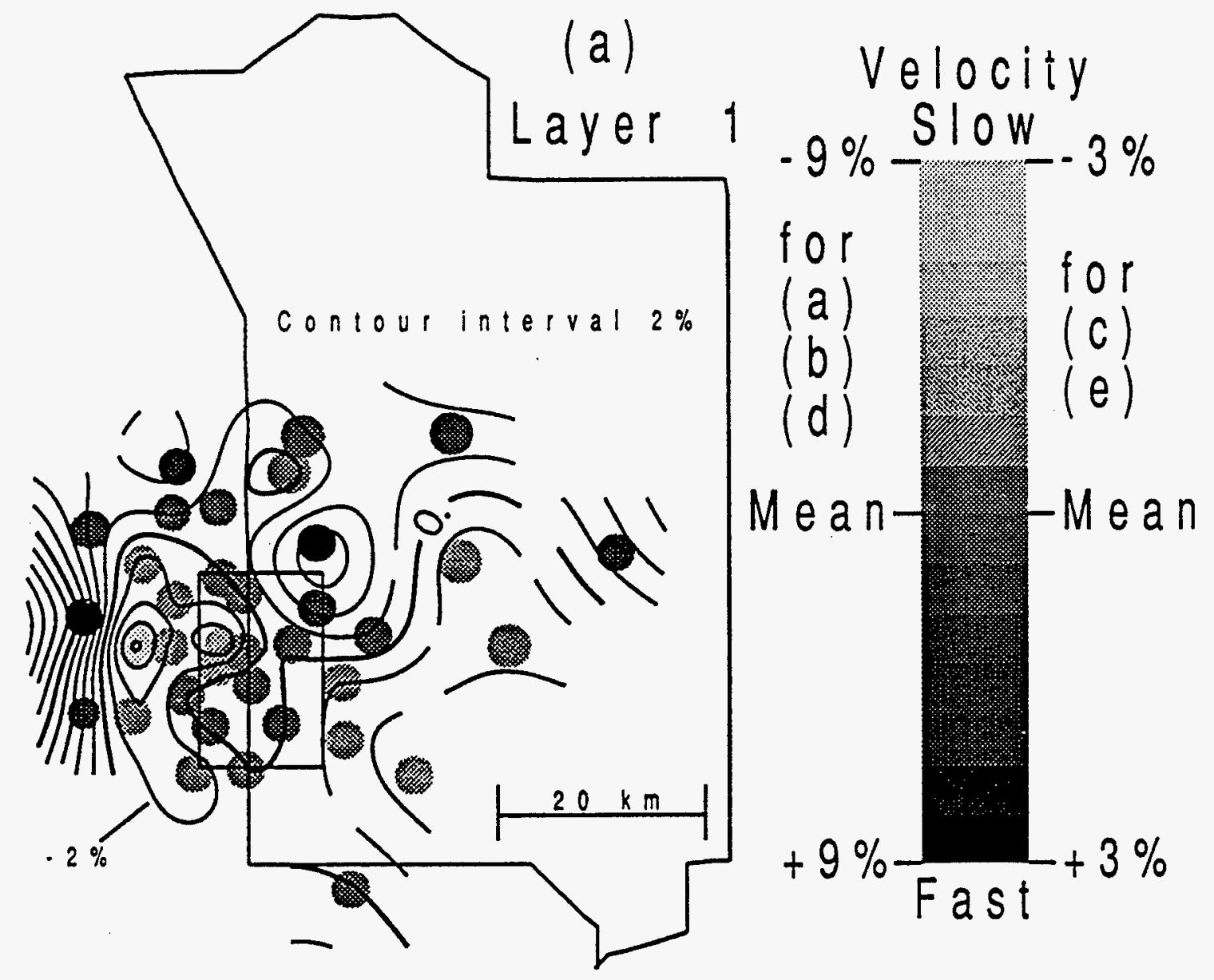

Figure 7.4a. $\mathrm{ACH}$ velocity models for data from the stations in figure 7.1b. (a) Unstripped inversion for layer one (from the surface to depth of $4.9 \mathrm{~km}$ ). Calderas and Fortymile Wash (fig. 7.1b) are deleted for clarity. There is one "block" (dot) for each seismograph. Cross section A-A' (fig. 7.lb) was used for unstripped (b) and stripped (c) models. Cross section $C-C^{\prime}$ (fig. 7.1b) was used in unstripped (d) and stripped (e) models. Cross section locations are shown in figure 7.1b. There is no vertical exaggeration; distance scales are the same as in (a). Positions along the cross sections are shown by their intersections with the Nevada Test Site, Timber Mountain caldera (Timber), and the possible southern (SCF) and northern (NCF) Crater Flat calderas. 


\section{YuccaMtn 82 \\ Yucca $2 B$ S \\ Velocity \\ Averago 014 ol "yuccara-sal" wilh ollse}

9.00

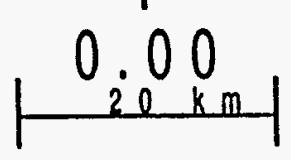

.9 .00

$A^{\prime} N 22 E$

点
$4.43 \mathrm{~km} / \mathrm{s}$
$6.01 \mathrm{~km} / \mathrm{s}$
$6.06 \mathrm{~km} / \mathrm{s}$
$6.42 \mathrm{~km} / \mathrm{s}$
$6.43 \mathrm{~km} / \mathrm{s}$
$7.95 \mathrm{~km} / \mathrm{s}$

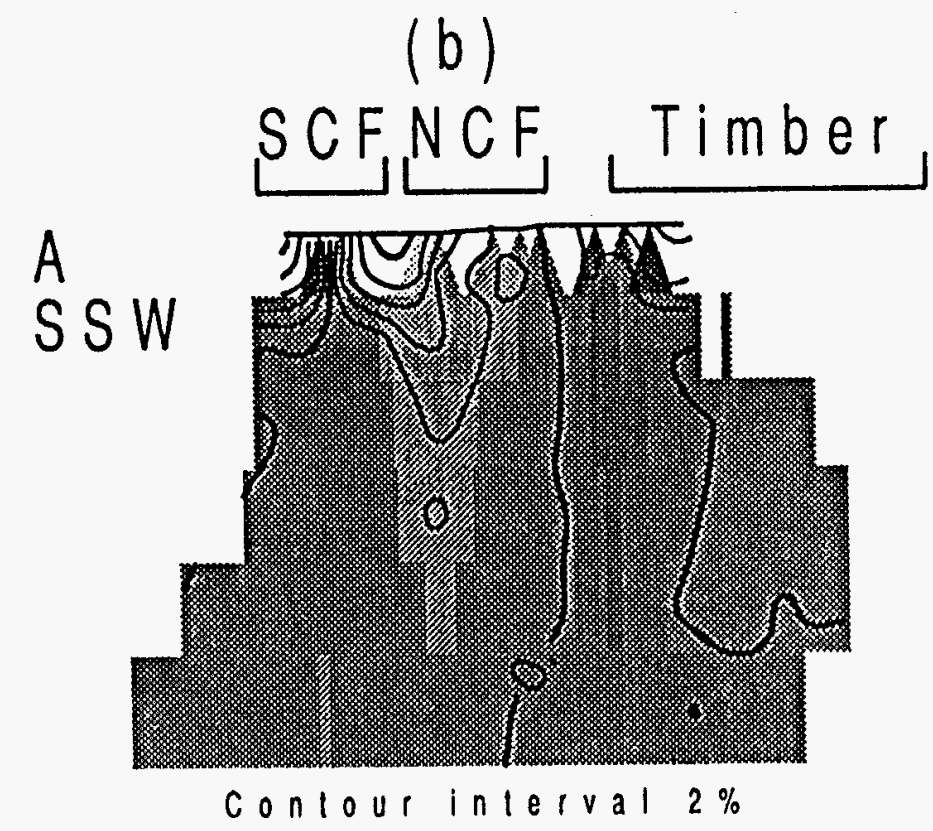

Figure 7.4b. See figure 7.4a for additional details. 


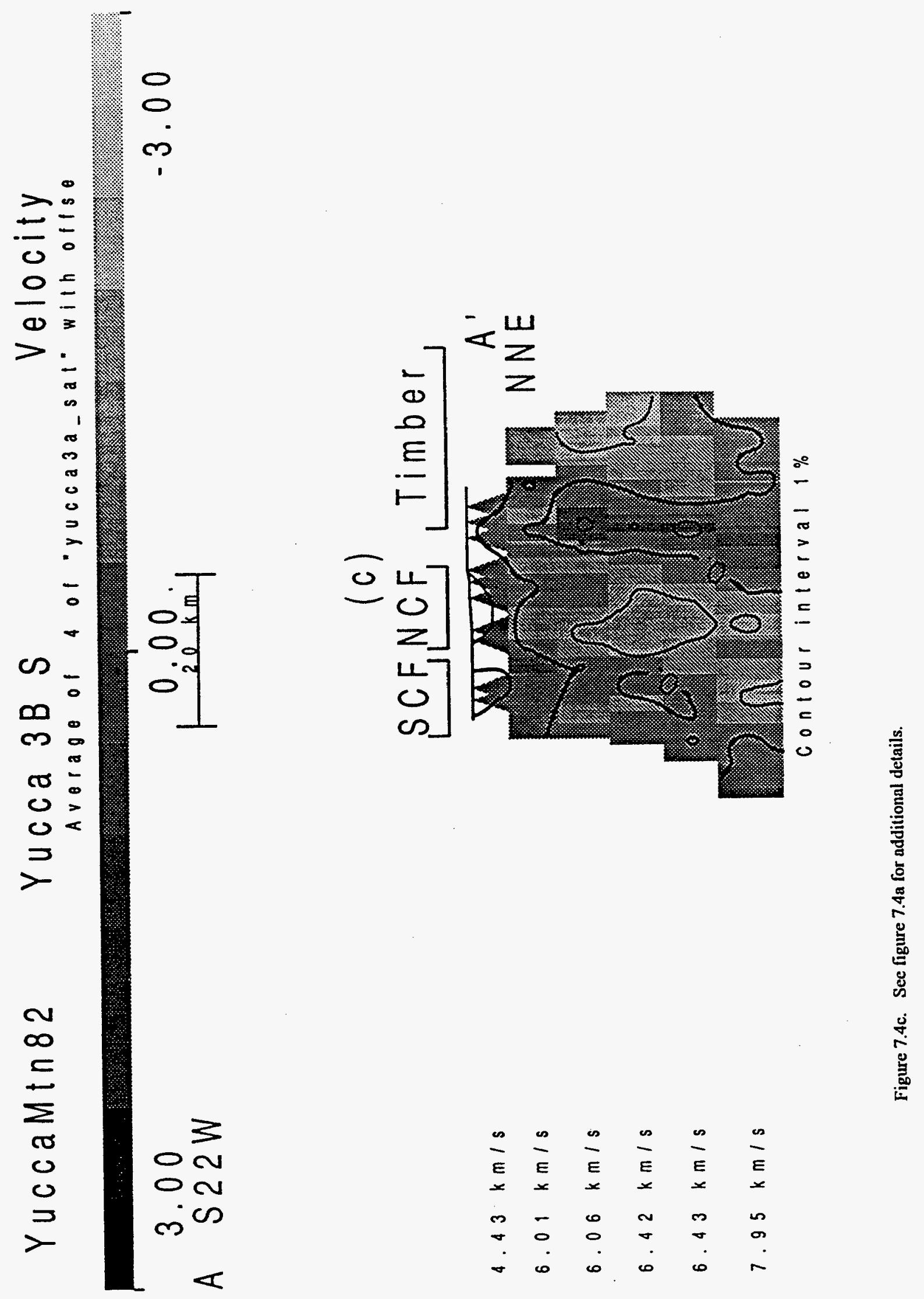



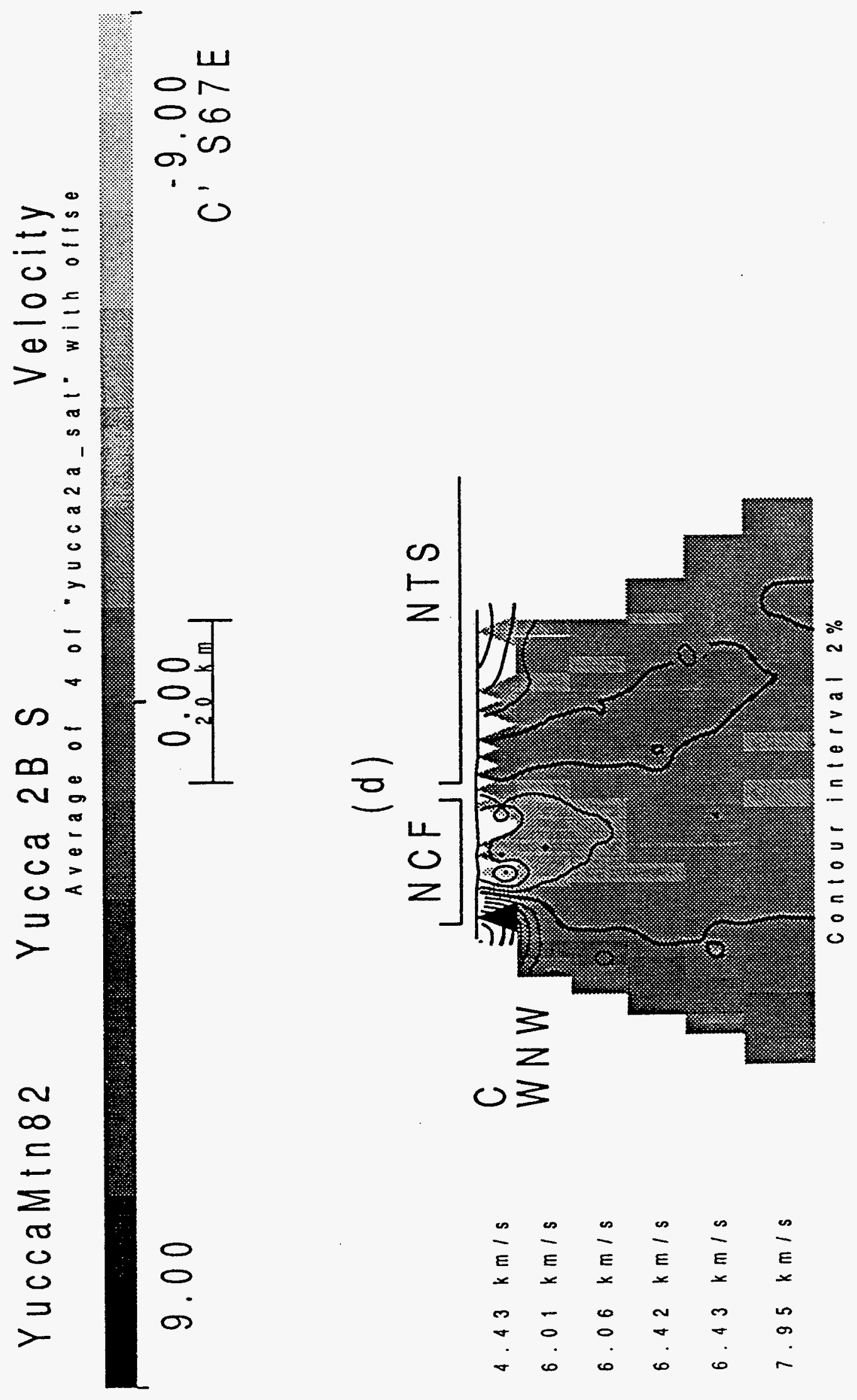

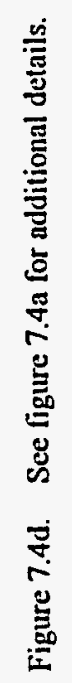

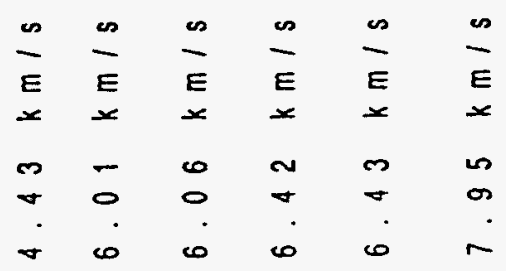


YuccaMtn 82

Yucca $3 B$ S

Velocity

Average of 4 of "yuccasa_sat" with oflse

C $\stackrel{3}{\mathrm{~N}} 67 \mathrm{OW}$

$\mid \begin{array}{lll}0.0 & 0 \\ 20 & 8 \times 1\end{array}$

$-3.00$
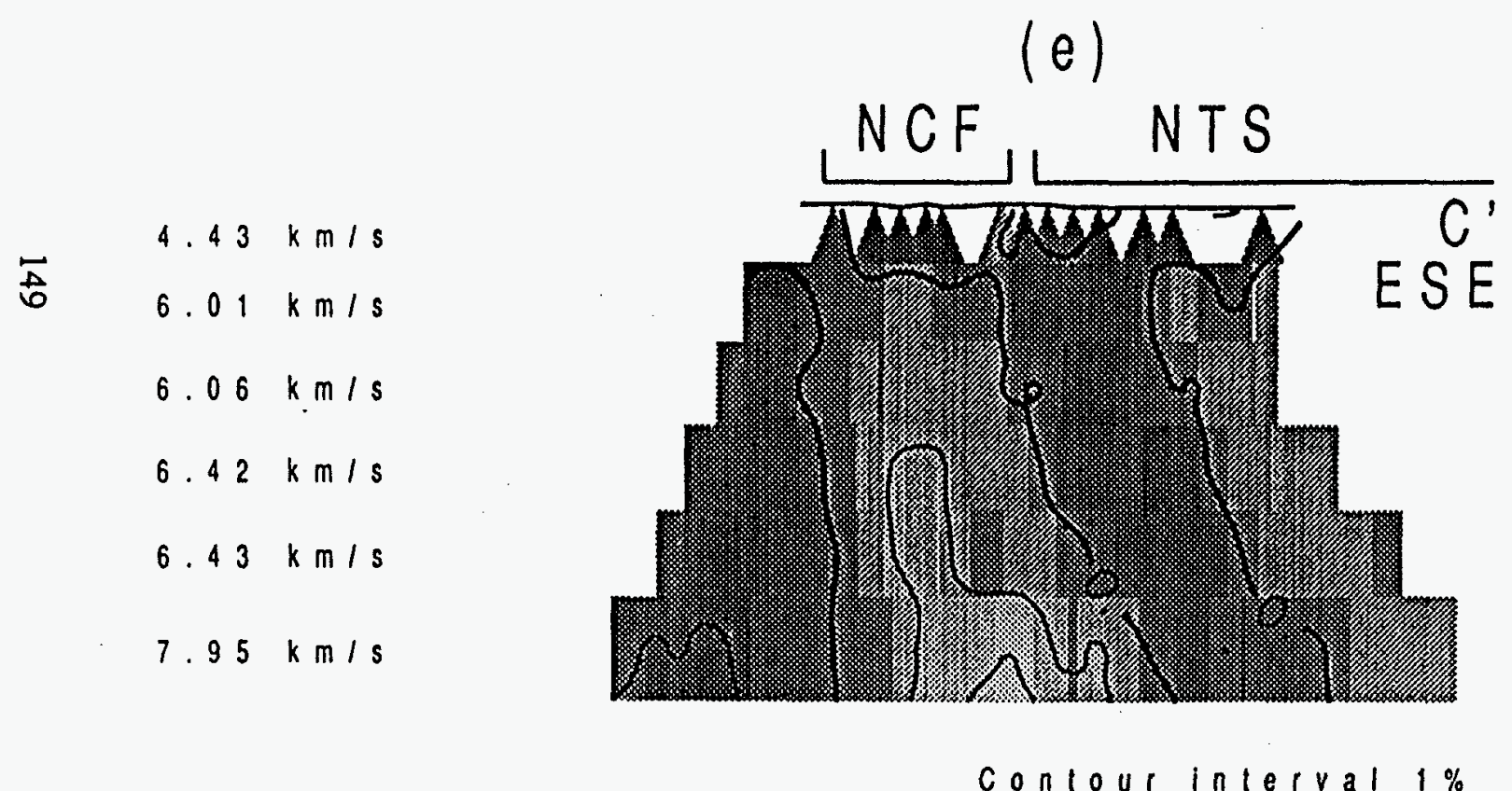

Figure 7.4e. See figure 7.4a for additional details. 
range from 0.3 to 0.4 for blocks in the central parts of the model, higher in the first layer, while standard errors are about $0.5 \%$. Hence, to be significant an object must be two or three layers high and two blocks wide (in fig. 7.4) and must have a velocity contrast of at least $1.5 \%(3 \sigma)$. Therefore, significantly better spatial resolving power is available in this model than in the regional model, in spite of poorer resolution characteristics for the individual contributing blocks (fig. 7.4). We can distinguish two or three crustal levels and horizontal areas as small as about $4 \mathrm{~km}$ (compared to only one crustal level and about 25 $\mathrm{km}$ horizontally in figure 7.3 ).

Two clear conclusions can be drawn from these figures. First, there is no evidence of a large 5 to $10 \%$ low-velocity feature in the middle crust, so this region is not outwardly similar to the great majority of active, continental, silicic volcanoes similarly studied (Iyer, 1988). Second, the low-velocity tuff, breccia flows, and sediment filling the Crater Flat depression dominates the shallow crustal structure. There is a strong positive correlation between this teleseismic signature and the isostatic gravity anomaly for the same region (Evans and Oliver, 1987), suggesting a simple relationship between these velocities and the depth to Paleozoic basement.

There are strong high velocity perturbations along Bare Mountain, where Paleozoic basement rocks crop out, and weaker velocity highs beneath Yucca Mountain and other areas thought to be underlain by basement highs (Hoffman and Mooney, 1984; Snyder and Carr, 1982). The Crater Flat depression yields a prominent low west of the site area but also entering the site area in the north. This incursion is well represented by the $-2 \%$ contour (fig. 7.4a) and occurs somewhere between our stations in Solitario Canyon and west of Fortymile Wash along the road to the summit of Yucca Mountain. These stations are about $3.6 \mathrm{~km}$ apart, spanning the summit block; the eastern boundary of the Crater Flat depression falls between them. It probably is not very near the Solitario Canyon site because the boundary likely dips west and teleseismic rays at this depth are very steep. Hence, a significant depth of low-velocity material directly underlies the Solitario Canyon station.

Because the strong low-velocity anomaly of Crater Flat basin smears downward into the crust, we have used an iterative shallow-structure stripping method to remove the effects of basin fill. This technique may overcorrect, removing some of the deeper structure as well, but it yields a reliable minimum-perturbation estimate for middle and lower crustal anomalies (Dawson and others, 1990). In this "stripped" model (figs. 7.4c and $7.4 \mathrm{e}$ ), a weak but significant low-velocity anomaly remains in the middle and lower crust beneath Crater Flat. Its velocity is 2 to $3 \%$ lower than the velocity under Yucca Mountain, the only other adequately resolved part of the model. The Crater Flat low spans at least the lower third of the crust and probably extends up into the middle crust and down into the upper mantle, where it may bend slightly eastward, toward the larger upper mantle low-velocity anomaly of the regional model. This middle- to lower-crust low-velocity anomaly is not an artifact of the inversion or of the upper-crustal basin. 


\section{DISCUSSION}

Yucca Mountain is a low range of gently east-dipping fault blocks bounded on the west by steeper slopes caused by en echelon normal faulting. It is composed of Miocene silicic welded ash-flow tuffs, primarily tuffs of the Paintbrush Group of the Timber Mountain-Oasis Valley caldera complex. These tuffs overlie older Miocene tuffs from various calderas in the region, and the older tuffs in turn rest on Paleozoic bedrock, mainly carbonate rocks and some argillite. Yucca Mountain is flanked on the east by Jackass Flats, a depression thinly covered by the tuff, and on the west by Crater Flat, a deeper basin filled with tuff, breccia flows, and sedimentary deposits. Relatively young mafic lavas are present west, southwest, and south of Yucca Mountain, and possibly to the southeast as well. They are in three age groups, about $3.8 \mathrm{Ma}, 1.2 \mathrm{Ma}$, and younger than about $0.3 \mathrm{Ma}$ (Carr, 1988). The youngest of these may have been active as recently as the middle Holocene (Wells and others, 1988).

The Crater Flat depression has been interpreted in various ways. Carr considers it a pair of Miocene calderas or similar volcano-tectonic collapse features (Carr, 1988). Hamilton, for example, believes that it is more likely to be a sector graben or some noncaldera structure in a detachment-fault setting (Hamilton, 1988). Our teleseismic tomography sheds some light on this discussion in that we observe a deep crustal lowvelocity anomaly beneath Crater Flat-a structure that is somewhat easier to reconcile with the caldera interpretation, simply because volcanism probably is a deeper-seated and less wide-spread phenomenon than the large, broad uplifts associated with detachment faulting.

The site area lies in the Walker Lane belt, a region of complex tectonism. Stewart defines the Walker Lane belt as a "broad northwest-trending zone of diverse topography and strike-slip faulting" between the Sierra Nevada and the northeast part of the Basin and Range (Stewart, 1988). The Las Vegas shear zone is one such strike-slip fault. Yucca Mountain lies west of the junction between this right-lateral shear zone and the northeaststriking left-lateral faults of the Spotted Range-Mine Mountain section of the Walker Lane belt. This position may provide a concentration of structurally controlled (extensional) basaltic eruption pathways, a possibility that influences interpretations given below.

If the high-velocity upper mantle anomaly beneath the Silent Canyon caldera was the heat source for Southwestern Nevada Volcanic Field volcanism, then this system appears to have no viable heat source any longer. Gans et al (1989) relate regions of major detachment extension in the Basin and Range province to such periods of intense volcanism in the same areas. They believe that the onset of volcanism systematically predates extension and that volcanism occurs in response to a large influx of mafic magma from the upper mantle. Our results support such a model, given our evidence of significant uppermantle involvement in the Timber Mountain-Silent Canyon caldera complex. The depth of this upper-mantle involvement, however, compares to that seen beneath hot spots and not to most continental volcanic systems. Hence, the volume and persistence of volcanism in the Timber Mountain-Silent Canyon caldera complex may be due to some preheating of the lithosphere by an underlying source (a weak or transient plume or radiogenic isotope 
concentration, for example) locally augmenting decompression melting and associated volcanism of the Basin and Range.

The regional models also reveal a large volume of low compressional-velocity upper mantle, interpreted as possible partial melt on the order of 3 volume percent. To produce such melt, a subsolidus temperature increase of about 500 to $600^{\circ} \mathrm{C}$ would be required in mantle-representative samples "dunite $1675^{\prime \prime}$ and "peridotite 475" (Kern, 1982) which would be enough to melt the rocks anyway. Dueker and Humphreys (1990) show that this low-velocity anomaly extends east-northeast beyond the southern Great Basin seismic network into central Utah and the St. George volcanic field. Hence, it forms a track subparallel to the hot-spot vector with volcanic activity at both ends. It may be a weak hot-spot trace, a deep Proterozoic plate structure (a composition or volatile-content contrast), a mantle convection roll, or an effect arising from fragmentation of old subducted plates. The low may well be the source volume for Quaternary basaltic eruptions that have occurred near the site area, just as the similar anomaly beneath the eastern Snake River Plain is the likely source of continuing basaltic volcanism there (Evans, 1982). Clearly, however, any hot spot influencing this region is far weaker than Yellowstone, since there is far less surface volcanism.

Though the weakness of this low-velocity anomaly is permissive of subsolidus interpretations, the existence of active volcanism at both ends argues for a partial-melt interpretation, whether hot spot or otherwise. Basaltic volcanism appears to be strongly controlled by crustal structure in continental settings. The two places where active volcanism overlies the upper-mantle low are the Walker Lane belt and the Wasatch front, complex and active regions that may provide efficient melt pathways to the surface.

At finer scales, evidence that the east edge of the Crater Flat basin falls near or inside the repository block merits further evaluation. This structure may be a caldera ring fracture, a caldera landslide scallop fault, or a normal fault at a horst beneath the site. Stock et al. (1985) measured stresses at Yucca Mountain using hydrofracture methods and found a least principal stress oriented $\mathrm{N} 65^{\circ} \mathrm{W}$. They also showed that Yucca Mountain is near the stress limit that can cause slip on favorably oriented preexisting faults. Although other north-striking faults are present in the area and exhibit Quaternary reactivation of Miocene structures, reactivation of the Crater Flat boundary should be considered in faultrupture and hydrologic-hazard evaluations. More precise characterization of the boundary structure may be provided by a number of techniques, including active-source highresolution seismic tomography (Evans and Zucca, 1988).

Mid-crustal silicic magma chambers $4 \mathrm{~km}$ across and larger probably can be ruled out within $10 \mathrm{~km}$ of the repository block. However, the weak middle and lower crustal low-velocity anomaly beneath Crater Flat is significant. It may be caused by many phenomena, including piston-like caldera collapse juxtaposing middle- and lower-crustal rocks, alteration by Miocene volcanism, or crustal heating, possibly related to recent basaltic activity. It is quite similar to the Mineral Mountains anomaly in Utah, which lies beneath vents of Quaternary rhyolite flows and near the Roosevelt Hot Springs geothermal 
area (Robinson and Iyer, 1979). This similarity supports the crustal heating hypothesis at Crater Flat.

\section{CONCLUSIONS}

Regional teleseismic tomography reveals a deep seated high-velocity anomaly beneath, and probably associated with, the Miocene Southwestern Nevada Volcanic Field. If so associated, this system is no longer active, and its former mantle heat source has cooled. However an adjacent low-velocity anomaly striking north-northeast from the southern part of the Nevada Test Site may represent a large volume of small-fraction partial melt, possibly even a weak hot spot track. It is overlain at both ends by areas characterized by Quaternary volcanism: Crater Flat and the St. George volcanic field. These may be leaks of the melt fraction permitted by complex active tectonic settings in these locations.

The crust shows no evidence of a large, well-developed silicic magma chamber, but a weak low-velocity feature beneath Crater Flat may represent crustal heating beneath that basin, among other possibilities. The east boundary of the Crater Flat basin, as delineated by both teleseismic and gravity data, clearly falls inside or very near the repository block and may represent a faulting hazard to a potential repository.

Additional teleseismic studies are warranted to reduce the ambiguity of these results and to better resolve crustal features. In particular, fine-scale teleseismic tomography studies of shear-wave velocity and compressional-wave attenuation would sharply narrow the list of possible interpretations of the Crater Flat anomaly. Local-earthquake tomography using existing data would help resolve structural relationships between the Crater Flat anomaly and the basin of Crater Flat, but this approach cannot reach deeper than about the deepest earthquakes, roughly the upper third of the crust. Lastly, regional shear-wave-velocity and compressional-wave-attenuation teleseismic tomography should demonstrate reliably whether the upper-mantle low represents a partial melt. This piece of information is critical to volcanic hazards assessments since partial melt would imply a large heat source for any ongoing volcanism in the Yucca Mountain area. 


\section{REFERENCES CITED}

Aki, K., Christoffersson, A., and Husebye, E., 1977, Determination of the three-dimensional seismic structure of the lithosphere: Journal of Geophysical Research, v. 82, p, 277-296.

Byers, F.M., Jr., Carr, W.J., and Orkild, P.P., 1989, volcanic centers of southwestern Nevada: evolution of understanding, 1960-1988: Journal of Geophysical Research, v. 94, p. 59085924.

Carr, W. J., 1988, Volcano-tectonic setting of Yucca Mountain and Crater Flat, southwestern Nevada, in Carr, M.D., and Yount, J.C., eds., Geologic and hydrologic investigations of a potential nuclear waste disposal site at Yucca Mountain, southern Nevada: U.S. Geological Survey Bulletin 1790, p. 35-49.

Dawson, P.B., Evans, J.R., and Iyer, H.M., 1990, Teleseismic tomography of the compressional-wave velocity structure beneath the Long Valley region, California: Journal of Geophysical Research, v. 95, p. 11,021-11,050.

Dueker, K., and Humphreys, E., 1990, Upper-mantle velocity structure of the Great Basin: Geophysical Research Letters, v. 17, p. 1327-1330.

Evans, J.R., 1982, Compressional wave velocity structure of the upper $350 \mathrm{~km}$ under the eastern Snake River Plain near Rexburg, Idaho: Journal of Geophysical Research, v. 87, p. $2654-2670$.

Evans, John R., and Oliver, H. W., 1987, Comparison of Timber Mountain caldera complex, Nevada, with Yellowstone: Speculations on mechanism: Abstract Volume, Hawaii Symposium on How Volcanoes Work, Hawaiian Volcano Observatory, Hilo, Hawaii, p. 67.

Evans, J.R., and Smith, Moses, III, 1992, Teleseismic tomography of the Yucca Mountain region: volcanism and tectonism: American Nuclear Society, Proceedings of the Third Annual International Conference on High-Level Radioactive Waste Management, v. 2, p. 2372-2380.

Evans, J.R., and Zucca, J.J., 1988, Active high-resolution seismic tomography of compressional-wave velocity and attenuation structure at Medicine Lake Volcano, northern California Cascade Range: Journal of Geophysical Research, v. 93, p. 15,01615,036 .

Gans, P.B., Mahood, G.A., and Schermer, E., 1989, Synextensional magmatism in the Basin and Range province; a case study from the eastern Great Basin: Geological Society of America Special Paper 133. 
Hamilton, W., 1988, Detachment faulting in the Death Valley region, California and Nevada, in Carr, M.D., and Yount, J.C., eds., Geologic and hydrologic investigations of a potential nuclear waste disposal site at Yucca Mountain, southern Nevada: U.S. Geological Survey Bulletin 1790, p. 51-85.

Herrin, E., 1968, 1986 seismological tables for P phases: Bulletin of Seismological Society of America, v. 58, p. 1193-1241.

Hoffman, L. R., and Mooney, Walter D., 1984, A seismic study of Yucca Mountain and vicinity, southern Nevada; data report and preliminary results: U.S. Geological Survey Open-file Report, 83- 588, $50 \mathrm{pp}$.

Iyer, H.M., 1988, Seismological detection and delineation of magma chambers beneath intraplate volcanic centers in western U.S.A., in King, C.-Y., and Scarpa, R., eds., Modeling of Volcanic Processes, R., Friedr. Vieweg und Sohn, Wiesbaden, p. 1-56.

Kern, H., 1982, P- and S-wave velocities in crustal and mantle rocks under the simultaneous action of high confining pressure and high temperature and the effect of the rock microstructure, in Schreyer, W., editor, High-Pressure Researches in Geoscience, E. Schweizerbart'sche Verlagsbuchhandlung, Stuttgart, p. 13-45.

Minster, J.B., Savino, J.M., Rodi, W.L., Masso, J.F., and Jordan, T.H., 1981, Threedimensional velocity structure of the crust and upper mantle beneath the Nevada Test Site: EOS, Transactions American Geophysical Union, v. 62, p. 972.

Monfort, M.E., and Evans, J.R., 1982, Three-dimensional modeling of the Nevada Test Site and vicinity from teleseismic P-wave residuals: U.S. Geological Survey Open-file Report $82-409$.

Robinson, R., and Iyer, H.M., 1979, Evidence from teleseismic P-wave observations for a low-velocity body under the Roosevelt Hot Springs geothermal area, Utah: Trans. Geothermal. Resource. Coun., v. 3, p. 585.

Snyder, D. B., and Carr, W. J., 1982, Preliminary results of gravity investigations at Yucca Mountain and vicinity, southern Nye County, Nevada: U.S. Geological Survey Open-file Report 82-701, 36 pp.

Spence, W., 1974, P-wave residual differences and inferences on an upper mantle source for the Silent Canyon Volcanic Centre, southern Great Basin: Geophysical Journal of the Royal Astronomical Society, v. 38, p. 505-524.

Stewart, J.H., 1988, Tectonics of the Walker Lane belt, western Great Basin: Mesozoic and Cenozoic deformation in a zone of shear, in Ernst, W.G., ed., Metamorphism and crustal evolution of the western United States, Rubey Volume VI, Prentice Hall, Englewood Cliffs, New Jersey, p. 683-713. 
Stock, J.M., Healy, J.H., Hickman, S.H., and Zoback, M.D., 1985, Hydraulic fracturing stress measurements at Yucca Mountain, Nevada, and relationship to the regional stress field: Journal of Geophysical Research, v. 90, p. 8691-8706.

Taylor, S.R., 1983, Upper-mantle velocity structure of the Great Basin: Journal of Geophysical Research, v. 88, p. 2220-2232.

U.S. Geological Survey, 1982, Preliminary Determination of Epicenters, Monthly Listing: U.S. Government Printing Office, Washington, D.C.

Wells, S.G., McFadden, L., Renault, R., Turrin, B. D., and Crowe, B. M., 1988, A geomorphic assessment of Quaternary volcanism in the Yucca Mountain area, Nevada Test Site, Southern Nevada [abs.]: Geological Society of America, Cordilleran Section Meetings, v. 20, p. 242. 


\section{MAJOR RESULTS OF GEOPHYSICAL INVESTIGATIONS AT YUCCA MOUNTAIN AND VICINITY, SOUTHERN NEVADA}

\section{CHAPTER 8: REGIONAL THERMAL SETTING}

By J.H. Sass, W.W. Dudley, Jr., and Arthur H. Lachenbruch

\section{INTRODUCTION}

Among the factors to be evaluated in assessing the suitability of the Yucca Mountain area as a potential repository for high-level nuclear waste are the tectonic setting and the regional and local hydrologic regimes. The most important tectonic factors, seismic and volcanic hazards, have been the subjects of intense investigations throughout evaluations of southern Nevada for possible nuclear-waste disposal (see Carr and Rogers, 1983; Crowe and others, 1983; Rogers and others, 1988; Crowe, 1991). Regional heat-flow studies are an important adjunct to more-focused investigations. Regional thermal regimes can help to put contemporary seismic and volcanic activity into a time perspective as regards tectonic processes, because on a regional scale, thermal processes have long time constants. Local thermal anomalies may also help pinpoint magma bodies that have no contemporary surface expression. Thermal and hydrologic regimes are closely related. In fact, both on local and regional scales, the deep thermal regime can be effectively masked or substantially altered by relatively slow movement of ground water (see Lachenbruch and Sass, 1977; Mase and others, 1982). This, in turn, makes thermal measurements sensitive indicators of fluid movement, and in some instances, allows quantitative estimates of flow velocities.

The Geothermal Studies Project, U.S. Geological Survey, has been actively engaged in thermal studies in and around the Nevada Test Site since the late 1950s (see Lachenbruch, 1958; Lachenbruch and others, 1987). The initial thrust of these studies was to provide high-quality data to define the regional heat-flow field. Hydrologic disturbances were noted in many wells, however, and data from the Nevada Test Site were instrumental in defining the Eureka Low (fig. 8.1), a large thermal anomaly, most probably of hydrologic origin, within the Basin and Range province (Sass and others, 1971). Our regional studies provided a context for a focused study of the Yucca Mountain area. Preliminary results (Sass and others, 1980; Sass and Lachenbruch, 1982) confirmed that the thermal regime was indeed distorted by the effects of water movement and provided data complementary to conventional hydrologic studies (Robison, 1984; Czarnecki and Waddell, 1984; Montazer and Wilson, 1984; Waddell and others 1984).

\section{THERMAL REGIME OF THE SOUTHWESTERN UNITED STATES}

The major thermal features of the region surrounding Yucca Mountain are outlined in figure 8.1. Modal heat flow for the region is in the range 60 to $100 \mathrm{~mW} \mathrm{~m}^{-2}$ (milliwatts 


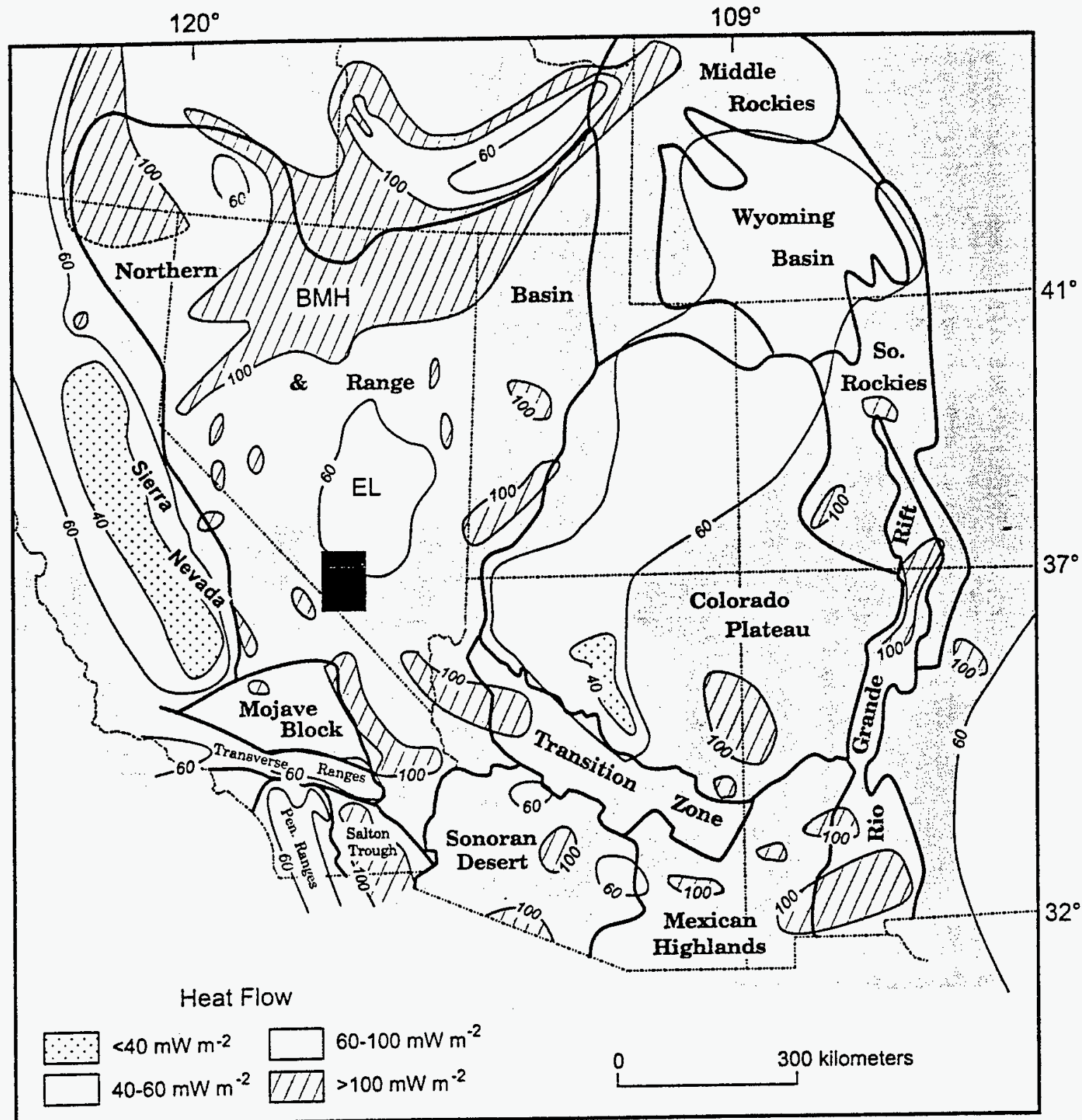

Figure 8.1. Distribution of heat flow in the western United States (modified from Sass and others, 1994). Abbreviations: BMH, Battle Mountain High; EL, Eureka Low. Black box at the south end of EL denotes location of figure 8.2. 
per square meter), but there are significant zones of both higher and lower heat flow. Most of these zones reflect the tectonic history of the area in question. For example, low heat flow in the Sierra Nevada is the result of a long-lived heat sink attributable to subduction during the late Tertiary. Areas of high heat flow like the Rio Grande Rift and the Salton Trough indicate Tertiary to present-day extension and accompanying magmatism (see Lachenbruch and Sass, 1977; Lachenbruch, 1958; Lachenbruch and others, 1987).

An exception to the general correlation between heat flow and tectonic history is the Eureka Low (EL, fig. 8.1). This feature, which represents a heat sink comparable in magnitude to the magmatic-hydrothermal heat source at Yellowstone (Lachenbruch and Sass, 1977), can be attributed to interbasin water flow in the Paleozoic carbonate rocks of the region. Independent thermal and regional hydrologic studies (Lachenbruch and Sass, 1977; Winograd and Thordarson, 1975) provide evidence that this large thermal feature is, indeed, hydrologic in origin, the result of lateral flow to depths of 3 to $4 \mathrm{~km}$ with a downward component of seepage velocity of only a few millimeters per year.

The Nevada Test Site and the Yucca Mountain area are located near the extreme southwestern limit of the Eureka Low (fig. 8.1). This was a fortunate happenstance in that it allowed deep tests of nuclear devices at the Nevada Test Site in a relatively lowtemperature environment. Early attempts at characterizing the heat flow in exploratory holes drilled on the Nevada Test Site were frustrating because of the evidence in temperature profiles for pervasive water flow. In some areas like Pahute Mesa (fig. 8.2), a large range of heat flow was measured within a relatively small area, and in one instance at different depths in the same deep hole (Sass and others, 1971; Lachenbruch and others, 1987; Sass and others, 1980). Yucca Mountain is also in an area of complex tectonic relationships including the dramatic contrast in elevation between the northern and southern Basin and Range (Borns and others, 1990; Saltus and Thompson, 1993).

\section{HYDROLOGIC SIGNIFICANCE OF HEAT FLOW NEAR YUCCA MOUNTAIN}

The regional thermal picture as it relates to Yucca Mountain may best be interpreted as a series of relatively shallow hydrologic perturbations, both regional and local, superimposed on a "normal" (65 to $95 \mathrm{~mW} \mathrm{~m}^{-2}$ ) Basin-and-Range heat-flow field (fig. 8.1). A detailed consideration of available heat-flow data from below the water table (fig. 8.2) in the vicinity of the Nevada Test Site confirms that Yucca Mountain is characterized by heat flows lower than regional and that it can be interpreted as being part of the Eureka Low. Over a distance of 30 to $40 \mathrm{~km}$ to the south, east, and west, heat flows are typical of the Basin and Range.

Near Yucca Mountain (Sass and others, 1988), heat flow in the unsaturated zone (UZ) varies, but it does so in a systematic fashion (fig. 8.3). The variation is partly geographic but is apparently also influenced by the thickness of the UZ and the temperature at the water table (fig. 8.4), which together determine the thermal gradient. The fact that heat 


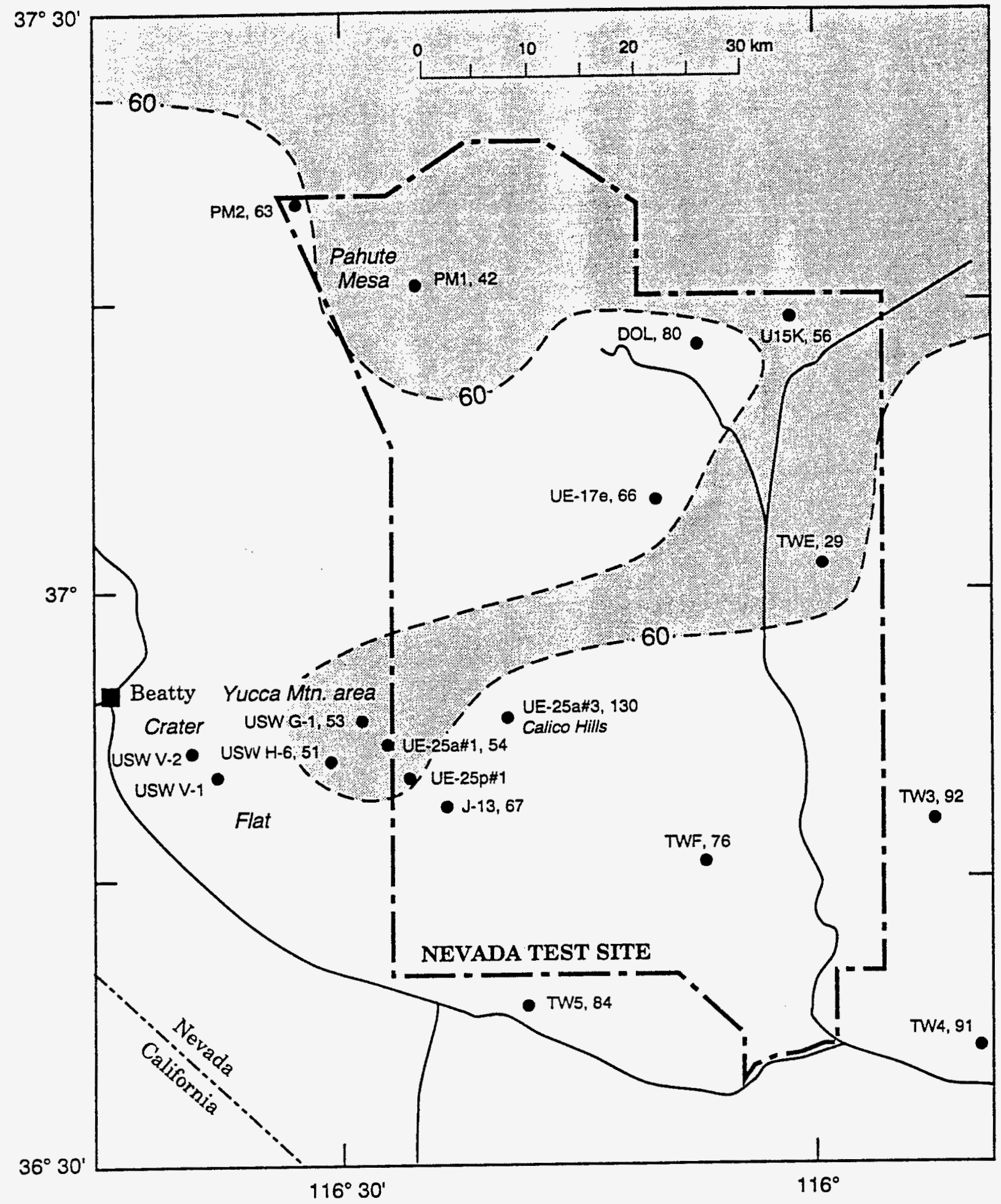

Figure 8.2. Configuration of $60 \mathrm{~mW} \mathrm{~m}^{-2}$ contour in the vicinity of the Nevada Test Site. Shaded area defines the southernmost part of the Eureka Low (see fig. 8.1). All heat flows shown were determined in the saturated zone (SZ). Where a heat flow could not be determined for the SZ (drill holes V-1, V-2, UE-25p\#1), no value is plotted. 


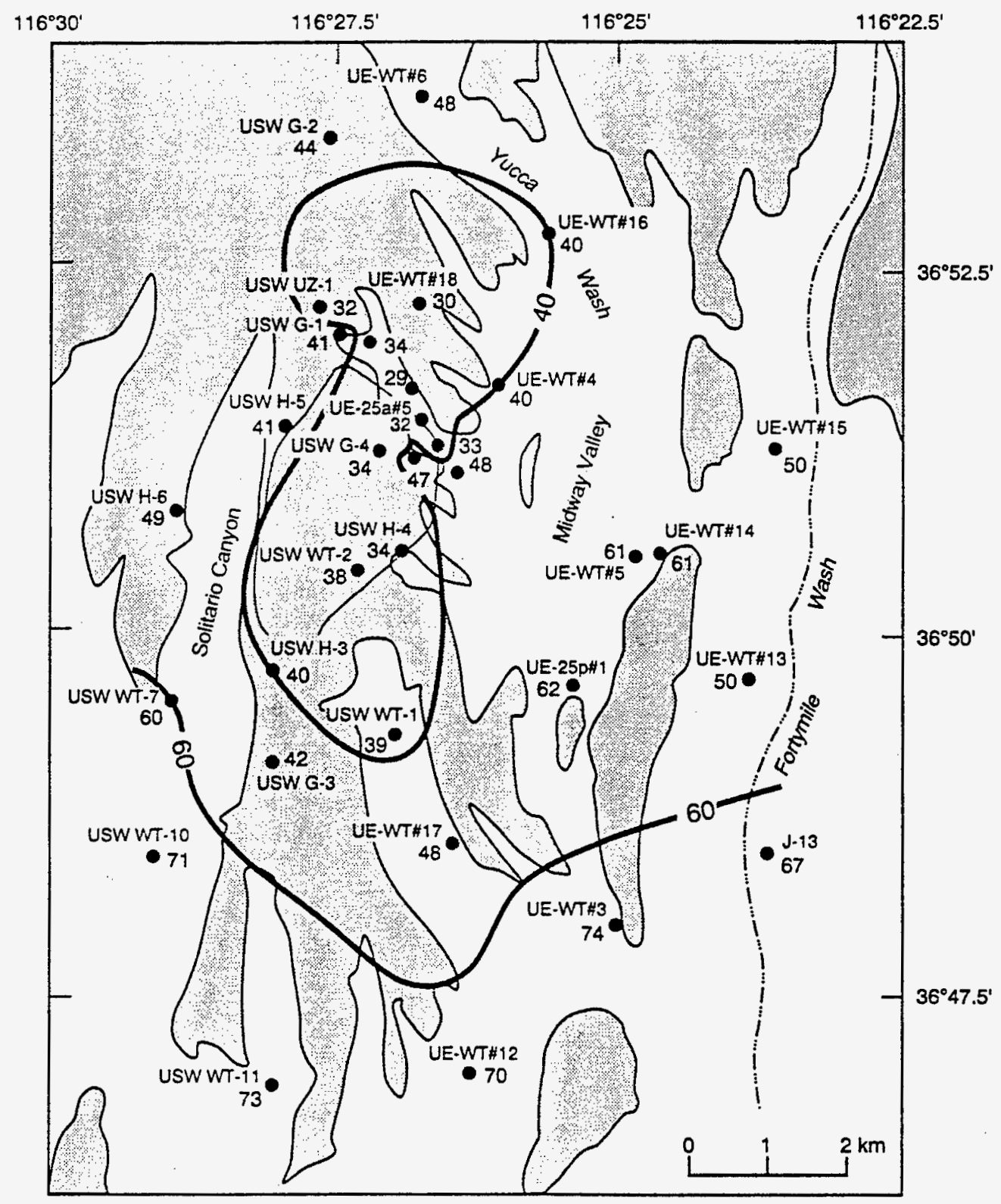

Figure 8.3. Conductive heat flow $\left(\mathrm{mW} \mathrm{m}^{-2}\right)$ from the unsaturated zone in the vicinity of Yucca Mountain. Light, solid line outlines plan of the potential repository. 
flow virtually doubles over a horizontal distance of 4 or 5 kilometers argues for a relatively shallow source for the variation.

In the UZ, the overall movement of moisture is downward, inviting application of a simple one-dimensional calculation (see Lachenbruch and Sass, 1977, equation 8) to estimate the magnitude of recharge that might account for the low heat flows (fig. 8.3). If we disregard local disturbances and assume a typical Basin and Range heat flow into the base of the UZ, the calculation results in an estimated recharge flux of 20 to $30 \mathrm{~mm} / \mathrm{yr}$, at least an order of magnitude greater than estimated by hydrologists (Montazer and Wilson, 1984). Furthermore, although estimates of heat flow from the subjacent saturated zone (SZ) are not consistent, particularly at depths less than $1 \mathrm{~km}$, they average less than half of regional and, within $95 \%$ confidence limits, are not significantly different from those obtained from the UZ (Sass and others, 1988). Consequently, the assumption of regionally normal heat flow into the base of the $U Z$ is violated, and the anomaly, if any, attributable to $\mathrm{UZ}$ processes is very small.

Measurements of hydraulic potential (head) in isolated zones of drill holes have been made routinely beneath the water table at Yucca Mountain (Robison, 1984). The computed vertical components of hydraulic gradient are very small in most holes, but they are upward wherever significant hydraulic gradients were observed in the thick Tertiary volcanic rocks. This indicates that downward percolation does not persist from the UZ into the $S Z$ and that some other condition or process causes the heat-flow deficiency in the $\mathrm{SZ}$ and most of the deficiency in the UZ.

Saturated-zone temperature logs (fig. 8.5a) are included from two drill holes (USW G1 and UE-25 p\#1) whose locations are shown on figure 8.3. The log for USW G-1, which penetrated only Tertiary volcanic rocks, shows minor hydrologic disturbance from the static water level at a depth of $572 \mathrm{~m}$ down to about $1030 \mathrm{~m}$. Beneath $1030 \mathrm{~m}$, the temperature profile is almost linear, indicating a principally conductive thermal regime. Thermal conductivities were determined for core samples from this hole, allowing a highconfidence heat-flow determination of $53 \mathrm{~mW} \mathrm{~m}^{-2}$ (Sass and others, 1988), only about $70 \%$ of the expected regional heat flow.

In contrast to the USW G-1 log, that from drillhole UE-25 p\#1 has no clearly conductive segments. Logs obtained before (during construction and hydraulic testing of the hole) and several years after the collection of the October $1983 \mathrm{log}$ show that the sharp excursions between depths of $475 \mathrm{~m}$ and $625 \mathrm{~m}$ were temporary and resulted from injection of warmer water from deeper in the drillhole into the formation during drilling. However, the water-table temperature, the nearly isothermal interval between $1200 \mathrm{~m}$ and $1400 \mathrm{~m}$, and the reversed profile beneath $1400 \mathrm{~m}$ have remained stable. The isothermal section begins near the base of the Tertiary section in basal sedimentary deposits and calcified tuffs and continues downward through a major fault zone into underlying Paleozoic carbonate rocks, which are present to the total depth of the hole (Carr and others, 1986). The top of the isothermal section is at the same depth at which, during drilling, the fluid level in the drillhole suddenly rose $20 \mathrm{~m}$, representing an increase of 


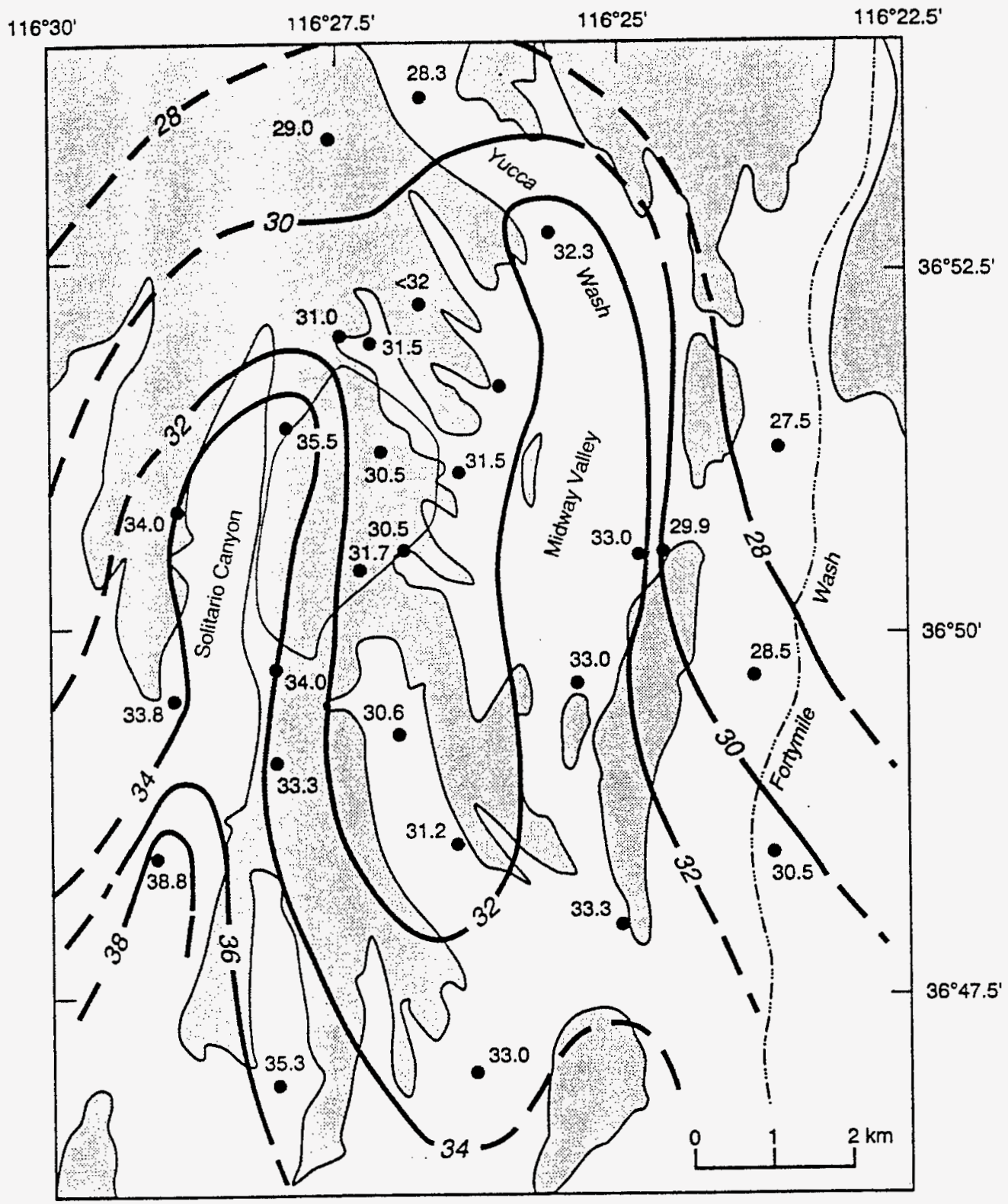

Figure 8.4. Temperature $\left({ }^{\circ} \mathrm{C}\right)$ at the water table in the vicinity of Yucca Mountain. Light, solid line outlines the plan of the potential repository. 

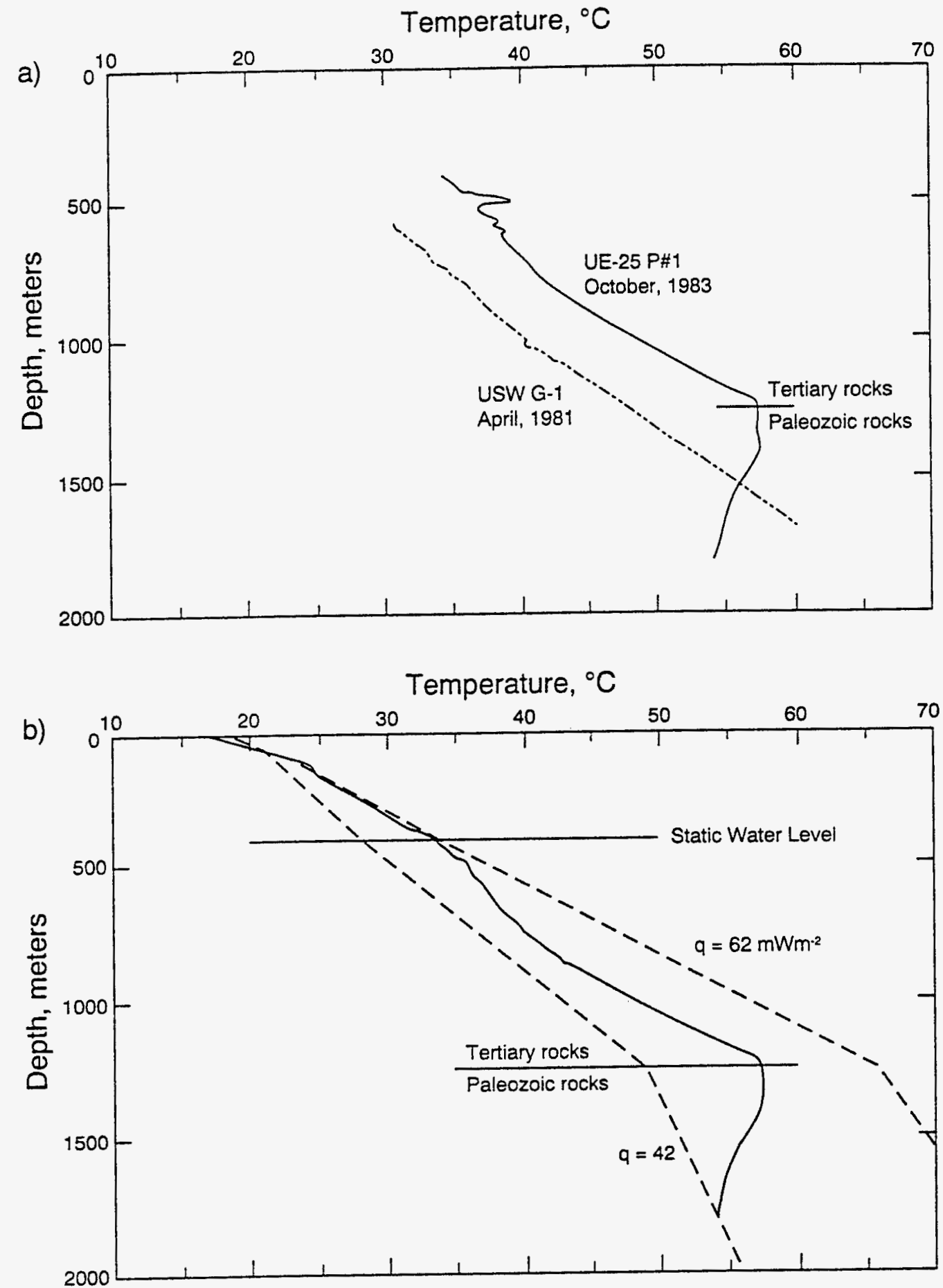

Figure 8.5. (a) Temperature profiles from the saturated zone, UE-25p\#1 and USW G-I. (b) Temperature profile of April 1990 from UE-25p\#1. Dashed lines are calculated temperature profiles for conductive heat fluxes of 42 and $62 \mathrm{~mW} \mathrm{~m}^{-2}$. 
hydraulic head that was later confirmed during hydraulic testing (Craig and Robison, 1984).

The Paleozoic rocks penetrated in the lower part of UE-25 p\#1 are part of a severalkilometer thickness of limestones and dolomites that is an important regional aquifer in the eastern and southern Great Basin (Winograd and Thordarson, 1975; Waddell and others, 1984). Interpretive compilations of geologic and geophysical information (for example, see Robinson, 1985) indicate that thick, northward-dipping sections of this aquifer underlie the volcanic rocks in the Yucca Mountain area. In turn, the carbonate aquifer is underlain by less-permeable Proterozoic (and lowermost Cambrian) clastic rocks, the top of which are considered generally to be the base of the actively circulating ground-water system. The carbonate aquifer becomes thinner erosionally southward (updip) as the Proterozoic clastic rocks rise structurally to crop out at the surface in the southern part of the region (fig.8.2). Heat flow determined by Sass and Lachenbruch (1982) for test well TW5 (fig. 8.2), which penetrates the Proterozoic clastic rocks, is normal for the Basin and Range province.

The low heat flow in the volcanic rocks at and near Yucca Mountain, both in the SZ and the UZ, apparently results from the capture of heat by water flow at depth in the Paleozoic carbonate aquifer. The depth to this aquifer is variable but is generally greater than $2 \mathrm{~km}$ near Yucca Mountain. The flow is primarily lateral, from which we infer that somewhere north of the anomaly, near the northern limit of the area (fig. 8.3,) relatively cool water is recharged to the carbonate aquifer. This is consistent with the interpretation of Fridrich and others (1994), who have proposed a hydrogeologic cause for the large southward hydraulic gradient defined by Robison (1984) at this approximate latitude, involving the downward diversion of water from relatively shallow depths into the carbonate aquifer.

Heat flows south of about $36048 \mathrm{~N}$ latitude (fig. 8.3), which approach normal regional values, indicate near equilibration of the water temperatures with normal rock temperatures at the depth of the carbonate aquifer in that area. Flanking the low heat-flow anomaly of central Yucca Mountain on the east and west are areas of somewhat greater heat flow and anomalously high temperatures at the water table (fig. 8.4). These areas correspond to the general positions of north-striking, high-angle $\left(60\right.$ to $\left.80^{\circ}\right)$ west-dipping faults. Recalling that vertical components of the hydraulic gradient (where they are observed) are upward, we infer that these faults partly disrupt the confinement of the carbonate aquifer and allow upward leakage of water that has been warmed while flowing southward in the aquifer.

The logs from drillhole UE-25 p\#1 (figs. 8.5a and 8.5b) provide the only continuous temperature data through the Tertiary section and a significant thickness of Paleozoic rocks in the immediate vicinity of Yucca Mountain. Although heat flow in the SZ is indeterminate for UE-25 p\#1, the location of the hole (fig. 8.2) suggests a heat flow close to that of the $60 \mathrm{~mW} \mathrm{~m}^{-2}$ border of the shaded area. This is consistent with the $62 \mathrm{~mW}$ $\mathrm{m}^{-2}$ value determined from the $\mathrm{UZ}$ segment of the temperature $\log$ (fig. $8.5 \mathrm{~b}$ ). It is also 
consistent with the rapid transition to typical Basin and Range conductive heat flow $>70$ $\mathrm{mW} \mathrm{m} \mathrm{m}^{-2}$ ) only a few kilometers to the south (fig. 8.3). Reconstruction of the expected temperature profile for a purely conductive heat flow of that value in the $S Z$, as depicted by the right-hand dashed line (fig. $8.5 \mathrm{~b}$ ), projects $\mathrm{SZ}$ temperatures significantly greater than those actually measured. Using the same vertical distribution of thermal conductivity and the observed temperatures at the surface and the bottom of the hole, the reconstructed conductive profile, as depicted by the left-hand dashed line (fig. 8.5b), corresponds with a heat flow of about $42 \mathrm{~mW} \mathrm{~m}^{-2}$ and projects much lower $\mathrm{UZ}$ and $\mathrm{SZ}$ temperatures than those measured. These alternatives bracket the probable range of actual heat flow. There is no unique solution, however, for either conductive or total heat flux, nor can a vertically consistent one- or even two-dimensional hydrologic model adequately describe the observed departure from one-dimensional conductive heat flow.

The UE-25 $\mathrm{p \# 1} \mathrm{logs} \mathrm{appear} \mathrm{to} \mathrm{be} \mathrm{qualitatively} \mathrm{consistent} \mathrm{with} \mathrm{the} \mathrm{interpretation} \mathrm{that}$ upward leakage of warm water occurs along high-angle faults, as proposed on the basis of water-table temperatures. Note that this temperature $\left(33^{\circ} \mathrm{C}\right)$ in UE-25 $\mathrm{p} \# 1$ helps to define an eastern north-trending high-temperature anomaly (fig. 8.4). The temporary positive temperature excursion about $100 \mathrm{~m}$ below the static water level on the October $1983 \mathrm{log}$ of UE-25 p\#1 (compare figs. 8.5a and 8.5b) probably reveals a permeable zone that corresponds approximately with a fault recognized by Carr and others (1986). The persistence of the broader positive deflection in the interval from about $400 \mathrm{~m}$ to $700 \mathrm{~m}$, though not of the shorter-wavelength excursions, and the stability of the water-table temperature in the later log (fig. 8.5b) indicate a long-lived geologic control for upward leakage, such as a fault zone. In this interpretation, the $62 \mathrm{~mW} \mathrm{~m}^{-2} \mathrm{UZ}$ heat flow owes in part to the anomalously high temperature at the base of the UZ resulting from the convective rise of heat along the fault zone.

The dominant feature of the UE-25 $\mathrm{p \# 1} \mathrm{log}$, the isothermal high-temperature segment between $1200 \mathrm{~m}$ and $1400 \mathrm{~m}$, probably does not reveal leakage upward through the volcanic rocks. Measured hydraulic heads in the volcanic section (Craig and Robison, 1984) increased only slightly with depth, providing no evidence of the much greater confined head that was encountered in the fault zone beneath the calcified basal tuff. Based on this single penetration of the fault zone, we speculate that the fault provides a steeply dipping, tabular, permeable zone that is hydraulically confined beneath the volcanic rocks but in which vertical mixing occurs throughout a significant thickness of the carbonate aquifer. Because of vertical mixing, the temperature within the upper part of this structural zone is greater than temperatures in the adjacent footwall rocks, accounting for the temperature reversal in the deeper segment of the drillhole.

The Paleozoic carbonate aquifer and the north-striking faults apparently provide important controls on both the SZ hydrology and the geothermal regime of Yucca Mountain. The low and variable heat flow does not identify or suggest any contemporary tectonic hazards; it does, however, underscore the complexity of the hydrologic regime. Careful studies and sophisticated modeling of the coupled thermal and hydrologic regimes will improve predictions of the locations and characteristics of flow paths in the SZ. Such 
coupled investigations will likely prove critical to confident definition of the cause for and implications of the large hydraulic gradient toward the site from the north.

Two areas within about $10 \mathrm{~km}$ east and west of the potential repository site may require additional consideration and possibly geothermal studies. The high heat flow (130 $\mathrm{mW} \mathrm{m}^{-2}$ ) at drillhole UE-25a\#3 in the Calico Hills (fig. 8.2) exceeds typical regional values by about $50 \%$ (Sass and others, 1980). The hole penetrates altered argillite and deeper weakly metamorphosed carbonate rocks of the Eleana Formation. The calculated heat flow is based on a linear temperature profile and measured thermal conductivities in the argillite, resulting in a high-confidence determination. Deeper in the hole, however, the apparent conductive heat flow is much smaller because of an almost isothermal temperature profile that indicates active downward flow, whether in both the rocks and the borehole or in only the borehole. Other use has precluded further studies in this hole, whereas an understanding of the anomaly would require a drillhole completion that precludes fluid movement in the open pathway provided by drilling.

In Crater Flat, between Yucca Mountain and Beatty to the west (fig. 8.2), basaltic volcanism and geophysical anomalies (see chaps. 3 and 7, this report) suggest the possibility of existing heat sources at depth. Temperature logs were obtained in two exploratory holes, but both logs are too distorted by in-hole flows to allow geothermal interpretations (fig. 8.6). We plan additional evaluation of existing information, but at present we consider that credible igneous targets may be too deep and too small in both volume and thermal energy to justify extensive, drilling-supported geothermal exploration. If further evaluation should justify additional geothermal studies for tectonic objectives, deep holes will be required to provide access beneath the hydrologically perturbed zone.

All heat-flow determinations to date in the SZ are suspect to some degree because of the ambiguity resulting from fluid movement in an open drillhole or an unfilled annulus surrounding the casing. We can detect very small water movements and estimate their vertical velocities from one-dimensional calculation. But, is this vertical movement occurring in the formation or is it simply movement in the drillhole in response to very small hydraulic gradients? Wherever feasible, the design of any deep geologic drill holes under consideration, including at least one that targets the Paleozoic carbonate rocks, should be modified to include casing or tubing and a grouted annulus to allow an unambiguous interpretation of the $\mathrm{SZ}$ temperature profile.

The preliminary thermal data that are available for the UZ indicate, though with a low level of confidence, that no significant hydrologic recharge is occurring there. These data also indicate, however, that a small (on the order of 5 to $10 \mathrm{~mW} \mathrm{~m}^{-2}$ ) negative anomaly may exist in the UZ (Sass and others, 1988). Processes that could contribute to this include downward percolation of water, vaporization of water, and advective discharge of heated and moisture-laden air to the surface. High-quality temperature logs offer a potentially useful data set for use in understanding these UZ processes. As in the SZ, however, there is a basic problem with the drillhole-completion procedures that limits our ability to obtain high-quality logs in the UZ. The problem is that there is nothing to inhibit 


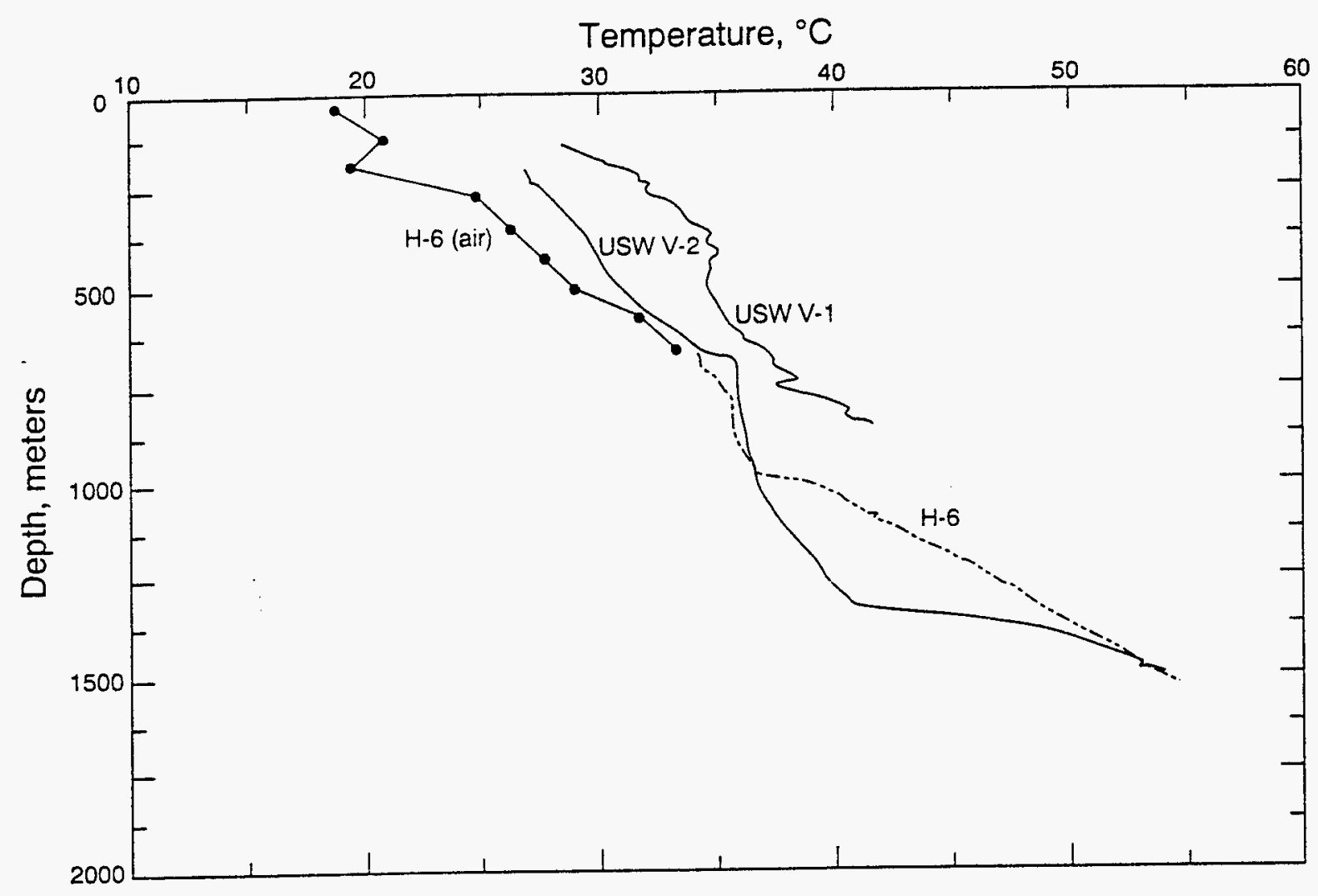

Figure 8.6. Temperature profiles in the vicinity of Crater Flat, west of Yucca Mountain (see fig. 8.2). 
the movement of fluid (in this case, air) under the influence of small head gradients or even barometric effects at the ground surface. Logging in air requires special equipment, is time-consuming, and provides individual temperature measurements only at widely spaced points. Continuous logs have been obtained in sealed-end, water-filled tubing in a few holes, but the annulus outside of the tubing has been open. Water-filled tubing is needed in more, areally well-distributed drill holes and, at a minimum, well heads should be sealed to prevent barometrically induced convective overturns of air in large-diameter casing or boreholes; preferably, the annulus would be filled, perhaps with sand, in a few holes.

An important supplement to UZ data obtained from surface-based holes will be acquired in the underground exploratory studies facility (ESF). We plan to make highresolution temperature measurements in near-horizontal holes drilled from the ESF across known high-angle faults and fracture zones in order to detect anomalies that indicate fluid movement along these zones. Conceptual models of water movement in the UZ (for example, see Montazer and Wilson, 1984) include the possibility that most flow occurs laterally under stratigraphic controls and then downward along faults.

Heat-flow investigations have, until recently, been grouped with studies of possible tectonism at Yucca Mountain, although distortion of the regional thermal regime in the southern Great Basin by ground-water flow was recognized more than two decades ago (Sass and others, 1971). More intensive studies of the Yucca Mountain area itself (Sass and others, 1988) have not resulted in any clear indications of tectonic hazards, but they have provided abundant evidence that characterization of the hydrologic system (in both the saturated zone and the unsaturated zone) will be greatly facilitated by detailed, highquality geothermal data.

\section{SUMMARY}

A considerable body of thermal data currently exists from the Yucca Mountain study area. Although the data are generally of poor quality (owing primarily to fluid movement in the annuli of boreholes), the transition between the Eureka heat-flow low and "normal" Basin-and-Range values of heat flow is well-documented. The preponderance of evidence is that there is little or no fluid movement within the tuffs in the unsaturated zone, but that water is moving in the upper kilometer of the saturated zone. There is a "bull's-eye" of low heat flow ( $\left.<40 \mathrm{~mW} \mathrm{~m}^{-2}\right)$ a few kilometers in principal dimensions, centered on the potential repository site. Little, if any, of the missing heat is being removed within the unsaturated Tertiary volcanic rocks that comprise the potential repository. The sketchy evidence available suggests that the heat sink lies within the Paleozoic carbonate rocks that underlie the volcanic rocks. Further deep drilling and reconfiguration of some existing boreholes will be required to answer the questions posed by the geothermal research to date. 


\section{REFERENCES CITED}

Borns, D. J., Sass, J. H., and Schweickert, R. A., 1990, Proposed study of the Basin and Range from Death Valley to Yucca Flat: EOS, v. 71, p. 1012-1013.

Carr, W. J., and Rogers, A. M., 1983, Tectonics, seismicity, and volcanism of the southern Great Basin, in U.S. Geological Survey Research in Radioactive Waste Disposal-Fiscal Year 1981: U.S. Geological Survey Water- Resources Investigations Report 83-4105.

Carr, M. D., Waddell, S. J., Vick, G. S., Stock, J. M., Monsen, S. A., Harris, A. G., Cork, B. S., and Byers, F. M., Jr., 1986, Geology of drill hole UE-25p\#1: A test hole to preTertiary rocks near Yucca Mountain, southern Nevada: U.S. Geological Survey OpenFile Report 86-175, $87 \mathrm{p}$.

Craig, R. W., and Robison, J. H., 1984, Geohydrology of rocks penetrated by test well UE-25 p\#1, Yucca Mountain area, Nye County, Nevada: U.S. Geological Survey WaterResources Investigations Report 84-4248, 57p.

Crowe, B. M., 1991, Basaltic volcanic episodes of the Yucca Mountain region: American Nuclear Society, Proceedings of the International Topical Meeting on High Level Radioactive Waste Management, v. 1, p. 65-73.

Crowe, B. M., Amos, R., Perry, F., Self, S., and Vaniman, D. T., 1983, Aspects of potential magmatic disruption of a high-level radioactive waste repository in southern Nevada: Journal of Geology, v. 91, p. 259-276.

Czarnecki, J. B., and Waddell, R. K., 1984, Finite-element simulation of ground-water flow in the vicinity of Yucca Mountain, Nevada-California: U.S. Geological Survey WaterResources Investigations Report 84-4349, 38 p.

Fridrich, C. J., Dudley, W. W., Jr., and Stuckless, J. S., 1994, Hydrogeologic analysis of the saturated-zone ground-water system under Yucca Mountain, Nevada: Journal of Hydrology, v. 154, p. 133-168.

Lachenbruch, A. H., 1958, Thermal measurements in the Oak Springs Formation, in Properties of the Oak Spring Formation in Area 12 at the Nevada Test Site, W. H. Diment and others, eds. U.S. Geological Survey Trace Elements Investigations Report TEI 672, chapter 11 .

Lachenbruch, A. H., Marshall, B. V., and Roth, E. F., 1987, Thermal measurements in the Oak Springs Formation at the Nevada Test Site, southern Nevada: U.S. Geological Survey Open-File Report 87-610, 19 p. 
Lachenbruch, A. H., and Sass, J. H., 1977, Heat flow in the United States and the thermal regime of the crust, in The Earth's Crust, J. G. Heacock, ed., American Geophysical Union, Geophysical Monograph 20, Washington, D.C., p. 626-675.

Mase, C. W., Sass, J. H., Lachenbruch, A. H., and Munroe, R. J., 1982, Preliminary heat-flow investigations of the California Cascades: U.S. Geological Survey Open-File Report 82$150,240 \mathrm{p}$.

Montazer, P., and Wilson, W. E., 1984, Conceptual hydrologic model of flow in the unsaturated zone, Yucca Mountain, Nevada: U.S. Geological Survey Water-Resources Investigations Report 84-4345, 55 p.

Robinson, G. D., 1985, Structure of pre-Cenozoic rocks in the vicinity of Yucca Mountain, Nye County, Nevada-A potential nuclear-waste disposal site: U.S. Geological Survey Bulletin 1647, 22 p.

Robison, J. H., 1984, Ground-water level data and preliminary potentiometric-surface maps of Yucca Mountain and vicinity, Nye County, Nevada: U.S. Geological Survey WaterResources Investigations Report 84-4197, 8 p.

Rogers, A. M., Harmsen, S. C., and Meremonte, M. E., 1988, Evaluation of the seismicity of the southern Great Basin and its relationship to the tectonic framework of the region: U.S. Geological Survey Open-File Report 87-408, 196 p.

Saltus, R. W., and Thompson, G. A., 1993, Why is it downhill from Tonopah to Las Vegas?: Geophysical constraints on isostatic support of the Great Basin [abs.]: EOS, v. 74, p. 548.

Sass, J. H., and Lachenbruch, A. H., 1982, Preliminary interpretation of thermal data from the Nevada Test Site: U.S. Geological Survey Open-File Report 82-973, 30 p.

Sass, J. H., Lachenbruch, A. H., Galanis, S. P., Jr., Morgan, P., Priest, S.S., Moses, T. H., Jr., and Munroe, R. J., 1994, Thermal regime of Arizona and the Mojave Desert of California and Nevada: Journal of Geophysical Research, in press.

Sass, J. H., Lachenbruch, A. H., and Mase, C. W., 1980, Analysis of thermal data from drill holes E25a-3 and UE25a-1, Calico Hills and Yucca Mountain, Nevada Test Site: U.S. Geological Survey Open-File Report 80-826, 25 p.

Sass, J. H., Lachenbruch, A. H., Munroe, R. J., Greene, G. W., and Moses, T. H., Jr., 1971, Heat flow in the western United States: Journal of Geophysical Research, v. 76, p. 6376-6413.

Sass, J. H., Lachenbruch, A. H., Dudley, W. W., Jr., Priest, S. S., and Munroe, R. J., 1988, Temperature, thermal conductivity, and heat flow near Yucca Mountain, Nevada: 
Some tectonic and hydrologic implications: U.S. Geological Survey Open-File Report $87-$ $649,118 \mathrm{p}$.

Waddell, R. K., Robison, J. H., and Blankennagel, R. K., 1984, Hydrology of Yucca Mountain and vicinity, Nevada-California-Investigative results through mid-1983: U.S. Geological Survey Water-Resources Investigations Report 84-4267, 72 p.

Winograd, I. J., and Thordarson, W., 1975, Hydrogeologic and hydrochemical framework, south-central Great Basin, Nevada-California, with special reference to the Nevada Test Site: U.S. Geological Survey Professional Paper 712C, 126 p. 


\title{
MAJOR RESULTS OF GEOPHYSICAL INVESTIGATIONS AT YUCCA MOUNTAIN AND VICINITY, SOUTHERN NEVADA
}

\section{CHAPTER 9: STRESS MEASUREMENTS}

\author{
by John H. Healy
}

\section{INTRODUCTION}

The selection of sites for the permanent disposal of nuclear waste is one of the most challenging problems facing earth scientists today. The scientific studies directed toward this goal differ in important ways from a typical scientific investigation. The differences arise from the high level of confidence required in the certification of a proposed site. A site selected for the permanent disposal of nuclear waste will have dangerous contamination for more than 100,000 years. It has been proposed that the site should prevent significant leakage of waste products for at least 10,000 years at a level of confidence exceeding $1 / 1,000,000$ per year. These very severe restrictions are difficult to interpret in geological terms, as one million years is a more typical time scale for the consideration of geologic processes. The goal of successful site identification is to identify and evaluate possible mechanisms that might contribute to failure of a repository.

The state of stress by itself does not pose a threat to a potential repository at Yucca Mountain, Nevada. It is important because it relates to other mechanisms that may threaten the repository. The likelihood of earthquakes, volcanism, and faulting are influenced by the state of stress. Yucca Mountain took its present shape about ten million years ago following a period of extensive volcanism and the development of basin-and-range structures in the region, and since that time Yucca Mountain has been relatively stable. If we could return to this region one million years in the future we would probably find Yucca Mountain essentially unchanged. The greatest concern associated with the state of stress is the possibility of some interaction between the stress field and the hydrologic regime that might cause fluctuations in the water table.

Measurements in borehole USW G-1, which we emphasize in this report, were made in December 1981 about $500 \mathrm{~m}$ northeast of the potential repository boundary (see fig. 1.4). The observed state of stress was recognized as a matter of concern, and additional measurements were made in three other holes on Yucca Mountain (USW G-2, USW G-3 and UE-25 p\#1). These additional measurements, in general, confirmed the observations made in USW G-1 and support the conclusion that the rocks at Yucca Mountain are close to failure. All of this work has been reported in the literature, in open-file reports, including Healy and others (1984), Stock and others (1984), and Stock and others (1986).

The implications of these stress measurements at Yucca Mountain have been a matter of controversy. J.S. Szymanski, in an extensive series of DOE internal reports (National Research Council, 1992), argued that a sudden change in stress could force water up into a repository with catastrophic results. Szymanski argued on the basis of his analysis that Yucca Mountain was not a suitable site for the disposal of nuclear waste. This work was widely reviewed and criticized, culminating in an extensive review by a panel of the National Academy of Sciences (National Research Council, 1992). The National Academy of Sciences in its review of this question 
concluded that there is no evidence to support an assertion of water-table rise in response to stress at Yucca Mountain (National Research Council, 1992).

Temporary earthquake-induced water-level fluctuations were observed in instrumented boreholes at Yucca Mountain (O'Brien, 1993) following the magnitude 5.6 earthquake in June 1992 at Little Skull Mountain, $23 \mathrm{~km}$ southeast of the potential repository. Maximum estimated short-term water-level fluctuation from the Little Skull Mountain earthquake was $40 \mathrm{~cm}$. Most responses caused by the Little Skull Mountain earthquake (and one-day-earlier larger earthquakes at Landers and Big Bear Lake, California) were small and of short duration. Water level and fluid pressure in continuously monitored wells rose sharply by modest amounts and then receded, typically in hours, to pre-earthquake levels. The Little Skull Mountain earthquake caused responses that were probably due in part to changes in the regional strain field (O'Brien, 1993) in addition to effects from the passage of seismic waves, but disruptions were minor and temporary.

The fluid pressure required to fracture rock in a borehole reflects the state of stress in the fractured rock. When hydraulic fracturing measurements are made under carefully controlled conditions in a suitable section of rocks, plots of pressure and volume versus time can be used to estimate the magnitudes of the two principal components of horizontal stress. The density of the rocks above the point of measurement determines the vertical stress. The orientation of the vertical fracture produced in the test indicates the orientation of the horizontal stresses. Under ideal conditions this is a simple measurement. In practice many things can go wrong, and many attempts to measure stress fail to produce reliable data.

Each drill hole presents its own unique conditions, and standard techniques and equipment may have to be modified to obtain reliable data. One unusual condition encountered in drill holes on Yucca Mountain is the depth of the water table, more than 500 meters below the surface. This condition required some modification of our standard procedures and made the estimate of the greatest horizontal stress more difficult. Ideally, stress measurements on Yucca Mountain should be made with a system designed specifically for these measurements.

The stress on Yucca Mountain favors normal faulting where the least stress is horizontal and the greatest stress is vertical. Under these conditions, the uncertainty in estimating the greatest horizontal stress is relatively unimportant, and we can estimate the maximum shear stress with a high degree of confidence. The deep water table is an advantage in the interpretation of the data because we can examine the effect of this unusual fluid pressure on the stress field.

Borehole logs are used to identify an unfractured section of rocks. A part of this unfractured section is then isolated by inflatable rubber packers, and fluid pressure is applied to the isolated section by pumping fluid through tubing from the surface. The pressure in the isolated section and the rate of fluid flow are continuously recorded during the test. At first the system responds elastically with a linear increase of pressure versus volume of fluid pumped, until a breakdown pressure is reached. Immediately after breakdown, pumping is stopped, and the fluid is allowed to flow back to the surface until the pressure reaches a value equal to the weight of the column of water in the tubing. The sequence is repeated. The breakdown pressure on the second cycle is smaller than on the first cycle, and the difference is a measure of the tensile strength of the 
unfractured rocks. On the second cycle the pumping is stopped but the system is kept closed to observe the drop-off of fluid pressure as the fluid leaks into the newly formed fracture. There is typically a marked inflection in the pressure-time plot as the fracture closes.

The greatest horizontal stress can be estimated from the relationship of breakdown pressure, tensile strength, and pore pressure in the rocks. This relation assumes that the hole is round with no preeexisting fractures in the rocks. It is further assumed that the rocks are elastic and isotropic and that there is no penetration of well-bore fluid into the rocks before breakdown. Part of the art in this method is the precise control of flow rates to limit the size of the initial fracture. A small fracture can be opened and closed about five times to provide a number of estimates of the fractureclosing pressure which we interpret as the least principle stress. The fracture is altered as the tests proceed and the character of the pressure-time history changes, so that after about five cycles it no longer provides a clear indication of the fracture opening and closing pressures. Additional estimates of the least horizontal stress can be obtained by pumping fluid into the fracture at a number of constant flow rates and observing the pressure required to maintain each flow rate. A plot of pressure versus flow rate typically shows a sharp change in slope when the pressure crosses the least horizontal stress.

In each test section a number of estimates of the least horizontal stress are obtained as compared to a single estimate of the greatest horizontal stress. The greatest horizontal stress is not related directly to the observed pressures but calculated from a relationship based on questionable assumptions about the character of the rocks and the condition of the drill hole. Most of the uncertainty in the determination of the stress field is related to the greatest horizontal stress, and the goal of improving these estimates is the subject of current research. Determination of the least horizontal stress, which is important in the following discussion, is relatively straightforward using generally accepted methods. The vertical stress at Yucca Mountain is well known from extensive sets of borehole density logs and core samples (Healy and others, 1984; Stock and others, 1984; and Stock and others, 1986).

\section{DATA FROM BOREHOLE USW G-1}

Stress measurements were made at six depths in USW-GI (Healy and others, 1984). The data are tabulated in table 9.1 and plotted in figure 9.1. The relevant stress parameters for many stress-dependent rock properties are the effective stress, the total stress minus the fluid pressure, Po. The dimensionless stress parameter, $R=(t / n) \max$, the maximum ratio of shear to effective normal stress, and $\theta$, the dip angle of the plane on which this maximum occurs, are explicit functions of the stress parameter $\mathrm{k}$. The stress parameter $\mathrm{R}$ may be expressed in the function $\mathrm{R}=$ $(1-\mathrm{k}) /\left(2(\mathrm{k})^{0.5}\right)$, and the dip angle as $\theta=\pi / 4-(1 / 2) \arctan (\mathrm{R})$. The stress parameter, $\mathrm{k}=($ Sh$\mathrm{Po}) /(\mathrm{Sv}-\mathrm{Po})$, where Sv is the vertical stress, is constant with depth in these measurements within the expected accuracy of the measurements. The values of the measured stresses and corresponding $k$, $\mathrm{R}$, and $\theta$ parameters in drill hole USW G-1 are shown (table 9.1). The data indicate a linear gradient for least horizontal stress, Sh. The values of Sh increase linearly with depth in the function: $\quad \operatorname{Sh}(\mathrm{MPa})=5.13+0.15 *$ depth (meters). 


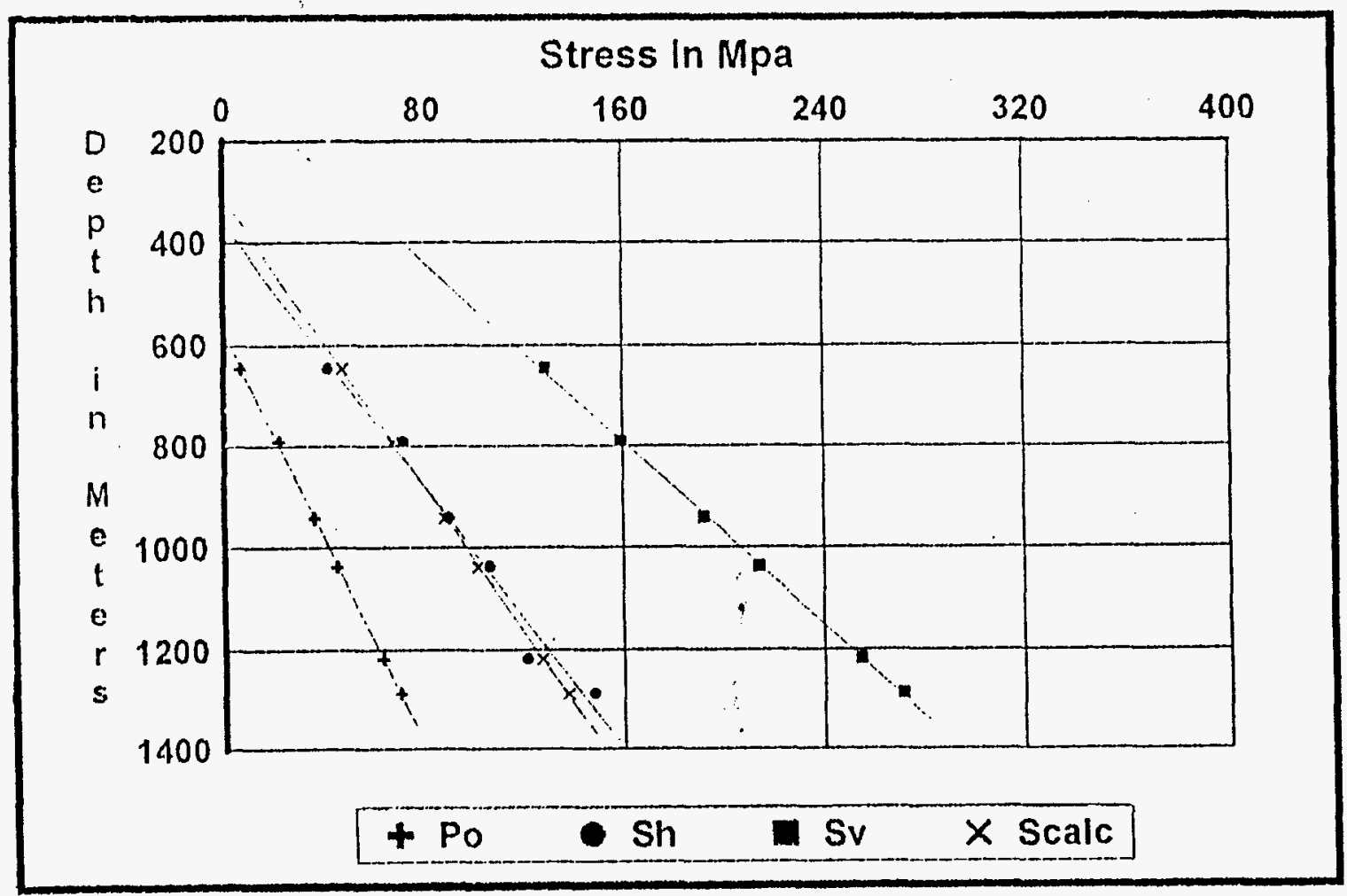

Figure 9.1. Stress data from borehole USW G-1. Symbols, $+-P_{0}$, the measured fluid pressure in the well bore, assumed to be the fluid pressure in the rocks near the well bore (note that pressure equals zero at $580 \mathrm{~m}$, the depth of the water table in this well); $-\mathrm{S}_{\mathrm{v}}$, vertical stress determined from the integrated density logs in this well; $-S_{h}$, least horizontal stress determined from the fracture-closing pressure in the hydrofracture tests; $X-S_{\text {calc }}$, calculated least horizontal stress from the assumption that $S_{h}=1 / 3\left(S_{v}-P_{0}\right)+P_{0}$. 
Table 9.1.-Stress measurements and calculated parameters based on measurements at six depths in USW G-1 at Yucca Mountain, Nevada (modified after Healy and others, 1984).

\begin{tabular}{|c|c|c|c|c|c|c|c|c|}
\hline Depth, m & 646 & 792 & 945 & 1038 & 1218 & 1288 & Mean & Std \\
\hline$\overline{\mathrm{P}_{\mathrm{o}}(\mathrm{MPa})}$ & 0.7 & 2.2 & 3.6 & 4.5 & 6.3 & 7.0 & & \\
\hline$S_{V}$ & 12.9 & 15.9 & 19.2 & 21.4 & 25.5 & 27.2 & & \\
\hline$S_{h}$ & 4.2 & 7.9 & 9.0 & 10.6 & 12.1 & 14.8 & & \\
\hline $\mathrm{k}$ & 0.29 & 0.36 & 0.35 & 0.36 & 0.30 & 0.39 & 0.34 & 0.04 \\
\hline $\mathbf{R}$ & 0.66 & 0.53 & 0.55 & 0.53 & 0.64 & 0.49 & 0.57 & 0.06 \\
\hline$\theta$ & 61.7 & 59.0 & 59.4 & 49.0 & 61.3 & 58.0 & 59.7 & 1.3 \\
\hline
\end{tabular}

Abbreviations: $P_{0}=$ effective stress (total stress - fluid pressure); $S_{V}=$ vertical stress; $S_{h}=$ least horizontal stress; $k=$ stress parameter; $R=$ stress parameter $(1-k) /\left(2(k)^{0.5}\right)$; and $\theta=$ slip angle of plane of maximum $R$. See text for additional details.

\section{CONCLUSIONS AND DISCUSSION}

The measurements in USW G-1 support the tentative conclusion that the data and the model suggest that the rocks penetrated by drill hole USW G-1 are near a state of incipient failure along faults striking $\mathrm{N} 65^{\circ} \mathrm{W}$ and dipping at approximately 60 degrees. The systematic linear increase of the magnitude of horizontal stress (Sh) with depth suggests that this stress may reflect some failure mechanism. Measurements in USW G-2 (Stock and others, 1984) and USW G-3 (Stock and others, 1986), are consistent with this conclusion. We know of no data that convincingly refute this conclusion. This conclusion is based on an analysis of the observations of the least horizontal stress, the vertical stress and the fluid pressure using very elementary physics and very few explicit or implicit assumptions. The assumption that the vertical stress is a principal stress and equal to the weight of the overburden requires some degree of lateral homogeneity of the stress field which in turn implies some degree of lateral homogeneity of the rocks and of their deformation history. This is a very reasonable assumption for the measurements in USW G-1, and it is unlikely that minor variations in the vicinity of this hole would significantly violate this assumption. The analysis assumes that the rocks can support the calculated stresses and that there is sufficient porosity and permeability so that uniform fluid pressure can exist in the medium. These assumptions are supported by the observations and by many laboratory measurements.

The conclusion depends on the observed stress gradient which in turn depends on the accuracy of the observed least horizontal stresses. The discovery of unrecognized sources of error might change this conclusion. Current use of new equipment to redigitize the data and make presentations will facilitate a new analysis of the possible errors in these measurements. 
Additional stress measurements might alter this conclusion. Measurements at greater depths would be particularly interesting. Without a much more complete description of the stress field from in situ stress measurements, it is unlikely that any combination of laboratory measurements and analysis will alter the conclusion that the rocks at USW G-1 are subject to stresses that may be close to their long-term strength. Stresses observed in the earth reflect the response of rocks to deformation that has occurred over a long period of time. Higher stresses may be required to produce catastrophic deformation or slow deformations that would seriously compromise the repository in its active lifetime of 50 to 100 years. With our current level of knowledge, it is difficult to predict the effects of the observed stresses over a period of 10,000 years.

Other data exist that may bear on this conclusion. Triggering of earthquakes by nuclear tests to the north of Yucca Mountain is convincing evidence that some rocks in the region are close to failure. The absence of earthquakes on Yucca Mountain in recent years provides no evidence for stability because many active faults are quiet for long periods between earthquakes. The young volcanism in Crater Flat indicates the presence of deep magma sources near the site which suggest potential for some tectonic movement in recent geologic time and in the future.

The possibility that the rocks on Yucca Mountain are subject to stresses which are close to their limiting strength is not necessarily an unfavorable factor. The properties of Yucca Mountain which make it a favorable site for waste disposal result from extensive tectonic activity in the past, and it is unlikely that these favorable properties could be found at a site that is completely inactive. There is evidence that many other locations are subject to stresses that are close to the strength of the rocks. At Denver, Colorado, the Army triggered earthquakes by injecting waste fluids into a 4$\mathrm{km}$-deep disposal well (Healy and others, 1968). Earthquakes were triggered by the injection of fluids in an oil field at Rangely, Colorado, and a special experiment demonstrated that the earthquakes could be turned on and off by changing the fluid pressure (Raleigh and others, 1976). Earthquakes were triggered near Yucca Mountain by nuclear testing on Pahute Mesa (Hamilton and Healy, 1969). In these three cases there was no evidence of significant tectonic activity for at least several million years. Many other examples could be cited.

In many cases the emergence of unexpected instabilities has had significant economic cost. At Denver, the Army chose to abandon the disposal well and use other methods for waste disposal which also proved to be unsatisfactory. It is probable that a careful study of this site could have led to the design of a safe disposal well. In the opinion of the author, stresses in Yucca Mountain may cause similar problems. At any time during the life of the repository the occurrence of a moderate earthquake or some other unexpected tectonic event might lead to restrictions on the use of the site.

Our limited knowledge of the rheology of crustal rocks, particularly the properties of large fault zones at depth, and the lack of data on the distribution of stresses in the crust constrains our ability to predict tectonic activity. It is important to pursue programs that will reduce this uncertainty in our basic knowledge of the Earth. A well-managed and adequately funded national program of sampling and measurements in deep boreholes is important for our understanding of Yucca Mountain and many other sites where uncertainties of this nature may have serious economic consequences. 


\section{Acknowledgments}

Many people provided helpful criticism and comments on this paper. Art McGarr, Jim Byerlee, Carolyn Morrow, and Joan Stock provided extensive comments on an early version of the paper. Mary Lou Zoback and Steve Hickman reviewed the final version of the paper. Jim Savage derived the relations between the stress parameters which we used to develop the paper. We wish to thank these people and others whom we have not named for their help and encouragement in this work. 


\section{REFERENCES CITED}

Hamilton, R. M., and Healy, J. H., 1969, Aftershocks of the Benham Nuclear Explosion: Bulletin of the Seismological Society of America, v. 59, no. 6, p. $2271-2281$.

Healy, J. H., Hickman, S. H., Zoback, M. D., and Ellis, W. L., 1984, Report on televiewer log and stress measurements in core hole USW G-1, Nevada Test Site, December 13-22, 1981: U.S. Geological Survey Open-File Report 84-15, 51 p.

Healy, J. H., Rubey, D. T., Griggs, D. T., and Raleigh, 1968, The Denver earthquakes: Science, v. 161, p. $1301-1310$.

National Research Council, 1992, Ground water at Yucca Mountain: how high can it rise?:

Washington, D.C., National Academy Press, 231 p.

O'Brien, G.M., 1993, Earthquake-induced water-level fluctuations at Yucca Mountain, Nevada, June 1992: U.S. Geological Survey Open-File Report 93-73, 12 p.

Raleigh, C. B., Healy, J. H., and Bredehoeft, J. D., 1976, An experiment in earthquake control at Rangely, Colorado, Science, v. 191, p.1230-1237.

Stock, J. M., Healy, J. H., Svitek, J., and Mastin, L., 1986, Report on televiewer log and stress measurements in holes USW G-3 and UE-25p\#1, Yucca Mountain, Nevada Test Site: U.S. Geological Survey Open-File Report 86-369, 91 p.

Stock, J.M., Healy, J.H., and Hickman, S.H., 1984, Report on televiewer log and stress measurements in core bole USW G-2, Nevada Test Site: U.S. Geological Survey Open-File Report 84-172, 48 p. 


\title{
MAJOR RESULTS OF GEOPHYSICAL INVESTIGATIONS AT YUCCA MOUNTAIN AND VICINITY, SOUTHERN NEVADA
}

\section{CHAPTER 10: INTEGRATION OF METHODS AND CONCLUSIONS}

\author{
By H.W. Oliver and E.L. Hardin
}

The Yucca Mountain site is structurally complex and has other aspects that complicate geophysical exploration, such as high resistivity and low seismic velocity and density near the surface. Because of these conditions and the scope of past activity, several important questions of hydrologic and tectonic significance have not been sufficiently addressed to date by geophysicists. However, major results have been obtained and will be used in sitecharacterization activities. It is very likely that some existing data presented here will be used toward licensing of this potential site for storage of high-level radioactive waste.

This volume presents the results of selected geophysical investigations at or near Yucca Mountain. The reader should note variation in time frame of these investigations; compilations presented here were prepared over several years between the late 1980s and the early 1990s. The studies were conducted over a broader period according to the dictates of funding and availability and applicability of specific methods. Updates have been added where possible, but this volume represents results through 1990 and can not everywhere represent the latest work. The reader should note the position of this report, as noted above, in a sequence of efforts describing geophysical investigations at Yucca Mountain. The Site Characterization Plan (U.S. Department of Energy, 1988) and the Geophysical White Paper, Phase I (Oliver and others, 1990), are important companions and precursors to the present volume.

Results of geophysical investigation have provided major input to characterization efforts and include crustal exploration using the combination of gravity and seismic refraction, which has provided information on the thickness of tuffs in Crater Flat and the depth to the Paleozoic-Tertiary contact associated with major features of the site (see chaps. 2 and 5). Buried volcanic rocks have been indicated by magnetic surveys in the vicinity of the site and in the Amargosa Desert (chap. 3) and confirmed by drilling. Successful application of intermediate-depth seismic refraction has been demonstrated at the site, and the use of shallow seismic refraction methods to characterize faults has also been demonstrated successfully (chap. 5). Geoelectric methods have been used in the Yucca Mountain region and site area for vertical sounding and profiling applications, producing preliminary results to be further evaluated during site characterization (chap. 4.). Five magnetotelluric surveys have also been made which provide electrical cross-sections across the southern part of Yucca Mountain and across the Walker Lane southwest of Yucca Mountain. These surveys have been interpreted to show that four main resistivity layers in the Yucca Mountain region have resistivity values of 10 to 30,30 to 100 , and 300 to $1000 \mathrm{ohm}-\mathrm{m}$ at increasing depths of 0 to $15 \mathrm{~km}$, with a deeper mid-crustal low-resistivity zone of 3 to $30 \mathrm{ohm}$-meters. 
Additional methods have also been productive. Teleseismic tomography (chap. 7) reveals a low-velocity feature in the lower crust under Crater Flat and supports gravity and seismic refraction evidence that the Crater Flat "depression" extends eastward under Yucca Mountain very near to the potential repository area. Heat flow (chap. 8) under Yucca Mountain is abnormally low, about 1.1 heat-flow unit (HFU). The low heat flow is thought to be caused by an interbasin water flow with a downward component of seepage velocity of a few $\mathrm{mm} / \mathrm{yr}$. Thus, heat-flow studies are more relevant to hydrologic characterization than to identification of tectonic hazards. Stress measurements (chap. 9) show that the present state of stress at Yucca Mountain is consistent with recurrent movement on normal faults dipping about $60^{\circ}$ and striking about N25 $\mathrm{E}$. The measurements made in drill hole USW G-1 are regarded as the best available because of its moderate hole diameter of about $12 \mathrm{~cm}$, and measurements indicate that the rocks at depths of 600 to $1300 \mathrm{~m}$ are subject to stresses that may be close to their long-term strength. The water table may be coupled to the tectonic stress field.

Some problems were encountered with high-resolution seismic reflection (chap. 6) along the eastern flank of Yucca Mountain (McGovern and others, 1983), but more recent reflection tests by Brocher and others (1993) and shallow high-resolution lines by E.L. Majer (of Lawrence Berkeley National Laboratory), summarized by Oliver and others (1994), were very encouraging, leading to successful acquisition in 1994 of $37 \mathrm{~km}$ of intermediate-depth seismic reflection data across Yucca Mountain (Brocher and others, 1995). The highresolution, shallow profiles were acquired with a $13-\mathrm{m}$ seismometer spacing and a $30,000 \mathrm{ft}-\mathrm{lb}$ impact source operated at 3-m intervals, producing 24 -fold data. Preliminary results across the Ghost Dance fault suggest that the fault is part of a complex zone of faulting and fracturing that may be several hundred meters wide and extend to a depth of about $1 \mathrm{~km}$. These conclusions are supported by detailed gravity and magnetic data (Ponce and Langenheim, 1995), and they are consistent with surface mapping. The intermediate-depth regional seismic reflection profiles (Brocher and others, 1995; more extensive reports in progress) contain images of the top of the pre-Tertiary section and provide evidence against shallow detachment faulting at Yucca Mountain.

Other geophysical methods have become generally available since the previous work was performed, including vertical seismic profiling (VSP), new methods for surface seismic data acquisition and processing, and thermal infrared imaging. Because the success of these new approaches will depend on site-specific factors that have not yet been fully assessed, the Site Characterization Plan (U.S. Department of Energy, 1988) contains plans to review the available capabilities, perform feasibility testing, and apply them to site characterization as appropriate.

Contrasts in seismic velocity, density, electrical resistivity, and magnetic properties are needed to observe geophysical structure. These changes are typically subtle at Yucca Mountain, with a few exceptions. The Paleozoic-Tertiary contact is marked by a contrast in density and possibly in seismic properties. Much of the structure of interest lies within the Tertiary section, where the magnetic and seismic properties of welded tuff contrast with nonwelded tuff. However, contrast can be muted even at major interfaces such as the 
alluvium-tuff, welded-nonwelded tuff, and Paleozoic-Tertiary contacts, where there may have been weathering or alteration such that the variation in geophysical properties is gradational.

Because of site-specific factors and problems such as those encountered with seismic reflection at the site, it is presently expected that each geophysical method will produce only a partial model. An integrated approach is therefore planned for major objectives including investigation of the large hydraulic gradient north of the potential repository area (Ervin and others, 1993), characterization of the repository block, detection and delineation of faults, and structural profiling across the site area. Many of these efforts will feed to overall goals of describing tectonic setting and evaluating earthquake hazards. Plans in the Site Characterization Plan call for gravity, magnetic, and seismic-reflection surveys with increased coverage and resolution relative to existing data, following this strategy. At the same time, feasibility testing and technical review are planned to assess methods for detailed shallow- and intermediate-depth investigations. Reviews of seismic reflection and geoelectric methods will consider past results and produce recommendations for using these methods to augment gravity, magnetic, and seismic refraction surveys. Additional feasibility testing may be recommended by these reviews and is already planned to evaluate the Mini-Sosie seismic reflection method, vertical seismic profiling, radar, remote sensing applications, and radiometric methods (Oliver and others, 1990, Section 3.3).

Within the site-characterization framework, many different activities may depend on geophysical data. Integration among activities is needed to respect the interfaces between these activities (Oliver and others, 1990), and to ensure that the characterization program provides timely information appropriate to support a repository license application. 


\section{REFERENCES CITED}

Brocher, T.M., Carr, M.D., Fox, K.F., and Hart, P.E., 1993, Seismic reflection profiling across Tertiary extensional structures in the eastern Amargosa Desert, Basin and Range, USA: Geological Society of America, v. 105, p. 30-46, 1 plate.

Brocher, T.M., Hart, P.E., and Hunter, W.C., 1995, Hybrid source seismic reflection profiling across Yucca Mountain, Nevada: International Union of Geodesy and Geophysics, XXI General Assembly, Boulder, CO, Abstracts, p. A391.

Ervin, E.M., Luckey, R.R., and Burkhardt, D.J., 1993, Summary of revised potentiometricsurface map for Yucca Mountain and vicinity, Nevada: American Nuclear Society, High Level Radioactive Waste Management, Proceedings of the Fourth Annual International Conference, v. 2, p. 1554-1558.

McGovern, T.F., Pankratz, L.W., and Ackermann, H.D., 1983, An evaluation of seismic reflection studies in the Yucca Mountain area, Nevada Test Site: U.S. Geological Survey Open-File Report 83-912, 57 p.

Oliver, H.W., Hardin, E.L., and Nelson, P.H., eds., 1990, Status of data, major results, and plans for geophysical activities, Yucca Mountain Project: U.S. Department of Energy Report YMP/90-38, $191 \mathrm{p}$.

Oliver, H.W., Majer, E.L., and Spengler, R.W., 1994, Geophysical investigations of the Ghost Dance fault, Yucca Mountain, Nevada [abs.]: Geological Society of America, Cordilleran Section Meetings, v. 24, no. 2, p. 78.

Ponce, D.A., and Langenheim, V.E., 1995, Gravity and magnetic investigations of the Ghost Dance and Solitario Canyon faults, Yucca Mountain, Nevada: U.S. Geological Survey Open-File Report 95-521, $26 \mathrm{p}$.

U.S. Department of Energy, 1988, Site characterization Plan: U.S. Department of Energy Report DOE/RW-0199, 9 volumes. 
M98004608

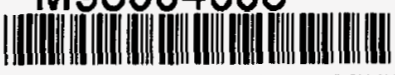

Report Number (14) य SGS-OIR--95-74

Publ. Date (11) $\frac{1995}{4 S G S, X F}$
Sponsor Code (18)
UC Category (19)

DOE 